Routledge Studies in Management, Organizations and Society

\title{
REPUTATION MANAGEMENT AND FAMILY BUSINESS
}

Zdzisława Dacko-Pikiewicz

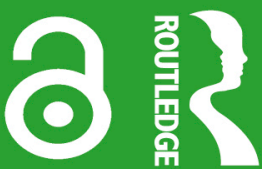




\section{Reputation Management and Family Business}

Corporate reputation is important in gaining long-term competitive advantage and building company value. Thus, the author points out the need to manage reputation, which, due to its complex nature and multidimensional character, is a serious and difficult challenge.

The author develops a strategic model for family business reputation management. The book presents the review, systematization and synthesis of views on the notion of reputation and its role in building company value, the determinants of reputation; the identification of the characteristics and distinguishing factors of family businesses, areas of reputation building and resources involved in family business reputation building processes; and the description of determinants, components and processes in the field of corporate reputation management, and the identification of key links between them. It also identifies the key elements of the concept of family business reputation management and the relationship between them and practical recommendations for the use of reputation management concepts in improving the functioning of family businesses.

The developed model can undoubtedly be seen as a pioneering contribution to research into the competitiveness of enterprises. The book will therefore be useful to researchers, students and managers who are interested in decision-making in family businesses, entrepreneurship and small business management, and leadership studies.

Zdzisława Dacko-Pikiewicz is professor of Applied Sciences and Rector at WSB University, Poland. 


\section{Routledge Studies in Management, Organizations and Society}

This series presents innovative work grounded in new realities, addressing issues crucial to an understanding of the contemporary world. This is the world of organized societies, where boundaries between formal and informal, public and private, local and global organizations have been displaced or have vanished, along with other nineteenth-century dichotomies and oppositions. Management, apart from becoming a specialized profession for a growing number of people, is an everyday activity for most members of modern societies.

Similarly, at the level of enquiry, culture and technology, and literature and economics, can no longer be conceived as isolated intellectual fields; conventional canons and established mainstreams are contested. Management, Organizations and Society addresses these contemporary dynamics of transformation in a manner that transcends disciplinary boundaries, with books that will appeal to researchers, students and practitioners alike.

Recent titles in this series include:

Pierre Bourdieu in Studies of Organization and Management Societal Change and Transforming Fields Sarah Robinson, Jette Ernst, Kristian Larsen, and Ole Jacob Thomassen

Self-Management, Entrepreneurial Culture, and Economy 4.0

A Contemporary Approach to Organizational Theory Development Agnieszka Rzepka, Zbigniew Olesiński, and Elżbieta Jędrych

Social Enterprise in China

Benedicte Brøgger

Reputation Management and Family Business

Zdzisława Dacko-Pikiewicz

Governance and Business Models for Sustainable Capitalism Atle Midttun 


\section{Reputation Management and Family Business}

\section{Zdzisława Dacko-Pikiewicz}


First published 2022

by Routledge

605 Third Avenue, New York, NY 10158

and by Routledge

2 Park Square, Milton Park, Abingdon, Oxon, OX14 4RN

Routledge is an imprint of the Taylor \& Francis Group, an informa business

(C) 2022 Zdzisława Dacko-Pikiewicz

The right of Zdzisława Dacko-Pikiewicz to be identified as author of this work has been asserted in accordance with sections 77 and 78 of the Copyright, Designs and Patents Act 1988.

The Open Access version of this book, available at www.taylorfrancis.com, has been made available under a Creative Commons Attribution-Non Commercial-No Derivatives 4.0 license.

Trademark notice: Product or corporate names may be trademarks or registered trademarks, and are used only for identification and explanation without intent to infringe.

Library of Congress Cataloguing-in-Publication Data

Names: Dacko-Pikiewicz, Zdzisława, author.

Title: Reputation management and family business / Zdzisława

Dacko-Pikiewicz.

Description: New York, NY : Routledge, 2022. I Series: Routledge studies in management, organizations and society I Includes bibliographical references and index.

Identifiers: LCCN 2021031489 (print) I LCCN 2021031490

(ebook) I ISBN 9781032127767 (hardback) I ISBN

9781032127798 (paperback) I ISBN 9781003226215 (ebook)

Subjects: LCSH: Family-owned business enterprises--

Management. I Reputation.

Classification: LCC HD62.25 .D33 2022 (print) I LCC HD62.25

(ebook) I DDC 338.7--dc23

LC record available at https://lccn.loc.gov/2021031489

LC ebook record available at https://lccn.loc.gov/2021031490

ISBN: 978-1-032-12776-7 (hbk)

ISBN: 978-1-032-12779-8 (pbk)

ISBN: 978-1-003-22621-5 (ebk)

DOI: $10.4324 / 9781003226215$

Typeset in Sabon

by MPS Limited, Dehradun 
To Martusia and Wojtek 


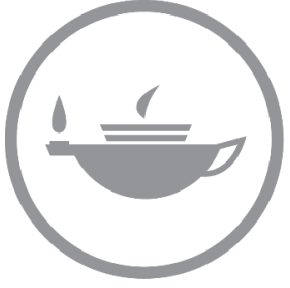

Taylor \& Francis Taylor \& Francis Group http://taylorandfrancis.com 


\section{Contents}

List of Tables

List of Figures

Funding Information

$\mathrm{X}$
$\mathrm{xii}$

About the Author

xiii

xiv

Introduction

1 Reputation - Importance to the Modern Organization

1.1 The Importance of Reputation in Enterprise Management 15

1.2 Corporate Identity in Terms of the Management Process 24

1.3 Image and Reputation - Interdependence of Concepts 31

1.4 Criteria and Determinants of Corporate Reputation 37

2 Areas which Determine the Reputation of Family Businesses

2.1 Nature of Family Businesses and Corporate Governance Mechanisms in Family Firms 52

2.2 Values as a Foundation for the Reputation of a Family Business 62

2.3 Relational Capital and Image of the Owner and Family as a Generator of Reputation-building Values 66

2.4 Building the Reputation of a Family Business on the Basis of the Concept of CSR 72 
viii Contents

2.5 The Issue of Succession and the Reputation of a Family Business 75

2.6 The Issue of Reputation in Internationalization of a Family Business 80

3 The Concept of Family Business Reputation Management

3.1 Principles of Reputation Management 95

3.2 Operationalization of Family Business Reputation Management 100

3.3 The Concept of Family Business Reputation Management 105

3.4 Stages of Family Business Reputation

Management 110

3.4.1 Importance of Value in Family Business

Reputation Management 110

3.4.2 Identification of Reputation-determining Areas 112

3.4.3 Reputation-building Strategy 119

3.4.4 Reputation Measurement 121

4 Family Business Reputation Management

4.1 Research Methodology 134

4.2 Experience of Selected Enterprises in Family

Business Reputation Management 140

4.2.1 Stakeholder Orientation 140

4.2.2 Knowledge of Factors which Influence

Reputation 151

4.2.3 Communication with Stakeholders 156

4.2.4 Reputation-building Strategy 162

4.3 The sustainability of Reputation Management in the Context of Intergenerational Change in the Opinion of Respondents 167

5 Evaluation, Conclusions and Recommendations for Family Business Reputation Management

5.1 Assessment of Family Business Reputation Management 174 
5.2 Theoretical Conclusions 203

5.3 Practical Recommendations for the Use of the Concept of Family Business Reputation Management 212

Conclusion 


\section{Tables}

1.1 Selected definitions of corporate reputation 18

1.2 Identity, image, reputation, brand - distinction of concepts

1.3 Criteria/determinants of the reputation rankings 39

2.1 Selected definitions of family businesses 54

2.2 Definitions of family business according to M.C. Shanker and J.H. Astrachan

2.3 Reputation as a factor of the internationalization of selected family businesses

3.1 Expectations and values of stakeholders 115

4.1 Core characteristics of the sample $(\mathrm{N}=300)$

4.2 Hierarchy of stakeholders of a family business taking the real impact of individual groups on the functioning and performance of the company into account respondents in total $(\mathrm{N}=300$, in \%)

4.3 Hierarchy of stakeholders of a family business taking the real impact of key groups on the functioning and performance of the company into account - respondents by selected characteristics ( $\mathrm{N}=300$, in \%)

4.4 Identification of expectations of key stakeholder groups about the respect for certain values shown by family businesses - opinions of respondents ( $\mathrm{N}=300$, in \%)

4.5 Criteria / determinants taken into account by stakeholders in assessing the reputation of a family business - opinions of the respondents $(\mathrm{N}=300$, in \%)

4.6 Eigenvalues and total explained variance 148

4.7 Rotated component matrix (varimax rotation) 149

4.8 Total explained variance (12 components) 150

4.9 Rotated component matrix (varimax rotation) 151

4.10 The concept of corporate reputation depending on the respondents' position $(\mathrm{N}=300$, in \%) 
4.11 Factors which influence the strengthening of the reputation of a family business - respondents' opinions $(\mathrm{N}=300$, in \%)

4.12 Communication activities of family businesses

4.13 Identification of threats to the reputation of a family business - respondents categorized by selected characteristics $(\mathrm{N}=300$, in \%)

4.14 Percentage of the market value of the family business which may be attributed to corporate reputation assessments of the respondents ( $\mathrm{N}=300$, in \%)

4.15 Benefits of a good reputation

5.1 Spearman's rank correlation coefficients: family and business values in family businesses and family business stakeholders

5.2 Spearman's rank correlation coefficients: values in family businesses and knowledge of the determinants of the assessment of the reputation of family businesses (part 1)

5.3 Spearman's rank correlation coefficients: values in family businesses and criteria/determinants taken into account in the assessment of the reputation of family businesses (part 2)

5.4 Spearman's rank correlation coefficients: family and business values in family businesses and the essence of the reputation of family businesses

5.5 Spearman's rank correlation coefficients: family and business values in family businesses and the characteristics of family businesses which strengthen reputation

5.6 Determinants of the value of reputation (Spearman's rank correlation coefficients)

5.7 Spearman's rank correlation coefficients: a definition of reputation and factors taken into account in its assessment

5.8 Spearman's rank correlation coefficients: the identification of factors which strengthen reputation and knowledge of factors taken into account in an assessment by stakeholders

5.9 Spearman's rank correlation coefficients: risk of loss of reputation and knowledge of factors which strengthen reputation

5.10 A reputation-building strategy in the family businesses $(\mathrm{N}=300$, in \%)

5.11 Spearman's rank correlation coefficients: the value of a family business and the value of reputation 


\section{Figures}

1.1 Factors shaping corporate identity 28

2.1 Family business system model 58

2.2 The charismatic image of the $\mathrm{CEO} /$ leader and the reputation of the family business $\quad 70$

3.1 Concept of family business reputation management 107

3.2 Classification of company valuation methods 123

4.1 The essence of reputation in the opinion of owners and successors

4.2 The benefits of good reputation - according to owners and successors

4.3 Family business value - declarations of owners and successors 


\section{Funding Information}

The project is funded under the program of the Minister of Science and Higher Education titled "Regional Initiative of Excellence" in 2019-2022, project number 018/RID/2018/19, the amount of funding PLN 10788423,16. 


\section{About the Author}

Zdzisława Dacko-Pikiewicz, Prof., Ph.D., Rector of the WSB University, Dąbrowa Górnicza since 2008. In addition to this function, she also holds the position of vice president of the Council of Chamber of Commerce and Industry in Katowice (since 2014) and chairwoman of the Commission for Competitiveness, Innovation and Cooperation between Science and Business (since 2015). She is the entrepreneurship ambassador successfully developing education strategy for business. For several years, she has been actively contributing to the development of cooperation between science and business sectors. She is also involved in the development of international cooperation by delivery of mobility, education and research. Professor Zdzisława DackoPikiewicz is committed to the social, cultural and economic development of the region through the promotion of science, knowledge, skills and competencies, increasing opportunities for formal and informal learning during lifetime. 


\section{Introduction}

The development and building of an organization's competitive advantages are related to the strategies it creates and implements to manage tangible and intangible resources, as well as its situation and relationships in the business environment. Companies use various approaches to increase their competitive advantages, which are largely based on intangible resources related to knowledge and relationships. Intangible assets such as corporate culture, brand, identity, image and reputation, and the capital of customer relationships - if properly designed and managed - increase company value. Being difficult to copy, they give a unique and distinctive character to the company and ensure the loyalty and commitment of key stakeholders. One such strategic intangible resource is reputation, which is the result of the company's relationship with various entities - interest groups. A large amount of research confirms the impact of a good reputation on building and strengthening customer loyalty, building an image of a valuable employer, attracting investors and facilitating cooperation with the best suppliers and contractors. These benefits translate into measurable results such as higher sales, lower marketing costs, lower capital costs, higher profits and higher growth potential (Szwajca, 2014; Cravens, Oliver, 2006; Fombrun, Gardberg, Sever, 2000; Beheshtifar, Korouki, 2013).

Reputation is a concept that appeared more widely in American literature in the 1990s, and nowadays it is considered from various perspectives, namely those of sociology, psychology, marketing, organization and management, finance and economics. Research on trust and reputation management is interdisciplinary, involving researchers from the areas of relationship building and communication, data and information systems management, e-commerce, artificial intelligence, game theory and economic and social sciences (Van Riel, Balmer, 1997). The perspective of a scientific discipline which is the starting point for research determines the semantic perception of this concept, e.g. reputation is attribute that signal the positively perceived behaviour of the company; corporate reputation as a barrier to market entry, a source of competitive advantage; reputation as intangible assets, a form of goodwill whose value fluctuates on the market;

DOI: $10.4324 / 9781003226215-101$ 


\section{Introduction}

reputation as perceptive assets capable of attracting loyal customers; reputation as a result of corporate identity, the crystallization of what a company is, how it functions and how it communicates with its stakeholders.

Corporate reputation is interpreted as (a) "awareness", (b) "assessment" and (c) "asset component". The first approach says that stakeholders are generally aware of the existence of a given company, but do not assess it. The second approach indicates that stakeholders are involved in one way or another in assessing the company's status. The third approach contains definitions related to the value and importance of corporate reputation as a resource or intangible, financial or economic value (Barnett, Jermier, Lafferty, 2006). Awareness (a) can be regarded as a variable that precedes reputation, while defining it as an asset (c) refers more to its consequences. Assessment (b), in turn, refers to the assessment of the status of the organization and is considered a more holistic approach. Recognizing reputation in terms of assessment rather than an asset also takes the idea that reputation can be positive, negative or neutral into account. Therefore, this work has adopted the meaning of reputation in relation to the overall assessment of the entity by stakeholders, sharing the view expressed, inter alia, by C.J. Fombrun, the President of the American Reputation Institute, who recognizes reputation as a common assessment of the organization's past actions and their effects, reflecting the organization's ability to generate valuable results from the point of view of stakeholders (Gołata, 2013).

Reputation is linked with the concepts of identity and image. Some researchers consider them to be convergent or identical, while others separate their meanings. To simplify, the concept of corporate reputation is identified with the prevailing opinion about the company. Reputation is external to the company (as opposed to identity) and includes an element of assessment (as opposed to image). Reputation is always of a social nature. Assessment refers to the extent to which the company is able to meet the expectations of its stakeholders in the future. Reputation is understood as the sum of subjective perceptions consisting of objective opinions, views and judgments, and reputation is therefore the sum of the partial corporate images accumulated over time. Therefore, the following relationship was adopted in the book: identity influences image, which in turn transforms into reputation, sharing the view expressed by K. Majchrzak (2009) and T. Dąbrowski (2010).

When analyzing the scope of the concept of reputation, it is also worth paying attention to its relationship with the concept of trust. According to M. Bojańczyk, there is a relationship between these concepts, because companies with a good reputation can be considered trustworthy (Bojańczyk, 2013). Furthermore, W. Rydzak (2011) analyzes models of the impact of reputation, trust and identification on customer behaviour.

Any discussion of corporate reputation means focusing one's attention 
on the company's behaviour towards stakeholders. Four main stakeholder groups participate in the process of building corporate reputation: employees, investors, customers and the community in which the company (organization) operates. According to A. Adamus-Matuszyńska, the value developed by all stakeholder groups creates corporate reputation. Opinion (assessment) mainly concerns the intangible and subjective assets of the company. For each stakeholder group, the company presents subjective value and generates measurable benefits. Company value as perceived by different stakeholder groups does not have to be convergent and identical.

The concept of reputation has been present in literature for only a few decades, which means that its significance and the scope of evaluation criteria are evolving, and its substantive content is affected by a rapidly changing socio-economic reality. The components of an assessment of a company by stakeholders which have an impact on the perception of its reputation include non-economic factors, i.e. those which are difficult to measure, and sometimes even immeasurable. The solid foundations of reputation are based on credibility, respect, trust, certainty about the company's future behaviour, respect, reliability and recognizability (Dąbrowski, 2010; Głuszek, 2015). Companies with a good reputation have visibility, transparency, individualism, cohesion (consistency) and authenticity (Dąbrowski, 2010).

Family businesses (Bertrand, Schoar, 2006) are a characteristic group of economic entities. They are characterized by the concentration of ownership, control and the maintenance of key positions in the management structure by family members even after the founders of the companies have resigned. This category includes both small economic entities and large family controlled enterprises. Family businesses are present in all sectors of the economy (Bell, 2002). They account for $65 \%$ to $90 \%$ of the total number of companies in the EU, the United States, Central and South America and Asia. They comprise approximately $70 \%$ of the workforce and produce on average between $40 \%$ and $70 \%$ of GDP; thus, they are one of the most important sources of wealth and employment growth in the modern world (Jeżak, 2016; Wach, 2014).

Family businesses combine business activities with the family sphere. Contemporary management conditions mean that family business managers face a number of strategic and operational management issues, as well as specific challenges arising from the circumstances and rules of family business. Problems pertaining, inter alia, to the development of corporate strategy, corporate culture and corporate social responsibility are related to the issues of succession, values and management by values and social family capital. The specificity of family businesses is that the owner's family shapes the company in a way that family members cannot do in non-family-owned businesses (Lansberg, 1983). It is the specific nature of family involvement in conducting business that makes family 


\section{Introduction}

businesses different from others, from which the need for research in this area arises. Features such as ownership, values, relationships and succession are distinguishing features of a family business (Boyd, Botero, Fediuk, 2014; Więcek-Janka, 2013).

The various areas of operation of the family business are related to the following values: values in family businesses are closely related to different areas of the company's operation; they are a "background" for organizational culture; they determine strategic planning, goal setting and the model of business management, determine the way of making decisions, implementing strategies and strategic alliances; they inspire the development and the achievement of best results; they are part of the recruitment and retention of employees (Aronoff, Ward, 2016); they are an element which integrates structures, processes and strategies to achieve maximum value (Martini, Suardana, Dwijendra, 2017); and they influence the choice of management. Family history creates company history - a coherent system of company value is one of the sources of success of family businesses. A family business, understood as a company-family-individual system, connects three areas. Values, feelings and intellectual processes that define the inner family world and the processes taking place within the organization are intertwined and interdependent. If their values are convergent and members of the subsystems act under similar rules in pursuit of objectives, synergies are created. It is emphasized that values in family businesses are also important when it comes to overcoming current crises, and in times of uncertainty they can ensure the continuity of decision-making. In a family business, the founder's values are crucial to its functioning and the consistency of its actions. His or her perception and interpretation of what the most important value brought into business is integrating all further actions. Owners significantly influence the company, following their personal goals and preferences in such a way that they are reflected in the company's objectives (Szczepańska-Woszczyna, Kurowska-Pysz, 2016; Tàpies, Fernández Moya, 2012). In conclusion, in the process of family business reputation management, family business-specific values should be taken into account at different levels and in all dimensions.

The variety of assessment criteria makes reputation an uneasy management subject. Reputation management refers to the overarching communication strategy adopted by the organization for adapting, combining, targeting and evaluating individual activities within the organization in terms of their potential impact on the organization's reputation. J. Low and P. Kalafut state that reputation is something completely elusive, amorphous, sensitive, very difficult or even impossible to control. The desired reputation cannot be built with advertising campaigns or PR activities, but through tangible things, such as good quality, solid partnerships, keeping commitments. Entities with a 
good reputation have achieved this because they manage their core business well, not necessarily their reputation itself (Dalton, 2011).

There seems to be no single universal management system for corporate reputation; however, its key elements can be identified, namely (1) constitutional relationships: defining stakeholder groups, the identification of behaviour towards their key stakeholder groups, developing standards according to which they design their practices vis-à-vis stakeholders; (2) reputation-building practices: business strategies and systems used to build reputation and relationships with key stakeholder groups; (3) organizational issues: the ways in which companies manage their reputation, having a "reputation-building strategy". It also includes the following processes: defining the identity and the need to express it by means of actions targeted at individual stakeholder groups; actions targeted at individual stakeholder groups which reflect the obligation to exceed standards at work and outside work; activities that companies take to convey their identity to key stakeholders and influence their perception; continuous "listening" to determine whether its message has been accepted and to reduce the gap between the perception of stakeholders and the perception of corporate identity (Fombrun, Rindova, 1998). Reputation is a multidisciplinary concept that, in order to be implemented in the long term, must be related to the company's fundamental strategies and objectives, its mission, values and vision.

In the case of family businesses, the owner's family forms an integral part of the company that influences corporate identity and image that is conveyed to the environment (Zellweger, Kellermanns, Eddleston, Memili, 2012). Since family businesses tend to have a long-term horizon of action and the owner's family strongly identifies with the business, the family strives to create a unique image and achieve a good reputation (Danes, Loy, Stafford, 2008; Zellweger, Nason, Nordqvist, Brush, 2013). Different rankings often assess family businesses on the basis of their reputation by presenting the best ones, which also confirms the importance of image and reputation. However, the importance of image and reputation is not limited to their influence on the company's success; they also affect related non-financial objectives such as social status and family interest (Dyer, Whetten, 2006).

The literature review conducted so far confirms that the issue of the reputation of family businesses is relatively poorly recognized. Over the last two decades, research on family business has developed significantly both in Poland and abroad, confirming the importance of this research area (research in this area has been conducted, inter alia, by J. Jeżak, J. Klimek, A. Lewandowska, A. Marjański, B. Nogalski, Ł.Sułkowski and K. Wach). Also, since the mid-1990s, the reputation and image of family businesses have been the subject of both theoretical and empirical studies, highlighting the growing interest in the subject. However, only narrow aspects of image and reputation were the subject of research, or 


\section{Introduction}

they were a sub-area of other research topics. The most frequently undertaken themes in this field included:

- the importance of the reputation of family businesses; differences between family and non-family businesses and their impact on reputation and image (Binz, Smit, 2013; Deephouse, Jaskiewicz, 2013; Erdem (2010); Gioia, Schultz, Corley, 2000);

- the reputation of family businesses from the perspective of customers (Beck, Kenning, 2015; Binz, Hair, Pieper, Baldauf, 2013; Orth, Green, 2009; Sageder, Duller, Mitter, 2015; Zellweger, Nason, 2008);

- the image and identity of family businesses (Craig, Dibrell, Davis, 2008; Krappe, Goutas, Von Schlippe, 2011; Micelotta, Raynard, 2011; Sageder, Mitter, Feldbauer-Durstmüller, 2018; Sundaramurthy, Kreiner, 2008; Zellweger, Eddleston, Kellermanns, 2010; Zellweger, Kellermanns, Eddleston, Memili, 2012);

- the impact of corporate social responsibility on the reputation of family businesses (Block, Wagner, 2014; Cruz, Larraza-Kintana, Garcés-Galdeano, Berrone, 2014; Du, 2015).

Similar conclusions are presented by Sageder, Mitter, FeldbauerDurstmüller (2018), ${ }^{1}$ who identify the themes of research into the image and reputation of family businesses limited to studying the essence and source of the reputation of family businesses, activities related to brand building and the loyalty of family business customers, financial and accounting aspects, and the role of the reputation of family business in investor relations, as well as the role of social responsibility in building the reputation of a family business. It can be noted that, despite the growing interest in the issue of the image and reputation of family businesses over the last decade, research in this area is still limited and fragmentary, and there is no overall picture of this research area.

In view of the above discussion, if reputation, both positive and negative, influences the enhanced competitive advantage of a company and the implementation of its development strategy, while there is no research on reputation management in family businesses, it is worth exploring the circumstances of the reputation management process and identifying the key elements of the process, taking into account the specificity of these businesses (the combination of family and business environments).

For a scientific problem defined as such, it is necessary to formulate research questions before the course of further research can be determined. These include the following questions: what factors determine the reputation of family businesses? What areas of operation of a family business are affected by its reputation? Which stakeholders of a family business have a real impact on the functioning and performance of the company? What types of strategies do family businesses use in building 
their reputation and relationships with key stakeholder groups? Is the reputation management strategy long-lasting in terms of the process of succession, or does the way of perceiving priorities in the process of reputation management change with successive generations? What communication activities are undertaken by family businesses to support building a good reputation? What values is the reputation of a family business correlated with? What are the key factors and elements of the reputation management process in family businesses?

In the context of the above-mentioned research questions, it is possible to identify a scientific problem, which is the lack of the concept of family business reputation management in organizational management theory, which takes into account the specificity of combining family and business environments, and which explains the determinants of the reputation management process and its key elements and improves the areas of the family business operation.

The main goal of the work is to develop a concept of family business reputation management. In order to ensure that this main objective is properly achieved, the following specific objectives have also been set:

- to present views on the understanding of the concept of reputation and its role in building company value, determinants of reputation, and the relationship to related concepts such as identity and image in light of the relevant literature, different approaches and research trends;

- to identify the characteristics and distinguishing features of family businesses, the areas of reputation building and resources employed in the processes of building the reputation of a family business, as well as key internal and external factors which strengthen/limit the reputation of a family business;

- to describe determinants, components and processes in the field of corporate reputation management, and to identify key links between them;

- to identify the key components of the concept of family business reputation management and their interrelationships;

- to develop theoretical conclusions and practical recommendations for the use of reputation management concepts in improving the functioning of family businesses.

The main hypothesis of the work is the supposition that there is a positive relationship between acting on the basis of the concept of family business reputation management and strengthening corporate reputation.

The main hypothesis is specified by defining the following subhypotheses: 1) The main areas of reputation building in a family business include the value of the family business, the company's stakeholder orientation, knowledge of factors affecting reputation, and reputation- 


\section{Introduction}

building strategy; 2) Family business values have a positive impact on the company's stakeholder orientation and the knowledge of factors affecting reputation; 3) The company's stakeholder orientation has a positive impact on the level/value of corporate reputation; 4) The knowledge of factors affecting reputation positively affects the level/ value of corporate reputation; 5) Differentiation of communication channels affects the individualization of access to different stakeholder groups; 6) Reputation-building strategies possessed and implemented are diversified and result from the company's stakeholder orientation, the knowledge of factors affecting reputation and knowledge of factors affecting the loss of reputation; 7) The reputation-building strategy has a positive impact on the level/value of corporate reputation; 8) The level of corporate reputation has a positive impact on the areas of activity of the family business.

Management sciences are part of empirical sciences (Lisiński, 2016), and can use both nomothetic and idiographic approaches, i.e. quantitative and qualitative research (Chełpa, 2004). The Grounded Theory ${ }^{2}$ method is inscribed in the nature of creating a theory in management, in which induction and qualitative research should be taken into account. The research process was based on the assumptions of this theory. A method of analysis and review of the literature and existing empirical studies was used to achieve the objectives. The first part consists of the review of national and foreign literature - the studies of publications on reputation, image, identity, stakeholder theory, family entrepreneurship, the examination of source documents (e.g. statistical data of the Central Statistical Office, Eurostat), and the analysis of cases described in the literature. The second part includes a review of existing research and the results of the authors' own research conducted by means of a survey method using survey questionnaires, based on the perception of family business representatives. Respondents in the survey conducted by means of computer-assisted telephone interviews (CATI) were owners, successors, members of supervisory boards or family businesses managers. These studies and analyses were the basis for building a model of family business reputation management.

The book is divided into five chapters. Chapter one presents views on the importance of reputation as a modern company resource, the origin of the perspectives in understanding and defining the concept of reputation, its "dimensions", depending on which science is the basis for a definition thereof, the process of shaping reputation, the relationship between reputation and related concepts such as identity and image their understanding and interrelationships, as well as criteria and determinants of corporate reputation assessment, including those used by organizations that rank companies operating in different markets due to their reputation. The risks associated with a loss of reputation and paradoxes associated with positive and negative reputation are also presented. 
Chapter two is an overview of potential areas for building the reputation of a family business. In the first part, the definitions of family businesses were organized and synthesized. The specificity of family businesses and their importance to the economy are presented. Criteria for distinguishing companies as family businesses and the consequences of their application are discussed. A family business cannot be defined based solely on objective criteria; subjective factors must be taken into account such as values and attitudes represented by the owner and his or her family, family commitment to running a business, and succession planning. The selected areas that determine the specificity of building the reputation of a family business are discussed in detail, including values, relational capital and the image of the owner/founder/leader, CSR activities and the importance of succession.

Chapter three is devoted to reputation management. A reputation management process is presented, in particular elements such as shaping corporate identity, identifying key stakeholder groups and stakeholder relationship management, communication and developing dialogue with stakeholders. The principles and stages of reputation management are discussed. The concept of reputation measurement is presented with examples of methods of its valuation.

In chapter four, which describes the concept of family business reputation management, the course of research and the methods and techniques used, as well as the methodological assumptions which they were based on, were indicated. It also includes the results of empirical research into the individual components of family business reputation management, including defining key stakeholder groups, identifying their expectations towards the company, defining the concept of reputation, the resulting benefits, the knowledge of factors that affect reputation and reputation risk, and having a reputation management strategy.

Chapter five presents the results of empirical research that includes the assessment of the relationship between the individual components of the family business reputation management process. In particular, correlations between the stakeholder orientation of family businesses, reputation orientation, the components of reputation management strategy and reputation value were studied. The context for these relationships was the features of family businesses, in particular their values, which are distinguishing features of family businesses and the starting point for family business reputation management. The succession process is also important for family business reputation management, as it can have both a positive and negative impact on corporate reputation and the further functioning of the company; hence, this element was also included as a determinant of actions related to building the reputation of a family business. The chapter ends with the presentation of conclusions and recommendations.

Given the complexity of the addressed issue, various theoretical, methodical and empirical aspects are presented mainly in the above 


\section{Introduction}

chapters, but some of them naturally penetrate into other parts. The theoretical elements are contained in three chapters; methodical elements relate mainly to the description of the research, the statistical measures used and the selection of research samples. Empirical elements, which complement the knowledge gathered in the theoretical chapters, are contained in chapters four and five. The purpose of their presentation is to analyze relationships between the various components of the reputation management process, taking into account the elements which constitute the context of these relationships.

\section{Notes}

1 Based on a review of literature on the state of research on the image and reputation of family businesses published until 2016. Among the 73 articles eligible for analysis (indexed in the Web of Knowledge, EBSCO, Elsevier, Emerald, Sage, and Wiley databases), 11 articles (published in marketing journals and communication-related journals) focus mainly on activities related to brand-building and the loyalty of family business customers; in eight articles, putting the emphasis on finance and accounting, the authors highlight the role of the reputation of a family business in investor relations, and in seven articles, the authors analyse the role of social responsibility in building the reputation of a family business. In the SCOPUS database (as of the end of March 2019) there are 28 publications that address the subject of reputation, and the issues of family businesses are included in 11 works.

2 Developed by B.G. Glaser and A.L. Strauss in 1967 and presented in the 1968 publication "Discovery of Grounded Theory: Strategies for Qualitative Research" (Glaser, Strauss, 2009). This concept assumes that the research process is based on building an increasingly general theory based on systematically collected empirical data (Glaser, Strauss, 2009). According to the authors, a theory can be formulated only after conducting empirical research, on the basis of which some assumptions are formulated, and verified in the course of further research. K. Konecki explains that building a theory according to this methodology is a process (Konecki, 2000, 26, cited after Ćwiklicki, 2010, 246-247).

\section{References}

Aronoff, C. and Ward, J. (2016). Family business values: How to assure a legacy of continuity and success. Berlin: Springer.

Barnett, M.L., Jermier, J.M. and Lafferty, B. (2006). Corporate reputation: The definitional landscape. Corporate Reputation Review, 9(1), pp. 26-38.

Beck, S. and Kenning, P. (2015). The influence of retailers' family firm image on new product acceptance: An empirical investigation in the German FMCG market. International Journal of Retail \& Distribution Management, 43(12), pp. 1126-1143.

Beheshtifar, M. and Korouki, A. (2013). Reputation: An important component of corporations' value. International Journal of Academic Research in Business and Social Sciences, 3(7), pp. 15-20. 
Bell, D. (2002). The break-up of family capitalism. In: C.E. Aronoff, J.H. Astrachan and J.L. Ward, ed., Family business sourcebook, 3rd ed. Georgia: Family Enterprise Publishers.

Bertrand, M. and Schoar, A. (2006). The role of family in family firms. The Journal of Economic Perspectives, 20(2), pp. 73-96.

Binz, C. and Smit, W. (2013). Sie sind ein familienunternehmen - Na und?!? Eine untersuchung des reputationalen effekts des status familienunternehmen. Betriebswirtschaftliche Forschung Und Praxis, 65(2), pp. 124-136.

Binz, C., Hair, J.F., Pieper, T.M. and Baldauf, A. (2013). Exploring the effect of distinct family firm reputation on consumers' preferences. Journal of Family Business Strategy, 4(1), pp. 3-11.

Block, J. and Wagner, M. (2014). Ownership versus management effects on corporate social responsibility concerns in large family and founder firms. Journal of Family Business Strategy, 5(4), pp. 339-346.

Bojańczyk, M. (2013). Niestabilna gospodarka, upadek zaufania i co dalej?[An unstable economy, a breakdown in trust - what happens next?]. Warszawa: Szkoła Główna Handlowa - Oficyna Wydawnicza, p. 14.

Boyd, B., Botero, I.C. and Fediuk, T.A. (2014). Incumbent decisions about succession transitions in family firms: A conceptual model. International Journal of Financial Studies, 2, pp. 335-358.

Chełpa, S. (2004). Indukcja i dedukcja w zarządzaniu - problem teorii i praktyki [Induction and deduction in management - the issue of theory and practice]. In: H. Jagoda and J. Lichtarski, ed., Nowe kierunki w zarzadzaniu przedsiębiorstwem - między teoria a praktyka [New trends in enterprise management - between theory and practice], 1st ed. Wrocław: Wydawnictwo Akademii Ekonomicznej im. Oskara Langego.

Craig, J.B., Dibrell, C. and Davis, P.S. (2008). Leveraging family-based brand identity to enhance firm competitiveness and performance in family businesses. Journal of Small Business Management, 46(3), pp. 351-371.

Cravens, K.S. and Oliver, E.G. (2006). Employees: The key link to corporate reputation management. Business Horizons, 49(4), pp. 293-302.

Cruz, C., Lazarra-Kintana, M., Garcés-Galdeano, L. and Berrone, P. (2014). Are family firms really more socially responsible? Entrepreneurship Theory and Practice, 38(6), pp. 1296-1316.

Ćwiklicki, M. (2010). Przesłanki stosowania teorii ugruntowanej w naukach o zarządzaniu [Prerequisites for the use of grounded theory in management sciences]. Acta Universitatis Lodziensis. Folia Oeconomica, 234, pp. 243-253.

Dalton, J. (2011). Reputations and strategic issue management. In: A. Hiles, ed., Reputation Management. Building and Protecting Your Company's Profile in a Digital World, 1st ed. London: Bloomsbury Information, pp. 203-216.

Danes, S.M., Loy, J.T. and Stafford, K. (2008). Business planning practices of family-owned firms within a quality framework. Journal of Small Business Management, 46, pp. 395-421.

Dąbrowski, T. (2010). Reputacja przedsiębiorstwa: tworzenie kapitału zaufania [Corporate reputation: the creation of trust capital]. Kraków: Wolters Kluwer Polska, pp. 72, 86. 


\section{Introduction}

Dąbrowski, T.J. (2010). Komunikacja kryzysowa jako narzędzie kształtowania reputacji [Crisis communication as a tool of establishing corporate reputation]. Marketing $i$ Rynek, 8, pp. 9-15.

Deephouse, D.L. and Jaskiewicz, P. (2013). Do family firms have better reputations than non-family firms? An integration of socioemotional wealth and social identity theories. Journal of Management Studies, 50(3), pp. 337-360.

$\mathrm{Du}, \mathrm{X}$. (2015). Is corporate philanthropy used as environmental misconduct dressing? Evidence from Chinese family-owned firms. Journal of Business Ethics, 129(2), pp. 341-361.

Dyer, W.G. and Whetten, D.A. (2006). Family firms and social responsibility: preliminary evidence from the S\&P 500. Entrepreneurship Theory and Practice, 30(6), pp. 785-802.

Erdem, F. (2010). Family business reputation: A literature review and some research questions. Electronic Journal of Family Business Studies (EJFBS), 4(2). Available at: https://www.jyu.fi/jsbe/en/entrepreneurship/ejfbs [Accessed 11 May 2019].

Fombrun, C.J. and Rindova, V. (1998). Reputation management in global 1000 firms: A benchmarking study. Corporate Reputation Review, 1(3), pp. 205-212.

Fombrun, C.J., Gardberg, N.A. and Sever, J.M. (2000). The Reputation Quotient SM: A multi-stakeholder measure of corporate reputation. The Journal of Brand Management, 7(4), pp. 241-255.

Gioia, D.A., Schulz, M. and Corley, K.G. (2000). Organizational identity, image and adaptive instability. The Academy of Management Review, 25(1), pp. 63-82.

Glaser, B.G. and Strauss, A.L. (2009). Odkrywanie teorii ugruntowanej: strategie badania jakościowego [Discovery of grounded theory: Strategies for Qualitative Research]. Kraków: Nomos.

Głuszek, E. (2015). Wielowymiarowość reputacji przedsiębiorstwa - czy rozgłos może być jednym z wymiarów? [The multidimensionality of corporate reputation-can publicity be one if dimensions?]. Management Forum, 3(2), pp. 30-37.

Gołata, K. (2013). Teoretyczne aspekty pojęcia reputacja [Theoretical Aspects of Reputation]. Studia Ekonomiczne, 157, pp. 185-193.

Jeżak, J. (2016). Rozwój przedsiębiorczości rodzinnej w Polsce na tle tendencji światowych [Development of Polish family firms in the context of global trends]. Przeglad Organizacji, 4, pp. 52-59.

Konecki, K. (2000). Studia z metodologii badań jakościowych [Studies in quality research methodology]. Warszawa: Wydawnictwo Naukowe PWN.

Krappe, A., Goutas, L. and Von Schlippe, A. (2011). The 'family business brand': An enquiry into the construction of the image of family businesses. Journal of Family Business Management, 1(1), pp. 37-46.

Lansberg, I.S. (1983). Managing human resources in family firms: The problem of institutional overlap. Organizational Dynamics, 12(1), pp. 39-49.

Lisiński, M. (2016). Metody naukowe w metodologii nauk o zarządzaniu [Scientific Methods in the methodology of management science]. Przeglad Organizacji, 4, pp. 11-19. 
Majchrzak, K. (2009). Zarządzanie reputacją korporacyjną we współczesnej gospodarce [Management of corporate reputation in the modern economy]. In: R. Maćkowska and H. Przybylski, eds., Public relations: aktualne zagadnienia sztuki komunikowania $w$ teorii i praktyce [Public relations: current issues of the art of communication in theory in practice], 1st ed. Katowice: Wydawnictwo Akademii Ekonomicznej im. Karola Adamieckiego, pp. 291-292.

Martini, L.K.B., Suardana, I.B.R., Dwijendra, N.K.A. (2017). Implementation of values on family company succession in Bali province. Indonesia. Journal of Sustainable Development, 10(4), pp. 75-82.

Micelotta, E. and Raynard, M. (2011). Concealing or revealing the family?: Corporate brand identity strategies in family firms. Family Business Review, 24(3), pp. 197-216.

Orth, U.R. and Green, M.T. (2009). Consumer loyalty to family versus nonfamily business: The roles of store image, trust and satisfaction. Journal of Retailing and Consumer Services, 16(4), pp. 248-259.

Rydzak, W. (2011). Reputacja a dziatania informacyjne organizacji w sytuacjach kryzysowych $i$ determinanty ich wyboru [Reputation and information activities of organizations in crisis situations and determinants of their selction]. Poznań: Wydawnictwo Uniwersytetu Ekonomicznego, pp. 20-24.

Sageder, M., Duller, C. and Mitter, C. (2015). Reputation of the family firms from customer perspective. International Journal of Business Research, 15(1), pp. 13-24.

Sageder, M., Mitter, C. and Feldbauer-Durstmüller, B. (2018). Image and reputation of family firms: A systematic literature review of the state of research. Review of Managerial Science, 12(1), pp. 335-377.

Sundaramurthy, C. and Kreiner, G.E. (2008). Governing by managing identity boundaries: the case of family businesses. Entrepreneurship Theory and Practice, 32(3), pp. 415-436.

Szczepańska-Woszczyna, K. and Kurowska-Pysz, J. (2016). Sustainable business development through leadership in SMEs. Economics and Management, 8(3), pp. 57-69.

Szwajca, D. (2014). Zarządzanie reputacją przedsiębiorstwa wobec sprzeczności oczekiwań interesariuszy [Corporate reputation management contrary to the expectations of stakeholders]. Studia Ekonomiczne, 202, pp. 90-99.

Tàpies, J. and Fernández Moya, M. (2012). Values and longevity in family business: Evidence from a cross-cultural analysis. Journal of Family Business Management, 2(2), pp. 130-146.

Van Riel, C.B.M. and Balmer., J.M.T. (1997). Corporate identity: The concept, its measurement and management. European Journal of Marketing, 31(5/6), pp. 340-355.

Wach, K. (2014). Familiness and born globals: Rapid internationalisation among polish family firms. Journal of Intercultural Management, 6(3), pp. 177-186.

Więcek-Janka, E. (2013). Wiodące wartości w zarządzaniu przedsiębiorstwami rodzinnymi [Leading values in family business management]. Poznań: Wydawnictwo Politechniki Poznańskiej.

Zellweger, T. and Nason, R. (2008). A stakeholder perspective to family firm performance. Family Business Review, 21(3), pp. 203-216. 


\section{Introduction}

Zellweger, T.M., Eddleston, K.A. and Kellermanns, F.W. (2010). Exploring the concept of familiness: Introducing family firm identity. Journal of Family Business Strategy, 1(1), pp. 54-63.

Zellweger T.M., Kellermanns, F., Eddleston, K.A. and Memili E. (2012). Building a family firm image: How family firms capitalize on their family ties. Journal of Family Business Strategy, 3(4), pp. 239-250.

Zellweger, T.M., Nason, R.S., Nordqvist, M. and Brush, C.G. (2013). Why do family firms strive for nonfinancial goals? An organizational identity perspective. Entrepreneurship Theory and Practice, 37(2), pp. 229-248. 


\section{Reputation - Importance to the Modern Organization}

\subsection{The Importance of Reputation in Enterprise Management}

The functioning of enterprises in the modern knowledge-based economy has influenced the revision of views on the scope of its activities and the structure of assets, both in material and financial terms, as well as assets not disclosed in the accounting system. Strategic intangible assets of the company include corporate image and reputation, the brand of the product, and customer relationships (Miśkiewicz, 2018, 34; Wójcik, 2009, 57-58). Building a market economy based on a new paradigm (knowledge, capital, land, production and globalization), in which knowledge and innovation play a crucial role, has become a challenge for companies that wish to achieve a high level of development and competitiveness. This new economy, also referred to as the digital economy or the network economy, has been reflected in research among economists, lawyers and sociologists, representatives of management sciences, but also practitioners of economic life (Toffler, 2003). The fact that the industrial and post-industrial eras clashed here is emphasized, as noted by B. Mikuła, A. Pietruszka-Ortyl, A. Potocka, and J. Chmiel et al., among others. Many authors imply that this has influenced transformations in the postcapitalist, digital, information society, the telematics society, and the knowledge-based society (Potocka, 2001; Drucker, 2009). Perceived through new technologies and products, supported by highly qualified labour resources, it determines the company's innovativeness and thus its modernity and the dynamics of development (Flaszewska, 2016).

In the modern knowledge-based economy, company market success is significantly affected by intangible resources, in particular in the form of intellectual capital, co-created by knowledge and information evolving towards innovation. The concept of an individual's intellectual capital comprises concepts such as brand capital, customer relationship capital, image and reputation capital, human capital or corporate culture capital. It is a valuable source of knowledge that allows for competitive advantage and development. This means that corporate image and 
reputation are perceived both by the economic and financial dimensions of its activities. They are difficult to evaluate and it is challenging to unambiguously demonstrate the measurable financial and non-financial benefits the company has achieved owing to them. It can therefore be said that both image and reputation are determinants that affect the development of a company.

In the analysis of the concept of reputation, its various "dimensions" and meanings are emphasized. A great number of economists, including Stigler (1962), Ross (1977), Stiglitz (2000), Weigelt and Camerer (1988), scientists involved in the field of accounting (e.g. K.E. Sveiby (1997)), strategic management (e.g. Wagner, Coley and Lindemann (2011), Caves and Porter (1977)) or sociology, including DiMaggio and Powell (1983), Shapiro (1987), Abrahamson and Fombrun (1994), among others, addressed the issue of reputation. In management sciences, reputation is identified with a resource that gives the company a competitive advantage and is an important barrier to entry; sociology pays attention to the interaction between the organization and stakeholders in the process of building reputation, while psychology pertains to the emotional element: positive and negative feelings, respect, trust, etc. The diversity and specificity of enterprise management processes mean that the concept of reputation takes on different meanings in different contexts, e.g. in strategic terms, reputation is the intangible resources of a company that are difficult to replicate and replace, but they create market barriers, which safeguard the company and build a competitive advantage ${ }^{1}$; they are an important factor which facilitates the company's expansion to new sectors, particularly where reputation can be transferred. In accounting terms, reputation co-creates company market value and is one of the intangible assets; in terms of marketing, reputation is a feature that defines stakeholder associations with a corporate brand. Despite the diversity of research and the concepts of reputation resulting from the diverse perspectives of different scientific fields, the need for an integrative view of corporate reputation is highlighted.

Researchers' discussions about what really shapes corporate reputation can be organized into two main trends:

- a trend which regards reputation as an aggregate assessment of certain attributes, resources and advantages of the organization, which enable it to produce good quality products (reputation as a result of the company's past activities, which thus signals its real features to stakeholders);

- a trend which equates reputation with an overall impression which represents the collective perception of the company by its stakeholders (reputation as a result of information exchange, social impact and interaction between different actors in the business environment). 
These two approaches to the discussion on how to build a good reputation can be viewed as an answer to the question of whether to be good (in what is done - which emphasizes the perceived quality of the company's specific attributes) or to be known (which emphasizes the collective awareness and perception that the organization has ensured in its environment). Importantly, from the point of view of the company, it is possible to treat both approaches not as competing with each other, but as two complementary dimensions of this phenomenon (to be good and known) (Głuszek, 2012). Lange, Lee and Dai (2011) describe three conceptualizations: being known, being known for something and generalized favorability.

Fombrun and Van Riel (1997) present reputation as an aggregate assessment of the company's past actions and future prospects based on the perception of various stakeholder groups (customers, employees, suppliers, local communities, financial institutions, investors, public administration, media and others) (Fombrun, Van Riel, 1997). J. Kouzes and B. Posner (1999) associate reputation with trust and security, thus expressing the view that reputation is linked to the past and provides a basis for credibility. The results of Post and Griffin's (1997) research into reputation can be expressed in the following words: "an aggregate assessment of the company's past actions and future prospects based on the perception of various stakeholder groups, including employees, customers, suppliers, investors and society", and therefore refers to the characteristics of the company. Balmer and Gray (2003) believe that reputation is created over time based on what the organization has done and how it has behaved. Dowlind (2016) points out that it is an overall evaluation, often expressed as admiration and respect. A generalized definition of reputation is also proposed by Baden-Fuller, Ravazzolo and Schweizer (2000). They understand it as an assessment of an organization's resources and capabilities by a clearly defined audience. In doing so, they pay particular attention to two important aspects of its shaping process. They regard reputation as one unmonolithic resource of the organization because it may be different with each audience and for different aspects of an organization. Furthermore, the phenomenon of reputational flow between individuals in an organization and even between different companies often occurs. The selected definition perceptions of reputation in literature and references which are relevant to the scientific problem dealt with herein, common in science and practice alike, are shown in Table 1.1.

In the early 20th century, especially in times of economic crisis, the role of corporate reputation was recognized both in theory and management practice as providing a reliable, stable assessment. Reputation is based on corporate identity, which in turn reflects its real characteristics. Its significance is particularly important for companies that operate in sectors where trust between contractors is of particular value. 


\section{Reputation}

Table 1.1 Selected definitions of corporate reputation

\begin{tabular}{|c|c|}
\hline Author & Definition of corporate reputation \\
\hline $\begin{array}{l}\text { J.M.T. Balmer, S.A. Greyser } \\
\text { C.J. Fombrun and M. } \\
\text { Shanley }\end{array}$ & $\begin{array}{l}\text { It represents the assessments of the company, } \\
\text { formed over time, based on what the } \\
\text { organization has done and how it has } \\
\text { behaved, carried out by entities surrounding } \\
\text { the organization. }\end{array}$ \\
\hline D.B. Bromley & $\begin{array}{l}\text { Corporate reputation reflects a firm's relative } \\
\text { standing, internally with employees and } \\
\text { externally with other stakeholders, in its } \\
\text { competitive and institutional environment. }\end{array}$ \\
\hline C.J. Fombrun & $\begin{array}{l}\text { Corporate reputation is a perceptual } \\
\text { representation of a company's past actions } \\
\text { and future prospects that describes the firm's } \\
\text { overall appeal to all of its key constituents } \\
\text { when compared with other leading rivals. }\end{array}$ \\
\hline $\begin{array}{l}\text { C.J. Fombrun, A.Gardberg, } \\
\text { J.M. Sever }\end{array}$ & $\begin{array}{l}\text { Corporate reputation is a collective construct } \\
\text { that describes. the aggregate perceptions of } \\
\text { multiple stakeholders about a company's } \\
\text { performance. }\end{array}$ \\
\hline M. Gotsi, M.A. Wilson & $\begin{array}{l}\text { Corporate reputation represents the overall } \\
\text { evaluation given by stakeholders. }\end{array}$ \\
\hline K. Saxton & $\begin{array}{l}\text { Reputation is the reflection of an organization } \\
\text { over time as seen through the eyes of its } \\
\text { stakebolders; expressed through their } \\
\text { thoughts and words. }\end{array}$ \\
\hline S.L. Wartick & $\begin{array}{l}\text { Corporate reputation is the aggregation of a } \\
\text { single stakeholder's perceptions of how well } \\
\text { organizational responses are meeting the } \\
\text { demands and expectations of many } \\
\text { organizational stakeholders. }\end{array}$ \\
\hline R. Wilson & $\begin{array}{l}\text { In common usage, reputation is a characteristic } \\
\text { or attribute ascribed to one person (firm, } \\
\text { industry, etc.) by another; Operationally, this } \\
\text { is usually represented as prediction about } \\
\text { likely future behavior. }\end{array}$ \\
\hline $\begin{array}{l}\text { E. Yoon, H.J. Guffey, } \\
\text { V. Kiev }\end{array}$ & $\begin{array}{l}\text { Corporate reputation reflects the history of its } \\
\text { recent activities and it affects the buyer's } \\
\text { expectations with regard to the quality of his } \\
\text { offer. }\end{array}$ \\
\hline
\end{tabular}

Source: Balmer and Greyser (2003); Fombrun and Shanley (1990); Bromley (2002); Fombrun (1996); Fombrun, Gardberg and Sever (2000); Gotsi and Wilson (2006); Saxton (1998); Wartick (1992); Wilson Roth 1985; Yoon, Guffey and Kijewski (1993)

For multinational companies, the loss of reputation means the risk of being unable to continue to operate in the market. The impact of corporate reputation on consumer purchasing decisions has been observed in mature markets for many years. As P.J. Firestein notes, it is a quantifier of the sustainable development of companies. At the same time, it is 
worth citing the opinion expressed by A. Figiel that reputation is one of the paradoxes of corporate life. Although no one disputes its importance, managers are much less focused on it than on other, more specific aspects of the activity. This is also confirmed by C.J. Fombrun and C. Van Riel, who stressed that although corporate reputations are ubiquitous in economic practice, they remain incomprehensible.

M. Barnett, J. Jermier and B. Lafferty attempted to organize and systemize the concept of reputation. Examining the issue, they concluded that it is shaped by awareness, assessment and assets. According to the authors, the first approach says that observers or stakeholders are generally aware of the existence of a given company, but do not assess it; what is important is "perception" - reputation has been defined as an aggregation of latent, networked and global perception, as well as knowledge and emotions that refer to the company because they point to its awareness. The second approach indicates that stakeholders are involved in the assessment of the company (they use concepts such as judgement, estimation, evaluation and assessment); the third one considers reputation to be valuable and important to the company as an intangible, financial or economic resource (though some authors consider it a consequence of reputation) (Barnett Barnett, Jermier, Lafferty, 2006). In a similar scientific narrative, A. Chodyński suggests that acceptance and trust, corporate identity and image combined with generally positive assessments constitute corporate reputation (Chodyński, 2008). It is influenced by the opinions of different stakeholder groups, including customers in particular. Based on research, K. Walker distinguishes the five most important attributes of reputation: (1) based on the perception of stakeholders, (2) a cumulative collective assessment of the organization, (3) relativism, (4) positive or negative character, and (5) relative sustainability and stability. Taking these values into account, he proposed a synthetic definition, which says that reputation is a relatively lasting result of an aggregated assessment of the company's past activities and prospects for its development based on certain standards (Walker, 2010).

In the literature on management, the concept of reputation (meaning respect, a positive opinion) is tantamount to assessing the company set against a background of the other companies which operate on the same market (Paliwoda-Matiolańska, 2009). According to the author, corporate reputation consists primarily of objective opinions, views and judgments of the external environment. It depends on credible actions, responsibility, fulfilment of promises, as well as ethical and open behaviour. It determines the state of trust or mistrust in a company and, as a result, is the sum of opinions of different recipients, and it affects the creation of market value. The value of reputation is an important factor, especially for service companies which operate based on knowledge, such as research and consulting agencies, banks, universities and design 


\section{Reputation}

companies. The products they offer are primarily purchased on the basis of trust, recognition and good opinion. In the definitions of reputation, attention is often paid to its judgmental and evaluating character, expressed, inter alia, as admiration, esteem and respect, but also the company's ability to satisfy stakeholders (fulfilling their expectations). Analyzing the knowledge-based economy and the companies operating therein, Dworak (2012) and Węgrzyn (2015) also indicate the important role played by factors/intangible resources in building competitive advantage in the context of reputation. Knowledge and innovation and intellectual capital are essential factors in determining the pace and quality of economic growth. Promoting innovation and the spread of information technologies, the mass use of information and communication technologies stimulate the competitiveness of the company and shape its reputation.

Reputation is understood as a valuable asset of a company. As such, it creates company goodwill and is included in its intangible assets. Based on the assessment of long-term financial, social and environmental impacts, it shapes the company's key competences. It is one of the unique competences of the company, identified with good reputation, positive image, repute and fame (Engelhardt, 2009). Today, reputation can be described as the aggregated opinions of business stakeholders about the company, based on the assessment of its broadly defined economic, organizational, social and environmental activity. Due to its complexity and multifacetedness, it is very difficult to manage. As a social category, which refers to knowledge, sensations, perceptions or beliefs arising in the minds of external observers and stakeholders, not fully comprehensible, not fully defined, and even delicate, fleeting, amorphous, very sensitive and easily damaged, is not fully controlled and shaped by the organization (Rindova, Williamson, Petkova, Sever, 2005; Low, Kalafut, 2002; Szwajca, 2018). The author also agrees that corporate reputation is shaped by many interdependent values such as reliability, credibility, solidity, security, openness, trust and responsibility.

Shaping reputation is a long-term and costly process. However, its completion in the form of success generates significant added value. Although reputation is part of intangible assets, it can in future generate tangible benefits not only for the company but also for employees, investors, stakeholders and even society. Reputation provides a basis for the acceptance of the company on the market; it influences its recognition, is an element of identification, enhances prestige and creates brand recognition. As D. Szwajca emphasizes, it often ensures market success and enables the company to survive in the long term (Engelhardt, 2009; Szwajca, 2017). The overview of the concepts of reputation shows the following aspects: 
- it is a set of attributes from the past, which characterize the organization;

- it is an evaluation of the attributes of the organization;

- it results from a rewarding experience with a given product or organization, and may be based on both personal experience and content resulting from the communication process;

- it constitutes an overall assessment of the company by stakeholders;

- it consists of objective knowledge and emotional elements of the individual;

- it is a snapshot that depicts different images accumulated over time;

- it reflects accumulated historical influences and possible experiences.

Reputation focuses on the assessment of external stakeholders, based on past actions and future prospects. This is an important aspect for the organization because it is often a prerequisite required by customers and consumers before they want to buy its products. The weak point of reputation measurement is the aggregation into one "image" of the various dimensions of the organization.

In conclusion, the definitions of reputation proposed in the literature can be grouped into three distinct groups, which include statements of similar importance. The first group defines reputation as "a state of consciousness" and refers mainly to perception (global, latent, individual, group and aggregate). Stakeholders are aware of the company's existence, they see it, but they do not assess it. Another cluster includes definitions that define reputation as "assessment", which imply that stakeholders assess the company. Researchers use terms such as assessment, estimation, evaluation, measurement, comparison, impressions and beliefs. The last cluster refers to definitions that regard reputation as "an asset of high value to a company". Intangible assets, economic assets, important assets, talented people, quality or a good financial condition are terms used by authors.

Taking the above approaches into account and in view of the discussion in this work, the meaning of reputation in relation to the overall assessment of the entity by stakeholders has been adopted, sharing the view expressed, inter alia, by C.J. Fombrun, the President of the American Reputation Institute, who recognizes reputation as a common assessment of the organization's past actions and their effects, reflecting the organization's ability to generate valuable results from the point of view of stakeholders (Gołata, 2013).

Since the 1990s, the relationship between the concept of reputation and the concepts of image and identity has been the subject of numerous scientific works. In fact, numerous researchers point out that company success depends largely on the coherence of all elements of corporate identity, image and reputation (Balmer, Greyser, 2002; Simoes, Dibb, Fisk, 2005).

P. Kotler and H. Barich stress that identity plays the main role in shaping reputation, as opposed to image, where communication plays a 


\section{Reputation}

Table 1.2 Identity, image, reputation, brand - distinction of concepts

\begin{tabular}{|c|c|c|c|}
\hline Concept & $\begin{array}{l}\text { Corporate } \\
\text { identity }\end{array}$ & Corporate image & Corporate reputation \\
\hline Key question & $\begin{array}{l}\text { Who are we as } \\
\text { an } \\
\text { organization? }\end{array}$ & $\begin{array}{l}\text { How does the } \\
\text { organization } \\
\text { want to be } \\
\text { perceived by } \\
\text { others? (required } \\
\text { image); What } \\
\text { does the } \\
\text { organization } \\
\text { think that others } \\
\text { think of it? } \\
\text { (anticipated } \\
\text { image) }\end{array}$ & $\begin{array}{l}\text { What do others really } \\
\text { think about the } \\
\text { organization? }\end{array}$ \\
\hline Essence & $\begin{array}{l}\text { The mind, soul } \\
\text { and voice of } \\
\text { the company } \\
\text { (Balmer, } \\
\text { Soenen, 1999) }\end{array}$ & $\begin{array}{l}\text { An image is not a } \\
\text { picture of what a } \\
\text { company is, it is } \\
\text { rather the feelings } \\
\text { and convictions } \\
\text { of the company in } \\
\text { the minds of its } \\
\text { recipients }\end{array}$ & $\begin{array}{l}\text { A common } \\
\text { assessment of the } \\
\text { organization's past } \\
\text { actions and their } \\
\text { effects, reflecting } \\
\text { the organization's } \\
\text { ability to generate } \\
\text { valuable results } \\
\text { from the point of } \\
\text { view of } \\
\text { stakeholders } \\
\text { (Fombrun, Van } \\
\text { Riel, 1997) }\end{array}$ \\
\hline Stakeholders & $\begin{array}{l}\text { Imagining, } \\
\text { perception of } \\
\text { internal } \\
\text { stakeholders }\end{array}$ & $\begin{array}{l}\text { Image, perception } \\
\text { of external } \\
\text { stakeholders }\end{array}$ & $\begin{array}{l}\text { Image, perception of } \\
\text { both internal and } \\
\text { external } \\
\text { stakeholders }\end{array}$ \\
\hline Dependence & & $\begin{array}{l}\text { May affect or be } \\
\text { affected by } \\
\text { reputation }\end{array}$ & $\begin{array}{l}\text { It is an umbrella } \\
\text { structure of which } \\
\text { the key elements } \\
\text { are image and } \\
\text { identity; may affect } \\
\text { or be affected by } \\
\text { image }\end{array}$ \\
\hline Experience & $\begin{array}{l}\text { Experience with } \\
\text { the company is } \\
\text { not necessary }\end{array}$ & $\begin{array}{l}\text { Experience with the } \\
\text { company is not } \\
\text { necessary }\end{array}$ & $\begin{array}{l}\text { In real terms, } \\
\text { reputation cannot } \\
\text { be assessed if there } \\
\text { is no experience } \\
\text { with the company } \\
\text { or its products and/ } \\
\text { or services }\end{array}$ \\
\hline Time & & $\begin{array}{l}\text { May change in the } \\
\text { short term }\end{array}$ & $\begin{array}{l}\text { It is built in the } \\
\text { long term }\end{array}$ \\
\hline Assessment & & $\begin{array}{l}\text { It can be both } \\
\text { positive and }\end{array}$ & $\begin{array}{l}\text { Can be both positive } \\
\text { and negative; it }\end{array}$ \\
\hline
\end{tabular}


Table 1.2 (Continued)

\begin{tabular}{|c|c|c|c|}
\hline Concept & $\begin{array}{l}\text { Corporate } \\
\text { identity }\end{array}$ & Corporate image & Corporate reputation \\
\hline & $\begin{array}{l}\text { It can be both } \\
\text { positive and } \\
\text { negative }\end{array}$ & $\begin{array}{l}\text { negative; it may } \\
\text { not reflect reality. }\end{array}$ & $\begin{array}{l}\text { reflects what is } \\
\text { currently known } \\
\text { about the } \\
\text { company; it is } \\
\text { stable and durable. }\end{array}$ \\
\hline
\end{tabular}

Source: own study based on: Wąsikiewicz-Firlej (2017); Gotsi and Wilson (2006); Wartick (2002); Chun (2005); Walker (2010); Radomir, Plăiaş and Nistor (2014).

major role (Kotler, Barich, 1991). The distinction between the concepts of identity, image and reputation is shown in Table 1.2.

It can be observed that stakeholders are an element that differentiates identity, image and reputation. Image is defined by reference to external stakeholders, while identity is defined by reference to internal stakeholders. Corporate image should be understood as a desirable image, which implies that external stakeholders create an idea of corporate image based on what is published from within the company. Consequently, the picture of the organization (desirable) can only be positive, as it is difficult to assume that the company would like to present a negative image to external stakeholders. Given that corporate image is "produced" within the company, it cannot be claimed that it faithfully reflects reality. Moreover, image is not as stable as reputation. Corporate identity, on the other hand, should reflect what a company really is, which means it can be both positive and negative. Reputation, like identity, reflects what is actually known about the company, whether it is positively or negatively perceived. However, unlike image and identity, reputation reflects what both internal and external stakeholders perceive and is built over a long period of time so that it can be considered stable and durable (Chun, 2005; Walker, 2010). Taking into account the differences in definitions and opinions of both scientists and practitioners, Alessandri (2001) proposed a model of the interdependence between reputation, image and identity. To simplify, the concept of corporate reputation is identified with the opinion about the company. Reputation is an external image of a company from the point of view of stakeholders (as opposed to identity expressing the real characteristics of the company) and contains an element of assessment (as opposed to image). It is the result of social interaction. Based on the effects of this interaction so far, assessment takes into account the extent to which the company will be able to fulfil the expectations of its stakeholders in the future. K. Gołata believes that reputation is more lasting than image. Image can change relatively quickly, as it is largely the result of organizational changes in a company or the modification of 


\section{Reputation}

communication processes. Reputation requires more time and consistency in the process of building it.

\subsection{Corporate Identity in Terms of the Management Process}

Identity is the answer to the question of "who am I?" (individual identity) or "who are we?" (collective identity). As such, it builds the image of an individual and a group in which it functions, and defines relationships between people and groups (Mach, 2008). The term corporate identity can be defined in an abstract or material way. The first group of terms metaphorically explains the understanding of identity. The second group, on the other hand, distinguishes three types of definitions. The first definition expresses a simplified understanding of identity as a visual expression of a company; the second links the essence of identity to corporate culture; and the third describes corporate identity holistically. A synthetic presentation of the definitions of corporate identity reveals it in the form of a set of values and real features of the company, expressed via the organizational mission, vision and culture, presented and transmitted through communication (marketing, direct, and a visual identification system) and behaviours to distinguish and build a competitive advantage of a company by creating its image, brand and reputation (Alessandri, 2001; Ashman, Winstanley, 2007; Balmer, Wilson, 1998; Blombäck, Brunninge, 2009; Holtzhausen, 2012). Transferred to the area of the organization in the 1980s, works by S. Albert and D.A. Whetten, the authors of the concept of organizational identity, initially associated the concept of identity with the participants' perception of certain organizational elements which they believe determine the sustainability of the organization while making the organization distinctive thanks to its relationships with the environment. They proposed a description by means of the following criteria:

1. a consensus between the members of the organization on what connects and differentiates them from other organizations;

2. time, i.e. the continuation and continuity of the transmission of differences and similarities;

3. belief in the validity of the criteria adopted in assessing what they have in common and what distinguishes them;

4. identification with the organization or company;

5. the functioning of a social group, i.e. independent of the notions of individual board members, owners, etc. (Stuart, Whetten, 1985; Sułkowski, 2005; Fryzeł, 2005).

Afterwards, assuming that an organization has an identity (subjective self and objective self), corporate identity was defined through the prism 
of distinctive attributes of an organization in relation to the environment, such as core values, organizational culture, competitive market behaviour or goods or services offered, or by referring to the participants' common understanding of distinctive, unique organizational values and characteristics (Elsbach, Kramer, 1996; Hatch, Schultz, 1997; Hatch, Schultz, 2004; Gabryś, 2015; Dutton, Dukerich, 1991; Konecki, Tobera, 2002). In this respect, the discussion on the relationship between the concepts of corporate identity and corporate culture is reflected. It may be observed that, in this sense, identity acts as a dependent variable and that culture is an independent variable. Identity is not static. On the contrary, it is active and dynamic, which is reflected in the process of organizational change (Strategor, 1999). Defining corporate identity as a "set of values and principles that employees and managers associate with the company", Fombrun (1996) limited the concept of identity to internal business stakeholders. According to C.J. Fombrun and C. Van Riel, corporate identity is defined by features which the employees believe to be of core importance (the identity should reflect their essence), which make the company stand apart from other organizations (employees must feel their company is distinct from other organizations, identify with the company and define the criteria of belonging and exclusion), which are permanent and which bring the present and past together with the future (Fombrun, Van Riel, 2004; Dacko-Pikiewicz, 2019). Davies, Chun, Da Silva and Roper (2001) and Barnett, Jarmier and Lafferty (2006) understood identity as an image seen by external stakeholders and recognized it as a basis for building corporate reputation. Gioia, Schulz and Corley (2000) extended their interpretation of corporate identity to include all stakeholders and considered it to include everything that is indigenous, characteristic and lasting for the organization. According to Gray and Balmer (1998), identity means the uniqueness of the organization and is integrated with its image, reputation and communication. Identity reflects and communicates the standardized patterns of conduct and communication patterns to the environment, which express the philosophy and essence of the institution. Its source is the complex personality of the organization, consisting of history, culture, management style and reputation. An inherent component is visual identity, understood as a kind of optical and aesthetic code, which enables the transmission of information (signals) which organizations care for most, i.e. those that build or consolidate its good image in the environment (Altkorn, 2004, 15; Black, 2003, 97). S. Black sees corporate identity in its complex personality, consisting of history, culture, management style and reputation (Black, 2003).

Research into corporate identity includes corporate identity, organizational identity and visual identity (Balmer, 2001). Corporate identity is an answer to the question "what are we?" in the context of questions about the company, its structure, strategy, ethos, market, activity, 


\section{Reputation}

history, reputation and relationships with other institutions. The concept of organizational identity and corporate personality, which can be considered very close to organizational identity, assumed a strategy for success that integrates all the company's activities around its personality, including subcultures in the organization, employee attitude to other organizational identities, cultural, industrial, sexual identity etc. (Hannebohn, Blocker, 1983; Whetten, Godfrey, 1998; Lis, 2013).

Identity can therefore be defined as a distinctive feature of the organization, which allows it to be recognized on the market and which employees identify with, and which is transferrable over time. This distinction is a collective interpretation of people who form an organization, which can relate to what an organization is and what it would like to be. The general nature of the definition is due to the ambiguity of the content behind the word "something". Its content is a consequence of the adopted research perspective for the scientific problem that is being solved here. It determines the scope of this concept, research subject and method. The selected definitions of identity are given below:

- a firm's unique capabilities (Ackerman, 1988);

- the reality of the corporation. It refers to the distinct characteristics of the organization (Gray and Balmer, 1998);

- something an organization can create, as well as control (Leicht, 1998);

- a set of attributes or characteristics which give the company a unique value in the opinion of different social groups. A deliberate composition of elements that identify the company, distinguishing it from others (Altkorn, 2004);

- planned visual elements that distinguish the company from others (Gregory and Weichmann, 1999);

- all visible and measurable elements, expressed in the company's visual presentation, containing the name, logo, slogan, colouring, decor and architecture (Alessandri, Alessandri, 2001, 2004);

- the way in which the company presents itself to internal or external recipients, embedded in the behaviour of the members of the organization (Van Riel, Balmer, 1997);

- a combination of strategies, behaviour, culture and communication concerning several disciplines, including but not limited to management, arising from the coherent philosophy of an organization (Balmer, Wilson, 1998).

It is worth noting that the term "corporate identity" goes together with other concepts, for example with organizational identity (identification), organizational personality, culture, symbolism or communication, as well as with strategy, organizational structure, image, brand and corporate reputation (Balmer, Greyser, 2002; Balmer, Olins, 2014; Balmer, 
Greyser, 2002; Dacin, Brown, 2002; Soni, Sharma, Upadhyaya, 2009; Zarębska, 2009). For the purpose of this work, with a view to the scientific problem to be solved, corporate identity has been characterized according to the taxonomy by T.C. Melewar and E. Karaosmangolu due to its multidimensional nature. The detailed distribution of factors that shape it is presented in Figure 1.1.

Corporate culture is the most developed and diverse category of corporate identity. Considering this fact, L. Sułkowski proposes the separation of paradigms in relation to the concept of corporate identity in the management sciences, which include:

1. a neopositive-functionalist-system paradigm which combines objectivity with regulation;

2. an interpretative-symbolical paradigm, which combines subjectivity with regulation;

3. postmodernism, which combines subjectivity with radical change (Sułkowski, 2012).

Corporate identity in functionalist terms is treated as a certain, objective, factual phenomenon in the organization. It can be discovered, described and measured by means of various mathematical models and complex measurements. But it can also be observed, modelled and managed. Its measurement should be quantified, and the best tool for this measurement is the quantitative method. Research on verifying company performance concerns the verification of its balance sheet, profit and loss accounts and cash flow statements. Various economic indicators and management accounting can also be used in this process. Interesting solutions in this respect, referring to the examination of company value, were recommended by Zarębska (2009), who pointed out that the Economic Value Added (EVA) indicator should be implemented to measure the results of corporate identity management (Zarębska, 2009; Grandys, 2011). Corporate identity in interpretative-symbolical terms focuses primarily on understanding how employees perceive themselves in an organization. The way a person perceives himself or herself in an organization depends on age, the experience, beliefs, views and values he/she presents. In the post-modernist approach to corporate identity, researchers focus on explaining how the organization's participants interpret social situations in which they play their organizational roles and the resulting value of emotions and attitudes. Relationships between the individual, group and community are analyzed, in particular how an individual overcomes social distortions and uncertainties which accompany the modernization and growth of civil society (Sułkowski, 2012; Denzin, Lincoln, 2010). The anthropological approach to corporate culture is also presented by Bratnicki, Kryś and Stachowicz (1988), who regard culture as sharing meanings and symbols, rituals and cognitive 


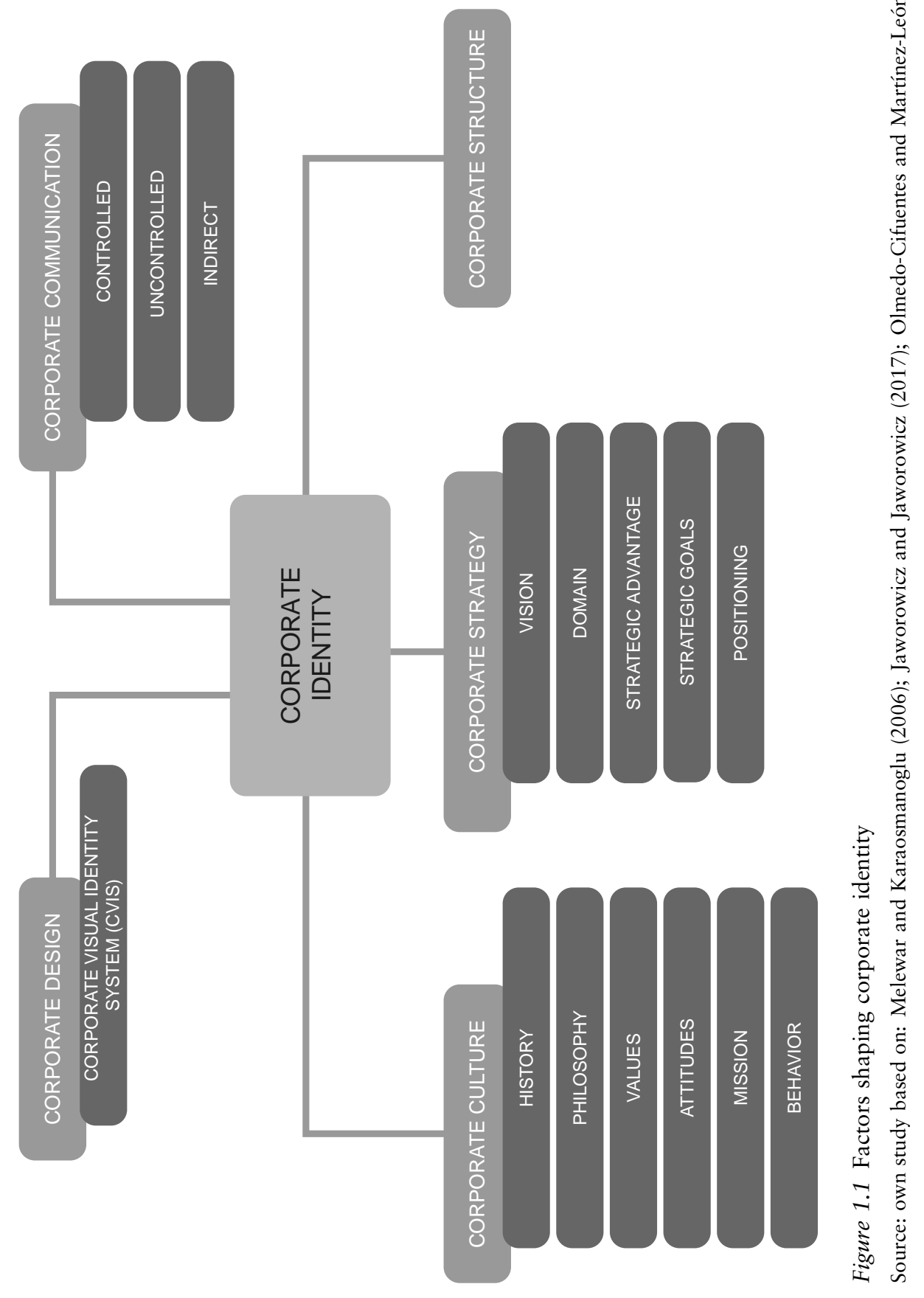


patterns, constantly formed and transformed as the organization tries to balance the requirements of maintaining internal consistency with the needs of responses detected in the environment (Pietkiewicz, Kałużny, 1993). Another definition is proposed by E. Schein: "Organizational culture is the pattern of basic assumptions that a given group has invented, discovered, or developed in learning to cope with its problems of external adaptation and internal integration" (Koźmiński, Piotrkowski, 1995).

Citing the results of research into corporate culture undertaken by many management classicists, L. Zbiegień-Maciąg draws conclusions closer to theoretical discussion on the definition of corporate culture, understanding it as norms and values, defining the specific behaviour of participants in a given organization, differing from others (ZbiegieńMaciąg, 1999; Sikorski, 1986). This way of perceiving organizational culture is represented by G. Hofstede, who understands it as collective mind programming, distinguishing members of one organization from another (Hofstede, 2000). Ordering and proposing the classification of organizational culture is found in C. Handy's scientific research. In his conclusions, it distinguishes four cultural orientations (rarely existing in pure form), which are, in fact, types of organizational culture, namely power, role, task, and person (Nogalski, 1998). The scientific conclusions of B. Nogalski and D. Foltyn (Nogalski, 1998) are also worth mentioning here. They believe that a company, which is a proponent of the culture of power, chooses one central decision-making centre, which gathers all powers to govern and subordinates executive centres. The structure in this form is reluctant to comply with external laws and any procedures; the power of the "leader" is the core of the organization (the death or departure of the boss often leads to the collapse of the company). The main motivation to work there is to achieve personal gains and a desire for power. On the other hand, the key concepts that can be used to characterize such an organization are power, victory and risk.

Literature on management sciences presents different definitions of the concept of identity, which, given the theoretical-methodical convention of this work, can be grouped according to at least three types of interpretation:

- strategic - i.e. the distinction of the company on the market;

- psycho-social - as an idea of oneself and an organization;

- marketing - the creation of profit resulting from distinction from competitors (Winch, 2011).

In the analysis of the above, different distributions of stress can be observed when separating the essential components of identity in the case of researchers and practitioners of economic life (Melewar, Jenkins, 2002). The scientific approach is more structure-oriented and takes more 


\section{Reputation}

identities into account. The approach adopted by practitioners places an emphasis on the process and focuses primarily on material (permanent) identity components, which often leads to a focus on visual aspects of identity. An overview of the literature in this respect can be summarized as follows:

Components of corporate identity:

- soul, mind, voice (Balmer and Soenen, 1999);

- personality, behaviour, communication, symbolism (Birkigt and Stadler, 1986);

- culture, behaviour, market conditions and strategies, products and services, communication and design (Schmidt, 1995);

- mind, spirit, body (Steidl and Emory, 1997).

According to Balmer and Soenen (1999), corporate identity consists of three basic components:

1. soul, understood as subjective components of corporate identity, including the values of employees, which are reflected in the multitude of subcultures, and a mix of different types of identification present in the organization (core values, cultures, internal images, "kinship" of employees, history) - values and identifications;

2. mind, i.e. the organization making informed decisions while pursuing its missions, visions and strategies (vision and philosophy, strategy, results in products and services, company performance, brand, the company's owner) - strategy and actions;

3. voice, which is various means of communication used within the company and for dialogue with external stakeholders (controlled communication, uncontrolled communication, symbolism, behaviour of employees and the company and indirect communication) - communication and a visual identification system.

Analyzing the functioning of the company and building its identity, the author identifies the following models of identity management in organization and management sciences and in other scientific disciplines:

- corporate identity management models according to J.M.T. Balmer, based on the ACID model (Hasanbegovic, 2011). The Balmer model distinguishes five types of corporate identity, namely actual identity, communication identity, conceived identity, ideal identity and desired identity; the AC2ID model develops the ACID model with C2 conceived identity, i.e. image, reputation. The AC2ID model was the basis for the development of two more AC3ID models - C3 covenanted identity and AC4ID - C4 cultural identity (Balmer, 
2001; Balmer, Greyser, 2002; Balmer, Gray, 2003; Balmer, Stuart, Greyser, 2009; Zarębska, 2003; Zarębska, 2006).

- strategic identity management models developed by N. Markwick and C. Fill and models with feedback from studies conducted between 1995 and 1998 by J.M.T. Balmer, E.R. Gray, N. Markwick and C. Fill. For example, the Balmer model (1995) describes the relationship between philosophy, mission, personality, identity, image and does not identify the areas of identity management (Markwick, Fill, 1997; Iyamabo, Owolawi, Otubanjo, Balogun, 2013; Gray, Balmer, 1998). In the model by $\mathrm{N}$. Markwick and C. Fill, the core element is corporate identity, which, through strategic management and management, marketing and organizational communication, provides the basis for creating the desired image (Markwick, Fill, 1997).

- the identity management model according to H. Stuart and the related models is a group of models based on H. Stuart's model (1999) which refers to the approaches by Dowling (1986), R. Abratt (1989), Van Riel and Balmer (1997), and Markwick and Fill (1997). The Stuart model presents communication as an image-shaping tool (Berniak-Woźny, 2011; Iyamabo, Owolawi, Otubanjo, Balogun, 2013; Markwick, Fill, 1997; Stuart, 1998; Stuart, 1999). It highlights the role of corporate strategy, recognizing it as a core element of management and the various forms of communication that play a role within the company and in relations with stakeholders (Stuart, 1999).

- the polymorphic model of corporate identity, according to Suvatjis, Chernatony and Halikias (2012), shows corporate identity management as a cyclic process whose core is nothing but identity. The process is composed of six components, namely the main factor (mission, vision, values, leadership, management), strategy (company brand, products and services, marketing), creativity (visual identity, visual identification system/symbolism, advertising), communication (traditional and digital channels within the company and in relation to the environment), human resources (employers and stakeholders) and a critical point (image, reputation, personality).

The above-mentioned discussion on corporate identity is an appropriate basis for analyzing the substantive links between image and reputation. This will be provided by the description of reputation, which fulfils the requirements of the modern organization.

\subsection{Image and Reputation - Interdependence of Concepts}

According to Gotsi and Wilson (2001), in the 1960s and 1980s, the image of companies was the subject of research, and the concept of 


\section{Reputation}

corporate reputation did not exist in wider scientific circles. Later, despite the growing interest in corporate reputation, numerous authors used the terms "image" and "reputation" alternatively, as the former gave a complete impression of the company (Dichter, 1985; Caruana, 1997). Diverse schools of thought developed, primarily in the United States and the United Kingdom, represented in three main trends, indicating that:

- corporate reputation and image are two separate, independent concepts;

- corporate reputation is a narrower concept than image and constitutes one of the dimensions of corporate image;

- corporate reputation can be shaped by many images (Gotsi, Wilson, 2006).

Today, image is regarded as an important intangible asset of the company, which significantly shapes its market value. It affects the company's position in the market and its ability to gain a competitive advantage. It is unique to any company and can be a source of future benefits. There are many interpretations and meanings in the relevant literature. For example, Sznajder (1993) notes that image is a subjective image of the company and its products. They may concern an industry, brand, and company. These images, as the author emphasizes, perform several functions; namely, they are:

- a carrier of the nature of the product and they determine the choice of brand by buyers;

- a sign of prestige - in addition to real benefits, there is added value associated with the purchase for product consumers and users;

- an element that differentiates products, brands and companies, and they are conducive to individualization;

- the basis for building trust in the company and a factor which reduces the risk of purchasing decisions by purchasers.

Corporate image is perceived similarly in economic sciences, where it is also identified with the image or opinion of the company and its products. W. Kroeber-Riel associates image with a multidimensional attitude, which is characterized by the following features:

- content - related to the subject of attitude and may concern an industry, company and products;

- direction - refers to a positive or negative stance to the subject of attitude;

- permanence - this is a stable feature, where change is only possible in the long term, and the range is related to the number of objects concerned (Biedermann, Urbaniak, 1998; Witczak, 1998). 
In J. Penc's research, the corporate image appears as a composition of corporate personality. This composition stems from its philosophy, history, culture, strategy, management style, reputation and the behaviour of employees and other representatives. The image so defined reflects the corporate personality that people perceive, identify with and express their own opinions and feelings (Penc, 1998). According to G.R. Dowling, image is a set of meanings based on which a given subject is known and by which people describe it, remember it and refer to it. He stresses that the main factor that influences corporate image is the experiences of its stakeholders arising from interaction with the company (Dowling, 1986). Budzyński (2002) believes that corporate image is its image in an environment that is largely influenced by a network of mutual contacts. It appears as a result of the characteristics of a given company, and at the same time it is associated with the experience and attitude of the people who it is addressed to. Therefore, it is not static, but changes with the company itself and its surroundings.

A corporate company is a subjective idea of a company. The positioning of the image in the minds of stakeholders and perceptions and feelings about the company affect its positioning compared to the competition. The pursuit of ideal self-image affects decisions taken by companies, which they often try to achieve by means of additional actions preferred at a given time. According to J. Altkorn, it precisely positions the company in the minds of the target audience, which is a significant source of competitive advantage and serves to gain public approval for its activities and to attract stakeholders. A strong image entails greater profits, less risk and stability in action. The value of the corporate image (quality of the image) influences the process of creating company goodwill, stimulating the demand for its products/services and profits (Altkorn, 2004).

In the 1990s, the concept of a knowledge-based economy was born, which has been understood as the next stage in the development of a market economy, and its essence is reduced to the ability to transform knowledge into innovation. It is an economy directly based on the generation, distribution and application of knowledge and information. The microeconomic approach presents companies as the main pillar of the knowledge-based economy. These companies base their competitive advantage on knowledge, and in macroeconomic terms it is an economy characterized by the rapid development of areas related to the processing of information and the development of science (Dworak, 2012). The literature on management sciences raises an important issue that a consequence of the intensification of competition processes is the fact that image-related actions adopt new functions. In addition to the traditional "marketing" corporate image, there is a need to create strong, positive associations in the awareness of current and potential employees. This means creating an image of a company as an employer. This allows for the acquisition of human resources with suitable 


\section{Reputation}

competences and intellectual potential, being aware of cooperation with a renowned organization.

Corporate image is shaped by both the economic and financial dimensions of company activity. Although it is difficult to evaluate and identify the measurable financial and non-financial benefits it has achieved and directly related to various assets and factors that change it, it undoubtedly constitutes an important determinant for company development. It affects its market value and position on the target market, is a factor in developing the confidence of financial markets, guarantees brand building (for the company and its products) and increases sales of products/services. It also ensures the achievement of revenues/profits and liquidity and enables the development of sustainable and effective relationships with stakeholders. It allows for greater stability and less risk, providing the opportunity to create alliances with attractive partners, attracts investors and facilitates access to capital. It significantly facilitates the acquisition of attractive (educated and experienced) employees and partners to cooperate with, creates better negotiating conditions with contractors, and contributes to the development of an innovative organizational structure and organizational culture (Miśkiewicz, 2019).

Image as an intangible asset of a company is not revealed directly in accounting terms because it is not subject to its rules (e.g. no specific classification criteria, valuation methods, presentation and disclosure rules). However, measures taken to build a sustainable image and its effects on certain parts of the company's functioning are indirectly presented in financial accounting and tax accounting (Bąk, 2016). The discussion shows that image in the financial sense is usually associated with the use of economic benefits (revenue) and expenditures (costs) that are revealed in financial accounting if they do not conflict with its overriding principles. On the other hand, in non-financial terms, image affects product/company brand, relationships with stakeholders, corporate/organizational culture and employee activity. Selected examples of the financial and non-financial benefits for the company arising from image and reputation are presented below:

- financial dimension - revealed in accounting: increased product sales revenues, higher profits, a satisfactory level of liquidity and working capital, rational cost management in terms of balance sheet and tax law, higher dividends for shareholders and higher salaries for employees. A well-thought-out and rational company policy with regard to processes: purchasing - finance - production - sales marketing, contributes to the creation of a non-financial (intangible) dimension;

- non-financial dimension - not revealed in accounting: building a strong product and company brand, creating proper and lasting relationships with customers and other stakeholder groups, 
acquiring knowledge for research and development, the implementation of new technologies, creation of identity (separateness and recognizability), observance and implementation of organizational culture (e.g. care for proper human behaviour, organization of work), development of human capital (quality and employee engagement in company activities). The examples affect the market value of the company and the achievement of competitive advantage.

Given the achievements of economic sciences and the contemporary understanding of the concept of image as an idea or opinion of a company and its products, and of progressive globalization and competition, an integrated image of the company is increasingly being discussed (Baruk, 2009). By adapting the definitions pertaining to both traditional marketing and image in management sciences, it can be assumed that integrated corporate image means an idea, conviction and feeling about a company, formed in the awareness of various actors, including external (market) stakeholders and internal (employee) stakeholders (Baruk, 2009; Dewalska-Opitek, 2010). Many authors point out that the contemporary integrated corporate image can be influenced by the following factors:

- the sphere of views and opinions relating to reasonable reasons for an assessment of the company by both external (individual and institutional) and internal customers;

- the sphere of the personality of an entity, expressed in emotional judgments and projections of market customers and employees;

- the social environment, including the social and cultural influences of the environment, which determine the behaviour of entities in the market (Biedermann, Urbaniak, 1998; Tkaczyk, Rachwalska, 1997; Budzyński, 2002; Baruk, 2009).

The literature review shows that the process of image creation is the subject of numerous research papers, analyses and publications by authors, who state that the integrated corporate image is built in accordance with the scenario: 1) identification of the image's audience, 2) identification of the desired image based on corporate personality and unique identity, 3) communication of the desired image to the audience, 4) identification of possible barriers and disruptions of the desired image, 5) image management over time.

Image is the picture of a given company which stakeholders have, while corporate reputation points to an assessment of the value of the company's attributes and usually evolves over time as a result of consistent action, enhanced by effective communication, while image can be created more quickly using well-thought-out communication programs. Companies want stakeholders to have positive views about them, which 
means that both image and reputation are important to the company. Key stakeholder groups include customers, distributors and retailers, suppliers, contractors, financial institutions and analysts, shareholders, public administration, the general public, the media and employees. In the opinion of these groups, corporate reputation will affect their willingness to provide or withhold support, which will affect the company's performance. Gray and Balmer (1998, pp. 695-696) proposed the model of the relationship between corporate image and corporate reputation. Identity is the reality of corporations. It refers to the different features of the organization, answering the following questions: What is an organization? What is the essence of the organization? Corporate identity management includes the dynamic interaction between the company's business strategy, the philosophy of its core managers, its organizational culture and visual identification. The result of the interaction between these elements is to distinguish the company from among others, creating its brand. Through organizational communication channels, the company presents its identity to recipients and/or stakeholders. It is the link between corporate identity and image and reputation, which are created in the perception of the audience. Image is a mental product of the perception of stakeholders - put simply, what comes to mind when someone hears or sees the name of the company or its logo. Reputation is a related concept. It means the assessment and evaluation of individual company areas, merging into corporate image.

In conclusion, image and reputation management fulfils two main objectives, the first of which is the creation of an "intended image" in the minds of the core audience. This means creating wide recognition of the company's name among target stakeholders, together with the immediate identification of the company's area of activity and its main products. The second goal is to create a good reputation in the minds of important stakeholders. The first goal is easier to achieve and may be done in a shorter timeframe. A strong image can be built through coordinated image campaigns, which accompany the core components of communication programs (name, logo, advertising, public relations etc.). Achieving a favourable reputation requires more than just communication activities, namely a substantive identity that can be built by continuous development over the years. On the other hand, communication programs can support this process and promote a positive reputation. It is possible that the company has a very good reputation, but it does not have as strong an image as its competitors. If the company plans to grow, a stronger image will be necessary.

The concept of corporate reputation and image is a bridge between the company and stakeholders. With their help, managers can test and communicate corporate strategy, challenges and goals. This perspective sees corporate reputation and image as a key strategic resource. The corporate identity of the company is communicated and transformed 
into corporate image in the eyes of stakeholders through a variety of communication mechanisms and channels. Over time, reputation attributes appear. The identification and communication system must be developed in order to maintain a recognizable corporate image and promote reputation. In today's dynamic and sensitive environment, strategic advantage and survival may depend on it.

\subsection{Criteria and Determinants of Corporate Reputation}

People create their beliefs about an organization based on their relationship with it and knowledge of its nature (including competitiveness, corporate culture), efficiency of resources, CEOs, employees, products and services (including their range, quality, value) and behaviour. This knowledge can be based on individual relationships with the organization, past behaviours, and other information which people communicate about the organization (Dowling (2004, p. 21). Beliefs and views consist of numerous sub-determinants. Typically, the list of determinants selected to describe an organization reflects areas that are crucial to a particular stakeholder group. For example, in its annual surveys of the most admired American companies, "Fortune" magazine measures beliefs about each company in relation to its financial condition, degree of innovation, the quality of products/services, its ability to develop and maintain key people, management quality, the use of assets, environmental friendliness and the value of investment.

The components of an assessment of a company by stakeholders which have an impact on the perception of its reputation include noneconomic factors, i.e. those which are difficult to measure, and sometimes even immeasurable. At the same time, the issue of the scope of the concept raises controversy among researchers. For example, are the company's attractiveness, corporate social responsibility or the number of companies which imitate a given company or its owner a component of the concept of corporate reputation? The fact that time plays an important role in building reputation should also be taken into account. The question arises: in what timeframe should corporate reputation be analyzed, and how to specify terms such as the past, the future, historical experiences, or crises in the past?

An interesting solution in this respect was proposed by T.J. Dąbrowski, who, after careful analysis of the sources, concluded that the solid foundations of a company's reputation are based on credibility, respect, trust, certainty about the company's future behaviour, esteem, reliability and recognizability (Dąbrowski, 2010; Głuszek, 2015). Similar comments have been made by researchers associated with the Reputation Institute, who imply that companies with a good reputation have visibility, transparency, individualism, cohesion (consistency), and authenticity (Dąbrowski, 2010). The determinants of reputation are defined in a 


\section{Reputation}

slightly different way by C.J. Fombrun, N. Gardberg, and J. Sever, who found it to be shaped by factors such as:

- emotional feelings - which determine how much respect or positive feelings a company evokes, etc.;

- products and services - an assessment of their quality, reliability and value;

- financial achievements - recognition of profitability, development opportunities and business risks;

- environment - sensing the atmosphere in the workplace, observing the approach to employees and managing the company;

- the scope of activity and an ability to lead - how clearly the company manifests its vision of action and leadership;

- the issue of social responsibility - assessing whether a company acts appropriately towards its shareholders, employees and the environment (Fombrun, Gardberg, Sever, 2000).

In the opinion of E. Głuszek, there is another group of factors that influence the way corporate image is formed and its reputation is built. This group consists of factors of the following nature:

- organizational: corporate culture, mission and vision of the company, a formal policy on strategy, structure and quality, customer service, and maintenance services;

- relative: they are based on the company's relationships with its stakeholders, by fulfilling the expectations of each party;

- marketing: ideas about the company and the products and services it offers, shaped by the use of different marketing instruments and the perceived quality of products/services;

- political: self-presentation of the company, assessments by the media, consumer associations, rating agencies, etc. (Głuszek, 2015).

According to R. Alsop, corporate reputation comprises financial performance, working conditions, the quality of products and services, governance and enterprise management, the vision and strategy pursued by the company, as well as the emotional bond between stakeholders and the company (Alsop, 2004). Many people erroneously identify reputation with corporate social responsibility and ethical behaviour. Ethics and social responsibility will certainly be of increasing importance, but such actions are only two elements on the map of factors which affect the perception of the company by stakeholders.

The concept of reputation has been present in literature for only a few decades, which means that its significance and the scope of evaluation criteria are evolving, and its substantive content is affected by the rapidly changing socio-economic reality. Table 1.3 lists reputation assessment 
Table 1.3 Criteria/determinants of the reputation rankings

\begin{tabular}{|c|c|}
\hline Assessor & Criterialdeterminants of the reputation rankings \\
\hline $\begin{array}{l}\text { "Manager Magazine" } \\
\text { German monthly } \\
\text { magazine, research into } \\
\text { the reputation of } \\
\text { domestic companies }\end{array}$ & $\begin{array}{l}\text { quality of management, innovation, corporate } \\
\text { social responsibility, product quality, } \\
\text { willingness to communicate with the } \\
\text { environment, financial and economic } \\
\text { stability, employee orientation, growth rate, } \\
\text { attractiveness of management and } \\
\text { internationalization of the company }\end{array}$ \\
\hline $\begin{array}{l}\text { "Fortune" American } \\
\text { economic magazine }\end{array}$ & $\begin{array}{l}\text { quality of products and services, quality of } \\
\text { management, innovation, social and } \\
\text { environmental responsibility, long-term } \\
\text { investment value (long-term willingness to } \\
\text { invest), reasonable use of company assets, } \\
\text { ability of employees }\end{array}$ \\
\hline $\begin{array}{l}\text { "Far East Economic } \\
\text { Review" Asian Economic } \\
\text { Magazine }\end{array}$ & $\begin{array}{l}\text { high quality of products or services, an } \\
\text { innovative approach to customer needs, long- } \\
\text { term vision of management, financial status of } \\
\text { the company and the number of companies } \\
\text { for whom the company's activities are worth } \\
\text { imitating }\end{array}$ \\
\hline $\begin{array}{l}\text { Edelman Trust Barometer } \\
\text { published annually } \\
\text { during the World } \\
\text { Economic Forum in } \\
\text { Davos }\end{array}$ & $\begin{array}{l}\text { high quality of products or services, corporate } \\
\text { social responsibility, innovation, transparency } \\
\text { and respect for business partners, trust, good } \\
\text { treatment of employees, constant } \\
\text { communication with the environment, fair } \\
\text { prices of products and services, the authority } \\
\text { of the President and financial performance of } \\
\text { the company }\end{array}$ \\
\hline $\begin{array}{l}\text { Harris-Fombrun } \\
\text { Reputation Quotient }\end{array}$ & $\begin{array}{l}20 \text { indicators of reputation divided into six } \\
\text { groups: emotional impressions (respect, } \\
\text { trust), quality and innovation of products and } \\
\text { services, financial and economic conditions, } \\
\text { company vision and quality of management, } \\
\text { attractiveness of the workplace and corporate } \\
\text { social responsibility }\end{array}$ \\
\hline $\begin{array}{l}\text { American Reputation } \\
\text { Institute }\end{array}$ & $\begin{array}{l}\text { brand confidence, value creation, degree of } \\
\text { consumer recognition and the nature of } \\
\text { emotion }\end{array}$ \\
\hline Other & $\begin{array}{l}\text { level of business risk, ownership structure, rate } \\
\text { of return on investment, relationships with } \\
\text { co-operators, attitude to competition, ethics } \\
\text { of activity and ethics of the behaviour of } \\
\text { board members and employees, the number of } \\
\text { articles on the company published in the } \\
\text { media, the relationship between positive and } \\
\text { negative media statements about the company } \\
\text { and the company's expenditure on } \\
\text { advertising, communication (intensity of the } \\
\text { process) and for social purposes }\end{array}$ \\
\hline
\end{tabular}

Source: own study based on Gołata (2013). 
criteria used by organizations which rank companies operating in different markets based on their reputation. As can be seen, many of the criteria are common to individual rankings, the others being individualized.

Corporate reputation has never been more valuable or more sensitive. Corporate abuse over the last few years in the United States has not only shown how valuable and fleeting reputation is, but also how one company's bad conduct destroys the entire industry. Companies with good reputations, despite their diversity, share common features such as a clearly defined set of values, which they follow in their actions, and consistency in observing them. They usually have a strong, distinctive brand, offer high-quality products and services, take socially responsible actions, and generate profits. Customer support is manifested in choosing their products or using their services, loyalty and recommendations. A good reputation is also an advantage in the staff recruitment process or in attracting potential contractors. It helps maintain the community's support and prevents activities which are unfavourable for the company.

As a result, companies with a good reputation achieve a stronger market position and better financial performance (Dąbrowski, 2010).

Building a positive reputation requires the company to provide evidence in the form of good quality and results, consistent and responsible behaviour, social responsibility, and fulfilling the expectations of stakeholders in the long term (Głuszek, 2016). The variety of assessment criteria mean that reputation is an uneasy management subject. J. Low and P. C. Kalafut state that reputation is something completely elusive, amorphous, sensitive, very difficult or even impossible to control (Kalafut, Low, 2001; Dalton, 2011; Gołata, 2013). The desired reputation cannot be built with advertising campaigns or PR activities, but through tangible things, such as good quality, solid partnerships, keeping commitments, etc. Entities with a good reputation have achieved this because they manage their core business well, not necessarily their reputation itself.

While financial performance, the quality of work, the quality of products and services, leadership and vision create a reputation, failure to comply with appropriate standards in these areas creates a bad reputation for the company. However, it is also worth paying attention to risk factors that create a bad reputation or the loss thereof. These include products/services (low quality, defectiveness, poor performance of services), working environment (poor working conditions, irregularities in hiring employees, delays in pay, accidents at work), social responsibility (non-compliance with the law, non-compliance with ethical standards, pollution of the environment), financial performance (lack of profitability, insolvency, failure to achieve financial objectives, loss of trust of contractors, suppliers), business relations and environment (illegal/unethical behaviour towards business partners, inappropriate response to 
crises). E. Głuszek highlights the lack of symmetry and different distribution of emphasis among the factors that build a good reputation and those that create a bad reputation or lead to a total loss thereof (Głuszek, 2014). While support for social initiatives is positively perceived and helps to build a good reputation, lack of support for such actions is unlikely to result in a bad reputation, but does not build a good reputation either. Another example is respect for workers' rights; because this is an obvious condition related to the activity of each company, it does not build a good reputation, yet failure to comply with labour law will certainly result in a bad reputation.

F. Partnoya shows the complex relationship between law and reputation and mentions six "shades of grey" (non-)observance of the law in the context of irresponsible corporate behaviour. Legal standards often define irresponsible behaviour in ambiguous ways.

A very good reputation can also have negative consequences in terms of a much stronger response from the media and stakeholders in the event of company crises and a reduction in the public acceptance of the organization. Research in this area has been conducted, inter alia, by V.P. Rindova, T.G. Rindova, Pollock and Hayward (2006), Pfarrer, Pollock and Rindova (2010), Zavyalova, Pfarrer, Reger and Shapiro (2012), and Zavyalova (2014). In addition, adverse events in highreputation organizations are more detrimental to social expectations than similar events in organizations without a good reputation. Renowned organizations are known not only to fulfil the expectations of stakeholders at a high level, but also to exceed them. Hence, adverse events in such organizations will be seen as unexpected and unacceptable.

The reputational paradox is that the improper conduct of competitors is in favour of a company which has lost its reputation as a result of abuse. If one company takes such action, it attracts disproportionate attention from the media and stakeholders, but if several other companies are involved in similar negative actions, each specific event is no longer a novelty and stakeholders pay less attention to one organization in particular (research by Ahmadjian, Robinson, 2001; Pfarrer, Pollock, Rindova, 2010). The direct adverse impact of irregularities on corporate reputation is lower when an organization's competitors are involved in similar offences. At the same time, crisis situations in competing companies are used by companies in a given industry that are not involved in similar situations to strengthen their reputation by publicly distancing themselves from such abuses.

Paradoxically, according to studies by authors such as Elsbach and Kramer (1996), Nag, Corley and Gioia (2007), and Kovoor-Misra (2009), adverse events in the organization do not always lead to reputational consequences, particularly in the case of high-reputation companies and stakeholders who strongly identify with the company. 


\section{Reputation}

Such a relationship can be a source of high self-esteem. When a situation threatens the corporate reputation, those who identify closely with it ignore it or present it in a different light, reformulate negative information, support and defend the organization to protect their personal identity. The responses of stakeholders to adverse events depend on corporate reputation and the level of identification with the organization. There is an elusive emotional bond between the company and its stakeholders, which is crucial to the sustainability of reputation.

The complexity, elusiveness, ambiguity and multifacetedness of approach and reputation assessment makes it a difficult research subject. The concept of reputation as a subject of research and management area has emerged in scientific discourse relatively recently. This interest was a natural consequence of a deeper reflection on corporate identity and image, which are discussed in this chapter. Definition-related disputes over the differences and convergence of concepts of identity, image and reputation lead to the conclusion that each of them cannot be discussed separately, in isolation from others. Their interrelationships do not allow for the selective treatment of each category of this triad. The success of the organization depends on the coherence of all components of identity, image and reputation. Given the relative stability and sustainability of reputation, it seems to be an easier research subject than image and identity. However, by making the subject of research a full idea of its level, based on the perceptions of internal and external stakeholders, it becomes a more complex research subject than the others.

In successful holistic approaches to various issues that broaden knowledge of the organization, reputation fits into one of the trends. It meets the assumptions of such an approach and, in a sense, organizes and explains disputes over highly dependent issues in similar areas. Research in recent years has enriched knowledge of the functioning of the organization, extending the range of reputation determinants to increasingly include new elements of formal and informal areas of companies. Easily measurable and rational phenomena include the sphere of emotions, feelings, imagination, ideas and relationships. Reputation is treated as a state of consciousness, an assessment of a state, or a resource of high value to a company. In this work, the importance of reputation refers to the overall assessment of activities and their value effects from the point of view of stakeholders. Its management should be part of the management of the entire organization and the conscious actions of all employees.

The multitude of divergent views and reputation assessments leads to a cautious conclusion about poor recognition of the phenomenon and opens the door to further research. 


\section{Note}

1 The challenge for activities related to reputation management are changes in conducting business caused by the development of the Internet and communication technologies, as well as the dynamics of today's environment, which make it easier for competitors to copy almost any position taken by a company on the market or to launch an effective attack on the position taken by the company in a very short time.

\section{References}

Abrahamson, E. and Fombrun, C.J. (1994). Macrocultures. Determinants and consequences. Academy of Management Review, 19(4), pp. 728-755.

Abratt, R. (1989). A new approach to the corporate image management process. Journal of Marketing Management, 5(1), pp. 63-76.

Ackerman, L.D. (1988). Identity strategy that make a difference. The Journal of Business Strategy, 5/6, pp. 28-32.

Ahmadjian, C.L. and Robinson, P. (2001). Safety in numbers: Downsizing and the deinstitutionalization of permanent employment in Japan. Administrative Science Quarterly, 46(4), pp. 622-654.

Alessandri, S.W. (2001). Modeling corporate identity: A concept explication and theoretical explanation. Corporate Communications: An International Journal, 6(4), pp. 173-182.

Alessandri S.W. and Alessandri T. (2004). Promoting and protecting corporate identity: The Importance of organizational and industry context. Corporate Reputation Review, 7(3), pp. 252-268.

Alsop, R.J. (2004). Corporate reputation: Anything but superficial - the deep but fragile nature of corporate reputation. Journal of Business Strategy, 25(6), pp. 21-29.

Altkorn J. (2004). Wizerunek firmy [Corporate image]. Dąbrowa Górnicza: Wyższa Szkoła Biznesu, pp. 15, 27.

Ashman, I. and Winstanley, D. (2007). For or against corporate identity? Personification and the problem of moral agency. Journal of Business Ethics, 76(1), pp. 83-95.

Baden-Fuller, C., Ravazzolo, F. and Schweizer, T. (2000). Making and measuring reputations. The research ranking of European Business School. Long Range Planning, 33(5), pp. 621-650.

Balmer, J.M.T. (2001). Corporate identity, corporate branding and corporate marketing: Seeing through the fog. European Journal of Marketing, 35(3/4), pp. 248-291.

Balmer, J.M.T. (2001). From the pentagon: A new identity framework. Corporate Reputation Review, 4(1), pp. 11-22.

Balmer, J.M.T. and Gray, E.R. (2003). Corporate brands: What are they? What of them?. European Journal of Marketing, 37(7/8), pp. 972-997.

Balmer, J.M.T. and Greyser, S.A. (2002). Managing the multiple identities of the corporation. California Management Review, 44(3), pp. 72-86.

Balmer, J.M.T. and Greyser, S.A. (2003). Revealing the corporation. London: Taylor and Francis, p. 177. 
Balmer, J.M.T. and Olins W. (2014). Corporate identity ascendancy and corporate brand hegemony. Celebrating the life of Wally Olins: Leading corporate identity exponent and prominent brand proponent. Journal of Brand Management, 21(6), p. 459-468.

Balmer, J.M.T. and Soenen, G.B. (1999). The acid test of corporate identity management ${ }^{\mathrm{TM}}$. Journal of Marketing Management, 15(1-3), pp. 69-92.

Balmer, J.M.T. and Wilson A. (1998). Corporate identity: There is more to it than meets the eye. International Studies of Management \& Organization, 28(3), pp. 12-31.

Balmer, J.M.T., Stuart, H. and Greyser, S.A. (2009). Aligning identity and strategy: Corporate branding At British Airways in the late 20th century. California Management Review, 51(3), pp. 6-23.

Barnett, L.M., Jarmier, J.M. and Lafferty, B.A. (2006). Corporate reputation: The definitiotal landscape. Corporate Reputation Review, 9(1), pp. 26-38.

Baruk, A.I. (2009). Rola wizerunku pracodawcy w funkcjonowaniu współczesnych przedsiębiorstw [The role of employer image in the functioning of contemporary enterprises]. Zarzadzanie Zasobami Ludzkimi, 6(71), pp. 11-24.

Bąk, M. (2016). Wizerunek i reputacja przedsiębiorstwa w gospodarce opartej na wiedzy z perspektywy rachunkowości [Corporate image and reputation in the knowledge-based economy from an accounting perspective]. Finanse, Rynki Finansowe, Ubezpieczenia, 2(80), pp. 11-20.

Berniak-Woźny, J. (2011). Tożsamość organizacji i modele zarządzania tożsamością organizacji [Organizational identity and models of organizational identity management]. Zarzadzanie Zmianami: Zeszyty Naukowe, 2(52), pp. 1-14.

Biedermann, M. and Urbaniak, M. (1998). Image - czynnikiem sukcesu firmy [Image as a factor in the success of a company]. Marketing $i$ Rynek, 5(11), pp. 17-19.

Birkigt, K. and Stadler, M.M. (1986). Corporate identity. Grundlagen, funktionen, fallbeispiele. [Corporate identity. Foundation, functions, case descriptions]. Landsberg am Lech: Verlag Moderne Industrie.

Black, S. (2003). Public relations. Kraków: Oficyna Ekonomiczna, p. 97.

Blombäck, A. and Brunninge, O. (2009). Corporate identity manifested through historical references. Corporate Communications: An International Journal, 14(4), pp. 404-419.

Bratnicki M., Kryś R. and Stachowicz D. (1988). Kultura organizacyjna przedsiębiorstw. Studium ksztaltowania procesu zmian $w$ zarzadzaniu [The corporate culture of enterprises. A study of shaping the process of change in management]. Wrocław: Zakład Narodowy im. Ossolińskich.

Bromley, D.B. (2002). Comparing corporate reputations: league tables, quotients, benchmarks, or case studies? Corporate Reputation Review, 5(1), p. 36

Budzyński, W. (2002). Wizerunek firmy: Kreowanie, zarzadzanie, efekty [Corporate image: creation, management, effects]. Warszawa: Poltext, pp. 13, 16-17.

Caruana, A. (1997). Corporate reputation: concept and measurement. Journal of Product and Brand Management, 6(2), pp. 109-118. 
Caves, R.E. and Porter, M.E. (1977). From entry barriers to mobility barriers: Conjectural decisions and contrived deterrence to new competition. The Quarterly Journal of Economics, 91(2), pp. 241-262.

Chodyński, A., ed. (2008). Zarządzanie rozwojem przedsiębiorstw i regionów [Management of the development of enterprises and regions]. Kraków: Krakowskie Towarzystwo Edukacyjne - Oficyna Wydawnicza, p. 45.

Chun, R. (2005). Corporate reputation: Meaning and measurement. International Journal of Management Reviews, 7(2), pp. 91-109.

Dacin, P.A. and Brown, T.J. (2002). Corporate identity and corporate associations: A framework for future research. Corporate Reputation Review, 5(2), pp. 254-263.

Dacko-Pikiewicz, Z. (2019). Values an element of family business identity. Intercathedra, 3(1), pp. 13-18.

Dalton, J. (2011). Reputations and strategic issue management. In: A. Hiles, ed., Reputation management. Building and protecting your company's profile in a digital world, 1st ed. London: Bloomsbury Information, pp. 203-216.

Davies G., Chun, R., Da Silva R.V. and Roper S. (2001). The personification the metaphor as a measurement approach for corporate reputation. Corporate Reputation Review, 4(2), p. 113.

Dąbrowski, T. (2010). Reputacja przedsiębiorstwa: tworzenie kapitału zaufania [Corporate reputation: the creation of trust capital]. Kraków: Wolters Kluwer Polska, pp. 10-11, 86.

Denzin, N.K. and Lincoln, Y.S., ed. (2010). Metody badań jakościowych [The Sage handbook of qualitative research]. Warszawa: Wydawnictwo Naukowe PWN, p. 35.

Dewalska-Opitek, A. (2010). Model kreowania zintegrowanego wizerunku przedsiębiorstwa [A model for creating an integrated corporate image]. Polityki Europejskie, Finanse i Marketing, 3(52), pp. 219-229.

Dichter, E. (1985). What's in an image?. Journal of Consumer Marketing, 2(1), pp. 75-81.

DiMaggio, P.J. and Powell, W.W. (1983). The iron cage revisited: Institutional isomorphism and collective rationality in organizational field. American Sociological Review, 48(2), pp. 147-160.

Dowling, G.R. (1986). Managing your corporate images. Industrial Marketing Management, 15(2), pp. 109-115.

Dowling, G.R. (2004). Corporate reputations: Should you compete on yours?. California Management Review, 46(3), p. 21.

Dowlind, G.R. (2016). Defining and measuring corporate reputations. European Management Review, 13(3), pp. 207-223.

Drucker, P. (2009). Menedżer skuteczny [An effective manager]. Warszawa: MT Biznes, pp. 13.

Dutton, J.E. and Dukerich, J.M. (1991). Keeping an eye on the mirror: Image and identity in organizational adaptation. Academy of Management Journal, 34(3), pp. 517-554.

Dworak, E. (2012). Gospodarka oparta na wiedzy w Polsce: ocena, uwarunkowania, perspektywy [Knowledge-based economy in Poland: assessment, determinants, perspectives]. Łódź: Wydawnictwo Uniwersytetu Łódzkiego, pp. 27-34. 
Elsbach, K. and Kramer, R. (1996). Members responses to organizational identity threats: Encountering and countering the Business Week rankings. Administrative Science Quarterly, 41(3), pp. 442-476.

Engelhardt, J., ed. (2009). Wspótczesne przedsiębiorstwo [The modern enterprise]. Warszawa: CeDeWu, pp. 74-75.

Flaszewska, S. (2016). Projektowanie organizacyjne $w$ zarzadzaniu wiedza [Organizational design in knowledge management]. Warszawa: Wydawnictwo Naukowe PWN Warszawa, p. 18.

Fombrun, C.J. (1996). Reputation: Realizing value from the corporate image. Boston: Harvard Business School Press.

Fombrun, C.J. and Van Riel, C. (1997). The reputational landscape. Corporate Reputation Review, 1(1/2), pp. 5-13.

Fombrun, C.J. and Van Riel, C.B.M. (2004). Fame and fortune: How successful companies build winning reputation. New York: Prentice Hall.

Fombrun, C.J., Gardberg, N.A. and Sever, J.M. (2000). The reputation quotient SM: A multi-stakeholder measure of corporate reputation. The Journal of Brand Management, 7(4), pp. 241-255.

Fombrun, C.J. and Shanley, M. (1990). What's in a name? Reputation building and corporate strategy, Academy of Management Journal, 33(2), pp. 233-258.

Fryzeł, B. (2005). Kultura korporacyjna: poglady, teorie, zarzadzanie [Corporate culture: views, theories, management]. Kraków: Wydawnictwo Uniwersytetu Jagiellońskiego, pp. 143-153.

Gabryś, B.J. (2015). Tożsamość organizacji w procesie odnowy organizacyjnej: ujecie narracyjne [Organizational identity in the process of organisational renewal: a narrative approach]. Management Forum, 3(2), pp. 25-29.

Gioia, D.A., Schulz, M. and Corley, K.G. (2000). Organizational identity, image and adaptive instability. The Academy of Management Review, 25(1), pp. 63-82.

Głuszek, E. (2012). Wpływ wizerunku lidera na reputację przedsiębiorstwa [The impact of the image of the leader on corporate reputation]. Prace Naukowe Uniwersytetu Ekonomicznego we Wroctawiu, 248, pp. 25-33.

Głuszek, E. (2014). Paradoksy dobrej i złej reputacji przedsiębiorstwa [Paradoxes of a good and bad corporate reputation]. Prace Naukowe Uniwersytetu Ekonomicznego we Wroctawiu, 422, pp. 109-121.

Głuszek, E. (2015). Wielowymiarowość reputacji przedsiębiorstwa - czy rozgłos może być jednym $\mathrm{z}$ wymiarów? [The multidimensionality of corporate reputation - can publicity be one of the dimensions?] Management Forum, 3(2), pp. 30-37.

Głuszek, E. (2016). Dobra i zła reputacja - jeden czy dwa wymiary? [Good and bad corporate reputation - one or two dimensions?]. Organizacja $i$ Kierowanie, 1, pp. 9-24.

Gołata, K. (2013). Teoretyczne aspekty pojęcia reputacja [Theoretical aspects of the concept of reputation]. Studia Ekonomiczne, 157, pp. 185-193.

Gotsi, M. and Wilson, A.M. (2001). Corporate reputation management: "living the brand". Management Decision, 39(2), pp. 99-104.

Gotsi, M. and Wilson, A.M. (2006). Corporate reputation: Seeking a definition. Corporate Communications: An International Journal, 6(1), pp. 24-30. 
Grandys, E. (2011). Teoria grafów w zarzadzaniu produkcja [Theory of graphs in production management], Warszawa: Polskie Wydawnictwo Ekonomiczne, p. 153.

Gray, E.R. and Balmer, J.M.T. (1998). Managing corporate image and corporate reputation. Long Range Planning, 31(5), pp. 695-702.

Gregory, J.R. and Weichmann, J.G. (1999). Marketing corporate image: The company as your number one product. Chicago: NTC Business Books.

Hannebohn, O. and Blocker, S. (1983). Corporate communication in the Praxis. Weberforum.

Hasanbegovic, D. (2011). Corporate reputation and brand architecture: The debate. The South East European Journal of Economics and Business, 6(2), pp. 37-45.

Hatch, M.J. and Schultz, M. (1997). Relations between organizational culture, identity and image. European Journal of Marketing, 31(5), pp. 356-365.

Hatch, M.J. and Schultz, M. (2004). The dynamics of organisational identity. In: M.J. Hatch and M. Schultz, eds., Organisational identity: A reader, 1st ed. Oxford-New York: Oxford University Press.

Hofstede, G. (2000). Kultury i organizacje: zaprogramowanie umystum [Cultures and organisations. Software of the mind] Warszawa: Polskie Wydawnictwo Ekonomiczne, p. 375.

Holtzhausen, L. (2012). Managing corporate identities of non-profit organizations in the social welfare sector. Jamba: Journal Of Disaster Risk Studies, 5(2), pp. 1-8.

Iyamabo, J., Owolawi, S., Otubanjo, O. and Balogun, T. (2013). Corporate identity: Identifying dominant elements in CI models. Journal of Management Research, 5(3), pp. 28-43.

Jaworowicz, M. and Jaworowicz, P. (2017). Skuteczna komunikacja w nowoczesnej organizacji [Effective communication in the modern organization]. Warszawa: Difin, p. 38

Kalafut, P.C. and Low, J. (2001). The value creation index: Quantifying intangible value. Strategy \& Leadership, 29(5), pp. 9-15.

Konecki, K. and Tobera, P., ed. (2002). Szkice z socjologii zarzadzania [Sketches from management sociology]. Łódź: Wydawnictwo Uniwersytetu Łódzkiego, p. 82.

Kotler, P. and Barich, H. (1991). A framework for marketing image management. Sloan Management Review, 32(2), pp. 94-104.

Kouzes, J.M. and Posner, B.Z. (1999). Wiarygodność [Credibility]. Skierniewice: CLK, p. 60.

Kovoor-Misra, S. (2009). Understanding perceived organizational identity during crisis and change a threat/opportunity framework. Journal of Organizational Change Management, 22(5), pp. 494-510.

Koźmiński, A. and Piotrkowski, W., ed. (1995). Zarzadzanie: Teoria i praktyka. Warszawa: Wydawnictwo Naukowe PWN, p. 302.

Lange, D., Lee P.M. and Dai Y. (2011). Organizational reputation: A review. Journal of Management, 37(1), pp. 153-184.

Leicth, K., ed. (1998). Research in social stratification and mobility. Greenwich, CT: JAI Press.

Lis, A. (2013). Zarządzanie tożsamością w organizacjach na różnych poziomach zagregowania [Identity management in organizations at different levels of aggregation]. Zarzadzanie i Finanse, 11(4)/2, pp. 205-219. 
Low, J. and Kalafut, P.C. (2002). Invisible advantage - How intangibles are driving business performance. Cambridge, MA: Perseus Publishing.

Mach, Z. (2008). Przedmowa. In: T. Paleczny, ed., Socjologia tożsamości [The sociology of identity], 1st ed. Kraków: Krakowskie Towarzystwo Edukacyjne - Oficyna Wydawnicza AFM, pp. 7-16.

Markwick, N. and Fill, C. (1997). Towards a framework for managing corporate identity. European Journal of Marketing, 31(5/6), pp. 396-409.

Melewar, T.C. and Jenkins, E. (2002). Defining the corporate identity concept. Corporate Reputation Review, 1(1), pp. 76-94.

Melewar, T.C. and Karaosmanoglu, E. (2006). Seven dimensions of corporate identity: A categorisation from the practitioners' perspectives. European Journal of Marketing, 40(7/8), p. 846-869

Miśkiewicz, R. (2018). Wiedza $w$ procesach konsolidacji przedsiębiorstw przemystowych. [Knowledge in the processes of consolidation of industrial enterprises]. Torun: TNOiK, pp. 34.

Miśkiewicz, R. (2019). Organisational structure in the process of integration on the example of iron and steel industry enterprises in Poland: Process digitisation in the Industry 4.0 concept. Warsaw: Wydawnictwo Naukowe PWN, p. 91.

Nag, R., Corley, K.G. and Gioia, D.A. (2007). The intersection of organizational identity, knowledge, and practice: Attempting strategic change via knowledge grafting. Academy of Management Journal, 50(4), pp. 821-847.

Nogalski, B. (1998). Kultura organizacyjna: Duch organizacji [Organizational culture: The spirit of the organization]. Bydgoszcz: Oficyna Wydawnicza Ośrodka Postępu Organizacyjnego, pp. 87, 124-127.

Olmedo-Cifuentes, I. and Martínez-León, I.M. (2014). Influence of management style on employee views of corporate reputation. Application to audit firms. $B R Q$ Business Research Quarterly, 17, p. 225.

Paliwoda-Matiolańska, A. (2009). Odpowiedzialność społeczna $w$ procesie zarzadzania przedsiębiorstwem [Social responsibility in the enterprise management process]. Warszawa: Wydawnictwo C.H. Beck, pp. 178-179.

Penc, J. (1998). Rynkowy wizerunek firmy [The image of a company on the market]. Marketing Serwis, 4, pp. 4-9.

Pfarrer, M.D., Pollock T.G. and Rindova, V.P. (2010). A tale of two assets: The effects of firm reputation and celebrity on earnings surprises and investors' reactions. Academy of Management Journal, 53(5), pp. 1131-1152.

Pietkiewicz, E. and Kałużny, S. (1993). Bankowcy i dobre obyczaje [Bankers and good practices]. Warszawa: Centrum Kreowania Liderów, p. 67.

Post, J. and Griffin, J. (1997). Part VII: Managing reputation: Pursuing everyday excellence: Corporate reputation and external affairs management. Corporate Reputation Review, 1(2), pp. 165-171.

Potocka, A. (2001). Wiedza - główny czynnik konkurencyjności przedsiębiorstwa [Knowledge - the main factor of enterprise competitiveness]. In: E. Urbańczyk, ed., Zarzadzanie wartościa przedsiębiorstwa w warunkach globalizacji [Value-based management in the conditions of globalization], 1st ed. Szczecin: Wydawnictwo Naukowe Uniwersytetu Szczecińskiego, p. 686. 
Radomir, L., Plăiaş, I. and Nistor, V.C. (2014). Corporate reputation, image and identity. Conceptual approaches. Marketing - From Information to Decision, 7, pp. 219-229.

Rindova, V.P., Pollock T.G. and Hayward, M.L.A. (2006). Celebrity firms: The social construction of market popularity. Academy of Management Review, 31(1), pp. 50-71.

Rindova, V.P., Williamson I.O., Petkova A.P., Sever J.M. (2005). Being good or being known: An empirical examination of the dimensions, antecedents, and consequences of organizational reputation. Academy of Management Journal, 48(6), pp. 1033-1049.

Ross, S.A. (1977). The determination of financial structure: The incentivesignalling approach. Bell Journal of Economics, 8(1), pp. 23-40.

Saxton, K. (1998). Where do reputations come from? Corporate Reputation Review, 1(4), p. 396.

Schmidt, C. (1995). The quest for identity. London: Cassell.

Shapiro, S.P. (1987). The social control of impersonal trust. American Journal of Sociology, 93(3), pp. 623-658.

Sikorski, C. (1986). Sztuka kierowania: szkice o kulturze organizacyjne [The art of management: Sketches on organizational culture]. Warszawa: Instytut Wydawniczy Związków Zawodowych, p. 16.

Simoes, C., Dibb, S. and Fisk, R.P. (2005). Managing corporate identity: an internal perspective. Journal of the Academy of Marketing Science, 33(2), pp. 153-168.

Stigler, G.J. (1962). Information in the labor market. Journal of Political Economy, 70(5), pp. 94-105.

Soni, S., Sharma, J.P. and Upadhyaya, M. (2009). Communicating corporate identity for the hotel industry. Journal of Marketing \& Communication, 4(3), pp. 53-58.

Steidl, P. and Emory, G. (1997). Corporate Image and Identity Strategies: Designing the Corporate Future. Warriewood, Australia: Business \& Professional Publishing.

Stiglitz, J.E. (2000). The contributions of the economics of information to twentieth century economics. The Quarterly Journal of Economics, 115(4), pp. 1441-1478.

Strategor. (1999). Zarzadzanie firma: strategie, struktury, decyzje, tożsamość [Company management. Strategies, structures, decisions, identity]. Warszawa: Polskie Wydawnictwo Ekonomiczne, p. 507.

Stuart, A. and Whetten D.A. (1985). Organizational identity. Research in Organizational Behavior, 7, pp. 263-295.

Stuart, H. (1998). Exploring the corporate identity/corporate image interface: An empirical study of accounting firms. Journal of Communication Management, 2(4), pp. 357-371.

Stuart, H. (1999). Towards a definitive model of the corporate identity management process. Corporate Communications: An International Journal, 4(4), pp. 200-207.

Sułkowski, Ł. (2005). Perspektywy rozumienia tożsamości organizacyjnej [Perspectives of the understanding of corporate identity]. Organizacja $i$ Kierowanie, 3, pp. 71-78. 


\section{Reputation}

Sułkowski, Ł. (2012). Epistemologia i metodologia zarzadzania [Epistemology and methodology of management]. Warszawa: Polskie Wydawnictwo Ekonomiczne, pp. 104-120.

Suvatjis, J., De Chernatony, L. and Halikias, L. (2012). Assessing the six-station corporate identity model: A polymorphic model. Journal of Product \& Brand Management, 21(3), pp. 153-166.

Sveiby, K.E. (1997). The intangible asset monitor. Journal of Human Resources Costing and Accounting, 2(1), pp. 73-97.

Sznajder, A. (1993). Sztuka promocji, czyli jak najlepiej zaprezentować siebie $i$ swoja firme [The art of promotion - how to best present yourself and your company]. Warszawa: Business Press, p. 174.

Szwajca, D. (2017). Kreowanie innowacji społecznych w kontekście budowania reputacji przedsiębiorstwa [The creation of social innovations in the context of building corporate reputation]. Zeszyty Naukowe Politechniki Ślaskiej, 114, p. 479.

Szwajca, D. (2018). Wielowymiarowy charakter reputacji przedsiębiorstwa implikacje dla zarządzania [The multidimensional nature of corporate reputation - implications for management]. Studia Ekonomiczne, 351, pp. $152-163$.

Tkaczyk, J. and Rachwalska, J. (1997). Wszystko jest obrazem. Kształtowanie wizerunku przedsiębiorstwa [Everything is an image. Shaping corporate image]. Marketing $i$ Rynek, 5, pp. 5-10.

Toffler, A. (2003). Zmiana władzy: wiedza, bogactwo i przemoc u progu XXI stulecia [Change of power: knowledge, wealth and violence at the turn of the 21st century]. Poznań: Zysk i S-ka, p. 72.

Van Riel, C.B.M. and Balmer, T. (1997). Corporate identity: The concept: It's measurement and management, European Journal of Marketing, 31(5-6), pp. 340-355.

Wagner, S.M., Coley, L.S. and Lindemann, S. (2011). Effects of suppliers' reputation on the future of buyer-supplier relationships: The mediating roles of outcome fairness and trust. Journal of Supply Chain Management, 47(2), pp. 29-48.

Walker, K. (2010). A systematic review of the corporate reputation literature: Definition, measurement, and theory. Corporate Reputation Review, 12(4), pp. 357-387.

Wartick, S.L. (2002). Measuring corporate reputation definition and data. Business \& Society, 41 (4), pp. 371-392.

Wartick, S.L. (1992). The relationship between intense media exposure and change in corporate reputation. Business \& Society, 31(1), p. 34.

Wąsikiewicz-Firlej, E. (2017). Tożsamość a wizerunek i reputacja przedsiębiorstwa na przykładzie koncernu Monsanto [Corporate identity and image and reputation: A case study of Monsanto]. Scripta Neophilologica Posnaniensia, 1509-4146(17), p. 571-585;

Weigelt, K. and Camerer, C. (1988). Reputation and corporate strategy. A Review of recent theory and applications. Strategic Management Journal, 9(5), pp. 443-454.

Węgrzyn, G. (2015). Innowacje $w$ sektorze ustug a zmiany strukturalne $w$ zatrudnieniu [Innovation in the services sector and structural changes in 
employment]. Wrocław: Wydawnictwo Uniwersytetu Ekonomicznego we Wrocławiu, p. 22.

Whetten, D.A. and Godfrey, P.C. (1998). Identity in Organisation. Thousand Oaks, CA: Sage Publications.

Wilson, R. (1985). Reputations in games and markets. In: A.E. Roth, ed., Gametheoretic models of bargaining, 1st ed. New York: Cambridge University Press, p. 27

Winch, S. (2011). Negocjacje i tożsamość jako wymiary typologii organizacji gospodarczych [Negotiations and identity as dimensions of the typology of economic organizations]. Organizacja i Kierowanie, 1, p. 146.

Witczak, I. (1998). Istota i strategia wizerunku firmy [The essence and strategy of corporate image]. Handel Wewnętrzny, 44(6), pp. 7-13.

Wójcik, K. (2009). Public relations. Wiarygodny dialog z otoczeniem. [Public Relations. A reliable dialogue with the environment]. Warszawa: Wydawnictwo Placet, pp. 57-58.

Yoon, E., Guffey, H.J. and Kijewski, V. (1993). The effects of information and company reputation on intentions to buy a service. Journal of Business Research, 27(3), p. 215.

Zarębska, A. (2003). Tożsamość przedsiębiorstwa - znacznie szersze spojrzenie na kulturę organizacyjną [Corporate identity - a much broader view of organizational culture]. Przeglad Organizacji, 1(756), pp. 14-16.

Zarębska, A. (2006). Zarządzanie tożsamością a zarządzanie przez tożsamość subtelna różnica czy milowy krok? [Identity management and management by identity - a subtle difference or a milestone?]. Przegląd Organizacji, 9, pp. 13-15.

Zarębska, A. (2009). Identyfikacja tożsamości organizacyjnej w zarzadzaniu przedsiębiorstwem [Identification of corporate identity in enterprise management]. Warszawa: Difin, pp. 23, 63.

Zavyalova, A. (2014). Negative consequences of good reputation and positive outcomes of negative events. Socio-Economic Review, 12(1), pp. 153-218.

Zavyalova, A., Pfarrer, M.D., Reger, R.K. and Shapiro, D. (2012). Managing the message: The effects of firm actions and industry spillovers on media coverage following wrongdoing. Academy of Management Journal, 55(5), pp. 1079-1101.

Zbiegień-Maciąg, L. (1999). Kultura $w$ organizacji. Identyfikacja kultur znanych firm [Culture in an organization. The identification of cultures of well-known companies]. Warszawa: Wydawnictwo Naukowe PWN, p. 14. 


\section{Areas which Determine the Reputation of Family Businesses}

\subsection{Nature of Family Businesses and Corporate Governance Mechanisms in Family Firms}

Family businesses are present in all sectors of the economy (Bell, 2002). They account for between $65 \%$ and $90 \%$ of the total number of companies in the United States, Central and South America and Asia, and around $70 \%$ on average in the EU, ranging from approximately $90 \%$ in Cyprus, Estonia, Spain, Germany and Italy, to approximately $35 \%$ in Latvia, Lithuania and Poland. They comprise approximately $70 \%$ of the workforce and produce on average between $40 \%$ and $70 \%$ of GDP; thus, they are one of the most important sources of wealth and employment growth in the modern world (Jeżak, Popczyk, WinnickaPopczyk, 2004; Wach, 2014). In the opinion of EU institutions, they play a positive role in terms of sources and opportunities for economic growth or as a remedy for crises (Klimek, Lipiec, 2015). The structure of family businesses in Poland is similar to that of all enterprises. The vast majority are microenterprises (approx. 80\%), small enterprises (approx. $10 \%$ ), medium-sized enterprises (approx. 8\%) and large enterprises $(2 \%)$. According to the statistics, depending on the definitions used, $90 \%$ of companies operating in Poland can be classified as family businesses (2015). Family businesses employ almost 1.5 million people (not including self-employed individuals) and produce almost $50 \%$ of GDP. The example of northern Italy shows that since the 1970s very small family businesses have often been concentrated in clusters, which have turned out to be important sources of innovation and competitive advantage (Colli, 2003). Family businesses were also the backbone of entrepreneurship and Chinese capitalism, which has transformed many Southeast and Eastern Asian economies over the past three decades (Redding, 1990). Their characteristic feature is heterogeneity, which on the one hand is typical of companies in the SME sector (Fernández, Nieto, 2005), but family businesses are also often large enterprises controlled by one family or several families, which further enhances the heterogeneity of this category of companies. One of the consequences of

DOI: $10.4324 / 9781003226215-2$ 
such diversity is definition-related problems - in research into family businesses there is no single universal definition (Table 2.1). They are not subject to separate legal regulations or a separate statistical category.

The analysis of the definition of family businesses, from the perspective of the scientific problem addressed here, allows for a conclusion which comprises some or all of the following characteristics: percentage of family ownership, percentage/number of family managers/employees, family controlling interest, multigenerational nature, family objectives and succession. However, many authors emphasize that these companies are characterized by a concentration of ownership, control and the maintenance of key positions in the management structure by family members even after the company founders have withdrawn. Numerous definitions determine the level of inclusion/exclusion and the percentage of ownership of companies that is in the hands of members of the same family (usually $50 \%$ to $100 \%$ ). Ł. Sułkowski confirms the lack of consensus on the criteria for distinguishing family businesses, while at the same time he points to the most common distinguishing features: the family ownership structure of the entity, the exercise of strategic control by the family, the participation of family members in management and the involvement of more than one generation of the family in the operation of the company. The most important criteria for recognizing an economic entity as a family business include ownership, management, family involvement in business and family succession (Sułkowski, 2004). E. Więcek-Janka and A. Lewandowska, taking up the challenge of classifying enterprises as family businesses, distinguished five levels with specific characteristics:

- Level 5 - Potentially family businesses. Ownership of the company is in the hands of the family (between $25.1 \%$ and $50.1 \%$ depending on the nature of ownership);

- Level 4 - Companies with family identity. They contain the features of Level 5 and self-recognition of the company as a family business (which is implied by business behaviour, including family values). At this level, the shaping of the identity of the family business begins;

- Level 3 - Single-generation family businesses. They contain the features of Level 4 and, in addition, involvement in the operational and strategic activity of a company by a minimum of one family member (not including the owner);

- Level 2 - Family businesses on the verge of succession. They contain the features of Level 3 and strategic planning in the company, taking the succession process into account. At least two family members are involved in day-to-day management and management activities with a specific intention of succession; 


\section{Reputation of Family Businesses}

Table 2.1 Selected definitions of family businesses

M. Bertrand and A.
Schoar (2006)
R. Beckhard and
W.J.Jr.Dyer (1983)

Jaffe (1990)

Tagiuri and

Davis (1996)

Donnelley (2002)

Sułkowski (2004)

European
Competitiveness
Report
$2008(2009)$

Polish Agency for Enterprise Development $(2000)^{1}$
Family businesses are characterized by the accumulation of ownership, control, and the maintenance of key management positions by family members even after the business founders have withdrawn

A family business is a whole consisting of interdependent subsystems of the company as a whole, family as a whole, founder and management.

An entity in which two or more family members share work and property.

An organization where two or more extended family members influence the direction of the business through the exercise of kinship ties, management roles or ownership rights.

Family businesses are those in which at least two generations of a family have had a mutual influence on company policy and on the interests and objectives of the family

A family business is an economic entity in which most of the ownership structure and the management function of the entity remain in the hands of one family.

A company, regardless of size, in which:

- the majority of the votes are held by the natural person(s) who has set up a company or has acquired shares in the company or in the possession of its spouse, parents, children or direct heirs of the children;

- majority votes may be direct or indirect;

- at least one family member or relative is involved in the management or administration of the company; and in the case of listed companies, the company is referred to as a family business if a family has established or acquired shares in the company or its descendants hold $25 \%$ of the voting rights arising from the capital held.

A family business is any economic entity in the sector of micro, small or medium-sized enterprises, of any legal form, registered and operating in Poland, in which:

1. at least two family members work together in that company,

2. at least one family member has a significant impact on management,

3. family members hold a significant or majority shareholding in the enterprise.

1 The Polish Agency for Enterprise Development (PAED) is a governmental agency reporting to the Minister of Economy. It was established under the Act of 9 November 2000.

Source: Final report of the expert group: European Competitiveness Report 2008 (2009); Jaffe (1990); Tagiuri and Davis (1996); Bertrand and Schoar (2006); Donnelley (2002); Beckhard and Dyer (1983); Sułkowski (2004); Kowalewska (ed.) (2010); European Competitiveness Report 2008 (2009) 
- Level 1 - Multigenerational family businesses. They contain the features of Level 2 and succession (Więcek-Janka, Lewandowska, 2017).

The features of family businesses include the interdependence of the owner's family with the family business (participation of the family in ownership and management of the company), the pursuit of family ownership and/or authority transfer, family organizational culture and the link between family and business objectives in corporate strategy.

The above findings, pertaining to the definition of the family business category, are important in terms of the results of research into this group of companies, comparing their activities or the functioning of family and non-family businesses, and that was also the premise of their analysis. According to research by M.C. Shanker and J.H. Astrachan, depending on the criteria adopted for defining family businesses (broad, middle and narrow perspectives), in the US, the number of family-owned businesses varies from 4.1 million to 20.3 million (Shanker, Astrachan, 1996) (the differentiation of perspectives according to M.C. Shanker and J.H. Astrachan is presented in Table 2.2).

The accumulation of ownership and power in a dimension such as in a family business has many positive aspects; according to Jeżak (2016), they include:

Table 2.2 Definitions of family business according to M.C. Shanker and J.H. Astrachan

\begin{tabular}{|c|c|c|c|}
\hline Criterion & $\begin{array}{l}\text { Broad } \\
\text { definition }\end{array}$ & $\begin{array}{l}\text { Middle } \\
\text { definition }\end{array}$ & Narrow definition \\
\hline Ownership structure & $\begin{array}{l}\text { Significant } \\
\text { family } \\
\text { shares }\end{array}$ & $\begin{array}{l}\text { Controlling } \\
\text { family shares }\end{array}$ & $\begin{array}{l}\text { Majority family } \\
\text { shares }\end{array}$ \\
\hline $\begin{array}{l}\text { Strategic and } \\
\text { management } \\
\text { control }\end{array}$ & $\begin{array}{c}\text { Minimum } \\
\text { strategic } \\
\text { control }\end{array}$ & $\begin{array}{l}\text { Strategic control } \\
\text { and } \\
\text { involvement } \\
\text { in } \\
\text { management }\end{array}$ & $\begin{array}{l}\text { Strategic control and } \\
\text { full management }\end{array}$ \\
\hline $\begin{array}{l}\text { Intergenerational } \\
\text { structure }\end{array}$ & Not required & $\begin{array}{l}\text { Anticipated } \\
\text { family } \\
\text { succession }\end{array}$ & $\begin{array}{l}\text { Multigenerational } \\
\text { entity }\end{array}$ \\
\hline $\begin{array}{l}\text { Involvement of } \\
\text { family members }\end{array}$ & Low & Moderate & High \\
\hline $\begin{array}{l}\text { Percentage of GDP } \\
\text { generated in } \\
\text { the USA }\end{array}$ & $49 \%$ & $30 \%$ & $12 \%$ \\
\hline $\begin{array}{l}\text { Employment in } \\
\text { the USA }\end{array}$ & $59 \%$ & $37 \%$ & $15 \%$ \\
\hline
\end{tabular}

Source: own study based on Shanker and Astrachan (1996). 
- much greater propensity to reinvest assets in order to multiply and maintain them for future generations than in non-family businesses;

- the long-term prospect of functioning and benefits (owners do not want quick profits at all costs and not at the cost of the company's existence);

- a lot of caution in undertaking risky investment projects, ensuring the financial security of the family;

- a high level of resistance to a downturn (in times of crisis, family members are able to make great sacrifices);

- care about the quality of products or services, related to the fear of losing the prestige of the family name (corporate brand), among other things;

- strong strategic orientation of activities;

- decreased tendency to reduce employment in crisis periods;

- increased inclination and readiness to act for the benefit of local communities. One in five large American, Canadian or French corporations is controlled by families. Despite low survival rates after the third generation, many family businesses have become global companies. The German company Bosch, founded by Robert Bosch in a small workshop and employing only two people at the time (1886), is today an international company with around 300,000 employees and manufacturing facilities worldwide. Today, the Bosch Group is one of the global largest suppliers of automotive parts, as well as a manufacturer of industrial machinery, hand tools and household appliances. The founding family still owns an $8 \%$ stake in the company. Another family business that has become a global company is Banco Santander. Emilio Botin inherited a smaller, regional Spanish bank from his father in 1986. The bank, founded in 1857, was owned by two previous generations of the Botin family. It is currently the largest banking group with branches in Chile, Mexico, the United Kingdom and other European countries. Companies (and brands) such as Samsung, Porsche, Levi Strauss, Mars, Wal-Mart Stores, Michelin, Ford, Bechtel, Cargill, Dow Jones, Forbes, Hewlett-Packard, Hilton, Marriott and European brands such as Auchan, Benetton, Carrefour, Fiat, Heineken, IKEA, Lego and Leroy Merlin are family businesses. In Poland, multigenerational continuity and a strong market position have been achieved by A.J. Blikle and Z. Grycan, among others. Some newer Polish family businesses include Fakro, Solaris Bus, ComArch, Koral, Dr Irena Eris, Mokate, Piotr and Paweł, Roleski and Ziaja.

The specificity of family businesses, which is worth emphasizing, is that the owner's family shapes the enterprise in a way that family members cannot do in non-family-owned businesses (Lansberg, 1983). The role of 
the owner and his or her family in the enterprise management process creates unique features, which can, on the one hand, constitute a competitive advantage for them, but on the other hand may prove to be detrimental to their development. The paradox of family businesses is that their features at different stages of development are the strength and source of their success or weakness and failure. In times of uncertainty, core (basic) family values can ensure the continuity of decision-making. On the other hand, sustainable, stable values can inhibit and limit entrepreneurial behaviour and strategic change (Jeżak, Popczyk, WinnickaPopczyk, 2004; Martyniuk, 2013; Fletcher, Melin, Gimeno, 2012; Gibson, Ivancevich, Donnelly, Konopaske, 2008). Therefore, the definition of a family business must cover not only objective criteria, such as the type of ownership, size or way of management, but must also take into account the subjective factors characteristic of this type of business, such as values and attitudes represented by the owner and his or her family, financial responsibility for the company, the involvement of the family in running a business, the strategic orientation of the long-term operation of the company, and concern for planning succession. A feature of these companies (and, at the same time, a certain weakness) is the asymmetry of the flow of information. Entrepreneurs who founded a family business are usually managers and members of the founding family (as illustrated in section 4 at the centre of the model shown in Figure 2.1, common to all three circles - meaning family, company and ownership). However, some individuals may be members of only one group and are placed in one of the external segments of the model. This generates the possibility of information asymmetry and agency problems (Randøy, Goel, 2003). For example, if company decisions are discussed by a family outside the company, during family dinners at home, owners and/or managers who are not family members will be excluded from the information and decision-making process.

Information asymmetry has also been confirmed in studies by Howorth and Ali (2001), which provide evidence of the exclusion of people illustrated in sections 1,2 , and 3 , as well as 5, 6, and 7, from the information process and decision making in various family businesses. In cases where people were members of two groups - sections 5, 6 and 7 (e.g. an owner and family member), information asymmetry continued. Blikle (2012) also points out that each of the fields at the intersection of the areas can be both a level of cooperation and a fighting front, representing different interest groups. At the same time, every direction of communication between different interest groups means scope for diversity, and any diversity is a potential source of synergy.

Q. Fleming pays attention to another important aspect of the family business, namely its life cycle. Both the family business and the family of owners go through different stages of development - different phases of life are conditioned by the biological life cycle of a person, such as the 


\section{ECONOMY AND SOCIAL ENVIRONMENT}

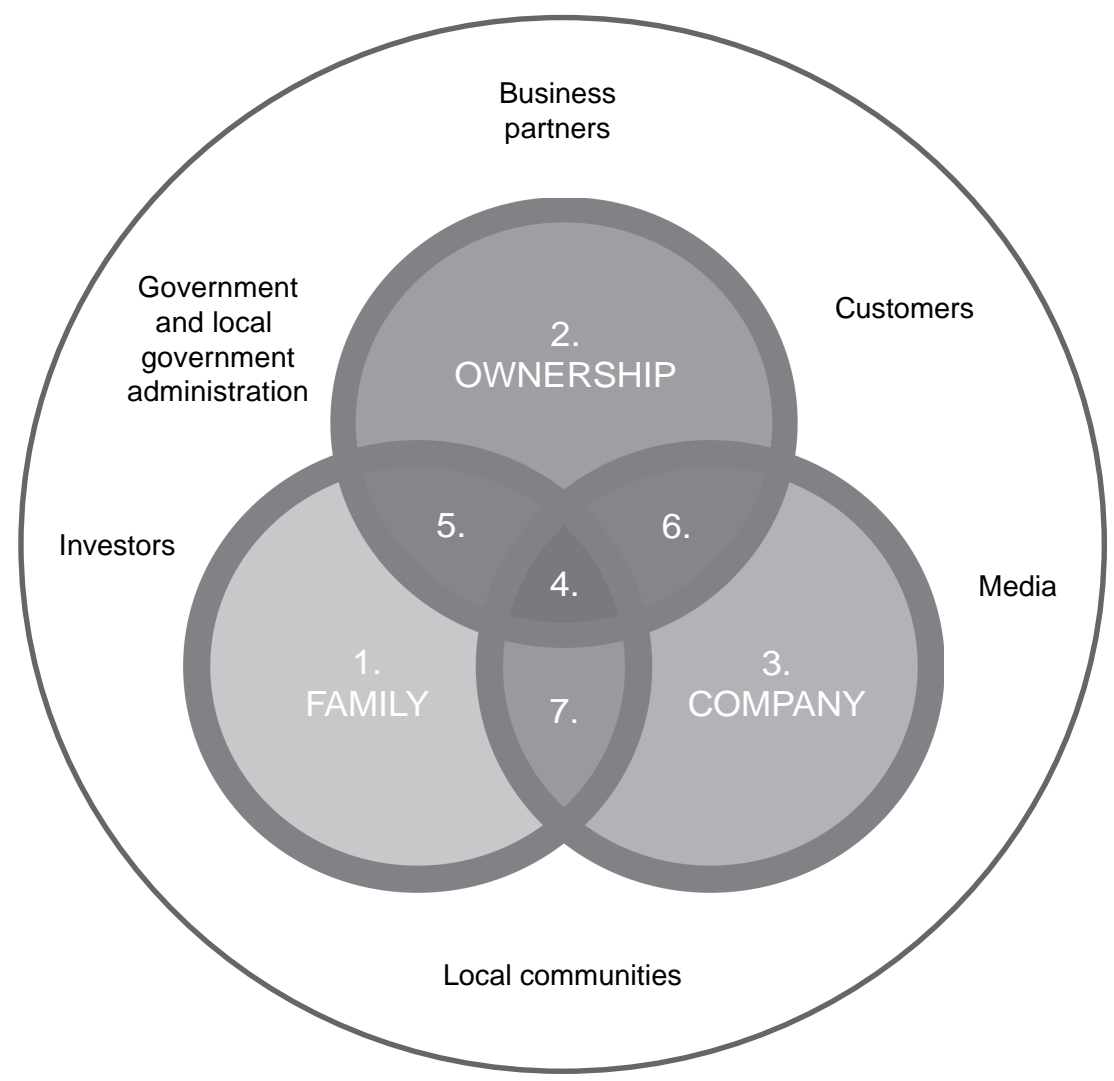

\section{GLOBALISATION}

Figure 2.1 Family business system model

Source: own study based on: Gersick, Davis, McCollom Hampton, and Lansberg (1997, p. 6).

ageing of its founder-owners and their children entering adulthood, combining these processes with a family business. There are two main stages of family development: education and inheritance (Fleming, 2006). It is particularly important to mitigate the transition from one phase to another. Legal, organizational and sociocultural concepts, for example, are developed to implement such challenges posed in the functioning of the family that owns the company. 
Family businesses are characterized by long-term orientation (Miller, Le Breton-Miller, 2006), family identification with the company (Deephouse, Jaskiewicz, 2013) and strong social ties to customers, employees and communities (Arregle, Hitt, Sirmon, Very, 2007). These features, which are worth emphasizing in terms of the research, are particularly motivated to create a unique image and build a good reputation. According to the theory of corporate identity, the family is part of corporate identity (Dyer, Whetten, 2006), which forms the basis of corporate image and reputation. In the case of some family businesses, family ownership is obvious and visible to the public, especially when the family name is part of the company's name. Other companies hide their family ownership in communication with external stakeholders (Zellweger, Kellermanns, Eddleston, Memili, 2012; Carrigan, Buckley, 2008). Family businesses are described as a brand in itself with its typical features. They are customer-friendly, trustworthy and socially responsible on the one hand, while on the other, they are linked to stagnation and lower competitiveness (Binz, Smit, 2013; Cooper, Upton, Seaman, 2005; Krappe, Goutas, Von Schlippe, 2011). An important goal of family businesses is customer orientation. Family members identify more closely with a family business than non-family members who are related to the family. Increased identification motivates family members to gain a positive reputation for the company to feel good about who they are and what they do (Haslam, Ellemers, 2005). Research shows that when the family name is part of the company's name, the corporate reputation is stronger because family members are particularly motivated to make it as good as possible.

As regards reputation-building, the brand of the family business should be taken into account. Many Polish family businesses, including those belonging to the sector of micro, small and medium-sized enterprises as well as large enterprises, are already well-known brands, which can compete with well-known Western brands. They operate according to proven marketing rules, offer quality products and services and competitive prices, have up-to-date knowledge of their consumers, conduct analyses and research, and operate according to long-term strategic development plans and standards in the development of a fullyfledged brand. Branding in the case of a family business entails a "good name", which creates greater difficulties than in the case of other economic entities. This is an emotionally complex situation because the reputation, and hence all associations with the company and the value of its offer, automatically affect the image of the family itself. This in turn influences the way the family is perceived by the environment, which is particularly important for companies operating in local communities, and this includes a large proportion of family businesses. Values are a specific basis for building a family business brand. In terms of brand building, values which accompany its creation should be accepted by a 
brand's target audience - customers and other stakeholders - so that they can identify with it. Having a fully-fledged brand makes the family business more recognizable among other companies with a similar profile. It also gains a competitive advantage on the market and builds a better position, as consumers are ready to accept a higher price for the brand, and "license" to stretch the brand to categories other than the one in which the company has operated up until that point in time is easier. Also, the easier and more favourable sale of the company is possible, if necessary. Moreover, the company has greater resilience in the face of economic crises and economic fluctuations. A strong brand is also a pathway to an easier succession (Nalazek, 2012).

Many authors emphasize the importance of value in family business management. A family business understood as a company - family individual system combines three areas of values. Values, feelings and intellectual processes that define the inner world of the family, and the processes taking place within the organization, are intertwined and interdependent. If their values are convergent and members of the subsystems act under similar rules in pursuit of objectives, synergies are created. The values of the owners and successors of the family business have an impact on the way in which it is managed, which should ensure its continuity and long-term operation. Family values in a company are an element which integrates structures, processes and strategies to achieve maximum value, and they influence the choice of management. Family history creates company history - a coherent system of company value is one of the sources of success of family businesses (Martini, Suardana, Dwijendra, 2017; Parada, Nordqvist, Gimeno, 2010; Szczepańska-Woszczyna, 2018).

Shared values in a family business promote a high degree of corporate loyalty, reduce stress and tension, facilitate a common understanding of the company's main objectives and the purpose of the work, develop confidence in the need for personal efficiency and satisfaction with participation in the organization, develop teamwork and stimulate ethical behaviour.

Over the last few years, in the field of research related to the family business, there has been a search for answers to the question of whether and how family businesses are different from other companies, both in terms of organization and development opportunities. A significant contribution has been made to the identification of the systemic nature of family business behaviour (Davis, Stern, 1980; Whiteside, Brown, 1991), the description of the dual nature of family and business as a source of benefits and disadvantages (Kets de Vries, 1993; Gupta, Levenburg, Moore, Motwani, Schwarz, 2008; Tagiuri, Davis, 1996), and the identification of characteristic activities and opportunities for the development of family businesses. The authors pay attention to family businesses with a unique working environment that supports the family and inspires 
employees, and thus gains their loyalty and trust (Ward, 1988). Research shows that they are characterized by a more flexible approach to the work of employees, lower recruitment costs, lower human resources costs and greater employee productivity (Levering, Moskowitz, 1993; Tagiuri, Davis, 1996), as well as lower transaction costs, less formalization of decision-making and organizational structures, and lower monitoring and control costs. Decision-making is centralized among a small group of family members, which increases company flexibility (Aronoff, Ward, 1995; Daily, Dollinger, 1992). The positive perception of family ownership by customers and business relationships, based on intra- and inter-organizational relations, generate a positive assessment by stakeholders. The reputation of the family makes relationships with suppliers, customers, and other external stakeholders stronger and more valuable (Timothy, Habbershon, Williams, 1992).

At the same time, the weaknesses and limitations of family businesses include:

- the possibility of experiencing limited management and capital resources together with the development of the company;

- activities based on the work of the local community and a small share in the global market;

- the possibility of maintaining poor decisions as a result of the persistence of the family, as well as the limited tendency to take risky decisions;

- the potential mismatch of goals between family members involved in the company's activity and those who are not;

- rigid attachment to best practices, products, location, access channels, technologies, management methods, etc.;

- potential discrimination against employees who are not family members;

- intensified efforts to convince the family and other employees of the vision of the company, which may affect the quality of the operational tasks performed (Dźwigoł-Barosz, 2017);

- weaknesses in the management system, an inability to develop the company's mission, strategy and vision, poor knowledge of marketing activities, conflicts in the value system and a poor ability to control and assess financial status (Stawicka, 2011).

The diversity of family businesses and their behaviour make them an important area of research, which is inherently multidisciplinary, involving sociology, economics, management sciences, culture and history. Understanding a family business requires a multifaceted analysis of complex family and business interactions, core family values and the way they shape the corporate culture, behaviour and decision-making. Family businesses, perceived as mitigating agency problems, responding to risk and uncertainty, prefer to ensure continuity rather than aggressive or 
risky investments. The founders of family businesses are classified as entrepreneurs in any perspective that defines entrepreneurship as synonymous with creating new ventures.

\subsection{Values as a Foundation for the Reputation of a Family Business}

In the 21st century, there is a common belief that organizations which seek only profit, forgetting values such as honesty, reliability, diligence or responsibility, will not build a good reputation and thus fail to secure the success that they will enjoy for many years. The managers of large corporations and much smaller organizations, in particular the owners or leaders of family businesses, are increasingly aware of this fact (Zellweger, Kellermanns, Eddleston, Memili, 2012; Dowling, 2002; Adamik, 2008; Krappe, Goutas, Von Schlippe, 2011). From the outset, the family business model has been conducive to the functioning of the organization on the basis of value. Thus, such entities can be considered precursors of economic activity, which, by acting in accordance with generally recognized values, which are also the values of the owner's family, build a good reputation in the business environment. Family businesses have rarely been established with only a quick profit in mind. It is usually an idea of life, often with the next generation in mind. However, in order to succeed, the company needs to be built on solid foundations - values that are the basis of a good reputation, which helps a company to survive in an increasingly competitive market.

J. Klimek believes that family business employees identify more with company values related to its mission. This results from a sense of community and belonging, and the generation identity that its members have. Family members who run a business are better motivated (Klimek, 2014). Ethical principles and values are a part and characteristic of family businesses, distinguish them and determine their competitive advantage. According to O. Martyniuk and K. Stańczak-Strumiłło, it is values and corporate culture that distinguish family businesses from nonfamily businesses, while they do not differ in terms of structural features such as size, number of employees, revenues, investments and development plans (Martyniuk, Stańczak-Strumiłło, 2012). Values that the founder represents and contributes to the company are crucial to the functioning and coherence of activities in a family business. He or she determines what the most important value contributed to a business is and integrates further actions. Owners significantly influence the company, following their personal goals and preferences in such a way that they are reflected in the company's goals (Szczepańska-Woszczyna, Kurowska-Pysz, 2016; Tàpies, Fernández Moya, 2012). Owners/founders often declare that there is no company without value. Values in family businesses are closely related to different areas of the company's 
operation; they are a "background" for organizational culture, they determine strategic planning, goal setting and the model of business management, determine the way of making decisions, implementing strategies, strategic alliances, inspire the development and the achievement of best results and they are part of the recruitment and retention of employees (Aronoff, Ward, 2016; Marjański, 2012; Miller, Le BretonMiller, Scholnick, 2008; Blikle, 2015). It is emphasized that values in family businesses are also important in terms of overcoming current crises, as in times of uncertainty they can ensure continuity of decisionmaking.

A family business is a social space in which the following are combined:

- family values (group values) - maintaining its stability and security;

- business values (group and individual values) - company development, maintaining (and/or increasing) profit;

- personal values (individual values) - the possibility of pursuing individual values and free choice of a life path (Więcek-Janka, 2013).

In the context of the above discussion, three levels of value can be distinguished: business, cultural and dignity values. Business values are, above all, ensuring the company's stable functioning in the long term, creating jobs for the children of company founders, and profit in the long term (owners do not want fast profits at all costs and not at the cost of the company's existence) (Marjański, 2012; Arregle, Hitt, Sirmon, Very, 2007). Continuity and the choice of successors are key determinants of the actions of family business owners; therefore, they plan for many years ahead and are more likely to reinvest. Their motivation to do so results from the need to support families dependent on the company's prosperity, as well as to maintain, consolidate or multiply wealth for future generations (Jeżak, Popczyk, Winnicka-Popczyk, 2004). Cultural values in family businesses are an attachment to their cultural image and a reluctance to suddenly change brand image, and a lack of acceptance of brand depreciation. Family businesses are characterized by an organizational culture which has high levels of entrepreneurship and solidarity in action, is motivating and family-oriented, and - owing to its authenticity - can naturally become a link forming corporate identity and an important element of competition. Other values in family businesses also include good quality, trust, cooperation, honesty, persistent work, integration and stakeholder satisfaction (Lewandowska, 2013; Stawicka, 2010). Values pertaining to dignity combine the honour of the company with the honour of the family. They assume the building of a good image of the family in the environment. (Safin, 2007). They also mean a lack of consent to unfair actions towards the customer, employee and contractor (Marjański, 2012). In family businesses, activities are often determined by personal human values: diligence, simplicity, loyalty, joy, nobleness 
and courage. It is also important to emphasize the need to combine several roles, a divided identity at the same time. There are different stories of people's lives, emotional commitment, family specificity, worldviews and culture (Stawicka, 2010). J. Tàpies and M. Fernández mention three different groups of values, depending on their impact on the longevity of the company: 1) values that build coherence: respect, loyalty, honesty and reputation, 2) values that affect the company's sustainability: entrepreneurship, excellence, hard work, prudence, quality and profitability, 3) values that support the transfer of core values: social responsibility and management transparency (Tàpies, Fernández Moya, 2012). Research by K. Szczepańska-Woszczyna indicates that family businesses take into account both business and family values in building their management models, such as experience, responsibility, a good atmosphere, reliability, good relationships between family members, stabilization, heritage and sustainability, profit, common goals of the company and individual family members of the owners and the entire family, trust, family reputation, family honour, honesty towards stakeholders, education, the welfare of non-family employees and intuition. These values are permanent in the process of succession (Szczepańska-Woszczyna, 2018).

The value system respected by family business members contributes, among other things, to reduce the distance between owners and subordinates and other stakeholders. Moreover, employees who accept a functioning value system are often more loyal and conscientious, and the involvement of family members also contributes to the degree of their openness and friendly attitude towards employees and customers (Smyczek, Gola, 2011).

Family relationships among company founders are very often a source of ethical behaviour, an expression of sensitivity to the needs of another person, teamwork skills or a sense of community and loyalty. In other words, these relationships translate into family business values professed and respected (Abratt, Kleyn, 2012; Carrigan, Buckley, 2008):

- the good quality of work and products offered;

- mutual trust;

- focus on cooperation;

- honesty;

- hard, persistent work;

- integration;

- stakeholder satisfaction.

Jeżak, Popczyk and Winnicka-Popczyk (2004) point out that the system of family business values, which translates into good corporate reputation, consists of both the principles of a moral obligation which apply to the family and the running of the company, in particular: 
1. the quest to maintain the family nature of the company, succession for the next generation;

2. loyalty, unity, commitment, diligence and employee attachment to the organization;

3. nurturing and cultivating family traditions;

4. consistency, faith and persistence in pursuit of a given goal;

5. faithfulness to the selected sector of action;

6. the identification of the life path of family business members with the economic success of the project being developed;

7. the development of a company of a more evolutionary rather than revolutionary nature;

8. the consolidation of the family around the company.

In the process of building a good reputation, it is therefore very important that the family business does not function solely on the basis of the assumption that it is only a place of work where it is most important to care for the property and the financial needs of the owners. The ability of the owner, or the leader/CEO (Managing Director), to convey the enthusiasm of the adopted plans, projects, as well as the ability to combine family values with professional values - in particular with the personal values of employees - will be crucial (Brown, Dacin, Pratt, Whetten, 2006). In this context, it is very important to distinguish common values, i.e. a set of ideas and beliefs about what is good and desirable and what is bad and harmful to the behaviour of organization members (Craig, Dibrell, Davis, 2008). Family businesses that want to build a good reputation should therefore be not only a place where positions may be filled with family members or relatives, but also organizations which sincerely adhere to the values previously identified, which the family that owns the business and its CEO and employees profess. Compliance with this principle will have a positive impact on the reputation of the family and the company as a whole. In addition, working in a family business, where values are strongly articulated, but above all consistently respected, will bring employees a sense of great security and mental comfort.

An important feature of family businesses, which focuses on values and aims to develop a good reputation, is personalism and family attitude towards each employee (Lee, Marshall, 2013). A team of employees in such a company knows each other well, not only in a professional sense but also privately, which significantly affects a warmer and less pro-transaction approach in the workplace. However, it should be noted that working in a creative atmosphere in a team of people who we enjoy being with brings both joy and stress caused by the possibility of failure, which in a family business in which values are strongly embedded can, however, become a driving force for even more hard work. Wellmanaged employees of this type of company are also usually more 
flexible than in other organizations. In general, they are more aware and understanding of the changing market situation and therefore the need to adapt to the situation (e.g. suspension of bonuses during a recession or working overtime), which significantly translates into a stable situation of the company and thus its reputation (Dowling, 2006). K. Safin points out that the goal of the family is to pursue happiness, while the goal of the company is to create goods and services. A family business, based on values and good reputation, is, therefore, an entity in which both moral and ethical objectives are pursued, such as the survival of the organization, gaining economic independence, building a good reputation for the family and the company as a whole, and economic objectives such as increased profit, increased market share or achieving sales targets (Safin, 2007).

In light of the above discussion, the conclusion that building a reputation in family businesses based on a separate set of values professed by all organization members is a crucial factor in the company's success is justified. This is also supported by the fact that this model is transferred and implemented into the area of operation of large economic entities (non-family corporations) and, importantly, it is increasingly becoming a standard that shapes corporate culture based on values.

\subsection{Relational Capital and Image of the Owner and Family as a Generator of Reputation-building Values}

The importance of reputation is increasingly being raised in family businesses, as well as the benefits it brings in the business management process. The carefully constructed reputation of a family business, protected and maintained, is certainly an important yet sensitive element of the organizational strategy which, on the one hand, enables the company to achieve a competitive advantage in the market, and on the other hand reduces the uncertainty of stakeholders who are key to organizational success. Family business stakeholders are often divided into two groups: the primary one, which includes family, employees, shareholders, customers, competition, lenders, suppliers, wholesalers and retailers, and the secondary one which encompasses local communities, media, social organizations, government and local government institutions, economic organizations and the public (Bonikowska, Grewiński, 2011). Obviously, such a division is a model, and each family business should individually identify its stakeholder map. Unfortunately, very often, while building a relationship between family businesses and primary stakeholders is quite obvious to the owner/CEO, it is not obvious that relationships with secondary stakeholders should be maintained, which is a significant mistake in terms of building the reputation of a family business (Moog, Mirabella, Schlepphorst, 2011). The experience of many family businesses shows that entities invisible to these 
organizations can influence the activities or decisions of primary stakeholders and should therefore be taken into account in the process of building reputation (Bonikowska, Grewiński, 2011). According to A. Adamus-Matuszyńska, a family business should include four main stakeholder groups in the process of building reputation, namely customers as the direct recipients of company's offers, employees, local communities and investors (Adamus-Matuszyńska, 2012). These stakeholder groups, in the opinion of C. Van Riel, form the capital of family reputation, which is the function of the external relational capital of a company (or social capital), created through a network of positive links with the above-mentioned stakeholder groups and appropriate (effective) communication with them. In addition, C. Van Riel points out that the principal components of family reputation are the following values: credibility, trust, loyalty and solidarity (Van Riel, Fombrun, 2007). In other words, through repeated, deep and long-term interactions with these stakeholder groups, family business owners are able to build capital, the components of which include identity, emotional trust, moral and ethical infrastructure and the need for a strong family reputation. W. Popczyk points out that when a family decides to run their own business, they add to it not only the physical and financial assets (buildings, equipment, vehicles or savings), knowledge, skills and competences or the work of its members, but also (and perhaps above all) intangible assets in the form of family relational capital, which very often determines the survival, development and success of the family business in the first years of its operation (Popczyk, 2014).

This capital refers to the potential of networking with stakeholders. This means that a strong, positive moral and ethical infrastructure characteristic of a large proportion of families, and the internal need to take care of the reputation of the family, becomes a generator of values for stakeholders, which evokes their trust in the family business and, as a result, builds its reputation. According to J. Haidt and C. Joseph, the source of the moral and ethical infrastructure of entrepreneurial families is innate, genetic, moral and human intuitions independent of national culture, time and places (Haidt, Joseph, 2014). They guarantee that, through frequent interactions, people can develop shared standards that they will then respect. Gaines-Ross (2003) adds that universal intuitive moral awareness is essential in the process of shaping moral intelligence, which typically develops in the family environment. In turn, this intelligence, brought by the family to the company, implies a choice of methods by which to reconcile its system of values, aspirations and actions with human principles.

Conditions of building a strong reputation of a company based on relational capital, which should be emphasized here, are both the moral and emotional intelligence of the owners' family, as well as an uncompromising $\mathrm{CEO}$ with a strong personality and sense of morality, who 
is responsible for introducing moral and ethical standards to the organizational culture. It should be remembered, however, that in the case of a CEO from outside the family of owners, there is often a strong temptation for a leader to violate moral standards. This is usually the case in a situation where the CEO, seeking to maintain his or her position, tries to please the owners and does not always act morally. Such immoral actions include reducing employment during times of crisis, inadequate pay for employees, or generating savings at the expense of lowering the quality of the goods and services offered. However, a CEO acting in this way has little chance of proper moral dialogue with stakeholders and, as a result, building the relational capital that underlies the reputation of owners and the entire family business.

The reputation of a family business is undoubtedly linked to the image of the country or industry where the organization operates, but above all, it is linked to the image of the CEO of the organization or the owner of the company. In the 21st century, family business managers have become the subject of great interest in the media and often, as the "faces" of their organizations, have a huge influence on the formation of opinions about the business they run. It is usually the CEO of the family business that bears the main burden of building the reputation of the organization in all its dimensions. At the same time, the leader, in some sense, becomes part of this reputation, as a person who embodies company value. It is therefore worth taking a closer look at how the characteristics of a leader can translate into a comprehensive assessment of the family business.

Research into the impact of the CEO's image on the reputation of a family business proves ${ }^{1}$ that the image of the CEO or the owner of the organization is inextricably linked to the reputation of the family business in general. As a result, the vast majority of the capital created for the family business by its good reputation lies with the owner of the organization or the CEO. It should therefore be noted that collective admiration, respect or, finally, charisma (a certain quality of an individual personality, by virtue of which he is set apart from ordinary men treated as endowed with supernatural, superhuman, or at least specifically exceptional powers or qualities, (...) not accessible to the ordinary person (...) and on the basis of them the individual concerned is treated as a leader [...] (Weber, 2002), which the leader enjoys, is a very important form of capital that brings significant benefits to the family business, which increases the chances of an organization achieving market success, for example by attracting stakeholders: able employees (valued specialists), partners, investors or finally customers (Gaines-Ross, 2003). It can therefore be stated that the CEO embodies the organizational brand and its public perception is crucial to the level of trust in the family business and its credibility. ${ }^{2}$ According to Weber's Charismatic Leadership Theory (CLT) (Weber, 2002), charismatic leaders have their primary 
effects on followers (primarily internal stakeholders) through the social influence process of identification (Weber, 2002). The main emphasis in this theory was placed on the relationship between the CEO and his/her followers, which is based on the behaviour of the leader in combination with certain characteristics of his/her followers. This theory also emphasizes the emotional and symbolic attraction of the CEO's behaviour, such as visionary imagination and building one's own image. The findings of A. Fanelli and V. Misangyi, in turn, extended the application of CLT theory beyond the organizational area, combining the interaction of a charismatic leader not only with a group of followers (internal stakeholders - employees of the organization), but also with external stakeholders of the family business (Fanelli, Misangyi, 2006). According to the authors, the charisma of the leader of the organization is a social image created primarily by the media, an image that specifies the family business and provides an explanation of its achievements. In their understanding, the charismatic leader is, therefore, a publicly created persona, who symbolizes control over the achievements of the organization. $\mathrm{He}$ is a person with an archetypal, somewhat simplified image, a result of glorifying and mythologizing leadership. The charisma of the owner or $\mathrm{CEO}$ of the family business, therefore, affects corporate reputation both directly, through organizational narrative, and indirectly, with the participation of intermediary institutions (e.g. the media) - Figure 2.2.

The information presented in the figure shows that both the charismatic image of the CEO and his/her charismatic behaviour have an influence on the process of forming the reputation of a family business (Fanelli, Misangyi, 2006). The charismatic image of the CEO refers to the extent to which the organizational narrative describes the leader and his/her vision of the future. According to Fombrun and Van Riel (2004), this image can directly affect the reputation of the family business, for three reasons:

- the charisma of the CEO, as a kind of archetype, enhances the sense of security among stakeholders, as it reduces uncertainty about the features of the family business;

- the charisma of the CEO and the components thereof increase the visibility and recognition of the family business among its competitors or its contractors, which is one of the fundamental conditions for having a good reputation. Research conducted by the Reputation Institute shows that the more recognizable the company is, the more positively it is assessed by external stakeholders;

- external stakeholders tend to mythologize leadership, and the charismatic image of the CEO, which they learn from the organizational narrative, is in line with this trend.

In turn, the main aim of the leader's charismatic behaviour is to make internal stakeholders aware of values, behaviours, or beliefs desired in 


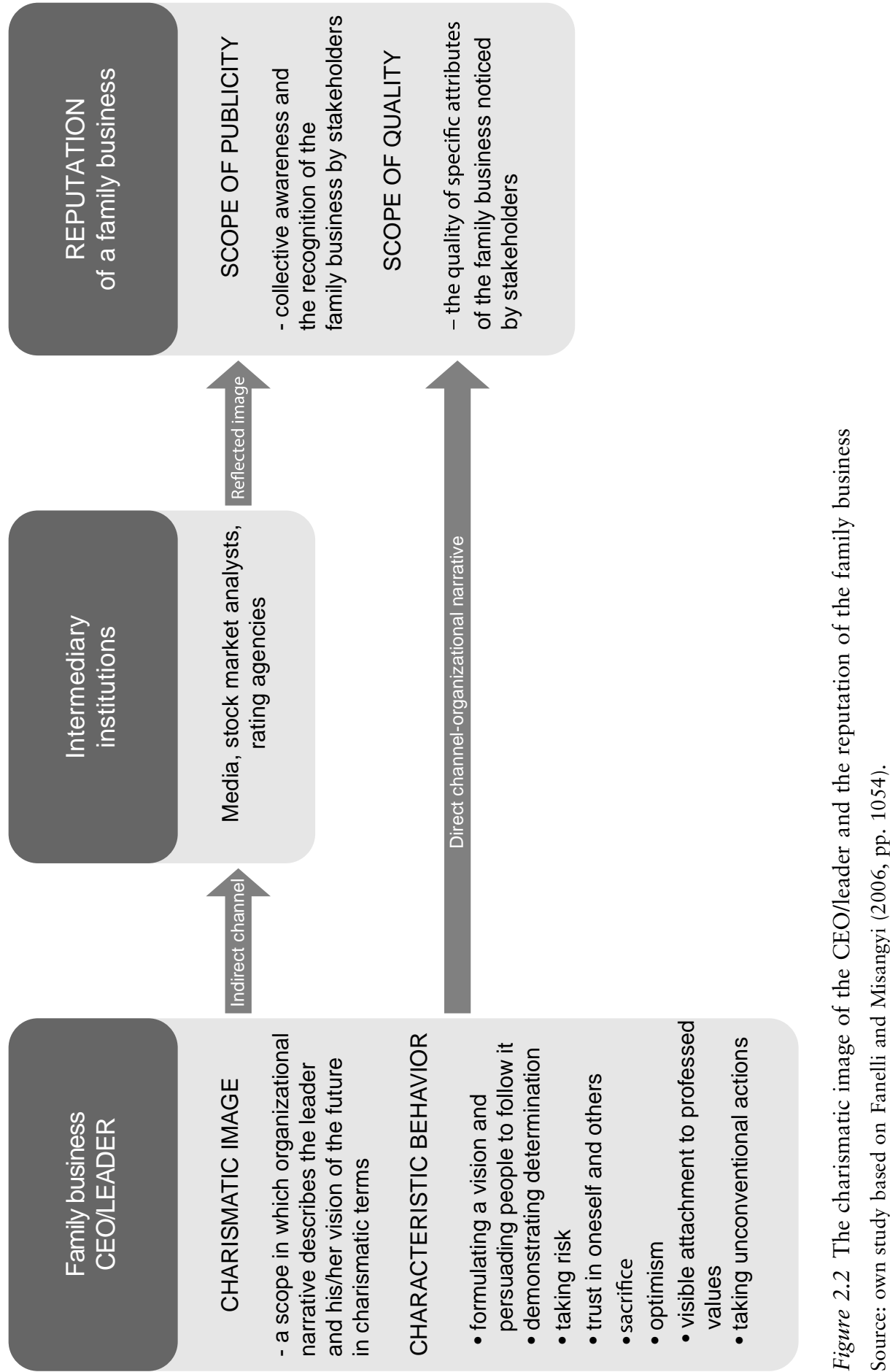


the organization. These behaviours are intended to evoke commitment to integrating the professional and personal identity of employees into the identity of the entire company. These behaviours have a particularly significant impact on family business employees, as they are directly observed and analyzed.

In a family business, the owner-manager is both a creator and a "doer" who implements certain values. Through their behaviour, decision-making and articulated values, managers manifest their personal values (Hemingway, Maclagan, 2004). The scale of business objectives for SMEs is linked with the owner-manager, for whom the link between personal and business success is much closer than in the case of delegating managerial competencies to others, and takes the form of ethical and responsible behaviour regardless of the outcome. In this context, the sense of belonging on the part of the entrepreneur and his/ her sense of being part of the community acts as a "launching pad" from which to create conditions conducive to company development.

They are not so important to external stakeholders, as they are usually available to them to a very limited extent. Therefore, in the case of external stakeholders, the main source of traits attributed to the leader is the organizational narrative. This is mainly defined by the way family business members interact with external stakeholders, meet, prepare documents and tell stories or jokes. According to Van Dijk, this narrative consists of an organizational "resource", i.e. the daily activities (Van Dijk, 2009), such as the vision or philosophy of the organization, marketing communication, financial reports, press releases or CEO letters to shareholders.

The charisma of the CEO can also have an indirect impact on the reputation of a family business. Organizations use a message of different types of intermediary institutions, which, through published articles, reports or rankings, shape a certain reflective image of the family business. This image is often referred to as a distorted image, as it is not created directly by the organization, but by intermediary institutions such as media and rating agencies. The activity of independent intermediaries allows the organization to become more visible, but also more reliable for external stakeholders and for the public as a whole. The charismatic image of the CEO affects images developed and transmitted by intermediary institutions and, as a result, the reputation of the family business (Fanelli, Misangyi, 2006). In other words, the charismatic image of a leader builds a dimension of publicity in the case of the reputation of a family business, i.e. collective awareness and recognition which the organization ensures for itself in the environment. A factor which additionally fosters the good reputation of the family business is the compatibility of the reflected images transmitted by different intermediaries. As regards family businesses, the charismatic image of the leader is also very often taken into account when compiling the 
assessments of the company offered by the media or rating agencies, in the form of different types of rankings and reports. The image of the CEO can significantly affect the company's position in the ranking. A leader with charisma (good image) significantly increases the awareness of the family business in the environment, thereby improving its reputation and enhancing the organization's identification by all stakeholder groups. The CEO, as the most visible player of the company, is, therefore, the face of the company, which provides the supporters of the organization (internal and external stakeholders) with a sense of meaning to all the activities it undertakes.

In terms of the creation and maintenance of the image of the leader and its importance for building reputation, which must be emphasized here, the moment of generational change is significant. A change of leader, the employment of internal managers, the intensification of conflicts between family managers, the expansion of the group of external funders and the use of external specialists in family businesses may all lead to differences arising as a result of comparisons between the first and subsequent generations.

\subsection{Building the Reputation of a Family Business on the Basis of the Concept of CSR}

When considering the concept of Corporate Social Responsibility (CSR) historically, it can be seen that this concept originated in family businesses. The local nature of such entities means that they are assessed more by local communities than other companies, which is particularly noticeable when the place of residence of owners coincides with the location of the family business (Martyniuk, Gierusz, 2016). According to Niehm, this is naturally conducive to socially responsible family businesses (Niehm, Swinney, Miller, 2008). Górnik-Durose and Zaleski (2004) believe that conducting one's own business is characterized by greater involvement in work, including work for others (family members, family business employees, or the local community in which the organization operates). According to C. Cruz, the basic features of family businesses are fundamentally a solid foundation for the implementation of CSR standards by such organizations (Cruz, LazarraKintana, Garcés-Galdeano, Berrone, 2014). Family values, long-term orientation or willingness to bequeath the company to successors - future generations of the family - tend to influence the greater involvement of these organizations in social issues, especially in the local environment (Starnawska, Popowska, 2015).

The analysis of the extant literature gives rise to the assertion that corporate social responsibility derives from business ethics and recognizes that organizations, in addition to their economic and legal responsibility, commit themselves to actions which contribute to the 
protection and upgrading of social standards, which is particularly important for family businesses (Kuszaj-Milewska, 2012). Therefore, it is not surprising that more attention is increasingly devoted to these issues in the debate on family business management. This concept can be particularly helpful in defining the direction which a family business should follow. It opens up such entities to a new way of thinking, positively affects the reputation of a family business, or pays attention to previously unseen opportunities and markets.

Corporate social responsibility is a multidimensional phenomenon, and its final shape is influenced by numerous different factors. The European Commission defines CSR as a business management style of integrating social, environmental, ethical and human rights issues into business activities and strategies, in cooperation with stakeholders (European Competitiveness Report, 2008).2008 [2009]). CSR activities should, therefore, not only be part of the promotion activities of family businesses, but also result from the high level of public awareness of the $\mathrm{CEO}$ and his/her deeper need to engage in socially important problems. In other words, family businesses, being in line with the concept of CSR, should show voluntary care for all stakeholders, and take care to act morally and impeccably, which goes significantly beyond the mere observance of the law (Bazzichi, 2003). In the opinion of the author, family businesses which want to build their reputation based on the concept of corporate social responsibility should, first of all, focus on responsibility referring to the classical 5P marketing concept, namely:

- $\quad$ product and product process responsibility (product);

- responsibilities in the supply and distribution process (place);

- responsible pricing policy (price);

- responsible marketing communication (promotion);

- responsibilities for employees (people).

According to Adamczyk (2009), this responsibility can be taken up in different forms and may concern, for example:

- manufacturing and supplying socially desirable goods and services in an efficient and simultaneously ethical manner;

- promoting the family business through sponsorship of culture, science or sport;

- social initiatives for the benefit of the local community;

- philanthropic activities, e.g. regular charity events.

The idea of the social responsibility of family businesses is therefore based on the belief that this organization should take the interests of individuals, groups or entities which the company influences into account, but also those that may affect its functioning, which is in line with the reputation- 


\section{Reputation of Family Businesses}

building process in such entities. The Stakeholder Theory is treated here as the foundation of the concept of CSR, as it underlines the essence of doing business by building transparent, long-term and lasting relationships with all stakeholders: with the family, employees, customers, suppliers and cooperators, with the local community and with representatives of any organization that may influence the family business (Paliwoda-Matiolańska, 2009). When implementing the concept of CSR in family businesses, it should be remembered, however, that these organizations are a unique type of economic entity, whose specificity is determined by two partially overlapping subsystems - family and economic subsystems (i.e. the family and the company). According to Frishkoff (2005), the lack of a clear distinction between family and business means that family values influence the organization management model, and family history creates the history of the company. In the context of the possibility of implementing the idea of corporate social responsibility, this situation can also be a source of both advantages and weaknesses in family businesses. According to R.G. Long and K.M. Mathews, one of the advantages is the concern to ensure the continuity of the company. This manifests itself, inter alia, in the pursuit of family ownership and/or power transfer, resulting in the long-term orientation of family businesses, and thus their more ethical behaviour towards stakeholders, and consequently a good reputation (Long, Mathews, 2011).

In the opinion of P. Berrone, C.C. Cruz and L.R. Gomez-Mejia, the reputation of a family business is often identified with the reputation of the family. Therefore, family business owners are more willing to be involved in pro-social activities, even if this commitment does not bring additional economic benefits (Berrone, Cruz, Gomez-Mejia, 2012).

J.J. Chrisman, J. Kotlar and A. De Massis also point out that the coherence of the owner's family subsystem (which may be manifested by altruism and the result of greater care for employees, contractors or environment) and the company may also result from a specific hierarchy of objectives, which are not always supported by economic logic (Chrisman, Chua, Pearson, Barnett, 2012; Kotlar, De Massis, 2013). Concurrently, other researchers pay attention to the fact that overlapping family and economic subsystems may also constitute an organizational weakness in the context of reputation building based on the idea of corporate social responsibility. R.S. Reid, J.S. Adams et al. draw attention to the relatively common phenomenon of nepotism in family businesses (Reid, Adams, 2001; Astrachan, Kolenko, 1994; Burkart, Panunzi, Shleifer, 2003), which, according to J.H. Chua, may mean an unfair remuneration system and the division of responsibilities between organization members or the hiring and promotion of incompetent persons with family connections (Chua, Chrisman, Bergiel, 2009), among others. According to Mazur-Wierzbicka (2014), barriers which hinder reputation building through the implementation of the idea of 
corporate social responsibility in family businesses also include the lack of knowledge of owners and skills in using CSR tools, which involves, inter alia, the tendency to focus on the present and, as a result, a reluctance to think strategically. In addition, Popławski points out that, due to the simplicity of thinking and acting, family businesses often tend to treat the company as a system without dependencies and feedback (Popławski, 2003). Banasiak, on the other hand, points to the fact that family business owners frequently confuse corporate social responsibility with cost-generating philanthropic activity (Banasiak, 2014).

M. Kuttner and B. Feldbaure-Durstmuller observe the growing importance of CSR activities in family businesses (research on family businesses in Austria). CSR activities are strongly influenced by members of the founding family. As research demonstrates, the main motives for involvement in CSR are building image and reputation, strengthening one's position among local communities, and relationships with employees. CSR activities are also a tool for achieving specific objectives CSR activities concerning employees and the close business environment, and environmental CSR activities are required as a criterion for certification. Actions for the benefit of stakeholders derive from both external and internal pressures (Greszta, 2001). External pressure comes from the actions of the competition, which seeks new ways to compete on the market, from customers who are starting to prefer responsible companies in their purchasing decisions, as well as from authorities and opinion-making organizations. At the same time, internal stakeholders employees who want to work in favourable conditions, as well as owners and investors who recognize the growing importance of respecting certain ethical principles in business - all have an impact.

A review of CSR literature shows that the close involvement of family business owners in activities for the benefit of local communities stems from their respect for traditions and family values cultivated over generations, seeking a good name in the environment and setting a direct example for their children (Jeżak, Popczyk, Winnicka-Popczyk, 2004).

\subsection{The Issue of Succession and the Reputation of a Family Business}

According to Kałużna, a family business based on common values is one of the best forms of education for children. Working in such an organization is instructive on the one hand, and on the other, it gives young people the opportunity to pursue their professional ambitions.

The professional knowledge gained during their studies allows them to have a chance to develop their business and thus increase their profits. $\mathrm{H}$. Kałużna emphasizes that young people are more open to risk, new ideas and innovations, which, combined with experience, commitment and openness to parental change, often produce surprisingly good results 
(Kałużna, 2009). Succession in family businesses is therefore important not only because of reputation or the continued functioning of the organization, but above all, it enables the development of future generations. The transfer of power to the next generation became such an important and topical issue in Poland during the 2010s that this issue is increasingly reflected in many literature studies and empirical research (Budziak, 2012; Stępniewska, 2013; Olkiewicz, 2013; Marjański, 2012). The issue of succession is also vitally important in terms of building the reputation of a family business (Murray, 2016). According to M.K. Fiegener, M.B. Brown, et al., in these companies, reputation is strongly associated with the image of the owner/CEO, who is very often the face of the entire organization. It is therefore extremely important that succession in the family business proceeds without damage to the reputation that the previous owner managed to build (Fiegener, Brown, Prince, File, 1996). To avoid such a situation, succession should take place slowly in two processes, i.e. the transfer of ownership and transfer of control. In M. Stradomski's view, both processes should be conducted in parallel, which is relatively rare in practice. First of all, control rights are transferred, followed by the transfer of ownership (Stradomski, 2010). M.H. Moris and P. Sharma point out that, for the succession to be completed without damage to the reputation of the company and the family, it should be planned well ahead of time (Morris, Williams, Allen, Avila, 1997; Sharma, Chrisman, Chua, 2003). However, research conducted by P.O. Bjuggren and L.G. Sund shows that in practice successions are not planned on time, especially in the first generation of entrepreneurs. Such a situation may give rise to unnecessary tensions in the owner's family and have an adverse impact on its reputation as a result (Bjuggren, Sund, 2001; Sharma, Chrisman, Chua, 2003). Nevertheless, M.C. Sonfield and R.L. Lussier add that succession planning is a much more common phenomenon in second- and third-generation family businesses. Handler (1994) also points out that, for the sake of the reputation of the family business and the owner's family itself, it is important that the agreement between the owner and the successor is transparent and precise, so that the whole process of succession does not adversely affect the current functioning of the company.

Part of the succession process is maintenance or change/evolution of values. According to J. Klimek, inasmuch as we are dealing with the evolution of a family business across successive generations, the proven, timeless values remain intact (Lewandowska, Więcek-Janka, HadryśNowak, Wojewoda, Tylczyński, 2016). The successors of companies which participated in the Family company is a brand research share this view: the values of a family business, regardless of which generation, should always remain the same. [...] company DNA is something permanent, sustainable and timeless, only slight modifications can be made when the environment changes $[\ldots]$ the family business represents family 
values that the founder gave rise to and which are passed down from generation to generation. Their weight increases over time. As [...] the company expands, common values become an increasingly important bonding factor. According to A. Lewandowska, the basis for successful succession is the implementation of the model, in which elders should pass knowledge, power and ownership on to the next generation, based on the values they profess (Lewandowska, 2015). The presence of the first three elements does not guarantee success, and values underlie the other three pillars. In research by J. Tàpies and M. Fernández (2012), respondents expressed the belief that values evolve in the process of passing them to subsequent generations.

The attitude to the sustainability of values in the succession process is also illustrated by the results of research ${ }^{3}$ by Deloitte, which shows that successors are ready to preserve the family nature of the activity and family values, ensure the development of a business in a rapidly changing business and economic environment, and maintain the company's independent ownership, although $40 \%$ of respondents do not rule out opening up to external investors. At the same time, the young generation of family business owners intends to introduce changes after taking over: $80 \%$ say that their leadership style will be different from that of the previous generation, $56 \%$ plan to change the strategy of the family business, $56 \%$ intend to change the structure of corporate governance, and $51 \%$ intend to take risks more often than their predecessors, but in a more controlled way (Szczepańska-Woszczyna, 2018).

To sum up, succession is, therefore, crucial for the reputation of a family business and its process should therefore be conducted smoothly and be closely linked to the organization's strategic objectives (Szczepańska-Woszczyna, 2018). It should be borne in mind that this process can have both a positive and negative impact on corporate reputation and its continued functioning (Gersick, Lansberg, Desjardins, Dunn, 1999). Boguszewicz-Kreft and Złotowska (2009) believe that family businesses, with their uniqueness in terms of family values that are passed down from generation to generation and thanks to their consistently built reputation, have a chance for long-term, stable development. There is no doubt, therefore, that the successful succession process determines corporate reputation and has a considerable impact on the dynamics of family business development. At the same time, E. GarciaAlvarez pays attention to the occurring threat. In his opinion, the introduction of potential successors into the organization involves the transfer of values expressed by the current owner to the successor. Such values may deviate significantly from those accepted by the successor (Garcia-Alvarez, Lopez-Sintas, Gonsalvo, 2002). The intergenerational change often leads to a large gap between the "new" and "old" owner/ CEO. This discrepancy concerns not only age (approximately 25-30 years' difference) or experience, but also beliefs (Handler, 1994). M. 
Kets de Vries, D. Miller and A. Kimhi warn that intergenerational change in family businesses, in particular the immaturity of the successor and, consequently, the frequent intergenerational tensions in the family of owners, can significantly increase the likelihood of revolt or submission, resulting in an adverse impact on the reputation of the family and the company (Kets de Vries, 1993).

Family businesses are a group of entities which are important to the economies of many countries. Organizations that bring family entrepreneurs together are increasingly emerging, e.g. the international Family Business Network or the Polish Family Business Initiative. Recognizing the role of family businesses, the European Commission set up an expert group on family businesses in 2007. However, their significant differentiation and the lack of uniform criteria that would make it possible to clearly identify the status of a company led to divergences in the perception of the entire group.

Family businesses are a characteristic group of economic entities that connect the areas of family and business. This category includes both small economic entities and large family-controlled enterprises. Family businesses are usually distinguished by family ownership structure, strategic control over the company by the family, the involvement of family members in management, and the involvement of more than one generation in the operation of the company and the desire to maintain it for the next generation. Family businesses must maintain a balance between achieving business (including development, innovation and hiring talented employees) and family goals (e.g. preserving family values and protecting family property).

The specificity of family businesses allows for the identification of several areas that affect the way the company is perceived by stakeholders and its reputation. These areas include the values of family businesses, cooperation with stakeholders, and family capital as a specific form of social capital, created only in the environment of family relationships, including positive network relationships between family members, family and customers and between family and local communities, corporate social responsibility, the image of the leader (owner) of the family business and succession.

The values of owners and successors of a family business determine the model of business management. The results of research show that knowledge of and respect for company values by owners and building the company's goals based on these values are one of the principles of family business management. Values in family businesses also relate to the principles underlying the functioning of these companies, as well as to the choice of strategic objectives. It is assumed that family businesses are characterized by respect and attachment to traditions, care for employees, responsibility in business and a long-term attitude and high quality of the products offered. 
Stakeholders of the family business, namely customers - direct recipients of the company offers, employees, the local community and investors, create the reputation of the family, which is the function of the external relational capital of the company (or social capital) created through a network of positive links with the above-mentioned stakeholder groups and appropriate (effective) communication with them. Family business owners, through repeated, deep and long-term interactions with these stakeholder groups, are able to build capital, the components of which are identity, emotional trust, moral and ethical infrastructure and the need for a strong family reputation.

The reputation of the family business is also linked to the image of the owner/founder of the company or the CEO (Chief Executive Officer) of the organization. A great deal of media interest in people who manage family businesses, who often have a considerable influence as the "faces" of their organizations on the formation of opinions about the business that they run, can be observed. They often take on the main burden of building corporate reputation in all its dimensions. The leader becomes, in a sense, part of this reputation, as a person who embodies a companyșs values.

Succession is a special moment for the functioning of family businesses, which was made clear during the analysis of the extant literature and by presenting the results of practical research. It is a dynamic process aimed at transferring knowledge, power and ownership to the younger generation while maintaining individual values for a given business and family, which are important for both sides of the process. At a time of generational change, family businesses may find themselves in a difficult situation, which often involves a conflict between respecting traditions and values and the desire to continue cultivating them and the need to adapt and modernize the business in line with changes in its environment. Successors must identify and maintain the values that created the company's specific essence. Company stakeholders often expect that the standards which they have been used to by previous owners are maintained. At the same time, in addition to values embedded in traditions, the ones that allow for innovation and the anticipation of market changes are also important, which is a challenge for successors.

A closer look at the sources of wealth and employment growth has brought researchers' attention to the specific area of micro, small, medium-sized and even large organizations - family businesses. Their fragmented structure and lack of consensus on the criteria of distinction complicate the generalization of operating principles, but at the same time creates a satisfying object for theoretical disputes and research.

The family business is linked to the category of value, which reflects the internal world of the owner's family and business. In particular, values that the owner professes have a decisive influence on business management and reputation. The image of the leader in a family business 
is associated with reputation, or even identified with it, to a greater extent than in other companies. Research results so far confirm the close link between business and personal goals of the family business manager and a strong emphasis on the ethical side of the business. In such companies, the concept of corporate social responsibility was born, spreading throughout the economy over time. The proximity of the local environment naturally sets the direction of the company's ethical activities, subjected to a direct, visible assessment. Social activities have such an impact on the corporate reputation that they can be identified with it.

Problems relevant to each organization, such as decision making, trust, integration, management styles, etc., also occur in family businesses. The question arises whether they differ significantly from "nonfamily" ones in terms of form, character or dimension. The key to finding an answer is to look at the culture of family businesses, especially the ethical principles that are specific to them. There are three levels of values, business, cultural and dignified. These values determine stakeholder relationships, and corporate reputation depends on the shape of these relationships. The logical consequence of the need to build relationships is to incorporate relational capital into reputation management. A specific form of the relationship is succession, which has a considerable impact on the level of reputation. A crucial issue for corporate reputation is the way and extent to which values are passed on to successive generations and how successors relate to them.

\subsection{The Issue of Reputation in Internationalization of a Family Business}

The issue of the internationalization of family businesses is relatively poorly recognized both in Poland and in other countries - all the more so as there is no in-depth research to describe the impact of the reputation of the owner's family on the internationalization of the family business. The analysis of certain scientific reports shows that one of the characteristics of family businesses is operation on the domestic market (Sciascia, Mazzola, Astrachan, Pieper, 2010). Research conducted by Fernandez and Nieto shows that family businesses are reluctant to engage in any foreign activity, and that they are unable to make proper use of their resources in the process of internationalization, especially intangible ones (Fernández, Nieto, 2005). According to Gallo and Sveen (1991) and Ward and Smith (2003), the main factors hindering foreign expansion by family businesses are organizational constraints, as well as the family's fear of losing control of the company. Casillas and Acedo (2005) and Zahra (2018) point to the excessive tendency of owners to avoid risk, while Gallo and Pont (1996) highlight the lack of sufficient financial resources to enter the international market. In addition, some research shows that management capabilities in terms of internationalization are lower among managers of family 
businesses than managers of non-family businesses. However, the author's research conducted in Poland, as well as the high level of activity of family businesses on foreign markets observed in the last two decades, seems to contradict some of these reports. The examples of both Polish companies ${ }^{4}$ and companies in other countries ${ }^{5}$ (organizations where managers are also members of the owners' family) prove that special competencies of family members and the good reputation of the family allowed for the successful introduction of many companies to the international market. Moreover, we can observe fast-moving internationalization not only among large family businesses, such as Jeronimo Martins, GAP or Levis, but also in the sector of small and medium-sized enterprises. The author's findings are confirmed, inter alia, by Thomas and Graves' research, which shows that a factor that stimulates the internationalization of the family business is its reputation, built through the direct involvement of the owner's family, long-term company orientation, and speed of decision-making (Graves, Thomas, 2004; 2006; Thomas, Graves, 2005). Therefore, it has been argued that family businesses that decide to go beyond the national market decide to internationalize their activity, taking the long-term conditions of the organization into account (Pukall, Calabrò, 2013). Taking the globalization of the markets, technological progress or virtualization of consumption into account, this thesis or increased activity on the international market does not seem surprising. Nor is it unusual that the process of the internationalization of family businesses is very closely related to their reputation, which is the result of trust built on the responsibility and credibility of the owners' family. In practice, this means that values which prevail among family members are transferred to the organization and affect relationships with customers, suppliers or foreign partners. A good reputation is therefore an important factor affecting the competitive position of a family business on the international market.

Research conducted by Swinth and Vinton among a group of family businesses shows that the reputation of the family business, and therefore the trust the company evokes, helps managers to enter into agreements, form joint ventures with other companies, or strategic alliances in the international market (Swinth, Vinton, 1993). Research has also shown that family business managers are guided by the reputation and family character of the company in choosing a foreign partner. This is also confirmed by research among a group of Polish family businesses conducted for the purposes of this book. The author believes that the relationship between family businesses could be facilitated by sharing a similar system of values, long-term prospects of action, commitment, loyalty or a particular type of trust that exists only in the family. As a result, establishing a relationship with a foreign entity based on the reputation of a family business may be a way of company internationalization expressed in: 
- market import and export transactions with varying degrees and in different arrangements (including transit trade);

- cooperation links with a foreign partner based on both financial (e.g. joint ventures, consortia) and non-financial capital (e.g. licenses, franchising, leasing, management contracts, sub-supply contracts), as well as networks of companies or international strategic alliances;

- activities aimed at taking the business into its own organizational and proprietary arrangement (e.g. mergers, acquisitions of enterprises, independent business activity by a family company abroad by means of a branch or subsidiaries).

According to the author, the internationalization of family businesses regardless of how deep it is and what it expresses - must always be viewed in connection with reputation, which in turn is derived from the direct involvement of the owners' family in the management process. The involvement of the family in the operation of the company means that the process of internationalization can go faster and more intensively than when this involvement is lacking. An important aspect of the functioning of family businesses is the fact that knowledge is passed down from generation to generation in these organizations and a particular type of trust exists that promotes stable, long-term relationships with both national and foreign business partners (especially if these partners are also family businesses). According to Jennings, Artz, Gillin and Christodouloy, the trust-built reputation of the family business not only strengthens the ties between foreign partners, but also improves the flexibility of the agreement, shortens the processes of cooperation management, and at the same time improves their quality (Jennings, Artz, Gillin, Christodouloy, 2000). It enables the development of beneficial mechanisms for knowledge transfer and creation and ensures that the opportunistic behaviour of partners is limited (Dent, 2002). In support of these findings, Table 2.3 presents the examples of family businesses that have achieved a strong position on the international market thanks to a good corporate reputation built through the direct involvement of the owners' family.

The information presented in Table 2.3 on the activities of selected international family businesses indicates the role of the family and its reputation in the process of company internationalization. All the listed family businesses began the process of internationalization with exports, which was based on the good reputation of the owners' family, in order to open their own trade offices or production plants abroad in the future. Interestingly, in most cases, international cooperation has been concluded with other family businesses that have an equally good reputation. In all seven listed organizations, the family is still present in company structures and its direct involvement in the management process has been crucial in the process of internationalization (whether 


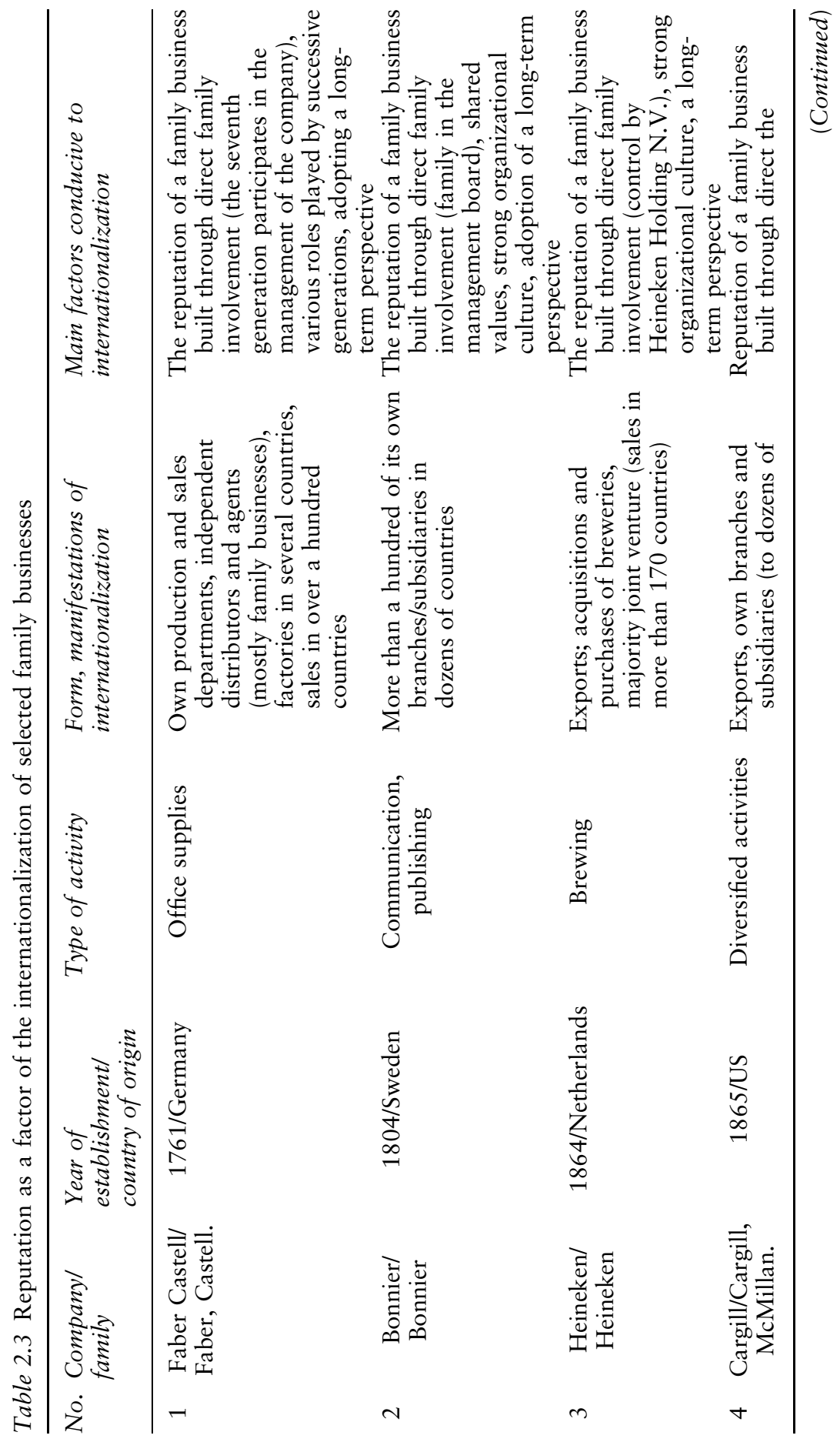




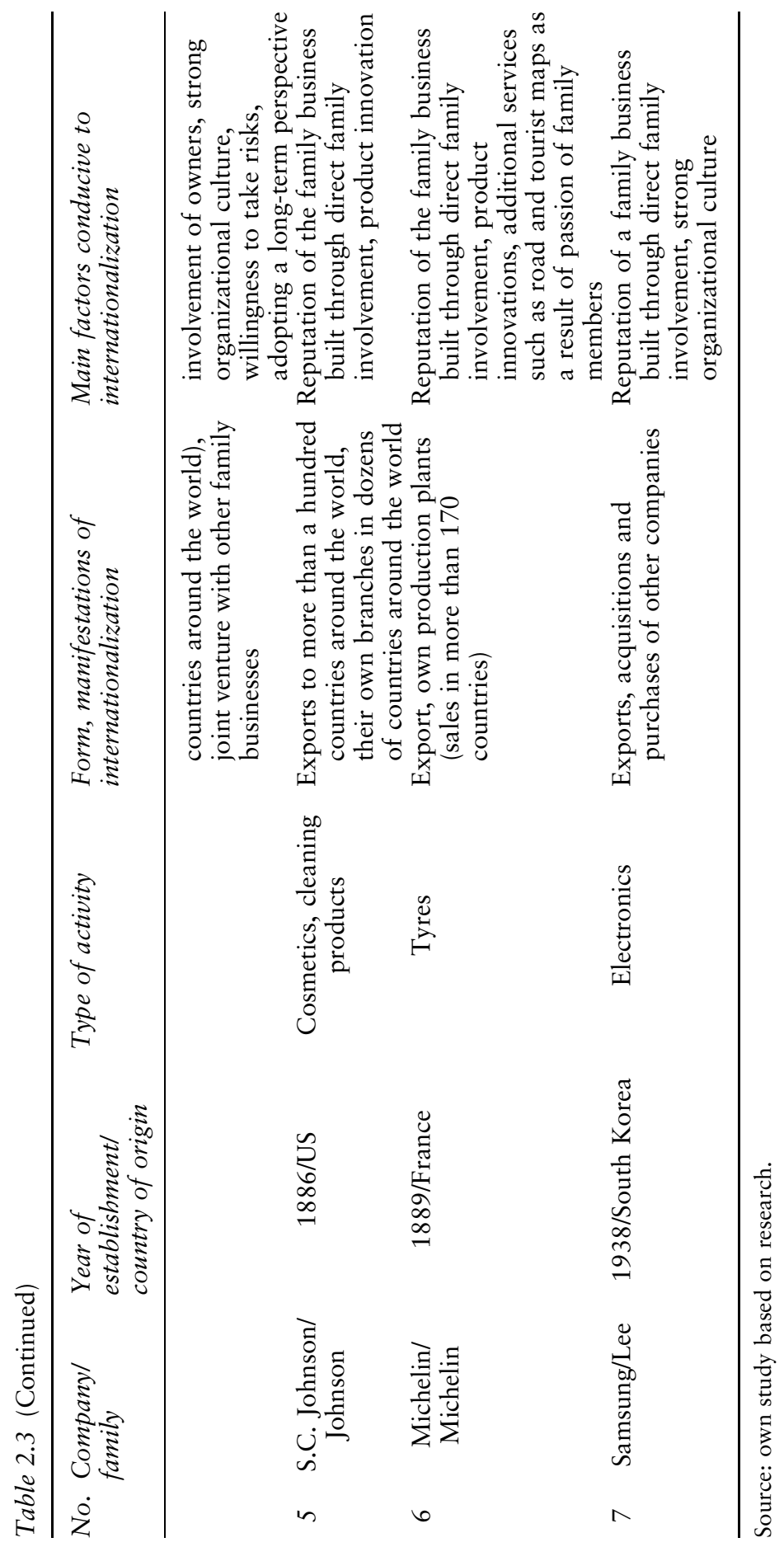


internationalization took place sometime after the establishment of the company - as in the case of Faber-Castell - or since the start of the company, as with Samsung). Thus, shaping the reputation of a family business becomes one of the overriding tasks faced by organizations which operate or plan the internationalization process. It is a building block of non-financial capital allowing companies to enter into relationships, exchange knowledge and do international business more easily.

\section{Notes}

1 For example, research conducted in the United States shows that over $76 \%$ of US business university students associate the image of the CEO with the reputation of the whole company (cf. Feldman, R. (2004). Why Your CEO's Reputation Is Your Company's Message. The Public Relations Strategist, 10(3), p. 24). Other studies show that managers, financial analysts, investors and agency officials are willing to attribute between $48 \%$ and $52 \%$ of overall corporate reputation to an image of the CEO (cf. Gaines-Ross, L. (2003). CEO Capital. A Guide to Building CEO reputation and Company Success. Hoboken: John Wiley \& Sons, p. 19).

2 For example, Walt Disney of the Disney Company; Steve Jobs, founder and long-time CEO of Apple; Bill Packard from HP; and brothers Richard and Maurice McDonald who set up McDonald's restaurants.

3 Research conducted by the Deloitte Centre for Family Businesses in Europe, the Middle East and Africa (EMEA) in 2016; a total of 92 personal interviews were conducted.

4 For example, Mokate is a Polish family business operating on the tea and coffee market.

5 Berluti, for example, is a family shoe business from Italy, and the Finnish company Myllykowski Corporation deals in printing paper.

\section{References}

Abratt, R. and Kleyn, N. (2012). Corporate identity, corporate branding and corporate reputations: Reconciliation and integration. European Journal of Marketing, 46(7/8), pp. 1048-1063.

Adamczyk, J.K. (2009). Spoleczna odpowiedzialność przedsiębiorstw: teoria i praktyka [Corporate social responsibility: Theory and practice]. Warszawa: Polskie Wydawnictwo Ekonomiczne, pp. 143-149.

Adamik, A. (2008). Partnerska współpraca ze środowiskiem biznesowym jako wyznacznik konkurencyjności MŚP [Partner cooperation with the business community as a determinant of the competitiveness of SMEs]. Prace Naukowe Uniwersytetu Ekonomicznego we Wrocławiu, 5, pp. 315-326.

Adamus-Matuszyńska, A. (2012). Reputacja - nieuchwytna wartość firmy [Reputation - an elusive company value]. [online]. Available at: https:// docplayer.pl/218892-Reputacja-nieuchwytna-wartosc-firmy.html [Accessed 10 January 2019].

Aronoff, C.E. and Ward, J.L. (1995). Family-owned businesses: A thing of the past or a model of the future?. Family Business Review, 8(2), pp. 121-130. 
Aronoff, C.E. and Ward, J.L. (2016). Family business values: How to assure a legacy of continuity and success. Berlin: Springer.

Arregle, J.L., Hitt, M.A., Sirmon, D.G. and Very, P. (2007). The development of organizational social capital: Attributes of family firms. Journal of Management Studies, 44(1), pp. 73-95.

Astrachan, J.H. and Kolenko, T.A. (1994). A neglected factor explaining family business success: Human resource practices. Family Business Review, 7(3), pp. 251-262.

Banasiak, A. (2014). Społeczna odpowiedzialność biznesu w zarządzaniu małym przedsiębiorstwem rodzinnym [Corporate social responsibility in small family business management]. Przedsiębiorczość i Zarządzanie, 15(7), pp. 125-134.

Bazzichi, O. (2003). Społeczna odpowiedzialność przedsiębiorstwa [Corporate Social Responsibility]. Społeczeństwo, 55/56(3/4), p. 499.

Beckhard, R. and Dyer, W.J. Jr. (1983). Managing continuity in the familyowned business. Organizational Dynamics, 12(1), pp. 5-12.

Bell, D. (2002). The break-up of family capitalism. In: C.E. Aronoff, J.H. Astrachan and J.L. Ward, eds., Family business sourcebook, 3rd ed. Georgia: Family Entreprise Publishers.

Berrone, P., Cruz, C. and Gomez-Mejia, L.R. (2012). Socioemotional wealth in family firms: A review and agenda for future research. Family Business Review, 25(3), pp. 258-279.

Bertrand, M. and Schoar, A. (2006). The role of family in family firms. Journal of Economic Perspectives, 20(2), pp. 73-96.

Binz, C. and Smit, W. (2013). Sie sind ein familienunternehmen - Na und?!? Eine untersuchung des reputationalen effekts des status familienunternehmen. Betriebswirtschaftliche Forschung Und Praxis, 65(2), pp. 124-136.

Bjuggren, P.O. and Sund, L.G. (2001). Strategic decision making in intergenerational successions of small- and medium-sized family-owned businesses. Family Business Review, 14(1), pp. 11- 23.

Blikle, A. (2012). Specyfika zarządzania w firmach rodzinnych [The specificity of management in family businesses]. In: Firma $w$ rodzinie czy rodzina $w$ firmie. Metodologia wsparcia firm rodzinnych [Business in the family or the family in business. Methodology of support for family businesses], 1st ed. Warszawa: Polska Agencja Rozwoju Przedsiębiorczości, p. 42.

Blikle, A.J. (2015). Firmy rodzinne $w$ obliczu sukcesji [Family businesses in the face of succession]. [online]. Available at: http://www.moznainaczej.com.pl/ firmy-rodzinne-w-obliczu-sukcesji [Accessed 22 February 2019].

Boguszewicz-Kreft, M. and Złotowska, G. (2009). Niematerialne czynniki sukcesu przedsiębiorstw usługowych [Intangible success factors for service providers]. Prace Naukowe Wyższej Szkoły Bankowej w Gdańsku, 4, pp. 117-131.

Bonikowska, M. and Grewiński, M. ed. (2011). Ustugi społeczne odpowiedzialnego biznesu [Social services of responsible business]. Warszawa: Wydawnictwo Wyższej Szkoły Pedagogicznej TWP.

Brown, T.J., Dacin, P.A., Pratt, M.G. and Whetten, D.A. (2006). Identity, intended image, construed image, and reputation: An interdisciplinary framework and suggested terminology. Journal of the Academy of Marketing Science, 34(2), pp. 99-106. 
Budziak, T. (2012). Sukcesja $w$ rodzinie biznesowej: spojrzenie praktyczne [Succession in the business family: a practical view]. Warszawa: Wydawnictwo Poltext.

Burkart, M., Panunzi, F. and Shleifer, A. (2003). Family firms. The Journal of Finance, 58(5), pp. 2167-2201.

Carrigan, M. and Buckley, J. (2008). What's so special about family business? An exploratory study of UK and Irish consumer experiences of family businesses. International Journal of Consumer Studies, 32(6), pp. 656-666.

Casillas, J.C. and Acedo, F.J. (2005). Internationalization of Spanish family SMEs: An analysis of family involvement. International Journal of Globalisation and Small Business, 1(2), pp. 134-151.

Chrisman, J.J., Chua, J.H., Pearson, A.W. and Barnett, T. (2012). Family involvement, family influence, and family-centered non-economic goals in small firms. Entrepreneurship Theory and Practice, 36(2), pp. 267-293.

Chua, J.H., Chrisman, J.J. and Bergiel, E.B. (2009). An agency theoretic analysis of the professionalized family firm. Entrepreneurship Theory and Practice, 33(2), pp. 355-372.

Colli, A. (2003). The History of Family Business, 1850-2000. Cambridge: Cambridge University Press.

Cooper, M.J., Upton, N. and Seaman, S. (2005). Customer relationship management: A comparative analysis of family and nonfamily business practices. Journal of Small Business Management, 43(3), pp. 242-256.

Craig, J.B., Dibrell, C. and Davis, P.S. (2008). Leveraging family-based brand identity to enhance firm competitiveness and performance in family businesses. Journal of Small Business Management, 46(3), pp. 351-371.

Cruz, C., Lazarra-Kintana, M., Garcés-Galdeano, L. and Berrone, P. (2014). Are family firms really more socially responsible? Entrepreneurship Theory and Practice, 38(6), pp. 1296-1316.

Daily, C.M. and Dollinger, M.J. (1992). An empirical examination of ownership structure in family and professionally managed firms. Family Business Review, 5(2), pp. 117-136.

Davis, P. and Stern, D. (1980). Adaptation, survival, and growth of the family business: An integrated systems perspective. Human Relations, 34(4), pp. 207-224.

Deephouse, D.L. and Jaskiewicz, P. (2013). Do family firms have better reputations than non-family firms? An integration of socioemotional wealth and social identity theories. Journal of Management Studies, 50(3), pp. 337-360.

Dent, G. (2002). Lawyers and trust in business alliances. The Business Lawyer, 58(1), pp. 45-82.

Donnelley, R.G. (2002). The Family Business. In: C.E. Aronoff, J.H. Astrachan, J.L. Ward, eds., Family Business Sourcebook, 3rd ed. Georgia: Family Enterprise Publishers.

Dowling, G.R. (2002). Creating corporate reputations. Oxford: Oxford University Press.

Dowling, G.R. (2006). Communicating corporate reputation through stories. California Management Review, 49(1), pp. 82-100. 


\section{8}

Reputation of Family Businesses

Dyer, W.G. and Whetten, D.A. (2006). Family firms and social responsibility: Preliminary evidence from the S\&P 500. Entrepreneurship Theory and Practice, 30(6), pp. 785-802.

Dźwigoł-Barosz, M. (2017). Pojęcie i istota przedsiębiorstwa rodzinnego [The concept and essence of a family business]. Zeszyty Naukowe Wyższej Szkoty Bankowej w Poznaniu, 76(5), pp. 13-23.

European Competitiveness Report 2008. (2009). Luxembourg: Office for Official Publications of the European Communities. [online]. Available at: http://www.eurosfaire.prd.fr/7pc/doc/1251892016_competitivite_ue_2 008.pdf [Accessed 12 May 2020].

Fanelli, A. and Misangyi, V. (2006). Bringing out charisma: CEO Charisma and external stakeholders. Academy of Management Review, 31(4), pp. 1051, 1054, 1056.

Feldman, R. (2004). Why your CEO's reputation is your company's message. The Public Relations Strategist, 10(3), p. 24.

Fernández, Z. and Nieto, M.J. (2005). Internationalization strategy of small and medium-sized family businesses: Some influential factors. Family Business Review, 18(1), pp. 77-89.

Fiegener, M.K., Brown, B.M., Prince, R.A. and File, K.M. (1996). Passing on strategic vision. Favored models of successor preparation by CEOs of family and nonfamily firms. Journal of Small Business Management, 3(34), pp. $15-26$.

Fleming, Q.J. (2006). Tajniki przetrwania firmy rodzinnej [Keep the family baggage out of the family business]. Gliwice: Helion, p. 36.

Fletcher, D., Melin, L. and Gimeno, A. (2012). Culture and values in family business - a review and suggestions for future research. Journal of Family Business Strategy, 3(3), pp. 127-131.

Fombrun, C.J. and Van Riel, C.B.M. (2004). Fame and fortune: How successful companies build winning reputation. New York: Prentice Hall, pp. 86, 104.

Frishkoff, P.A. (2005). Understanding family business: What is a family business?. Austin: Oregon State University, pp. 36-38.

Gaines-Ross, L. (2003). CEO capital. A guide to building CEO reputation and company success. Hoboken: John Wiley \& Sons, p. 19.

Gallo, M.A. and Pont, C.G. (1996). Important factors in family business internationalization. Family Business Review, 9(1), pp. 45-59.

Gallo, M.A. and Sveen, J. (1991), Internationalizing the family business: Facilitating and restraining factors. Family Business Review, 4(2), pp. 181-190.

Garcia-Alvarez, E., Lopez-Sintas, J. and Gonsalvo, P. (2002). Socialization patterns of successors in first- to second-generation family businesses. Family Business Review, 15(3), pp. 189-203.

Gersick, K.E., Davis J.A., McCollom Hampton, M. and Lansberg, I. (1997). Generation to Generation Life Cycles of the Family Business. Boston: Harvard Business School Press, p. 6 
Gersick, K.E., Lansberg, I., Desjardins, M. and Dunn B. (1999). Stages and transitions: Managing changes in the family business. Family Business Review, 13(4), pp. 287-297.

Gibson, J.L., Ivancevich, J.M., Donnelly, J.H. and Konopaske, R. (2008). Organizations: Behavior, Structure and Processes, 13th ed. New York: McGraw Hill.

Górnik-Durose, M. and Zaleski, Z. (2004). Własność i posiadanie [Proprietorship and possession]. In: T. Tyszka, ed., Psychologia ekonomiczna [Economic Psychology], 1st ed. Gdańsk: Gdańskie Wydawnictwo Psychologiczne, p. 129.

Graves, C. and Thomas, J. (2004). Internationalization of the family business: A longitudinal perspective. International Journal of Globalisation and Small Business, 1(1), pp. 7-27.

Graves, C. and Thomas, J. (2006). Internationalisation of Australian family Businesses: A managerial capabilities perspective. Family Business Review, 19(3), pp. 207-224.

Greszta, M. (2001). Na drodze do odpowiedzialnego biznesu [On the way to responsible business]. In: B. Rok, ed., Więcej niz zysk, czyli odpowiedzialny biznes: programy, strategie, standardy [Responsible business - more than just profit: programs, strategies, standards], 1st ed. Warszawa: Forum Odpowiedzialnego Biznesu.

Gupta, V., Levenburg, N., Moore, L., Motwani, J. and Schwarz, T. (2008). Exploring the construct of family business in the emerging markets. International Journal of Business and Emerging Markets, 1(2), pp. 189-208.

Haidt, J. and Joseph, C. (2014). The moral mind: How five sets of innate intuitions guide the development of many culture-specific virtues, and perhaps even modules. In: P. Carruthers, S. Laurence, S. Stich, eds., The innate mind: Foundations and the future. New York: Oxford University Press, p. 20.

Handler, W.C. (1994). Succession in family business: A review of the research. Family Business Review, 7(2), pp. 133-174.

Haslam, S.A. and Ellemers, N. (2005). Social identity in industrial and organizational psychology: Concepts, controversies, and contributions. International Review of Industrial and Organizational Psychology, 20, pp. 39-118.

Hemingway, C.A. and Maclagan, P.W. (2004). Managers' Personal Values as Drivers of Corporate Social Responsibility. Journal of Business Ethics, 50(1), pp. 33-44.

Howorth, C. and Ali, Z.A. (2001). Family business succession in Portugal. Family Business Review, 14(3), pp. 231-244.

Jaffe, D. (1990). Working with ones you love: Conflict resolution and problem solving strategies for successful business. Berkeley, CA.: Conari Press.

Jennings, D.F., Artz, K., Gillin, L.M. and Christodouloy, C. (2000). Determinants of trust in global strategic alliances: AMRAD and the Australian biomedical industry. Competitiveness Review, 10(1), pp. 25-44.

Jeżak, J. (2016). Rozwój przedsiębiorczości rodzinnej w Polsce na tle tendencji światowych [Development of Polish family firms in the context of global trends]. Przeglad Organizacji, 4, pp. 52-59.

Jeżak, J., Popczyk, W. and Winnicka-Popczyk, A. (2004). Przedsiębiorstwo rodzinne: Funkcjonowanie i rozwój [Family business: Operation and development]. Warszawa: Difin, pp. 23-24, 26. 
Kałużna, H. (2009). Firmy rodzinne w XXI wieku - specyfika i sukcesja [Family businesses in the 21st century - specificity and succession]. Ekonomika $i$ Organizacja Gospodarki Żywnościowej, 75, p. 56.

Kets de Vries, M.F. (1993). The dynamics of family controlled firms: The good and the bad news. Organizational Dynamics, 21(3), pp. 59-71.

Klimek, J. (2014). W rodzinnej firmie. Powstanie, rozwój, zagrożenia i szanse [In the family business. Establishment, development, threats and opportunities]. Warszawa: Wydawnictwo Menedżerskie PTM.

Klimek, J. and Lipiec, J. (2015). Firmy rodzinne w perspektywie unijnej[Family businesses from the EU perspective]. Unia Europejska.pl, 3(232), pp. 30-37.

Kotlar, J. and De Massis, A. (2013). Goal setting in family firms: Goal diversity, social interactions, and collective commitment to family-centered goals. Entrepreneurship Theory and Practice, 37(6), pp. 1263-1288.

Krappe, A., Goutas, L. and Von Schlippe, A. (2011). The 'family Business Brand': An enquiry into the construction of the image of family businesses. Journal of Family Business Management, 1(1), pp. 37-46.

Kuszaj-Milewska, M. (2012). Instrumenty informatyczne szansą dynamicznego rozwoju CSR [IT instruments - an opportunity for the dynamic development of CSR]. In: W. Kowalczewski, ed., Ewolucja czy rewolucja? Czas przemian czas wyzwań: zmiany $w$ teorii $i$ praktyce zarzadzania [Evolution or revolution? A time of change - a time of challenges: Changes in management theory and practice], 1st ed. Warszawa: Wydawnictwo Pret, p. 208.

Kowalewska A., ed. (2010). Firmy rodzinne $w$ polskiej gospodarce - szanse $i$ wyzwania [Family businesses in the Polish economy - opportunities and challenges]. Warszawa: Polska Agencja Rozwoju Przedsiębiorczości, p. 30.

Lansberg, I.S. (1983). Managing human resources in family firms: The problem of institutional overlap. Organizational Dynamics, 12(1), pp. 39-49.

Lee, Y.G. and Marshall, M.I. (2013). Goal orientation and performance of family businesses. Journal of Family and Economic Issues, 34(3), pp. 265-274.

Levering, R. and Moskowitz, M. (1993). The ten best companies to work for in America. Business and Society Review, 85(1), pp. 26-38.

Lewandowska, A. (2013). Identyfikacja kluczowych wartości jako istotny element konkurowania firm rodzinnych [Identification of core values as an essential element of the competition of family businesses]. [online]. Available at: https://docplayer.pl/1487291-Adrianna-lewandowska-identyfikacja-kluczowych-wartosci-jako-istotny-element-konkurowania-firm-rodzinnych.html [Accessed 15 July 2020].

Lewandowska, A. (2015). Kody wartości, czyli jak efektywnie przejść przez sukcesje $w$ firmie rodzinnej [Value codes or how to effectively pass through succession in a family business]. Poznań: Lewandowska i Partnerzy.

Lewandowska, A., Więcek-Janka, E., Hadryś-Nowak, A., Wojewoda, M. and Tylczyński, Ł. (2016). Firma rodzinna to marka [A family business is a brand]. Poznań: Instytut Biznesu Rodzinnego.

Long, R.G. and Mathews, K.M. (2011). Ethics in the family firm: Cohesion through reciprocity and exchange. Business Ethics Quarterly, 21(2), pp. 287-308.

Marjański, A. (2012). Specyfika firm rodzinnych [Specificity of family businesses]. In: Firma $w$ rodzinie czy rodzina $w$ firmie. Metodologia wsparcia firm 
rodzinnych [Business in the family or family in the business. Methodology of support for family businesses], 1st ed. Warszawa: Polska Agencja Rozwoju Przedsiębiorczości, pp. 30-38.

Marjański, A. (2012). Sukcesja jako wyróżnik przedsiębiorstwa rodzinnego [Succession as a distinguishing feature of the family business]. Przedsiębiorczość $i$ Zarzadzanie, 13(7), pp. 9-27.

Martini, L.K.B., Suardana, I.B.R. and Dwijendra, N.K.A. (2017). Implementation of values on family company succession in Bali Province. Indonesia. Journal of Sustainable Development, 10(4), pp. 75-82.

Martyniuk, O. (2013). Funkcjonowanie polskich przedsiębiorstw rodzinnych w okresie spowolnienia gospodarczego [The functioning of Polish family businesses during the recession]. Zarzadzanie i Finanse, 2(2), pp. 241-254.

Martyniuk, O. and Gierusz, A. (2016). Location behavior of family firms evidence of Poland. Przedsiębiorczość i Zarzadzanie, 17(6), pp. 283-295.

Martyniuk, O. and Stańczak-Strumiłło, K. (2012). Determinanty wartości przedsiębiorstwa rodzinnego [Determinants of family business values]. Zeszyty Naukowe Uniwersytetu Szczecińskiego, 737, pp. 137-154.

Mazur-Wierzbicka, E. (2014). Specyfika realizacji koncepcji społecznej odpowiedzialności biznesu w przedsiębiorstwach rodzinnych [Specificity of the implementation of the concept of corporate social responsibility in family businesses]. Przedsiębiorczość i Zarzadzanie, 15(7), pp. 232-234.

Miller, D. and Le Breton-Miller, I. (2006). Family governance and firm performance: Agency, stewardship, and capabilities. Family Business Review, 19(1), pp. 73-87.

Miller, D., Le Breton-Miller I. and Scholnick, B. (2008). Stewardship vs. stagnation: An empirical comparison of small family and non-family businesses. Journal of Management Studies, 45(1), pp. 51-78.

Moog, P., Mirabella, D. and Schlepphorst, S. (2011). Owner orientations and strategies and their impact on family business. International Journal of Entrepreneurship and Innovation Management, 13(1), pp. 95-112.

Morris, M.H., Williams R.O., Allen J.A. and Avila R.A. (1997). Correlates of success in family business transitions. Journal of Business Venturing, 12(5), pp. 385-401.

Murray, B. (2016). The succession transition process: A longitudinal perspective. Family Business Review, 16(1), pp. 17-33.

Nalazek, A. (2012). Marka firmy rodzinnej [Family business brand]. In: Firma w rodzinie czy rodzina $w$ firmie. Metodologia wsparcia firm rodzinnych [Business in the family or the family in business. Methodology of support for family businesses], 1st ed. Warszawa: Polska Agencja Rozwoju Przedsiębiorczości, pp. 63-65.

Niehm, L.S., Swinney, J. and Miller, N.J. (2008). Community social responsibility and its consequences for family business performance. Journal of Small Business Management, 46(3), pp. 320-332.

Olkiewicz, M. (2013). Jakość zasobów ludzkich determinantą procesu sukcesji [The quality of human resources as a determinant of the succession proces]. Przedsiębiorczość i Zarzadzanie, 14(6), 1, pp. 57-71. 


\section{Reputation of Family Businesses}

Paliwoda-Matiolańska, A. (2009). Odpowiedzialność społeczna w procesie zarzadzania przedsiębiorstwem [Social responsibility in the enterprise management process]. Warszawa: Wydawnictwo C.H. Beck, p. 53.

Parada, M.J., Nordqvist, M. and Gimeno, A. (2010). Institutionalizing the family business: The role of professional associations in fostering a change of values. Family Business Review, 23(4), pp. 355-372.

Popczyk, W. (2014). Kapitał społeczny w firmach rodzinnych. Struktura i mechanizm kreowania kapitału rodziny [Social capital in family businesses. The structure and mechanism of creating family capital]. Przedsiębiorczość $i$ Zarzadzanie, 15(7), pp. 133-145.

Popławski, W. (2003). Finansowa pomoc publiczna dla matych i średnich przedsiębiorstw. Toruń: Instytut Biznesu w Kaliszu, p. 125.

Pukall, T.J. and Calabrò, A. (2013). The internationalization of family firms: A critical review and integrative model. Family Business Review, 27(2), pp. 103-125.

Randøy, T. and Goel, S. (2003). Ownership structure, founder leadership, and performance in Norwegian SMEs: Implications for financing entrepreneurial opportunities. Journal of Business Venturing, 18(5), pp. 619-637.

Redding, S.G. (1990). The Spirit of Chinese Capitalism. Berlin: De Gruyter.

Reid, R.S. and Adams, J.S. (2001). Human resource management - a survey of practices within family and non-family firms. Journal of European Industrial Training, 25(6), pp. 310-320.

Safin, K. (2007). Przedsiębiorstwa rodzinne - istota i zachowania strategiczne [The essence and strategic behavior of family businesses]. Wrocław: Wydawnictwo Akademii Ekonomicznej im. Oskara Langego.

Sciascia, S, Mazzola, P., Astrachan, J.H. and Pieper, T. (2010). The role of family ownership in international entrepreneurship: Exploration nonlinear effects. Small Business Economics, 38(1), pp. 15-31.

Shanker, M.C. and Astrachan, J.H. (1996). Myths and realities: Family businesses' contribution to the US Economy - A framework for assessing family business statistics. Family Business Review, 9(2), pp. 107-119.

Sharma, P., Chrisman, J.J. and Chua, J.H. (2003). Succession planning as planned behavior: Some empirical results. Family Business Review, 16(1), pp. 1-15.

Smyczek, S. and Gola, J. (2011). Zjawisko agencji w firmach rodzinnych [The phenomenon of agency in family businesses]. In: A. Marjański, ed., Firmy rodzinne - determinanty funkcjonowania i rozwoju [Family businesses - determinants of functioning and development], 1st ed. Łódź: Wydawnictwo Społecznej Wyższej Szkoły Przedsiębiorczości i Zarządzania, pp. 267-280.

Starnawska, M. and Popowska, M. (2015). O mniej lub bardziej słodkim cukrze, czyli kilka uwag o odpowiedzialności społecznej firm rodzinnych i przedsiębiorstw społecznych [About more or less sweet sugar, i.e. a few remarks on social responsibility of family businesses and social enterprises]. Ekonomiczne Problemy Ustug, 116, pp. 180-190.

Stawicka, E. (2010). Firmy rodzinne jako przykład przedsiębiorstw zarządzanych przez wartości, ich sens i znaczenie [Family businesses as an example of enterprises managed by values, their sense and meaning]. Zeszyty Naukowe 
Szkoły Głównej Gospodarstwa Wiejskiego w Warszawie, 10(25), pp. 110-118.

Stawicka, E. (2011). Społeczna odpowiedzialność w firmach rodzinnych [Social responsibility in family businesses]. Przedsiębiorczość i Zarzadzanie, 12(7), pp. 281-290.

Stępniewska, A. (2013). Elementy procesu sukcesji $w$ wybranych polskich przedsiębiorstwach rodzinnych [Elements of the succession process in selected Polish family businesses]. Gdańsk: Wydawnictwo Politechniki Gdańskiej.

Stradomski, M. (2010). Finansowanie obce firm rodzinnych na rynku niedoskonatym [External financing of family businesses on the imperfect market]. Warszawa: Polskie Wydawnictwo Ekonomiczne, pp. 148-153.

Sułkowski, Ł. (2004). Organizacja a rodzina. Więzi familijne $w$ życiu gospodarczym [Organization and family. Family ties in economic life]. Torun: TNOiK, Torun 2004, p. 99

Swinth, R.L. and Vinton, K.L. (1993). Do family-owned businesses have a strategic advantage in international joint ventures?. Family Business Review, 6(1), pp. 19-30.

Szczepańska-Woszczyna, K. (2018). (Nie)zmienność wartości w zarządzaniu przedsiębiorstwami rodzinnymi $\mathrm{w}$ procesie sukcesji i cyklu ich życia [(Un) variability of values in family businesses management in the process of succession and their life cycle]. Przeglad Organizacji, 10, pp. 10-17.

Szczepańska-Woszczyna, K. and Kurowska-Pysz, J. (2016). Sustainable business development through leadership in SMEs. Economics and Management, 8(3), pp. 57-69.

Tagiuri, R. and Davis, J.A. (1996). Bivalent attributes of the family firm. Family Business Review, 9(2), pp. 199-208.

Tàpies, J. and Fernández Moya, M. (2012). Values and longevity in family business: Evidence from a cross-cultural analysis. Journal of Family Business Management, 2(2), pp. 130-146.

Timothy, G., Habbershon, T.G. and Williams, M.L. (1992). A resource-based framework for assessing the strategic advantages of family firms. Family Business Review, 12(1), pp. 1-25.

Thomas, J. and Graves, C. (2005). Internationalizing the family firm as a demonstration of an entrepreneurial culture. Journal of Small Business and Entrepreneurship, 17(2), pp. 91-113.

Van Dijk, T.A. (2009). Discourse studies: A multidisciplinary introduction. London: SAGE Publication.

Van Riel, C.B.M. and Fombrun, C.J. (2007). Essentiasls of corporate communication. London: Routledge.

Wach, K. (2014). Familiness and born globals: Rapid internationalisation among Polish family firms. Journal of Intercultural Management, 6(3), pp. 177-186.

Ward, A. and Smith, J. (2003). Trust and mistrust. Radical Risk Strategies in Business Relationships. Chichester: John Wiley \& Sons.

Ward, J.L. (1988). The special role of strategic planning for family businesses. Family Business Review, 1(2), pp. 105-117.

Weber, M. (2002). Gospodarka i społeczeństwo: Zarys socjologii rozumiejacej [Economy and society: The outline of understanding sociology]. Warszawa: Wydawnictwo Naukowe PWN, p. 181. 


\section{Reputation of Family Businesses}

Whiteside, M.F. and Brown, F.H. (1991). Drawbacks of a dual systems approach to family firms: Can we expand our thinking? Family Business Review, 4(4), pp. 383-395.

Więcek-Janka, E. (2013). Wiodące wartości w zarządzaniu przedsiębiorstwami rodzinnymi [Leading values in family business management]. Poznań: Wydawnictwo Politechniki Poznańskiej.

Więcek-Janka, E. and Lewandowska, A. (2017). Model pięciu poziomów definiowania przedsiębiorstw rodzinnych [Five-level Model for Defining Family Business]. Przedsiębiorczość i Zarzadzanie, 18(6), pp. 159-176.

Zahra, S.A. (2018). Entrepreneurial risk taking in family firms: The wellspring of the regenerative capability. Family Business Review, 31(2), pp. 216-226.

Zellweger T.M., Kellermanns, F., Eddleston, K.A. and Memili E. (2012). Building a family firm image: How family firms capitalize on their family ties. Journal of Family Business Strategy, 3(4), pp. 239-250. 


\section{The Concept of Family Business Reputation Management}

\subsection{Principles of Reputation Management}

Nowadays, reputation management is becoming increasingly difficult. The number of information nodes that shape opinions about companies is increasing successively. The Internet has shifted the burden of power over key information resources to other decision-making centres. They do not have a direct influence on them, but they are becoming increasingly audible, although not always better informed. This kind of infodemic prevents one from forming an opinion about the company. It is potentially dangerous because it can lead to the spread of various false opinions, the erosion of trust, and consequently a decline in reputation. Recently, the capacity for action and impact of small communication groups called network assassins have also increased significantly. Their voices are gaining disproportionately in importance, as they are credited with representing social interest and assume that they must be heard. Reputations are born and die in a highly dispersed environment. The following CSR measures should therefore be most important to the company:

- addressed to employees (employee relationships);

- for the natural environment (environment);

- market-oriented (fair market practices);

- addressed to society (social commitment and development) (Paliwoda-Matiolańska, 2009; Baron, Tang, 2009).

In line with the stakeholder theory, a long-term plan for building transparent, lasting and sustainable relationships with all stakeholders must also be taken into account in modern business. This applies to owners, employees, customers, suppliers, co-operators, as well as local and regional communities and the government (Hąbek, 2009; Rodriguez, Ricart, 2002). Still, current values which are desirable to various groups of stakeholders remain: 
- in the case of customers - high quality products/services, low price of products/services, innovation and uniqueness of products/services, fair treatment, convenience/availability;

- $\quad$ shareholders - high share price, dividend payment at a high level;

- suppliers - stability of cooperation, satisfactory level of market prices, reasonable payment deadlines, financial stability, volume of turnover;

- employees - high salaries, employment security, social welfare, adherence to labour rights, respect, development opportunities;

- regulators - engaging in social, charitable and educational projects conducted/ recommended by regulators;

- the local community - the company's activity in the sphere of social responsibility;

- journalists - equal treatment, transparency, response speed, professionalism;

- pressure groups - achieving their own objectives;

- partners/allies - preferential terms of cooperation, priority in cooperation (Susniene, 2008; Baron, Markman, Bollinger, 2006).

Reputation management is the permanent performance of two tasks: trying to be more liked and trying to be less hated. M. Sandman is a proponent of the thesis that if you have a good reputation, you will be endowed with the presumption of innocence in a crisis situation, while if you have a bad reputation, you will face a presumption of guilt (Sandman, 2011). Examining the reputation of domestic companies, the German monthly "Manager Magazine" (Deutschlands Beste Wirtschafts-Prufer, 2018; Business Destination Germany, 2018), refers to ten reputation indicators, namely the quality of management, innovation, corporate social responsibility, willingness to communicate with the environment, product quality, financial and economic stability, employee orientation, growth rate, the attractiveness of management and the internationalization of the company.

Other approaches to the process of corporate reputation management appear in the relevant literature. Three blocks are distinguished, namely crisis management, issues management and actions in the area of social responsibility (Majchrzak, 2015; Baron, Tang, 2009).

G. Davies and L. Miles take the view that companies can manage their reputation and are convinced of the emergence of the business function responsible for this area (Davies, Miles, 1998). A different opinion is expressed by Mahon (2002), Wartick (1992), and G.R. Dowling (Barnett, Jermier, Lafferty, 2006; Żemigała, 2012). They believe that it is people (stakeholders) who control corporate reputation, so companies cannot manage it. They point to another approach, where the most important element in reputation management is to understand the impact that individual stakeholder groups have on it. A good reputation is a valuable and rare resource, difficult to imitate and substitute, which can 
be a source of lasting competitive advantage for the company (Dąbrowski, 2010). It also generates various types of supporting activities of stakeholders and increases the value of the company's intangible assets. According to G.R. Dowling, a good reputation increases the readiness of new buyers to choose the company's offer, leading to stronger customer satisfaction, closer identification with the company and an increased level of loyalty. On the other hand, it reduces buyers' sensitivity to price increases, which allows companies with a better reputation to obtain a higher price premium than the competition (Dowling, 2006). As a result, such entities achieve better financial performance and are able to maintain it in the longer term (Eberl, Schwaiger, 2005). As C.E. Carroll puts it (Carroll, 2013), corporate reputation and its management can be understood as often repeated information about the nature of a company characterized by low volatility. In addition, E. Wood and I. Somervill emphasize its evolutionary character and historical dimension, which seems highly transparent and facilitates the separation of the ranges of reputation management at its various stages (Wood, Somerville, 2016).

A proper assessment of the status of reputation allows for the adoption of an appropriate plan to improve it. On the other hand, Fombrun and Van Riel (2004) stress that companies with the best reputation conduct all their activities based on the following principles of effective reputation management:

- the principle of focus (or the principle of being visible) - conducting activities and communication around one main, basic message;

- the principle of distinctiveness - achieving a distinguished position in the minds of stakeholders;

- the principle of identity - conducting activities in accordance with accepted identity principles;

- the principle of transparency - a transparent way of conducting activities; transparency requires active communication;

- the principle of consistency - consistent conduct of activities and communication towards all stakeholders.

In fact, reputation management is a more complex problem extended over time, which requires a permanent search for answers to a large number of questions arising from the company-stakeholder relationship (Kończak, Bylicki, Borkowska, 2016). A list of tasks related to shaping reputation may be helpful here:

1. Make sure that people who adore you now, adore you even more.

2. Make sure that people who adore you now, do not adore you less.

3. Make sure people who adore you a little, adore you more.

4. Make sure that people who adore you now do not stop doing so. 


\section{Family Business Reputation Management}

5. Make sure that people who neither adore you nor hate you now begin to "adore you a little."

6. Make sure that people who adore you a little and hate you a little now, start "to adore you more."

7. Make sure that people who adore you a little and hate you a little now, stop hating you.

8. Make sure that people who now neither adore nor hate you, do not hate you.

9. Make sure that the people who hate you now begin to hate you less.

10. Make sure that people who hate you a little now do not hate you more.

11. Make sure that people who hate you very much begin to hate you less.

12. Make sure that people who hate you very much do not hate you even more (Sandman, 2011; Kubiak, 2012; Zsidisin, Ragatz, Melnyk, 2005).

C. J. Fombrun and C. B. Foss believe that people justify their feelings towards companies with one of 20 attributes, which have been grouped into six dimensions:

- emotional motifs: the extent to which the company is liked, admired and respected,

- products and services: perception of the quality, innovation, value and reliability of the company's products and services,

- financial result: perception of the company's profitability, prospects and risks,

- vision and leadership: the extent to which the company has a clear vision and strong leadership,

- work environment: seeing how well the company is managed, and how it acts for its employees,

- social responsibility: assessment of the company in contact with the community, employees and the environment.

When building an instrument for measuring reputation with the use of the attributes presented above, the authors formulated the following principles related to reputation management:

1. The principle of distinction - a strong reputation arises from the company having a distinguished position in the industry in the minds of the recipients. Some examples are Intel and AMD, two leading manufacturers of integrated circuits and microprocessors. Both products offer comparable quality, speed and power. However, Intel dominated AMD in the minds of computer buyers. Intel owes its reputation not to the quality of its products, but to the "Intel 
Inside" campaign, which defined these products as basic components that "drive" better computers. "Intel Inside" has become a determinant of the quality and reliability of the equipment. Intel's campaign made it possible to transform an integrated circuit into a product and brand that determined the quality of the entire computer. Moreover, with the rapid recognition of the "Intel Inside" slogan, its owners took over a dominant role in the value chain and made computer manufacturers dependent on their components. This campaign has built Intel's reputation as a guarantor of excellence for the end user. Intel found a way to stand out from the pack.

2. The principle of focus/concentration - a strong reputation arises when companies concentrate their activities and communicate around one main theme. Examples include family businesses such as Inglot, which has become a global leader in cosmetics; Suempol, which is today the third-largest salmon producer in the world; and Solaris, which is Europe's most recognizable tram manufacturer. These companies gained public confidence by basing their campaigns on credibility.

3. The principle of consistency - a strong reputation arises when companies are consistent in their activities and communication with all groups of recipients. Research confirms that companies which have organized and integrated their activities and communication between individual organizational members who fulfil specific tasks (functions) achieved a stronger reputation. Companies with a weaker reputation were characterized by separate relationships with individual stakeholder groups, as well as the fragmentation of initiatives and communication.

4. The principle of identity - a strong reputation arises when companies act in a manner consistent with accepted identity principles. Information manipulation and exaggeration is the opposite of reputation building. Over time, all efforts to manipulate the company's external image, which are based solely on advertising and public relations, fail when they are not based on corporate identity.

5. The principle of transparency - a strong reputation arises when companies are transparent in conducting their activities. Transparency requires communication. Research confirms that companies with a stronger reputation are more visible in all media. They reveal more information about themselves and willingly initiate a dialogue with stakeholders (Fombrun, Foss, 2001).

Based on the literature review above, one more can be added to the catalogue of principles related to reputation management:

1. The principle of filtering signals and responses - inconsistency, or even a gap between the internal and external images of what is 
happening to the company, often arises. If the company and its employees do not see signals adversely affecting reputation, they may not respond in time to prevent it. When company managers receive negative signals from stakeholders which are not taken seriously, this lack of attention can be interpreted as ignoring information.

The reputation of a family business is tantamount to the good name of its owner or owners. In this context, development of and skillful care for reputation is of particular importance and should be as significant for the family business as the introduction of further products or winning new customers.

\subsection{Operationalization of Family Business Reputation Management}

The operationalization of family business reputation management is a research effort to identify the partial scientific problems which are relevant in terms of family business reputation management itself, but also to present them in a convention enabling them to be resolved.

It is worth briefly recalling, by referring to the discussion in previous chapters, that corporate reputation is one of the most important strategic resources (Ferguson, Deephouse, Ferguson, 2000). The benefits of a good reputation include competitive advantage, customer loyalty, acquiring and retaining employees, acquiring partners, expansion into foreign markets, and expanding the value of intangible assets (Dąbrowski, 2010). In fact, corporate reputation is related to its ability to maintain a competitive advantage (Roberts, Dowling, 2002). The difficulty in strengthening and developing a competitive advantage is due to the difficulty of improving one's reputation. In view of the benefits of a positive reputation on the one hand and difficulties in improving reputation on the other, companies should make every effort to build and maintain their reputation using systemic reputation management solutions.

At the same time, as has already been noted, reputation is highly elusive, amorphous, sensitive, very difficult to maintain and it is extremely difficult to measure and express in the form of monetary units. The difficulty in determining the value of return on investment with regard to the company's expenditure on managing a potential loss of reputation and the determination of the loss suffered by the company as a result of a reputation-damaging event often leads to a situation when reputation management recedes to the background in favour of more measurable factors. As regards family businesses, the cost of losing corporate reputation enhances the deterioration of the family's image and the name of the founding family, which can have a value-related, economic and emotional dimension. 
Reputation management was introduced to management sciences by Davies and Miles (1998), followed by Chun (2005), who claimed that the starting point for effective reputation management is to understand and care for three elements: identity (who we are), identity presented (how we present ourselves) and image (how others see us).

G. Honey, on the other hand, emphasizes six aspects of reputation which allow for the understanding of its essence and the management thereof. They relate to:

- relative design - reputation is the assessment of a company by different stakeholder groups with different needs and expectations, so their views on the same entity may be extremely different;

- attributed uniqueness - reputation can be built based on unique features, values or aspects of activity, valued by a given group of stakeholders;

- comparison-based perception - reputation is based on comparing the enterprise to different benchmarks: standards, values, norms, industry averages, competitors, ideas or stereotypes;

- unintended consequences - reputation is the result of the impact of various factors that the company cannot shape or control;

- the result of a sequence of events - reputation cannot be built overnight, but results from a series of events and actions, while real actions are more important than declarations;

- emotional influence - reputation is based on emotional responses and interactions, and its foundation is created by universal values such as credibility, integrity, trust and responsibility (Honey, 2009).

Reputation depends on the value and quality of the company's previous activities (Podolny, Phillips, 1996), and it is important that the company considers the impact of its current activities on its future reputation. Any strategic choice made by the company will not only have a direct impact on the change of its competitive position, but will also affect its reputation. J. Klimek believes that the reputation management process consists of identifying opportunities to improve the opinions of stakeholders about the company and the factors which threaten a good reputation, planning actions necessary to strengthen or protect reputation, monitor reputation, measure reputation risks and choose one of the three risk management strategies (risk avoidance, risk control and risk mitigation) (Klimek, Żelazko, 2014). Threats to the reputation of a family business include:

- $\quad$ succession - a family business management system often operates based on informal relationships; the problem with finding a suitable candidate for the management position, the process of succession conducted without preparation, day to day, or handing managerial 


\section{Family Business Reputation Management}

responsibilities over to a person who is unwilling to accept such responsibility, may disrupt the relationship; by planning for succession, the company will avoid conflicts, as the successor will have time to prepare to assume the responsibilities of management, and the company's employees will adjust to changes and become accustomed to the new manager;

- a one-person management model and the concentration of management decisions - in the event of an emergency, it will expose the company to decision paralysis, confusion and helplessness;

- conflicts arising as a result of the intertwining life of a company and family, management of salaries, transfer of negative emotions and intergenerational dialogue.

The analysis of the extant literature leads to the conclusion that there is no single universal standard of corporate reputation management. However, its core components can be identified, namely:

1. constitutional relationships: defining stakeholder groups; identifying behaviour in relation to their key stakeholder groups; developing standards according to which they design their practices vis-à-vis stakeholders;

2. reputation-building practices: business strategies and systems used to build reputation and relationships with key stakeholder groups;

3. organizational issues: the ways in which companies manage their reputation; having a "reputation-building strategy".

It also includes the following processes: defining the identity and identifying the need to express it by means of actions targeting individual stakeholder groups, which reflect the obligation to exceed standards both at work and outside it; actions that companies take to transmit their identity to key stakeholders and influence their perception; continuous listening to determine whether its message has been accepted and to reduce the gap between the perception of stakeholders and the perception of corporate identity (Fombrun, Rindova, 1998). Reputation is a concept that, in order to be implemented over a long period of time, must be linked to the company's fundamental strategies and objectives, its mission, values and vision.

Reputation management, as emphasized by Szwajca (2016), should be unnoticed, discreet and subtle, and this process can be presented as a closed cycle of four essential stages, namely shaping corporate identity, stakeholder relationship management, fulfilling the expectations of stakeholders, and communication and developing dialogue with stakeholders.

Reputation management, as K. Majchrzak also notes, is a process implemented over time covering the following stages: the assessment of the 
baseline situation, the anticipation of potential threats, the measurement of the likelihood of an event likely to affect reputation, the determination of the organization's response to risk, and control and simulation of events which affect reputation (Majchrzak 2009; Figiel, 2013).

In the first stage, it is vitally important to identify company-stakeholder relationships. This involves attributing responsibility to business leaders, identifying stakeholders, and defining the criteria for assessing the company's weaknesses and strengths. It is also important to determine its position in relation to competitors and to assess the current level of reputation (Jabłoński, 2013; Szumniak-Samolej, 2013). The subsequent step is to identify potential events that may affect the risk of loss of reputation. They can be grouped according to the probability of their occurrence or according to the principles developed by the PWC in the COSO-ERM model (COSO, 2017). However, there is no good or bad way to categorize events, as each of them has different goals. It is important that these actions are taken. A variety of techniques are useful in this process, e.g. brainstorming, surveys, analyses, interviews and focus groups (COSO, 2017; Antonucci, 2016). The third stage in the reputation management process concerns the measurement of the likelihood of risk occurrence: small, moderate or probable (Makowicz, 2011; Przywecki, Słabosz, Ziomko2013). The next step is to determine the organization's response to risk. This may take the following forms: avoidance (non-involvement in activities that may increase the threat of risking one's reputation), acceptance (recognition of certain risks associated with business), verification (checking the parties' ability to act in a crisis situation) and reduction (minimizing identified risk areas in the form of preventive and control measures) (Urbanowska-Sojkin, 2013; Gregorczyk, 2013). The fifth stage of reputation management consists of controlling and simulating events affecting it (Blajer-Gołębiewska, 2017).

Family businesses undoubtedly have unique features that enable them to play a considerable role in economies around the world. The issue is the means by which to assess their uniqueness and combine it with a market advantage. These features are important for defining the concept of reputation management.

Grant (1991) proposes a model which describes the relationship between resources and competitive advantage in reputation management, which he believes can be easily adapted to family businesses. It analyses the links between the internal characteristics of companies and results, provides the possibility of better defining the competitive advantages of family businesses and, consequently, transforming the features that demonstrate the uniqueness of the company into a strategic resource.

Intangible assets are at the heart of the resources of a family business and they include technology, brand, reputation, corporate culture or a value system. Resources affect the perception of the company by stakeholders, who, as has already been mentioned, represent the success of the 


\section{Family Business Reputation Management}

company both today and in the future. In a family business, it is the internal factors that are crucial to functioning. According to the resource-based view, companies with unique resources are capable of developing strategies to achieve competitive advantages. For example, the building of a good reputation is influenced by the owner/leader of a family business. If we believe that family managers determine a competitive advantage, the following must be defined: (a) what kind of resources they create, (b) under which conditions they add value, (c) what opportunities the company gains as a result of having this resource, (d) what potential they have for a sustainable competitive advantage, (e) what strategies can be used to develop their strengths and (f) what objective measures must be used to assess the efficiency of this resource. In this case, a resource can be classified as rare and valuable if it enables the company to develop or implement strategies that improve its efficiency and effectiveness.

Reputation building involves dialogue with stakeholders and satisfying their needs. According to E. Schreiber, the following variables which affect the level of reputation of the company are important to stakeholders:

- corporate culture, social responsibility, the ability to attract talented workers to the organization, and business ethics,

- communication, sponsorship of important events and quality of communication,

- market leadership, distinguishing the mission and vision of the company,

- brand recognition and superiority,

- efficiency of management, investment in $\mathrm{R} \& \mathrm{D}$, global competitiveness, a strong financial position and a dominant market position in the domestic market,

- customer orientation, offering products and services of the highest quality at reasonable prices, and fair and reliable treatment of the customer (Schreiber, 2002).

Companies that wish to manage their reputation seriously should make it an integral part of the corporate culture and value system (Figiel, 2011). The value of reputation should be spread among employees as a core element of the identity of a company, and each employee should be aware of how his/her actions translate into corporate reputation. Reputation building cannot be identified with corporate advertising, which lacks reputation-building activities among stakeholders.

Effective reputation management is a condition for responding to changes in the environment. The phenomenon of active inertia is the belief that acting the same way as before, even if it has led the company to success, will ensure success in the future. In this way, businesses 
become static and do not respond to changes in the environment, while reputation begins to weaken after some time. This situation in particular threatens family businesses that pursue stabilization at all costs in order to ensure the long-term functioning of the company. The reason for the loss of reputation may also be the inability to define the core competencies of a company. Another condition for effective reputation management is consistency between the promise made by the company and the actual experience of the stakeholders in contact with it, as well as consistency and continuity of communication over a long period of time.

\subsection{The Concept of Family Business Reputation Management}

A concept is understood and described as a uniform and consistent methodological course of research, which determines a logical way to solve the scientific problem addressed, including the methods applied at the various stages specified in the procedure. The concept of examining the reputation of family businesses, therefore, includes all the components of the concept thus defined, taking into account the structure of the scientific problem addressed here. In view of the theoretical findings so far, our attention will be focused on identifying the problems that may constitute areas for building the reputation of family businesses. At the same time, the authors' agreement on the importance of reputation as a value and resource for the company allows for the assumption that informed reputation management will have an impact on the development of the family business.

The analysis of the extant literature, which is presented in chapters two and three, does not give clear indications as to the catalogue of individual components that are part of individual problems. Empirical research is required to resolve this issue, and can be implemented using different research strategies (a qualitative, quantitative or integrating approach) selected appropriately for research objectives and problems (Chełpa, 2004).

The scientific problem raised here requires the definition of an appropriate concept of studying the reputation of family businesses. In order to achieve reliable results on the problem of family business reputation management, the induction method will be used. According to inductionism, new scientific statements and the testing thereof in empirical sciences is achieved by means of the inductive generalization of facts (Lisiński, 2016), adopting the following principle: first observation, then generalization. This process consists of shifting from individual phenomena or empirical processes obtained by observation, to their justification and construction of a theory to determining its value. The entire research process and all activities undertaken therein are subordinated to the induction generalization of facts as a way of building theory (Lisiński, 2016; Babbie, 2003). 
Management sciences, classified as empirical sciences (Lisiński, 2016), use both nomothetic and idiographic, i.e. quantitative and qualitative, research (Chełpa, 2004). S. Chełpa agrees that management, as a science, does not have to develop its own original methodology, but rather should use eclecticism to allow the use of a research method that will solve the problem (Wesołowski, 2007; Sułkowski, 2004). W.J. Wesołowski believes that modern management is based on quantitative methods and theories proven by deterministic methods, causing it to take on the characteristics of science; However, this approach to research raises debate. L. Sułkowski describes this critically as a "mythology of scientism" in the management sciences, resulting in persistent attempts to apply mathematical models "and preferences for representative methods statistically manifesting in the belief that only random sample-based research can lead to generalization (....)". At the same time, it introduces the value of the qualitative methods used in social sciences. Such a specificity of management means that the knowledge generated does not have the character of absolute and timeless truth. Instead, according to S. Chelpa, the science of management creates (...) fragmentary theories, referring to certain conditions (...) that truly describe and explain reality, but only in certain areas and in certain parts of time and situations (Ćwiklicki, 2010).

The nature of creating a theory in management, in which induction and qualitative research should be taken into account, is inscribed in the Grounded Theory method developed by B.G. Glaser and A.L. Strauss in 1967 , assuming that the research process is based on building an increasingly general theory based on systematically collected empirical data (Glaser, Strauss, 2009). According to the authors, a theory can only be formulated after conducting empirical research based on which some assumptions are formulated and verified in the course of further research. K. Konecki explains that building a theory according to this methodology is a process. Theory emerges here, during systematic field research, from empirical data, which directly relate to the observed part of social reality. Hypotheses, concepts and properties of concepts are built during empirical research and during research they are modified and verified. Thus, building the theory is closely related to the long-term research process itself (Konecki, 2000). However, it is not possible to build and develop a theory without further reference to the sphere of practical activity, which ultimately determines the value of the theory or indicates a lack thereof. In this way, a kind of feedback is identified between the sphere of practical activity and theory (Lisiński, 2016).

Taking into account, on the one hand, the identification of key elements of family business reputation management and, on the other hand, the methodological assumptions that determine the solution of the scientific problem undertaken (an induction method and the Grounded Theory method) - but also the previously discussed proposals for reputation management (D. Szwajca) and, above all, the structure of the 


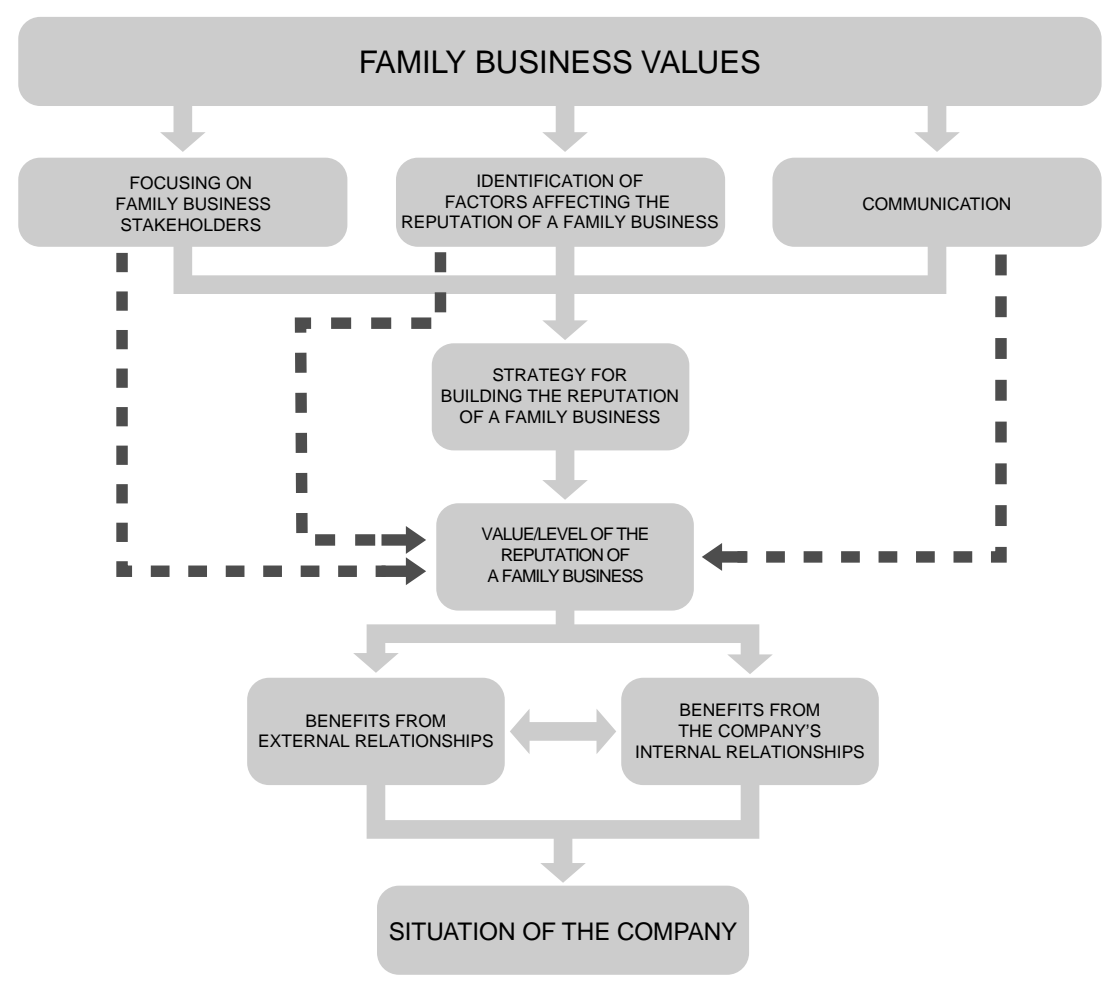

Figure 3.1 Concept of family business reputation management Source: own study.

process of reputation management $-\mathrm{K}$. Majchrzak proposes the original concept of family business reputation management. This concept is presented in Figure 3.1.

The concept of family business reputation management includes key elements and processes. They include:

1. stakeholder relationships, including the definition of stakeholder groups, the knowledge of expectations of individual stakeholder groups, the nature of relationships with key stakeholder groups, and communication standards according to which they design their practices,

2. practices in building reputation, consisting of the company communication system used in building reputation and building relationships with key stakeholder groups,

3. organizing activities, which include partial issues such as: whether and how companies manage their reputation, whether they have a "strategy of building reputation", and who is responsible for it. 
Core processes concern:

1. The awareness of the values and identity of the company and the need to express them through actions aimed at individual stakeholder groups,

2. actions addressed to individual stakeholder groups, which reflect the obligation to exceed standards at work and outside work,

3. communicating their identity to key stakeholders and affecting their perception,

4. listening to determine whether its message has been accepted and to reduce the gap between the perception of stakeholders and the perception of corporate identity.

It was assumed that the starting point for the reputation of a family business was its values. Family business values have a positive impact on the company's orientation towards stakeholders, are shared with stakeholders, and thus affect the knowledge of factors determining reputation and have a positive impact on communication with stakeholders.

Reputation building implies dialogue with stakeholders and responding to their needs, so the company's high stakeholder orientation, knowledge of the company's assessment criteria used by stakeholders that influence reputation and communication with them positively affects the level/value of corporate reputation.

The awareness of the importance of reputation, stakeholder orientation and communication with them underlie the process of building a reputation management strategy. Established and implemented reputation-building strategies are diverse and result in the company's stakeholder orientation, and the knowledge of factors affecting reputation and communication. The reputation-building strategy has a positive impact on the level/value of corporate reputation. It was assumed that the higher the company's orientation in each of the components of corporate reputation management, the better the reputation. This, in turn, affects the situation of the company. The individual components of reputation management will probably translate, to varying degrees, into corporate reputation; therefore, it is worth examining them separately.

Having a good reputation has a positive impact on the areas of activity of the family business and the measurable results of the family business operation. These, in turn, determine the company's market situation.

It is assumed that the activities of family businesses in the area of reputation management are not uniform and allow family businesses to be classified as groups of similar behaviour. The varying intensity of reputation management in these components determines the different structure of this management. 
The adopted concept ignores the impact of external (e.g. changes in economic indicators, changes in the labour market, the activity of the competition and others) and internal factors (e.g. type of corporate culture, the nature of organizational structure, processes, etc.), which certainly affect the dependencies indicated therein.

The assumptions presented so far can be specified as follows:

1. The main areas of reputation building in a family business include the value of the family business, the company's high stakeholder orientation, the knowledge of factors affecting reputation and reputation-building strategy;

2. Family business values have a positive impact on the company's stakeholder orientation, and the knowledge of factors affecting reputation;

3. The company's stakeholder orientation has a positive impact on the level/value of corporate reputation;

4. The knowledge of factors affecting reputation positively affects the level/value of corporate reputation;

5. Differentiation of communication channels affects the individualization of access to different stakeholder groups;

6. Reputation-building strategies possessed and implemented are diversified and result from the company's stakeholder orientation, the knowledge of factors affecting reputation, and the knowledge of factors affecting the loss of reputation;

7. Reputation-building strategy has a positive impact on the level/value of corporate reputation;

8. The level of corporate reputation has a positive impact on the areas of activity of the family business.

Any methodical research concept, in addition to a specific course of research which determines a logical way to solve the scientific problem, also contains the methods used at the various stages specified in this procedure. Attention will now be paid to this issue.

It should be reiterated here that the research process in this work is based on the assumptions of the induction method and the Grounded Theory. A method of literature analysis and review and empirical research (based on qualitative and quantitative methods) was used to achieve the objectives set.

The empirical part of the work, which aims to define the concept of family business reputation management, is based on information from primary sources. As S. Kaczmarczyk explains, the primary research focuses on the characteristics of things, people, events or states, and within this framework, real measurement is made by means of different types of instruments (Kaczmarczyk, 2003). Despite organizational and timerelated difficulties and higher costs than in secondary studies, qualitative 
research methods and techniques are used which make it possible to obtain information which accurately reflects the problem analyzed and presented in the form and layout desired by the researcher. This information is the main source of knowledge in cases where new issues that have not been previously studied are considered (Zrałek, 2018).

Quantitative, especially statistical, methods also play an important role in analyzing phenomena and processes in management sciences, and in solving scientific problems. This is due to the fact that there is a limited amount of research where it is possible and appropriate to investigate the entire population. Using a well-chosen research sample and statistical methods, information about the entire surveyed population can be obtained (Maciejewski, 2010). The creation of a theoretical construct and its subsequent operationalization is considered an appropriate method of identifying phenomena in management sciences. Research by means of quantitative methods is seen as being focused on exploration and explaining poorly recognized phenomena and the relationship between them (Dyduch, 2013). The process of quantitative research involves the analysis of the extant literature, the identification of a research gap, the operationalization of variables, the development of a survey questionnaire, the determination of the research sample, the collection of data, the analysis of individual variables and the analysis of the relationship between individual variables, leading to the verification of hypotheses.

Only the fundamental issues raised regarding the concept of family business reputation management will be specified in the description of its basic stages.

\subsection{Stages of Family Business Reputation Management}

\subsubsection{Importance of Value in Family Business Reputation Management}

The starting point for family business reputation management is its values. As already established in earlier parts of the work, it is values and corporate culture that distinguish family businesses from non-family businesses, while they do not differ in terms of structural features such as size, number of employees, revenues, investments and development plans.

The above-mentioned authors of publications in this field agree on the fact that values in family businesses are closely related to different areas of the company's operation; they are a "background" for organizational culture, they determine strategic planning, goal setting and the model of business management, determine the way of making decisions, implementing strategies, strategic alliances, inspire the development and the achievement of best results, and they are part of the recruitment and retention of employees (Aronoff, Ward, 2016; Marjański, 2012; Miller, 
Le Breton-Miller, Scholnick, 2008; Blikle, 2015). It is emphasized that values in family businesses are also important in terms of overcoming current crises, as in times of uncertainty they can ensure continuity of decision-making. In a family business, the value system of a family business is two coexisting dimensions: internal, created by corporate culture, and external, which consists of reputation, renown and the good name of the company.

The core values of the family business also constitute its corporate identity, creating the distinctive attributes of the organization, including corporate culture or unique products. The identity of a family business is built based on values professed by family business owners and successors, and they determine the management model that should ensure its continuity and long-term operation.

One of the features of the family business value system is the pursuit of risk minimization. Family businesses take a long-term perspective of action that enables them to operate under more stable conditions. Other features of the family business value system are the pursuit of independence and following emotion. It is also important that, on the one hand, family businesses are rather closed, for example, to generally understood cooperation with other companies or non-family employees and, on the other hand, are highly sensitive to relationships with local society.

If family, business, individual/cultural, and dignity values are a part and characteristic of family businesses, distinguishing them and determining their competitive advantage, they will also determine all actions related to reputation management.

The following values that may be relevant to family businesses have been identified in a broad review of national and foreign literature related to family business management and by analyzing research findings so far published in this field, namely a good atmosphere, good relationships between family members, the well-being of an employee who is not the owner's family member, experience, heritage and sustainability, company honour, intuition, loyalty, responsibility, entrepreneurship, family reputation, reliability, a coherent image, stability, respect, transparency of activities, honesty towards stakeholders, knowledge, education, common goals, trust, profit, as well as business ethics, the ethical behaviour of board members and employees, innovation, internationalization, reliability, solidity, corporate social responsibility, financial and economic stability, respect for competition, respect for business partners, meeting deadlines, transparency and openness, care for employees, care for the environment, fairness in pricing, uniqueness, the high quality of products and services, high quality management and cost-effectiveness, a high level of customer service and sustainable development. 


\section{Family Business Reputation Management}

\subsubsection{Identification of Reputation-determining Areas}

\section{Focusing on Stakeholders in the Family Business}

In theoretical terms, relationship (Latin relatio - reference to standards, relating to events) means the narration of an eyewitness about the course of an event, points to a relationship between people or social groups (Bańko, 2005), or defines the relationship between organizations (Jackson, 1985; Olesiński, 2010). Today, they underlie the activity and development of each company. Because of their interaction with each other, economic entities initiate various kinds of relationships, the most common of which are between the company and the customer, the company and other companies, or the company and administration units (Danielak, 2012; Burke, Martin, Cooper, 2011). Inter-organizational relationships between companies can be grouped into the following five categories:

1. vertical relationships, which involve suppliers, intermediaries (distributors) and customers;

2. horizontal relationships, which involve competitors, co-operators and various associations/networks;

3. hierarchical relations (headquarters and subsidiaries);

4. personal relationships (which refer to interpersonal relationships, not related to economic interests, e.g. family or friendly relationships);

5. relationships with experts (consultants, specialists) (Werr, Blomberg, Löwstedt, 2009; Penc-Pietrzak, 2016).

In the process of developing relationships with stakeholders, five core steps can be identified, namely partner selection, defining purpose, setting relationship boundaries, creating value and relationship maintenance (Powers, Reagan, 2007). Management theory presents two basic approaches to analyzing the relationship between a company and its environment. In traditional terms, the model of the influence of actors in the environment relates primarily to the relationship between a company with its "owners", whose influence on the operation of the company is dominant or even direct. The main groups of stakeholders based on the traditional model are shareholders, employees, customers and suppliers.

The stakeholder model assumes a much broader view of the social and economic objectives of the company. In management sciences, the concept of stakeholders is relatively new. Usually, instead of the term "stakeholders", phrases such as "interested groups", "interest groups", "actors", "strategic actors", "social partners", and "interested parties" are encountered. The term "stakeholder" was first used in 1963 in a Stanford Research Institute document to define the groups of entities to 
which company owners should be responsible and without the support of which the organization would cease to exist (Downar, Niedzielski, 2006; Kozielski, 2017; Freeman, Phillips, 1995). Today, business management requires effective and efficient stakeholder relationship management.

The literature on economic and management sciences demonstrates that stakeholders are divided into leading stakeholders, contract stakeholders, technical stakeholders and internal stakeholders, including employees, customers, contractors and investors. However, supporting, contextual, institutional and external stakeholders, as emphasized by B. Year, include the representatives of local communities, NGOs, natural environment, media and public administration (Rok, 2013; Szwajca, Gąsiorek, 2015).

A family business operates based on a specific model of internal relationships (at the level of family - owners - employees) and external ones. Stakeholder relationship management requires a strategic approach. In order to be effective, J. Adamczyk proposes to take six stages in this process into account:

- creating a map of stakeholder relationships;

- mapping stakeholder agreements;

- the identification of stakeholders' expectations;

- the determination of the type of stakeholders' authority;

- the construction of the matrix of priorities;

- stakeholder monitoring (Adamczyk, 2009; Paliszkiewicz, 2013).

The ability to appropriately manage relationships between individual stakeholders and knowledge management underlies the company's functioning in the market and its response to current socio-economic events. These values are reflected in the Harvard model, which assumes that human resource management should be based on a critical analysis of situational factors and stakeholders' expectations (Bukowska, 2006; Prahalad, Krishnan, 2010).

The company cooperates with certain stakeholder groups on the market, and the driving force behind this two-sided activity is the desire to achieve synergies, i.e. to create greater value than that which would be obtained by the entities acting individually. A large number of authors, including R.E. Freeman, T. Grzeszczyk and B. Grucza, classify stakeholders as internal stakeholders, who are company members, participate in the implementation of the projects, and directly participate in its success. The second group is external stakeholders; they are not company members and their impact is more representative than direct, but they benefit from its effects. Therefore, the overriding objective of most companies, including family businesses, is to increase value for the owner, and such an achievement is largely due to the delivery of 


\section{Family Business Reputation Management}

appropriate value to all stakeholders. Hence, cooperation between the company and its stakeholders is bilateral in nature - the company has an impact on the value of individual stakeholders, and they in turn affect the value of the company. It is worth noting that individual stakeholder groups assess the company from a different point of view, in terms of their own needs, interests and expectations. A literature-based and practical compilation is presented in Table 3.1.

J. Balmer (International Centre for Corporate Identity Studies) points out that talking about corporate reputation means focusing on the company's behaviour towards stakeholders. Four stakeholder groups participate in the process of building corporate reputation, namely employees, investors, customers and the community in which the company (organization) operates. According to A. Adamus-Matuszyńska, the value developed by all stakeholder groups creates corporate reputation. The opinion (assessment) refers primarily to the intangible and subjective assets of the company. For each stakeholder group, the company presents subjective value and generates measurable benefits. Company value perceived by employees does not necessarily coincide with the assessment by investors, customers or owners.

The main assumption is that, in the reputation management process, it is necessary to identify stakeholder groups and understand their needs. In view of the conflicts of stakeholders' expectations, effective corporate reputation management, as well as family business reputation management, requires the identification and prioritization of key stakeholder groups and the identification of the expectations and values that are important to individual groups.

\section{Communication and Development of Dialogue with Stakeholders}

Dialogue with stakeholders is a long-term process and requires the company to be ready to change and to prepare well internally before inviting them to engage in dialogue. It also brings many benefits, including a better understanding of the business environment, building trust and reducing the risk of potential crises, for example, brought about by negative opinions. In order to be effective, key stakeholder groups should be identified by determining their impact and their importance to the company. This new business philosophy of the company's functioning has been fully justified in a significant number of research papers, among them by Bowen (1953), McGuire (1963), Carroll (1979), Wartick and Cochran (1985), Clarkson (1995), Drucker (1999), F. Reyes (Kietliński, Reyes, Oleksyn, 2005) and Bazzichi (2003). Their research findings show that this activity leads to building a strategy of competitive advantage based on the delivery of sustainable value for both shareholders and stakeholders. This means the permanent 
Table 3.1 Expectations and values of stakeholders

\begin{tabular}{|c|c|c|}
\hline Stakeholder & Expectations & Value \\
\hline $\begin{array}{l}\text { Shareholders } \\
\text { and owners }\end{array}$ & $\begin{array}{l}\text { - growth in company value } \\
\text { - } \text { maximizing the value of } \\
\text { shares } \\
\text { reliable and comprehen- } \\
\text { sive information } \\
\text { - compliance with stan- } \\
\text { dards and regulations } \\
\text { - competent management } \\
\text { bodies } \\
\text { - } \\
\text { positive image }\end{array}$ & $\begin{array}{l}\text { - } \quad \text { return on investment } \\
\text { maximizing company } \\
\text { - } \quad \text { value } \\
\text { - } \quad \text { good company image }\end{array}$ \\
\hline Employees & $\begin{array}{l}\text { - } \quad \text { satisfactory remuneration } \\
\text { - } \quad \text { rowarilment of obligations } \\
\text { reliable and comprehen- } \\
\text { sive information } \\
\text { - } \quad \text { the possibility of devel- } \\
\text { opment } \\
\text { - job satisfaction } \\
\text { - } \quad \text { safe working conditions } \\
\text { effective company man- } \\
\text { agement }\end{array}$ & $\begin{array}{l}\text { - } \quad \text { salaries } \\
\text { - } \quad \text { fringe benefits } \\
\text { - } \quad \text { upgrading qualifica- } \\
\text { - } \quad \text { tions } \\
\text { - } \quad \text { gork-life balance } \\
\text { good company image }\end{array}$ \\
\hline $\begin{array}{l}\text { Co-operators, } \\
\text { suppliers }\end{array}$ & $\begin{array}{l}\text { - financial credibility of the } \\
\text { partner } \\
\text { - } \text { compliance with commit- } \\
\text { - econts } \\
\text { - ethics of action } \\
\text { - culture and profession- } \\
\text { - } \text { alism of action } \\
\text { - } \text { quality of communication }\end{array}$ & $\begin{array}{l}\text { - } \quad \text { sales income } \\
\text { - } \quad \text { cooperation and } \\
\text { loyalty } \\
\text { - } \text { organizational devel- } \\
\text { opment } \\
\text { - quality of cooperation } \\
\text { innovation }\end{array}$ \\
\hline Customers & $\begin{array}{l}\text { - features, quality and func- } \\
\text { tionality of the product } \\
\text { - clear and accessible in- } \\
\text { formation } \\
\text { - } \text { attractive product design } \\
\text { - professional purchasing } \\
\text { and customer service } \\
\text { process } \\
\text { - personification of cus- } \\
\text { tomer relationships } \\
\text { - positive image of the } \\
\text { company } \\
\text { product safety }\end{array}$ & $\begin{array}{l}\text { - usefulness of purchased } \\
\text { products and services } \\
\text { - good company image, } \\
\text { brands } \\
\text { - innovation } \\
\text { - improving the quality } \\
\text { of life and well-being }\end{array}$ \\
\hline Competitors & $\begin{array}{l}\text { - fair competition } \\
\text { - } \quad \text { transparency and clarity } \\
\text { of competition activities }\end{array}$ & $\begin{array}{l}\text { - absence of losses due to } \\
\text { unfair competition }\end{array}$ \\
\hline
\end{tabular}


Table 3.1 (Continued)

\begin{tabular}{|c|c|c|}
\hline Stakebolder & Expectations & Value \\
\hline & $\begin{array}{l}\text { - culture and ethics of } \\
\text { business activities }\end{array}$ & $\begin{array}{l}\text { - } \text { no costs of protection } \\
\text { against unfair prac- } \\
\text { tices } \\
\text { an entrepreneurial } \\
\text { environment } \\
\text { enhancing the well- } \\
\text { being of society and } \\
\text { increasing its pur- } \\
\text { chasing power }\end{array}$ \\
\hline $\begin{array}{l}\text { Financial } \\
\text { institutions }\end{array}$ & $\begin{array}{l}\text { - } \quad \text { return on capital lending } \\
\text { - } \text { reliable financial perfor- } \\
\text { mance } \\
\text { - } \quad \text { tulfilment of liabilities } \\
\text { transparency, reliability } \\
\text { and comprehensiveness of } \\
\text { information } \\
\text { competent management } \\
\text { bodies }\end{array}$ & $\begin{array}{l}\text { - revenue arising from } \\
\text { lending capital } \\
\text { enhancing the well- } \\
\text { being of the popula- } \\
\text { tion and increasing its } \\
\text { creditworthiness }\end{array}$ \\
\hline $\begin{array}{l}\text { Government and } \\
\text { social } \\
\text { institutions }\end{array}$ & $\begin{array}{l}\text { - compliance with legal stan- } \\
\text { dards } \\
\text { - contributions to special- } \\
\text { purpose funds } \\
\text { supporting social and } \\
\text { charitable activities } \\
\text { cooperation to stimulate } \\
\text { local and national devel- } \\
\text { opment }\end{array}$ & $\begin{array}{l}\text { - revenue from taxes and } \\
\text { other forms of company } \\
\text { involvement } \\
\text { - } \text { new jobs } \\
\text { eliminating social dis- } \\
\text { parities by enhancing } \\
\text { the well-being of } \\
\text { society } \\
\text { protection of the } \\
\text { environment }\end{array}$ \\
\hline $\begin{array}{l}\text { Local, national, } \\
\text { and regional } \\
\text { communities }\end{array}$ & 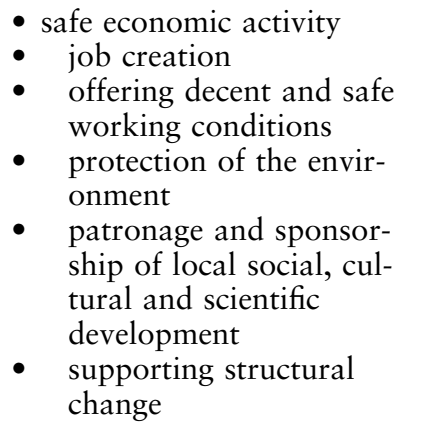 & $\begin{array}{l}\text { - revenue from taxes and } \\
\text { other forms of company } \\
\text { involvement } \\
\text { - creation of new jobs } \\
\text { - development of the } \\
\text { region } \\
\text { improving the quality } \\
\text { of life } \\
\text { protection of the } \\
\text { environment }\end{array}$ \\
\hline
\end{tabular}

Source: own study based on Paliwoda-Matiolańska (2009); Adamczyk (2009); Ciepiela (2014); Majchrzak (2009); Engelhardt (2009).

cooperation of the company with its stakeholders, creating suitable mechanisms for communicating with them (Trocki, Grucza, 2005; Olesiński, 2010). The most mature approach to stakeholder relationships involves systematic dialogue and joint planning and the 
implementation of various types of corporate social responsibility ventures. The most transparent and ethical behaviour is contained in the IS0 26000 standard, which obliges all entities to:

- shape sustainable development, health and social well-being;

- take stakeholders' expectations into account;

- behave and act in accordance with applicable national law and international standards;

- disseminate good CRS practices, both within the company and in its relationships with the environment (Paliwoda-Matiolańska, 2009; Hamrol, 2016).

The international standards of the AA1000 series are also a significant support for companies under CRS initiatives. They are as follows:

- AA 1000 Accountability Principles Standard (AA1000APS) defines three basic principles related to stakeholder relationship management: the principle of inclusivity, materiality and responsiveness,

- AA 1000 Stakeholder Engagement Standard (AA1000SES) shows what the process of stakeholder engagement should look like,

- AA 1000 Assurance Standard (AA1000AS) defines how to conduct the verification that ensures the reliability of the activities which a company conducts and the credibility of the social report (Wachowiak, 2011).

The standards point to the right of stakeholders to submit their views to the company authorities on the core tasks it performs and the need to establish rules for communication with stakeholders in order to ensure their engagement in the management process and to respond to the problems reported. The starting point of determining how to conduct dialogue with stakeholders is to recognize the principle of inclusivity as the basis for action, which is understood as recognition of stakeholders' participation in the development and implementation of a company's development strategy, which takes place in a sustainable and socially responsible manner. It also means recognizing that the company is accountable for the results of its activities to stakeholders and enables them to take an active part in finding solutions to these problems (Ćwik, 2010; Few, 2006; Herbuś, 2013).

Public relations and marketing practitioners pay attention to the importance of comprehensive and anticipatory activities in family business communication. This requires extensive mechanisms of cooperation with journalists, proactivity in media relationships, and the continuous monitoring of one's image and investment in a wide range of public relations tools. An assertive response is also crucial. Companies show helplessness towards, for example, negative blog posts and other manifestations of organized customer anger and are prone to defensive 


\section{Family Business Reputation Management}

behaviour. An analysis of the various communication crises of family businesses shows that, in most cases, there was a lack of information on the part of the company, but it also lacked assertiveness - the willingness to explain the company's position and maintain such a stance (if it did not concern obvious errors or abuses). The experience of companies that have to behave cautiously (sensitive industries) indicates that honesty is the best policy. The emergence of small but influential groups of recipients has changed the communication landscape, including reputation management.

The assumption of a family business as to what reputation truly means leads to consequences for communication and dialogue with stakeholders. The concept of corporate reputation is presented and interpreted in different ways in literature (see Chapter 1). There are different dimensions of reputation and their implications for management (Szwajca, 2018):

- Reputation of competence:

- Assessed professionalism - need to build competitive advantage,

- The importance of trust in competence - maintaining or improving the level of competence and service,

- The need to reconcile conflicting expectations of stakeholders the need to prioritize stakeholders,

- Rational basis for assessment - compliance with quality standards and contract terms,

- Reputation of character:

- Assessed prestige and recognition in the environment - the need to build a positive, strong image,

- The importance of honesty and ethics - observance of legal, ethical, promoted and expressed values,

- The need to take into account the various cultural norms of stakeholders - based on sustainable values that build corporate identity,

- Emotional foundation of assessment - building close human relationships with stakeholders;

- Reputation of competence and character:

- Basis for the assessment: comparing expectations with the company's actual activities - the need for compliance of words with actions in every aspect of activity.

Different understandings of reputation ("awareness", "asset", "assessment") will determine various communication actions, as their purpose will vary. It was assumed that for a family business, the concept of corporate reputation could mean: 
- a feature/features which signal the company's behaviour positively perceived by stakeholders,

- a barrier to market entry,

- a source of competitive advantage,

- intangible assets,

- the form of the market value of the company, the amount of which may be subject to changes over time, depending on the assessment of the company's activities,

- the way in which the company is perceived and assessed by stakeholders, which can attract loyal customers,

- a result of corporate identity,

- the essence/crystallization of what a company is, how it functions and how it communicates with its stakeholders.

In the context of defining the reputation and the related objectives of the company, it is also important to identify factors affecting the reputation of the family business by strengthening it. The following are core areas of strengthening the reputation of a family business:

- relationships between owners, positive relationships or conflicts occurring;

- relationships between employees and owners which affect the atmosphere at work;

- the quality of products or services offered;

- the quality of customer service, including an appropriate response to emerging errors;

- the uniqueness of products and services offered, and the difficulty of copying them by competitors;

- customer trust and loyalty;

- employee trust and loyalty;

- transparency and consistency of action;

- a business strategy understood by stakeholders;

- values characteristic of the family business.

\subsubsection{Reputation-building Strategy}

A strategy is a program to identify the company's core objectives in a specific functional area and how they can be achieved. In management sciences, the strategy is understood as a multidimensional category, which is necessary to ensure the proper functioning and sustainable development of a company in the market. A core component of the strategy appears to be the objective of achieving a lasting competitive advantage. The strategy is a process of defining the long-term objectives and objectives of the organization, as well as adopting directions of action and distributing the resources needed to achieve these objectives. 


\section{Family Business Reputation Management}

The identification of priorities in the strategy allows for the identification of operational actions to enable decision-making in an increasingly turbulent environment (Marjański, 2016). The reputation-building strategy adopted in family businesses can take a more or less formalized form:

- the assumptions in this respect and the action program as a separate document;

- a strategy which has not been codified in a document, albeit functioning as one of the core principles in the company;

- this strategy is part of other strategic documents, customer service standards, anti-corruption policies, policy of transparency of behaviour, cooperation with business partners or other similar documents.

In terms of reputation-building strategies, it is important to identify both values that are conducive to building the reputation of family businesses and the threats and risks of reputation loss. Among the former, the following may be important in family businesses: respect, loyalty, entrepreneurship, experience, responsibility, a good atmosphere, reliability, good relationships between family members, stability, heritage and sustainability, profit, common objectives, trust, family reputation, honour of a company, integrity towards stakeholders, transparency in action, coherent image, education, knowledge, the welfare of an employee who is not a member of the owner's family and intuition.

On the other hand, a threat to the reputation of a family business can be anything that can affect the expectations of stakeholders. The following may be specified here:

- financial performance and value of long-term investments - concerning the expectations of investors, shareholders, and business partners;

- the quality of management and leadership - concerning the expectations of investors and employees;

- action in compliance with the law - concerning the requirements of legislative bodies, supervisory authorities and rating agencies;

- the quality of products and the level of customer service - concerning customers, business partners, and consumer organizations;

- working conditions and corporate culture - concerning the expectations of employees, trade unions, offices for the protection of workers' rights;

- social responsibility - concerning the expectations of local communities, NGOs, social and charitable organizations, etc.;

- communication and crisis management - concerning the expectations of customers, investors and media. 


\subsubsection{Reputation Measurement}

The organization of the concept of reputation by M. Barnett, J. Jermier and B. Lafferty, and its understanding as a company asset (Barnett, Jermier, Lafferty, 2006) led to its conceptualization by Walker (2010) and became the basis for the proposal of a three-dimensional model by Lange, Lee, Dai (2011). The theoretical organization of reputation has led to a broader perception thereof in economics and management sciences.

Research on investor behaviour by numerous authors, including $\mathrm{M}$. Fernández-Gámez et al. (Fernández-Gámez, Gli-Corral, GalánValdivieso, 2016); Blajer-Gołębiewska and Kos (2016); Smith, Smith, Wang (2010); Brammer, Brooks, Pavelin (2006); and Rose and Thomsen (2004), is increasingly paying attention to the role of corporate reputation. It implies the need to define universal methods of measuring reputation from the perspective of investors. Also emphasized by the authors of the so-called soft aspects of microeconomic theory of the firm (Creedon, 2011; De Marcellis-Warin, Teodoresco, 2012) and practitioners of economic life (Reputation Institute UK, 2012) is the fact that, despite the perception of reputation as an extremely valuable asset, there is a problem with measuring it. C. Fombrun was the first to attempt to resolve the problem by introducing the concept of reputation capital into literature, while presenting a formula for its definition, which is the difference between company market value and the liquidation value of tangible assets (Fombrun, 1996; Caputa, 2015).

Improvements in the way corporate reputation is described and measured were addressed by, inter alia, Fombrun and Van Riel (1997), Schwaiger (2004), and Helm (2005). Their discussion referred to the company's non-financial factors and was based mainly on the HarrisFombrun Reputation Quotient (Fombrun, Gardberg, Sever, 2000) and the Fortune AMAC2 ranking (Pęksyk, 2014). According to M. Pęksyk, the former is based on 20 attributes collected in six areas covering:

- emotional appeal;

- product and service offer;

- vision and leadership in the sector;

- perception of the company by employees - working conditions;

- financial performance - based on key performance indicators;

- social responsibility (Pęksyk, 2014; Stelmaszczyk, Karpacz, 2016).

An estimate of financial reputation, taking the Harris-Fombrun Reputation Quotient ${ }^{\circledR}$ into account, was also presented by Bowd and Bowd (2002), who did not find a wider practical application. Subsequent research which took their results and experience from the economic and financial crisis of the 21 st century into account resulted in the methods of 


\section{Family Business Reputation Management}

the calculation of the reputation value of public enterprises being in line with the simplified identification of goodwill (Creedon, 2011; De Marcellis-Warin, Teodoresco, 2012).

Defining goodwill is challenging. However, there is a consensus among economists that goodwill may consist of tangible and intangible components such as its name, capital, fixed and current assets, financial resources or all kinds of rights, as well as any factors that enhance its value, for example, the way a company is organized, the structure of production, the human factor, their qualifications and their use and reputation.

Many of the above components of goodwill are intangible and are therefore more difficult to assess. But sometimes even the most tangible parts of the company's assets, such as land or real estate, can cause problems to valuers. This necessitates specific assumptions and a fixed value-determination procedure and requires the application of an appropriate valuation method.

According to the definition of valuation in the literature, company valuation is determined as a result of the chosen procedure - the valuation method and the price is the amount actually paid for the company or part of it.

Company valuation is a very complex process that results not only from its specificity, but also from the selection of its valuation method, taking reputation measurement into account. Such a compilation is presented in Figure 3.2.

Assuming that the company has a good reputation, a positive difference can be expected between its value determined by means of revenuebased methods and the value determined by means of asset-based methods. Mixed company valuation models assume that part of this difference is the value of corporate reputation; therefore, these methods are also referred to as reputation-based methods.

As the value of the company's intellectual capital disseminates, as the difference between market value and asset value, the concept of intellectual capital valuation emerged, equivalent to the difference between the book value and the market value of the company (market-to-book-ratio).

In the case of corporate activity, the value of intellectual capital has been reduced to the formula of Market Value Added (MVA), referred to as goodwill. With regard to the company, there are two valuable forms of intellectual capital - goodwill:

- accounting goodwill - equivalent to the mathematical difference between the market (revenue) and asset (book) value of a company, which gives the true value on a specified valuation date and in this context constitutes the present value;

- economic goodwill - equivalent to only part of the mathematical difference between the market (revenue) and the asset (book) value of 

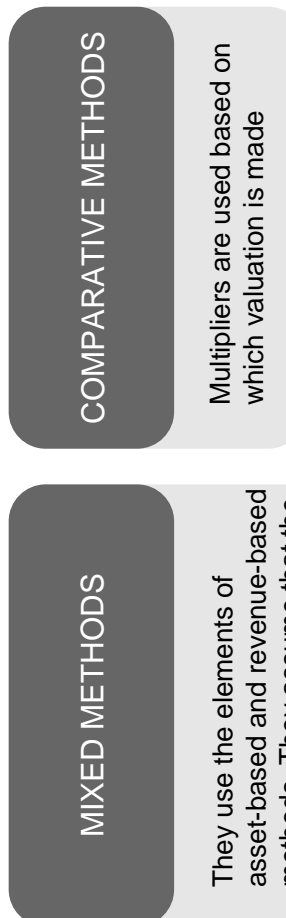

ఫญ ธ

(

웅 웡

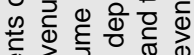

ญ ญ है ब ๑ 잉 () क्ष 为 入
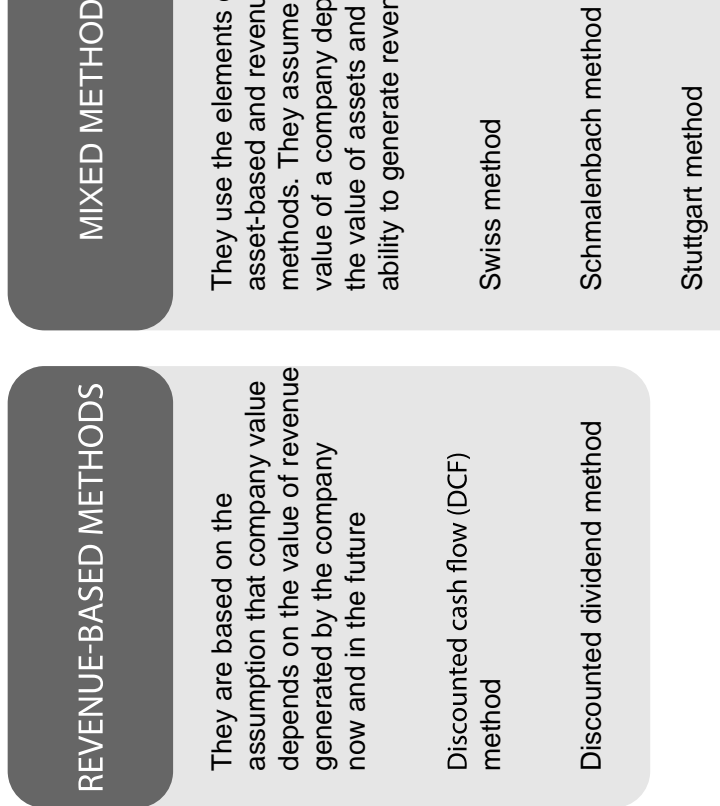

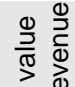

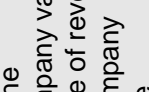

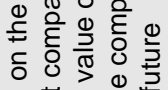

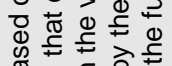

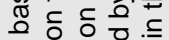

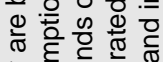

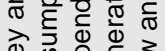
む)

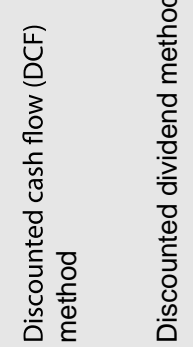

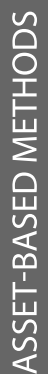
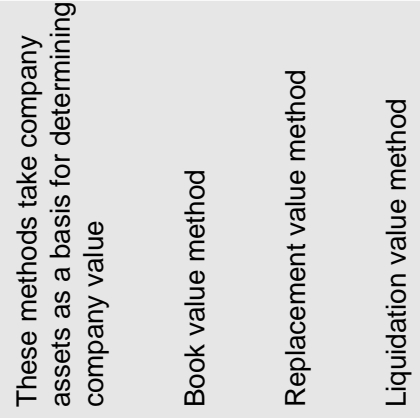

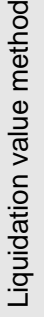

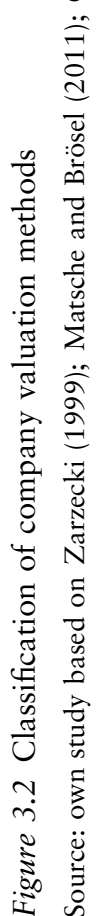




\section{Family Business Reputation Management}

the company on the date of valuation, which results from the so-called economic depreciation of goodwill over time, i.e. the need to invest in its reconstruction. These outlays - as real cash expenditure - reduce the value of goodwill over time (Hilt, Freeman, Harrison, 2001).

The concepts of valuation of the loss of economic goodwill over time have become a point which diversifies the mixed methods of company valuation.

To sum up the discussion on reputation measurement criteria, $\mathrm{K}$. Wójcik pays attention to the existence of reputation capital that develops over the years, i.e. it is relatively permanent (Wójcik, 2014). In his opinion, measurement criteria include two groups: those related to the organizational attributes and emotional indicators. The first group includes financial and economic stability, return on investment, quality of management, vision and development prospects, innovation, the attractiveness of the company as an employer and the ability to retain outstanding professionals. The group of emotional indicators includes ethics and reliability in behavioural terms, credibility, environment orientation, sensitivity to community expectations, recognizability, a good attitude towards competitors, social dimension of activity, affection, a feeling of satisfaction in the context of the environment, loyalty to the organization and exposure in the media.

The title of the chapter arbitrarily indicates the possibility of reputation management, and its content contains a hypothetical assumption that such a possibility exists. So has the business function in charge of this area emerged?

The ambiguity and multidimensionality of the phenomenon of reputation provokes the question of whether it is possible to manage this difficult category. Its level is shaped by a highly dispersed environment; building a reputation is a long-term process involving not only the owners/founders of family businesses, managers and employees, but also other groups of external stakeholders. This process is based on transparent, ethical and sustainable relationships with all stakeholders. These relationships are intended to contribute to the state of "becoming more liked or less hated". The goal of achieving these states is based on the core management function of planning. The plan for permanently improving a company's reputation is based on the principles necessary to earn respect, such as distinction, concentration, consistency, identity, transparency and the filtering of signals.

The benefits of corporate reputation should not obscure the effects of losing it. Threats to corporate reputation may be the owner's tendency to make decisions and micromanage, succession, conflicts with different backgrounds, strongly exposed emotions in family relationships, etc. The result of a loss of reputation, the effect of which can be enhanced by digital communication technologies and social media, is decreased sales, 
fewer customers, a fall in share prices, a reduction in access to capital, difficulties in recruiting valuable employees and others. Given the benefits of having a good reputation and taking the risk of losing it into account, shaping and maintaining this resource appears to be a core area of strategic action for family businesses.

The reputation management process can be included in logically successive stages or based on key resources, among which intangible resources are primarily important. The author's original concept of reputation management includes three important components: relationships, practices, and the organization of activities. With value as the basis for the concept, a logical sequence of processes which define the situation of the company was proposed. This concept required a step-by-step approach which identifies values, stakeholders, relationships resulting from the interaction between the company and the environment, and the strategies adopted by companies to build and measure reputation.

For the purposes of the work, it was assumed that measurable value could be attributed to corporate reputation. It is referred to as part of the surplus market value that can be attributed to the perception of a company as a responsible national and global organizational citizen. According to various sources, it is estimated that reputation can account for between $20 \%$ and $90 \%$ of the market value of the family business. Since the subject of the work was not to apply individual methods of reputation valuation but merely the awareness of the possibility of its valuation, the value of the reputation for individual companies was determined declaratively as a percentage of the value of the company concerned.

\section{References}

Adamczyk, J. (2009). Spoleczna odpowiedzialność przedsiębiorstw [Corporate social responsibility]. Warszawa: Polskie Wydawnictwo Ekonomiczne, pp. 87-96.

Antonucci, D. (2016). Risk maturity models: How to assess risk management effectiveness. London: Kogan Page, p. 72.

Aronoff, C. and Ward, J. (2016). Family business values: How to assure a legacy of continuity and success. Berlin: Springer.

Babbie E. (2003). Badania spoleczne $w$ praktyce [Social research in practice]. Warszawa: Wydawnictwo Naukowe PWN, p. 47.

Bańko, M., ed. (2005). Wielki stownik wyrazów obcych PWN [PWN great dictionary of foreign words]. Warszawa: Wydawnictwo Naukowe PWN, p. 1078.

Barnett, M.L., Jermier, J.M. and Lafferty, B. (2006). Corporate reputation: The definitional landscape. Corporate Reputation Review, 9(1), pp. 26-38.

Baron, R.A. and Tang, J. (2009). Entrepreneurs' social skills and new venture performance: Mediating mechanisms and cultural generality. Journal of Management, 35(2), pp. 282-306. 


\section{Family Business Reputation Management}

Baron, R.A., Markman, G.D. and Bollinger, M. (2006). Exporting social psychology: Effects of attractiveness on perception of entrepreneurs, their ideas for new products, and their financial success. Journal of Applied Social Psychology, 36(2), p. 475.

Bazzichi, O. (2003). Społeczna odpowiedzialność przedsiębiorstwa [Corporate social responsibility]. Społeczeństwo, 55/56(3/4), p. 499.

Blajer-Gołębiewska, A. (2017). Pomiar postrzeganej przez inwestorów reputacji przedsiębiorstwa [Measurement of corporate reputation as perceived by investors]. Studia i Prace WNEIZ US, 50(2), pp. 21-34.

Blajer-Gołębiewska, A. and Kos, M. (2016). Investors are more sensitive to information about financial rather than ethical reputation of a company: Evidence from an experimental study. Economics and Sociology, 9(1), pp. 11-31.

Blikle, A. (2015). Firmy rodzinne $w$ obliczu sukcesii [Family businesses in the face of succession]. [online]. Available at: http://www.moznainaczej.com.pl/ firmy-rodzinne-w-obliczu-sukcesji [Accessed 22 February 2019].

Bowd, R. and Bowd, L. (2002). Assessing a financial value for a corporate entity's reputation: A proposed formula. Manchester Metropolitan University Business School Working Paper Series, WP02/01, p. 8.

Bowen, H.R. (1953). Social responsibilities of the businessman. New York: Harper\&Row, p. 187.

Brammer, S, Brooks, C. and Pavelin, S. (2006). Corporate reputation and stock returns: Are good firms good for investors? ICMA Center Discussion Papers in Finance, 05, pp. 1-28.

Bukowska, U. (2006). Interesariusze a zarządzanie zasobami ludzkimi [Stakeholder and human resource management]. Zeszyty Naukowe Akademii Ekonomicznej w Krakowie, 711, p. 48.

Burke, R.J., Martin, G. and Cooper, C.L. (2011). Corporate reputation: Managing opportunities and threats. London: Gower Press, p. 4.

Business Destination Germany 2018. Foreign groups value Germany as a business location, KPMG. [online]. Available at: https:/hub.kpmg.de/businessdestination-germany-2018, p. 7. [Accessed 20 February 2020].

Caputa, W. (2015). Kapitat klienta $w$ budowaniu wartości przedsiębiorstwa [Customer capital in building the value of the enterprise]. Warszawa: CeDeWu, pp. 74-95.

Carroll, A.B. (1979). A three-dimensional conceptual model of corporate performance. Academy of Management Review, 4(4), pp. 497-505.

Carroll, C.E. (2013). The future of communication research in corporate reputation studies. In: C.E. Carroll, ed., The handbook of communication and corporate reputation, 1st ed. Oxford: Wiley-Blackwell, pp. 590-596.

Chełpa, S. (2004). Indukcja i dedukcja w zarządzaniu - problem teorii i praktyki [Induction and deduction in management - the issue of theory and practice]. In: H. Jagoda and J. Lichtarski, eds., Nowe kierunki $w$ zarzadzaniu przedsiębiorstwem - między teoria a praktyka [New trends in enterprise management - between theory and practice], 1st ed. Wrocław: Wydawnictwo Akademii Ekonomicznej im. O. Langego. 
Chełpa, S. (2004). Strategie badawcze kwalifikacji kierowniczych [Research strategies for managerial qualifications]. Zarzadzanie Zasobami Ludzkimi, 1, pp. 61-73.

Chun, R. (2005). Corporate reputation: Meaning and measurement. International Journal of Management Reviews, 7(2), pp. 91-109.

Ciepiela, M. (2014). Wpływ interesariuszy na zarządzanie przedsiębiorstwem [Impact of stakeholders on enterprise management]. Rynek - Społeczeństwo Kultura, 3(11), p. 25.

Clarkson, M.B.E. (1995). A stakeholder framework for analyzing and evaluating corporate social performance. Academy of Management Review, 20(1), pp. 92-117.

COSO. (2017). Enterprise risk management framework integrating strategy and performance. London: Kogan Page.

Creedon, B. (2011). Protecting your most valuable asset - reputation. Keeping Good Companies, May, pp. 213-217.

Ćwik, N. (2010). Nowy standard w stużbie interesariuszy - AA 1000 SES, edycja 2010. [online]. Available at: http://crnavigator.com/art_e18/nowy_standard_w_ sluzbie_interesariuszy_aa1000_ses_edycja_2010.html [Accessed 3 March 2019].

Ćwiklicki, M. (2010). Przesłanki stosowania teorii ugruntowanej w naukach o zarządzaniu [Prerequisites for the use of grounded theory in management sciences]. Acta Universitatis Lodziensis. Folia Oeconomica, 234, pp. 243-253.

Danielak, W. (2012). Ksztattowanie kapitatu relacyjnego $w$ matym i średnim przedsiębiorstwie [Development of relational capital in a small and mediumsized enterprise]. Wrocław: Wydawnictwo Uniwersytetu Ekonomicznego, p. 54.

Davies, G. and Miles, L. (1998). Reputation management: Theory versus practice. Corporate Reputation Review, 2(1), pp. 16-27.

Davies G., Chun, R., Da Silva, R.V. and Roper, S. (2003). Corporate Reputation and Competitiveness. London: Routledge, p. 99.

Dąbrowski, T.J. (2010). Reputacja jako źródło przewagi konkurencyjnej [Reputation as a source of competitive advantage]. In: B. Dobiegała-Korona and T. Doligaliski, eds., Zarzadzanie wartościa klienta. Pomiar i strategie [Customer value management. Measurement and strategies], 1st ed. Warszawa: Poltext, p. 75.

Dąbrowski, T. (2010). Reputacja przedsiębiorstwa: tworzenie kapitału zaufania [Corporate reputation: the creation of trust capital]. Kraków: Wolters Kluwer Polska, pp. 9-11.

Deutschlands beste Wirtschaftsprüfer. (2018). Available at: https://www.bestewirtschaftspruefer.de/.

De Marcellis-Warin, N. and Teodoresco, S. (2012). Corporate reputation: Is your most strategic asset at risk? CIRANO, April. Deutschlands Beste Wirtschaftsprüfer. Manager Magazin. Wirtschaft aus erster hand, April 2018, pp. 3-22.

Dowling, G.R. (2006). How good corporate reputations create corporate value. Corporate Reputation Review, 9(2), pp. 134-143.

Downar, W. and Niedzielski, P. (2006). Zarządzanie interesariuszami jako instrument wspomagający realizację projektów gospodarczych $\mathrm{w}$ transporcie [Stakeholder management as an instrument supporting the implementation of economic projects in transport]. In: E. Załoga, ed., Wspótczesne procesy $i$ 


\section{Family Business Reputation Management}

zjawiska $w$ transporcie [Modern processes and phenomena in transport], 1st ed. Szczecin: Wydawnictwo Naukowe Uniwersytetu Szczecińskiego, p. 162.

Drucker, P.F. (1999). Społeczeństwo pokapitalistyczne [Post-capitalist society]. Warszawa: Wydawnictwo Naukowe PWN, p. 87.

Dyduch, W. (2013). Ilościowe badanie i operacjonalizacja zjawisk w naukach o zarządzaniu [Quantitative research and operationalisation of phenomena in management sciences]. In: W. Czakon, ed., Podstawy metodologii badań $w$ naukach o zarzadzaniu [Basics of Research Methodology in Management Sciences], 2nd ed. Warszawa: Wolters Kluwer.

Eberl, M. and Schwaiger, M. (2005). Corporate reputation: Disentangling the effects on financial performance. European Journal of Marketing, 39(7/8), pp. 838-854.

Engelhardt, J., ed. (2009). Wspótczesne przedsiębiorstwo [Contemporary enterprise]. Warszawa: CeDeWu, p. 74.

Ferguson, T.D., Deephouse, D.L. and Ferguson, W.L. (2000). Do strategic groups differ in reputation? Strategic Management Journal, 21(12), pp. 1195-1214.

Fernández-Gámez, M.A., Gli-Corral, A.M. and Galán-Valdivieso, F. (2016). Corporate reputation and market value. Expert Systems with Applications, 46, pp. 69-76.

Few, S. (2006). Visual communication. Cognos Innovation Center for Performance Management, September 13, p. 3.

Figiel, A. (2011). Z czego wynikają błędy w zarządzaniu reputacją przedsiębiorstwa? [Sources of mistakes in corporate reputation management]. Przedsiębiorczość i Zarządzanie, 12(4), pp. 20-36.

Figiel, A. (2013). Reputacja $w$ zarzadzaniu przedsiębiorstwem [Reputation in enterprise management]. Kraków: Wydawnictwo Uniwersytetu Ekonomicznego, p. 17.

Fombrun, C.J. (1996). Reputation: Realizing value from the corporate image. Boston: Harvard Business School Press, p. 92.

Fombrun, C.J. and Foss, C.B. (2001). The reputation quotient. Part 1: Developing a reputation quotient. The Gauge: Newsletter of Worldwide Communications Research, 14(3).

Fombrun, C.J. and Rindova, V. (1998). Reputation management in global 1000 firms: A benchmarking study. Corporate Reputation Review, 1(3), pp. 205-212.

Fombrun, C.J. and Van Riel, C.B.M. (1997). The reputational landscape. Corporate Reputation Review, 1(1/2), pp. 5-13.

Fombrun, C.J. and Van Riel, C.B.M. (2004). Fame and fortune: How successful companies build winning reputations. Upper Saddle River: FT Press, p. 86.

Fombrun, C.J., Gardberg, N.A. and Sever, J.M. (2000). The reputation quotient SM: A multi-stakeholder measure of corporate reputation. The Journal of Brand Management, 7(4), pp. 241-255.

Freeman, R.E. (2010). Strategic management. A stakeholder approach. Cambridge: Cambridge University Press, p. 25.

Freeman, R.E. and Phillips, R.A. (1995). Efficiency, effectiveness, and ethics: A stakeholder view. In: W.W. Gasparski and L.V. Ryan, eds., Human action in 
business: Praxiological and ethical dimensions, 1st ed. New York: Routledge, pp. 65-81.

Glaser, B.G. and Strauss, A.L. (2009). Odkrywanie teorii ugruntowanej: strategie badania jakościowego [Discovery of grounded theory: Strategies for Qualitative Research]. Kraków: Nomos.

Grant, R.M. (1991). The resource-based theory of competitive advantage: Implications for strategy, formulation. California Management Review, 33(3), pp. 114-135

Gregorczyk, S. (2013). Globalizacja a zarządzanie ryzykiem strategicznym w przedsiębiorstwie [Globalization and strategic risk management in a company]. In: R. Bartkowiak and P. Wachwiak, eds., Wiedza i bogactwo narodów [Knowledge and wealth of nations] 1st ed. Warszawa: Szkoła Główna Handlowa - Oficyna Wydawnicza, p. 15.

Grudziński, M. (2011). Wybrane problemy związane z wyceną przedsiębiorstw w Polsce [Selected problems related to the valuation of companies in Poland]. Studia i Prace Wydziału Nauk Ekonomicznych i Zarzadzania, 24, pp. 39-49.

Hamrol, A. (2016). Strategie i praktyki sprawnego dziatania: lean, six sigma $i$ inne [Strategies and practices for efficient action: Lean, six sigma and others]. Warszawa: Wydawnictwo Naukowe PWN, pp. 115-118.

Hąbek, P. (2009). Społeczna odpowiedzialność przedsiębiorstw, jako koncepcja firmy zorientowanej na interesariuszy [Corporate social responsibility as the concept of a stakeholder-oriented company]. Organizacja i Zarzadzanie, 2(6), pp. 69-86.

Helm, S. (2005). Designing a formative measure for corporate reputation. Corporate Reputation Review, 8(2), pp. 95-109.

Herbuś, A. (2013). Teoria interesariuszy w kontekście standardu AA 1000 [The theory of stakeholders in the context of AA 1000 standard]. [online]. Available at: http://www.energiaisrodowisko.pl/spoleczna-odpowie-dzialnosc-biznesu. [Accessed 20 February 2020].

Hilt, M.A., Freeman, R.E. and Harrison, J.S. (2001). The Blackwell Handbook of Strategic Management. Oxford: Blackwell Business, p. 300.

Honey, G. (2009). A short guide to reputation risk. London: Routledge, pp. 2-8.

Jabłoński, A. (2013). Modele zrównoważonego biznesu w budowie dtugoterminowej wartości przedsiębiorstw z uwzględnieniem ich społecznej odpowiedzialności [Sustainable business models in building the long-term value of enterprises taking their social responsibility into account]. Warszawa: Difin, p. 77.

Jabłoński, A. (2015). Skalowalność modeli biznesu w środowisku sieciowym [Scalability of business models in the network environment]. Warszawa: Difin, p. 137.

Jackson, B.B. (1985). Winning and keeping industrial customers: The dynamics of customer relations. Lexington: D.C. Heath and Company, p. 125.

Kaczmarczyk, S. (2003). Badania marketingowe: Metody i techniki [Marketing research: Methods and techniques]. Warszawa: Polskie Wydawnictwo Ekonomiczne, p. 180.

Kietliński, K., Reyes, V.M. and Oleksyn, T. (2005). Etyka w biznesie i zarzadzaniu [Ethics in business and management]. Kraków: Oficyna Ekonomiczna, p. 132. 


\section{Family Business Reputation Management}

Klimek, J. and Żelazko, B. (2014). Zarządzanie reputacją firmy rodzinnej [Management of the reputation of a family business]. In: J. Klimek and B. Żelazko, eds., Zarzadzanie firma rodzinna - wybrane zagadnienia [Family business management - selected issues], 1st ed. Warszawa: Oficyna Wydawnicza Szkoła Główna Handlowa, p. 13.

Konecki, K. (2000). Studia z metodologii badań jakościowych [Studies in quality research methodology]. Warszawa: Wydawnictwo Naukowe PWN.

Kończak, J., Bylicki, P. and Borkowska, K. (2016). Rola komunikacji korporacyjnej [Role of corporate communication]. Warszawa: Public Dialog, pp. 27-30.

Kozielski, R. (2017). Understanding the New Business Paradigm in Eastern Europe. Bingley: Emerald Publishing Limited, p. 136.

Kubiak, K., ed. (2012). Zarzadzanie $w$ sytuacjach kryzysowych niepewności [Crisis management of uncertainties]. Warszawa: Wyższa Szkoła Promocji, p. 10.

Lange, D., Lee, P., Dai, Y. (2011). Organizational reputation: A review. Journal of Management, 37(1), pp. 153-184.

Lisiński, M. (2016). Metody naukowe w metodologii nauk o zarządzaniu [Scientific methods in the methodology of management science]. Przeglad Organizacji, 4, p. 13.

Lisiński, M. (2016). Procedury naukowe indukcji zupełnej i niezupełnej w metodologii nauk o zarządzaniu [Scientific procedures for complete and incomplete induction in the methodology of management sciences]. Zeszyty Nankowe Uniwersytetu Ekonomicznego w Krakowie, 6 (954), pp. 23-46.

Lovett, M., Peres, R. and Shachar, R. (2013). On brands and Word-of-Mouth. Journal of Marketing Research, 50(4), pp. 427-444.

Maciejewski, G. (2010). Ryzyko w decyzjach nabywczych konsumentów [Risk in consumer purchasing decisions]. Katowice: Wydawnictwo Uniwersytetu Ekonomicznego.

Mahon J.F. (2002). Corporate reputation. Research agenda using strategy and stakeholder literature. Business Society, 41(4), pp. 415-445.

Majchrzak, K. (2009). Zarządzanie reputacją we współczesnym przedsiębiorstwie [Reputation management in a modern enterprise]. In: M. Matejun, M. Szczepańczyk, eds., Współczesne metody zarzadzania w praktyce gospodarczej [Modern management methods in economic practice], 1st ed. Łódź: Wydawnictwo Politechniki Łódzkiej, pp. 212-222.

Majchrzak, K. (2015). Zasady skutecznego zarządzania reputacją przedsiębiorstwa [Principles of effective management of corporate reputation]. Prestiż - Relacje Gospodarcze. [online]. Available at: http://prestiz.info.pl/ Zasady\%20skutecznego\%20zarz\%C4\%85dzania\%20\%20reputacj\%C4 $\% 85 \% 20$ przedsi\%C4\%99biorstwa,341,3328 [Accessed 07 March 2019].

Makowicz, B. (2011). Compliance $w$ przedsiębiorstwie [Compliance in the enterprise]. Warszawa: Wolters Kluwer Polska, pp. 69-73.

Marjański, A. (2012). Specyfika firm rodzinnych [Specificity of family businesses]. In: Firma $w$ rodzinie czy rodzina $w$ firmie. Metodologia wsparcia firm rodzinnych [Business in the family or the family in business. Methodology of support for family businesses], 1st ed. Warszawa: Polska Agencja Rozwoju Przedsiębiorczości, pp. 30-38. 
Marjański, A. (2016). Strategie małych firm rodzinnych - specyfika i uwarunkowania [Strategies of small family businesses - specificity and conditions]. In: J. Klimek and B. Żelazko, eds., Zarzadzanie firma rodzinna - wybrane zagadnienia [Family business management - selected issues], 1st ed. Warszawa: Oficyna Wydawnicza Szkoła Główna Handlowa, pp. 67-68.

Matsche, M.J. and Brösel, G. (2011). Wycena przedsiębiorstwa. Funkcje, metody, zasady [Company valuation. Functions, methods, rules]. Warszawa: Wolters Kluwer Polska, pp. 3-16.

McGuire, J.W. (1963). Business and society. New York: McGraw-Hill, p. 144.

Miller, D., Le Breton-Miller, I. and Scholnick, B. (2008). Stewardship vs. stagnation: An empirical comparison of small family and non-family businesses. Journal of Management Studies, 45(1), pp. 51-78.

Nagel, E. (1970). Struktura Nauki [Structure of science]. Warszawa: Państwowe Wydawnictwo Naukowe, pp. 122-141.

Olesiński, Z. (2010). Zarządzanie relacjami międzyorganizacyjnymi [Management of interorganizational relationships]. Warszawa: Wydawnictwo C.H. Beck, p. 63.

Paliszkiewicz, J. (2013). Zaufanie $w$ zarzadzaniu [Trust in management]. Warszawa: Wydawnictwo Naukowe PWN, p. 163.

Paliwoda-Matiolańska, A. (2009). Odpowiedzialność społeczna w procesie zarzadzania przedsiębiorstwem [Social responsibility in the enterprise management process]. Warszawa: Wydawnictwo C.H. Beck, pp. 59, 109.

Penc-Pietrzak, I. (2016). Zmiany paradygmatów w zarządzaniu [Changes of paradigms in management]. Zeszyty Naukowe. Organizacja $i$ Zarzadzanie, 65(1209), pp. 93-106.

Pęksyk, M. (2014). W poszukiwaniu wartości reputacji [In Search of Reputation Value]. Zeszyty Naukowe Uniwersytetu Szczecinskiego, (804)67, pp. 519-528.

Podolny, J.M. and Phillips, D.J. (1996). The dynamics of organizational status. Industrial and Corporate Change, 5(2), pp. 453-471.

Powers, T.L. and Reagan, W.R. (2007). Factors influencing successful buyerseller relationship. Journal of Business Research, 60(2), p. 1235.

Prahalad C.K. and Krishnan, M.S. (2010). Nowa era innowacji [The New Age of Innovation]. Warszawa: Wydawnictwo Naukowe PWN, p. 40.

Przywecki, M., Słabosz, J. and Ziomko, R. (2013). Zarzadzanie ryzykiem $i$ ubezpieczeniami w firmach $w$ Polsce. Raport AON Polska [Risk and insurance management in companies in Poland. AON Poland report]. Warszawa: AON Risk Services.

Reputation Institute UK. (2012). Corporate Reputation: The Main Driver of Business Value. White Paper, May. [online]. Available at: http:// reputationhouse.co.za.dedi353.nur4.host-h.net/wp-content/uploads/2015/ 02/2012_UK_CRO_Whitepaper.pdf [Accessed 07 March 2019]

Roberts, P.W. and Dowling, G.R. (2002). Corporate reputation and sustained superior financial returns. Strategic Management Journal, 23(12), pp. 1077-1093.

Rodriguez, M.A. and Ricart, J.E. (2002). Towards the sustainable business. Revista de Antiguos Alumnos del IESE, 85, p. 30-31. 


\section{Family Business Reputation Management}

Rok, B. (2013). Podstawy odpowiedzialności społecznej w zarzadzaniu [Fundamentals of Social Responsibility in Management]. Warszawa: Wydawnictwo Poltext, pp. 93-94.

Rose, C. and Thomsen, S. (2004). The Impact of corporate reputation on performance. European Management Journal, 22(2), pp. 201-210.

Sandman, P. (2011). Two kinds of reputation management. Bezpieczeństwo $i$ Technika Pożarnicza, 24(4), pp. 9-17.

Saunders, E.J., ed. (2011). Przewodnik - jak monitorować systemy kontroli wewnętrznej [A guide to monitoring internal control systems]. Warszawa: Polski Instytut Kontroli Wewnętrznej, p. 59.

Schreiber, E. (2002). Why do many otherwise smart CEO's mismanage the reputation asset of their company. Journal of Communication Management, 6(3), pp. 209-219.

Schwaiger, M. (2004). Components and parameters of corporate reputation - an empirical study. Schmalenbach Business Review, 56(1), p. 46-71.

Siemianowski, A. (1976). Poznawcze i praktyczne funkcje nauk empirycznych [Cognitive and practical functions of empirical sciences]. Warszawa: Państwowe Wydawnictwo Naukowe, p. 58-78

Smith, K.T., Smith, M. and Wang, K. (2010). Does corporate reputation translate into higher market value? Journal of Strategic Management, 18(3), pp. 201-221.

Stelmaszczyk, M. and Karpacz, J. (2016). Związek między dzieleniem się wiedzą a innowacjami mediowany zaufaniem - poziom indywidualny [Relationship between knowledge sharingand innovations mediated by trust at the individual level]. Prace Naukowe Uniwersytetu Ekonomicznego we Wrocławiu, 422, p. 95-105.

Sułkowski, Ł. (2004). Neopozytywistyczna mitologia w nauce o zarządzaniu [Neo-Positivist Mythology in Management Science]. Organizacja $i$ Kierowanie, 1(115), pp. 3-14.

Susniene, D. (2008). Synergy and strategic value of organization - stakeholder relationships. Economics and Management, 13, pp. 842-847.

Szarucki, M. (2016). Koncepcja doboru metod w rozwiazywaniu problemów zarzadzania [The concept of selecting methods in solving management problems]. Kraków: Wydawnictwo Uniwersytetu Ekonomicznego, p. 85.

Szumniak-Samolej, J. (2013). Odpowiedzialny biznes $w$ gospodarce sieciowej [Responsible business in the network economy]. Warszawa: Wydawnictwo Poltext, pp. 27-28.

Szwajca, D. (2016). Zarzadzanie reputacja przedsiębiorstwa: budowa i odbudowa zaufania interesariuszy [Corporate reputation management: Building and rebuilding the trust of stakeholders]. Warszawa: CeDeWu, pp. 46, 47.

Szwajca, D. (2018). Wielowymiarowy charakter reputacji przedsiębiorstwa implikacje dla zarządzania [The multidimensional character of corporate reputation - implications for management]. Studia Ekonomiczne, 351, p. 159.

Szwajca, D. and Gąsiorek, M. (2015). Kultura organizacyjna jako fundament budowania reputacji przedsiębiorstwa [Organizational culture as the foundation for building corporate reputation] In: K. Ciuła-Urbanek, M. Jabłoński, B. Koperski and B. Piotrowski, eds., Człowiek i relacyjność: ujęcie 
socjologiczno-filozoficzne [Man and relationality: A sociological-philosophical approach], 1st ed. Krosno: Novum, p. 193.

Trocki, M. and Grucza, B. (2005). Analiza interesariuszy [Stakeholder analysis]. Warszawa: Bizarre, p. 23.

Urbanowska-Sojkin, E. (2013). Ryzyko w wyborach strategicznych w przedsiębiorstwach [Risks in strategic choices in companies]. Warszawa: Polskie Wydawnictwo Ekonomiczne, p. 56.

Wachowiak, P. (2011). Społeczna odpowiedzialność biznesu - wyzwania stojące przed polskimi przedsiębiorstwami [Corporate social responsibility challenges facing Polish companies.]. E-Mentor, 4 (41), pp. 22-28.

Walker, K. (2010). A Systematic review of the corporate reputation literature: Definition, measurement, and theory. Corporate Reputation Review, 12(4), pp. 357-387.

Wartick, S.L. (1992). The relationship between intense media exposure and change in corporate reputation. Business and Society, 31(1), pp. 33-49.

Wartick, S.L. and Cochran, P.L. (1985). The evolution of the corporate social performance model. Academy of Management Review, 10(4), pp. 758-769.

Werr, A, Blomberg, J. and Löwstedt, J. (2009). Gaining external knowledge boundaries in managers' knowledge relations. Journal of Knowledge Management, 13(6), p. 451.

Wesołowski, W.J. (2007). Zasady prowadzenia badań w naukach o zarządzaniu [Research Principles in Management Sciences]. Ekonomika $i$ Organizacja Przedsiębiorstwa, 9, pp. 3-11.

Wit, B. (2016). Model biznesu z perspektywy interesariuszy [Business Model from the Perspective of Stakeholders]. Przedsiębiorstwo we wspótczesnej gospodarce - teoria i praktyka, 4, pp. 87-99.

Wood, E. and Somerville, I. (2016). Public relations and corporate identity. In: A. Theaker, ed., The public relations handbook, 5th ed. London: Routledge, pp. 144-171.

Wójcik, K. (2014). Wszystko, co chciałabym wiedzieć o public relations i nie boję się zapytać - dylematy PR [Everything I would like to know about public relations and am not afraid to ask - PR dilemmas]. Studia Ekonomiczne, 185, pp. 17-36.

Zarzecki, D. (1999). Metody wyceny przedsiębiorstw [Business valuation methods]. Warszawa: Fundacja Rozwoju Rachunkowości w Polsce, p. 51.

Zieleniewski, J. (1969). Organizacja $i$ zarzadzanie [Organization and Management]. Warszawa: Państwowe Wydawnictwo Naukowe, p. 72

Zrałek, J. (2018). Konsument wobec wyzwań zrównoważonej konsumpcji: zrównoważone zachowania konsumenckie $i$ ich determinanty [Consumers and the challenges of sustainable consumption: sustainable consumer behavior and its determinants]. Katowice: Wydawnictwo Uniwersytetu Ekonomicznego, p. 127.

Zsidisin, G.A., Ragatz, G.L. and Melnyk, S.A. (2005). The dark side of supply chain management. Supply Chain Management Review, 9(2), pp. 46-52.

Żemigała, M. (2012). Controversies over corporate social responsibility. Human Resources Management \& Ergonomics, 6(1), pp. 118-128. 


\section{Family Business Reputation Management}

\subsection{Research Methodology}

When describing the concept of family business reputation management, not only were the course of research and the methods and techniques used indicated, but also the methodological assumptions they were based on. They are formed by induction, as a core method of scientific research and a method of the grounded theory.

As the basis for all research in the empirical part of the work, the marketing cycle of S. Kaczmarczyk, which was conducted according to the following sequence of activities, was adopted: 1) research design; 2) sample selection and construction of a measuring instrument; 3) collection of data; 4) checking and analysis of data; 5) interpretation, presentation and evaluation of results (Kaczmarczyk, 2003).

As a result of the research procedure, the following specific objective was adopted: the identification of core components of the concept of family business reputation management and the relationship between them.

The above-mentioned objective was specified by defining particular tasks which included:

1. Defining factors which determine the reputation of family businesses.

2. Indicating which areas of operation of a family business are affected by its reputation.

3. Indicating which stakeholders of a family business have a real impact on the functioning and performance of the company.

4. Determining what types of strategies family businesses use in building their reputation and relationships with key stakeholder groups.

5. Determining whether the reputation management strategy is longlasting in terms of the process of succession, or whether the perception of priorities in the process of reputation management changes with successive generations.

DOI: $10.4324 / 9781003226215-4$ 
6. Determining if family businesses undertake communication activities to build reputation, and if so, to what extent.

7. Determining what values the reputation of a family business is correlated with.

8. Defining the key factors and elements of the reputation management process in family businesses.

The above-mentioned specific tasks provided the basis for the determination of questions in the questionnaire.

All the activities described above constituted the first stage of the marketing cycle - research design. They resulted substantively from a specific objective and aimed to verify the hypotheses presented in the introduction. Together, they constituted a coherent whole, which imposed a further course of research.

The subsequent step of the adopted cycle is the selection of the sample and the construction of the measuring instrument. It was important to define the surveyed population to learn the opinions of the family businesses which were the subjects of research and identify the core elements of the concept of family business reputation management and their relationships.

The size of the research sample was 300 entities - family businesses. The respondents were representatives of family businesses (owners, coowners, successors or management/board representatives), who have knowledge of corporate reputation management and decide or co-decide on company policy. In answering the interview questions, they expressed their views on the areas examined. Although the survey provides less objective information than actual, observable and quantifiable figures, it is a widely recognized and applied method of studying phenomena in management sciences.

The research was conducted on a national scale. The sample included Polish enterprises which fulfilled the criteria of family businesses. Due to the lack of full selection range, the decision to use the prepared database of family businesses and draw from this base was made. Every second company from the prepared database with which an attempt to establish contact was made was drawn to participate in the survey. If the interview was not possible at a given company (e.g. because of refusal, the lack of a suitable person fulfilling the assumed recruitment criteria, difficulties in determining the date of the survey, or repeated failure to answer the phone) an attempt was made to establish a connection with another entity from the database, and then the draw procedure was repeated. The measurement was conducted until the assumed effective sample size $(\mathrm{N}=300)$ was achieved, taking into account the quotas assumed. In addition, in order to obtain a representation of family businesses which was as close as possible to the actual group of family businesses, units were drawn for the sample taking the specific characteristics of the surveyed 


\section{Family Business Reputation Management}

population into account, in proportion to the shares of these characteristics in the surveyed population (Kędzior, Karcz, 2007). Therefore, every effort was made to ensure that the structure of the sample studied best reflects the real structure of Polish family businesses. Such quotas were determined based on an analysis of the data in the available studies, containing information on the likely, approximate structure of Polish family businesses. Thus, the following quotas of family businesses were assumed by the number of employees: up to 10 people - about $15 \%$ (socalled micro-enterprises); from 10 to 49 people - about 50\% (small enterprises); from 50 to 249 people and 250 or more people - about $35 \%$ (medium-sized and large enterprises). The quotas were approximate because there are no complete and indisputable data on the structure of the collectivity of Polish family businesses or databases that could act as a selection range. In addition, in terms of the adopted research objectives, efforts were made to conduct as many interviews as possible with representatives of medium-sized and large enterprises with at least 20 years on the market, which are supposed to have a relatively well-developed reputation management policy. Sole traders and businesses without employees were excluded from the research. Table 4.1 shows the characteristics of the sample categorized by the core characteristics of the family businesses and their representatives.

The research was conducted in January and February 2019. It used different, mutually complementary research methods and techniques (of a quantitative and qualitative nature), in accordance with the principle of methodological triangulation. The research took place in two stages. In the first one, qualitative research was conducted to collect information from entrepreneurs representing family businesses (the individual indepth interview, or IDI, technique). The qualitative component was primarily exploratory research used to develop an optimal version of the tool for the main measurement in stage two. Such an approach made it possible to obtain as much knowledge as possible and, consequently, contributed to the formulation of the most accurate research conclusions and recommendations possible. The main research was quantitative and exploratory. It was conducted by means of computer-assisted telephone interview (CATI). In quantitative research, a standardized interview questionnaire was used, consisting of three substantive parts constituting a total of 14 questions and particulars.

The first part of the questionnaire contained questions to determine how respondents understand the concept of reputation, how they define the characteristics of reputation and what benefits a good reputation has for the company and its development. The second part of the tool contained questions to collect respondents' views on company stakeholders (who the key stakeholders that have a real impact on the operation and performance of the company are). The third part of the questionnaire also included questions on reputation-building strategies, and in the next 
Table 4.1 Core characteristics of the sample $(\mathrm{N}=300)$

\begin{tabular}{|c|c|c|}
\hline Specification & Number & $\%$ \\
\hline \multicolumn{3}{|l|}{ Family businesses } \\
\hline \multicolumn{3}{|l|}{ Number of employees } \\
\hline Fewer than 10 people & 39 & 13.0 \\
\hline Between 10 and 49 people & 150 & 50.0 \\
\hline Between 50 and 249 people & 102 & 34.0 \\
\hline 250 people or more & 9 & 3.0 \\
\hline \multicolumn{3}{|c|}{ Type of market on which the company operates (predominant market) } \\
\hline B2C market & 126 & 42.0 \\
\hline B2B market & 174 & 58.0 \\
\hline \multicolumn{3}{|l|}{ Core business profile (predominant profile) } \\
\hline Production & 94 & 31.3 \\
\hline Trade & 80 & 26.7 \\
\hline Service & 126 & 42.0 \\
\hline \multicolumn{3}{|l|}{ Ownership structure } \\
\hline $91 \%$ to $100 \%$ in the hands of the owner or his/her family & 272 & 92.0 \\
\hline $76 \%$ to $90 \%$ in the hands of the owner or his/her family & 16 & 5.3 \\
\hline $51 \%$ to $75 \%$ in the hands of the owner or his/her family & 8 & 2.7 \\
\hline \multicolumn{3}{|l|}{ Overall assessment of the company's economic situation } \\
\hline Very good & 10 & 3.3 \\
\hline Good & 220 & 73.3 \\
\hline Satisfactory & 64 & 21.3 \\
\hline Difficult & 4 & 1.3 \\
\hline Very difficult & 2 & 0.7 \\
\hline \multicolumn{3}{|l|}{ Year in which the company was established } \\
\hline 2011 and later & 48 & 16.0 \\
\hline $2000-2010$ & 99 & 33.0 \\
\hline 1989-1999 & 99 & 33.0 \\
\hline $1945-1988$ & 48 & 16.0 \\
\hline before 1945 & 6 & 2.0 \\
\hline \multicolumn{3}{|l|}{ Respondents } \\
\hline \multicolumn{3}{|l|}{ Position } \\
\hline Owner & 128 & 42.7 \\
\hline Successor & 104 & 34.7 \\
\hline Other (director/manager/president) & 68 & 22.7 \\
\hline
\end{tabular}

Source: own study.

one, those related to ways of communication between respondents and stakeholders.

The substantive questions were formulated in the form of closed, semiclosed or open-ended questions and questions in the form of measuring scales. The scales used were sequential, seven-point and unipolar. The substantive questions were strictly subordinated to the research objective. Particulars enabled the description of the research sample and allowed for the presentation of the results obtained in the research cross-sections.

The research was conducted by computer-assisted telephone interview (CATI). The specificity of this method of obtaining information means 


\section{Family Business Reputation Management}

that there are no obstacles to obtaining an adequate amount of data or the need for additional verification and analysis of data, which is inscribed in the information collection procedure. For this reason, two consecutive stages of the marketing cycle of S. Kaczmarczyk can be considered fulfilled according to the requirements adopted throughout the cycle.

The interpretation, presentation and evaluation of results is the subsequent stage of the marketing cycle, reduced to the presentation of two sets of information. The first describes the group of family businesses which participate in the research, while the second will focus on the statistical tools used in the IBM SPSS Statistics 24 software. These will be applied in detail to the assessment of the components of family business reputation management in the following parts of this chapter.

\section{A Picture of Family Businesses which Participated in the Research}

The majority of companies surveyed are family businesses $(92.0 \%)$, where all or almost all of the capital (between $91 \%$ and $100 \%$ ) belongs to the owner or members of his/her family. The sample included production $(31.3 \%)$ and trade companies $(26.7 \%)$. However, the largest percentage of respondents $(42.0 \%)$ were service companies. Most of the companies surveyed $(58.0 \%)$ operated on the B2B market, focusing their attention on the service of other companies and institutions. The sample included family businesses located in all 16 provinces.

According to the assumptions, the companies surveyed were represented by their owners $(42.7 \%)$ or successors $(34.7 \%)$, or other people responsible for reputation management at the company $(22.7 \%)$. These were both men $(54.0 \%)$ and women $(46.0 \%)$, usually with tertiary education $(62.0 \%)$. When assessing the economic situation of their company (based on the financial performance for the last two years), they usually declared that it was good $(73.3 \%)$ or satisfactory $(21.3 \%)-$ see Table 4.1.

\section{Statistical Tools for Data Analysis}

The analysis of the information obtained from the surveys was conducted by means of IBM SPSS Statistics 24 software. The following statistical tools were used in the research: correlation analysis, cluster analysis and factor analysis. Correlation analysis is aimed at detecting the relationship between the variables, assessing its direction and strength. The direction may be positive or negative, while the degree of the strength of the relationship is usually described as weak, moderate, or strong. The variables between which the correlation analysis was conducted were measured on a nominal or ordinal scale, thus limiting 
the applicability of measures for qualitative scales. The following were used:

- Chi-square test of independence - the measure of correlation for characteristics measured on any measurement scale but recorded in the form of a correlation table (measurement is broad and applied mainly for qualitative scales); the measure verifies the hypothesis that there is no relationship between the variables tested; on that basis, the following measures are determined: Phi coefficient, contingency coefficient, Cramer's V coefficient (these measures assess the strength of correlation); a measure of chi-square requires some important assumptions, in particular a large sample and a non-zero number in the correlation table;

- Somers' D - a correlation measure used to assess the direction and strength of the relationship between variables measured on at least an ordinal scale; the measure sign indicates the direction of the relationship and the value of the measure (from -1 to +1 ) indicates its strength;

- Spearman's rank correlation coefficient - a correlation measure used to assess the direction and strength of the relationship between variables measured at least on an ordinal scale; the measure sign indicates the direction of the relationship and the value of the measure (from -1 to +1 ) indicates its strength. It is the equivalent of the Pearson's linear correlation coefficient when calculations are performed not on the actual values of the statistical characteristics, but on the ranking of these characteristics.

Cluster analysis is a hierarchical method, the aim of which is to group objects by the selected characteristics so that there are very similar objects within the focus because of the selected characteristics, while the clusters themselves should vary. ${ }^{1}$

Cluster analysis is a multidimensional method of data mining. Its purpose is to detect unobservable factors that are hidden within the analyzed dataset. Another equally important goal of analysis is to reduce overdimensionality, that is, to reduce the input data set to several uncorrelated factors that will explain as much of the variability of the input set as possible. The research uses a principal component analysis, which creates a linear combination of input variables so that the first factor explains the largest part of the variability of the input set, while another factor, which is not correlated with the first one, explains the remainder of the variability, etc. ${ }^{2}$ The research also uses the orthogonalization of factors, i.e. the rotation of the system so that the factors are uncorrelated and easily interpretable. ${ }^{3}$ 


\subsection{Experience of Selected Enterprises in Family Business Reputation Management}

\subsubsection{Stakeholder Orientation}

Family businesses operate in a specific model of internal (familycompany) and external relationships. The dialogue with various stakeholder groups enables them to strengthen their market position and gain knowledge of the requirements of individual groups with different business priorities in the future. Given that companies are not able to meet all expectations of each stakeholder group to the same extent, it is important to consciously identify the groups of partners with who the company intends to build effective relationships based on shared values. The process of value creation involving stakeholders should include their identification, the definition of common areas of interest, objectives and benefits, as well as the challenges faced by the company in building relationships with these groups.

Taking the real impact of individual groups in the organization's environment on its functioning and results into account, the representatives of family businesses in the survey identified two groups: one group of greater importance to them, including customers, employees, investors and business partners, and a second group of minor importance, including local communities, media and public and local administration.

Customers are most frequently mentioned as the key stakeholders who have the greatest influence on the functioning of the family business more than three-quarters of respondents consider this group to be the most important (Table 4.2). 87.3\% of representatives of service companies responded thus, compared to $63.8 \%$ of those representing production companies, a difference which may be explained by a completely different relationship with the end users of their products. A large proportion of the representatives of micro-family businesses and B2B companies $(80.0 \%$ and $79.3 \%$ respectively) also responded in this way - Tables 4.2 and 4.3 . If customers who share the values of an organisation are centred around the company, a value-based community is created. If the value system is close to the value system of customers, building loyalty results in profit in the long term. Such concentration is the key to economic performance.

The second most frequently mentioned group of stakeholders is family business employees. This group is usually identified by the representatives of production companies $(27.7 \%)$ compared to trade $(20.0 \%)$ and service companies $(11.1 \%)$. The essential impact which employees have on the functioning and financial performance of the family business is more often highlighted by family businesses operating on the B2B market than the B2C market $19.5 \%$ and $17.5 \%$ respectively), as well as the representatives of large family businesses employing 250 people or more (Table 4.3). 


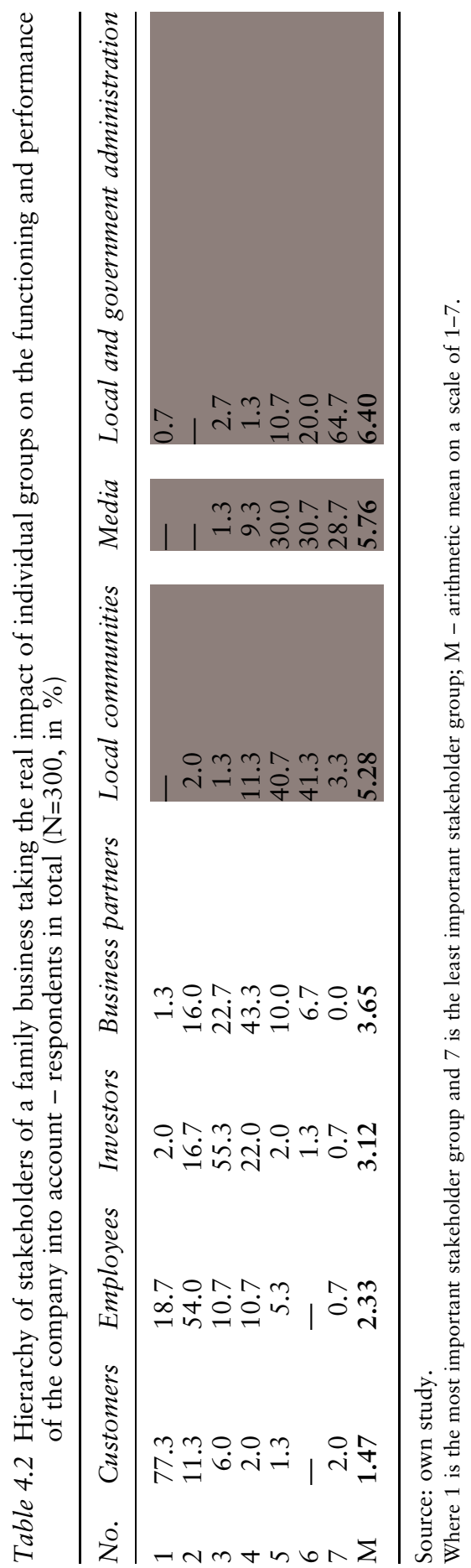




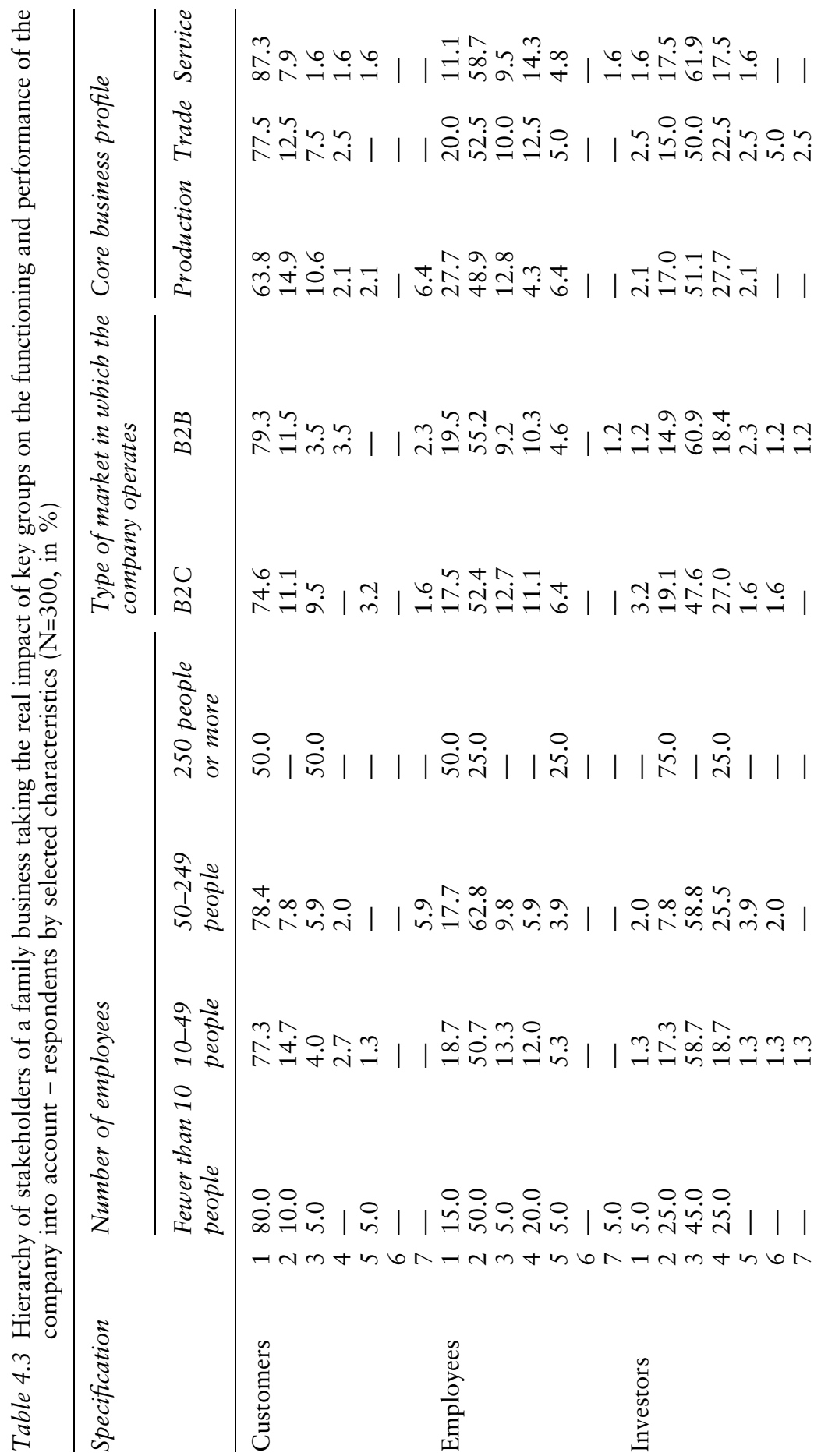




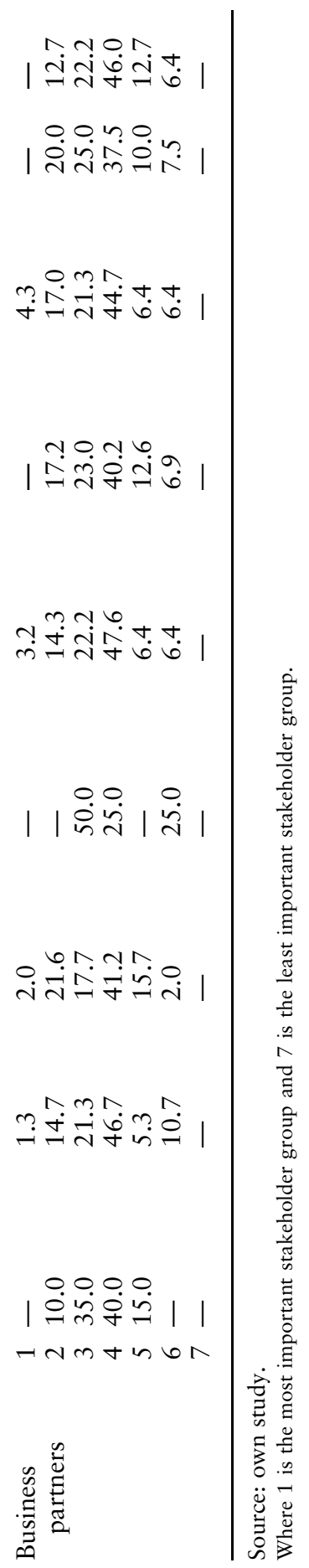


Only in third and fourth place respectively were investors and business partners indicated by respondents. The least important stakeholder groups are local communities, the media and public administration at different, central, regional or local levels - Table 4.2. Family businesses note the fact that employees whose identification with the company results from the acceptance of its mission, standards and values create value that increases the chances of building a competitive advantage.

Family businesses, when managing reputation, should recognize the real impact of individual stakeholder groups on the functioning and performance of the company and follow shared values in their activities. Therefore, in the subsequent part of the survey, respondents were asked about the values that individual stakeholder groups expect family businesses to respect. The results obtained are summarized in subsequent columns of Table 4.4, starting with the most important group of stakeholders -family business customers.

According to the respondents, family business customers expect them to be fair in pricing $(81.3 \%)$, offer high-quality products and services $(81.0 \%)$, as well as high-quality customer service $(80.7 \%)$. However, employees of family businesses expect them to respect completely different values. This primarily pertains to profitability $(82.7 \%)$, concern for employees $(82.3 \%)$ and ethical behaviour of board members and employees $(78.7 \%)$. According to the respondents, investors' expectations are similar to those of employees. Profitability $(83.3 \%)$ and financial and economic stability and ethics $(78.7 \%)$ should be the priority here. On the other hand, when referring to the expectations of business partners, respondents most often pointed to values such as respect for competition $(82.0 \%)$, transparency and openness (77.3\%), as well as the ethical behaviour of the management and employees of family businesses (76.7\%).

When managing corporate reputation, it is difficult not to take into account criteria/determinants that are considered by stakeholders when assessing the company and thus affecting the level of its assessment. For respondents who represent family businesses, this issue was very important and difficult at the same time. It was important, as all 23 determinants presented for evaluation reached an average of more than 5.50 on a seven-point scale. Moreover, apart from one indicator, defined as "internationalization of the company", none of the 300 respondents indicated, by assessing the others, the two lowest values on the scale. It is difficult, because the gap between the highest-rated value "quality of products and services" and the lowest-rated value "internationalization of the company" is only 0.38 (Table 4.5). This means that, in the opinion of the respondents, all the factors listed in Table 4.5 should be taken into account in order to ensure a good corporate reputation, and are important to a similar extent.

The subsequent step involved factor analysis, the aim of which was to detect unobservable factors that are hidden within the analyzed data set 
Table 4.4 Identification of expectations of key stakeholder groups about the respect for certain values shown by family businesses - opinions of respondents $(\mathrm{N}=300$, in \%)

\begin{tabular}{|c|c|c|c|c|}
\hline Specification & Customers & Employees & Investors & $\begin{array}{l}\text { Business } \\
\text { partners }\end{array}$ \\
\hline Fairness in pricing & 81.3 & 62.0 & 72.7 & 68.0 \\
\hline $\begin{array}{l}\text { High quality of products } \\
\text { and services }\end{array}$ & 81.0 & 59.0 & 74.7 & 62.7 \\
\hline $\begin{array}{l}\text { High level of customer } \\
\text { service }\end{array}$ & 80.7 & 67.3 & 76.0 & 64.0 \\
\hline Business ethics & 78.7 & 73.3 & 78.7 & 70.0 \\
\hline $\begin{array}{l}\text { Reliability, punctuality, } \\
\text { solidity }\end{array}$ & 74.7 & 63.0 & 76.0 & 76.0 \\
\hline Transparency and openness & 74.0 & 64.7 & 75.3 & 77.3 \\
\hline Innovation, uniqueness & 70.0 & 51.3 & 67.3 & 44.0 \\
\hline $\begin{array}{l}\text { Corporate social } \\
\text { responsibility }\end{array}$ & 69.3 & 65.0 & 72.3 & 62.0 \\
\hline $\begin{array}{l}\text { Sustainable development, } \\
\text { care for the environment }\end{array}$ & 65.7 & 66.0 & 77.3 & 71.3 \\
\hline $\begin{array}{c}\text { Ethical behaviour of board } \\
\text { members and employees }\end{array}$ & 65.3 & 78.7 & 77.3 & 76.7 \\
\hline Respect for competition & 61.7 & 69.3 & 74.0 & 82.0 \\
\hline $\begin{array}{l}\text { Respect for business } \\
\text { partners }\end{array}$ & 58.0 & 62.0 & 74.3 & 76.0 \\
\hline $\begin{array}{l}\text { Financial and economic } \\
\text { stability }\end{array}$ & 56.0 & 71.3 & 82.3 & 68.7 \\
\hline $\begin{array}{l}\text { High quality of } \\
\text { management, economy }\end{array}$ & 42.0 & 78.3 & 78.3 & 64.7 \\
\hline Care for employees & 41.0 & 82.3 & 67.7 & 42.7 \\
\hline Internationalization & 41.0 & 56.3 & 75.0 & 72.0 \\
\hline Profitability & 18.0 & 82.7 & 83.3 & 57.3 \\
\hline No response & 0.7 & 0.7 & 1.3 & 2.0 \\
\hline
\end{tabular}

Source: own study.

and to reduce overdimensionality (i.e. reducing the input data set to several uncorrelated factors that will explain as large a part of the variability of the input set as possible). Factor analysis was conducted with the following assumptions:

- the method of isolating the main components;

- number of factors: 5;

- rotation: Varimax;

- factor loadings: minimum level of 0.5 .

The Kaiser-Mayer-Olkin test indicated a suitable selection of elements for the sample. Bartlett's test of sphericity shows that the correlation matrix between variables is not singular, so factor analysis can be used. 


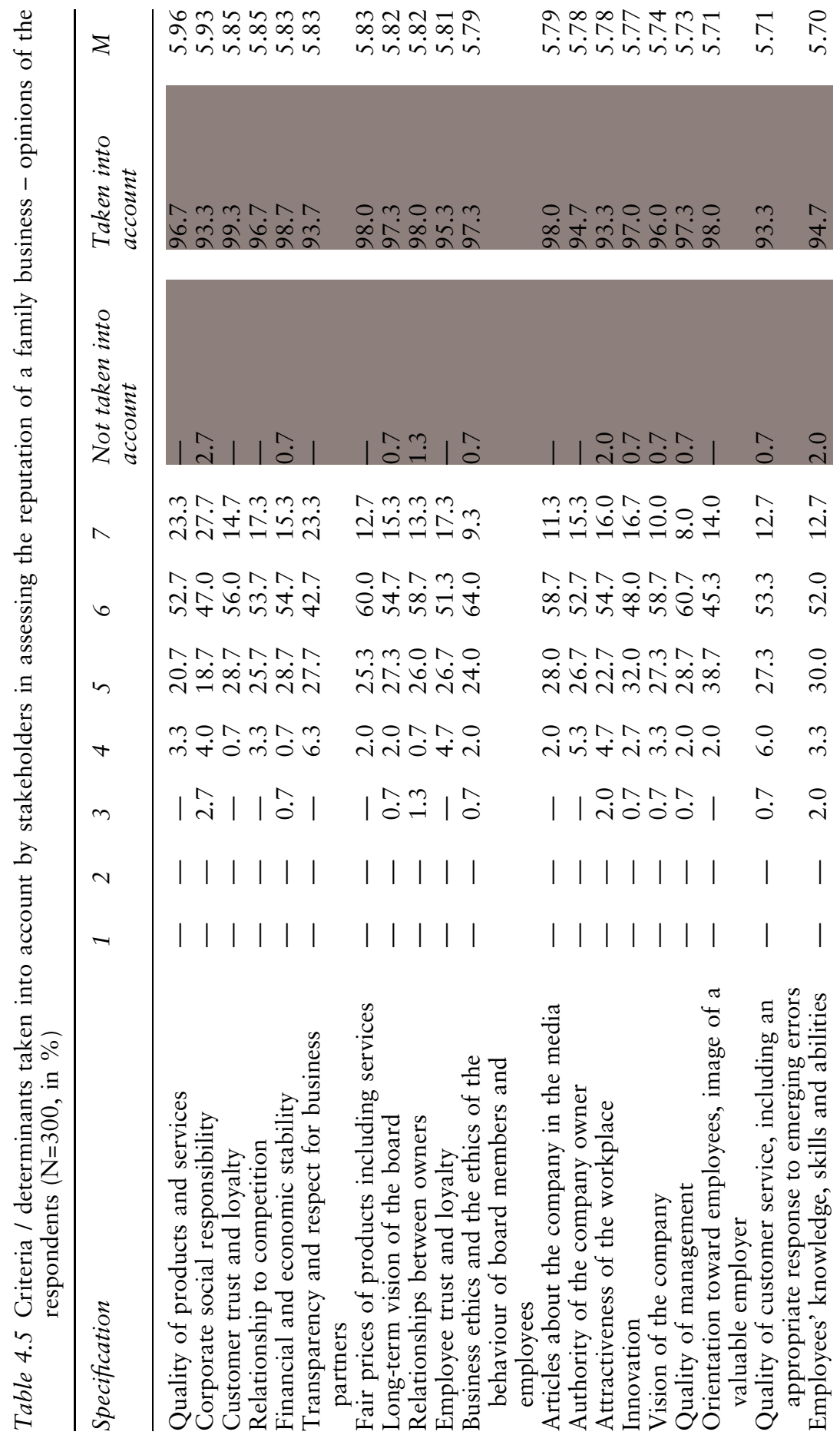




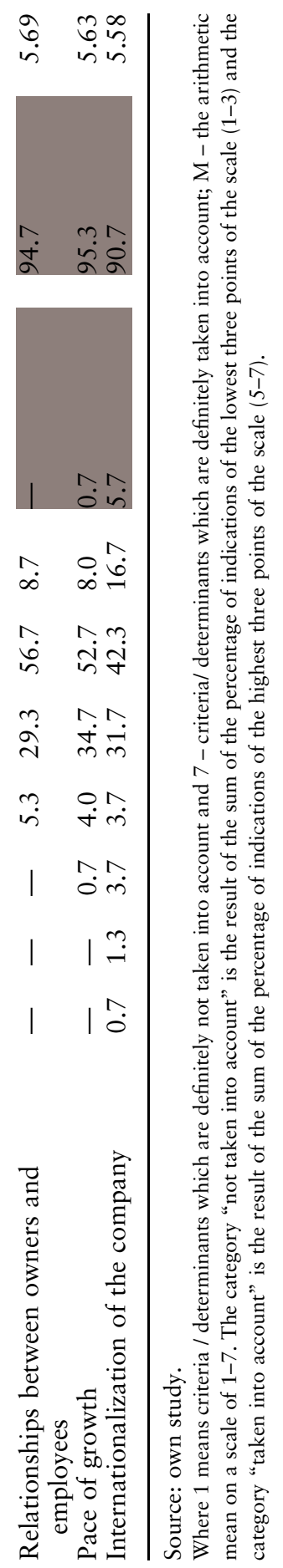




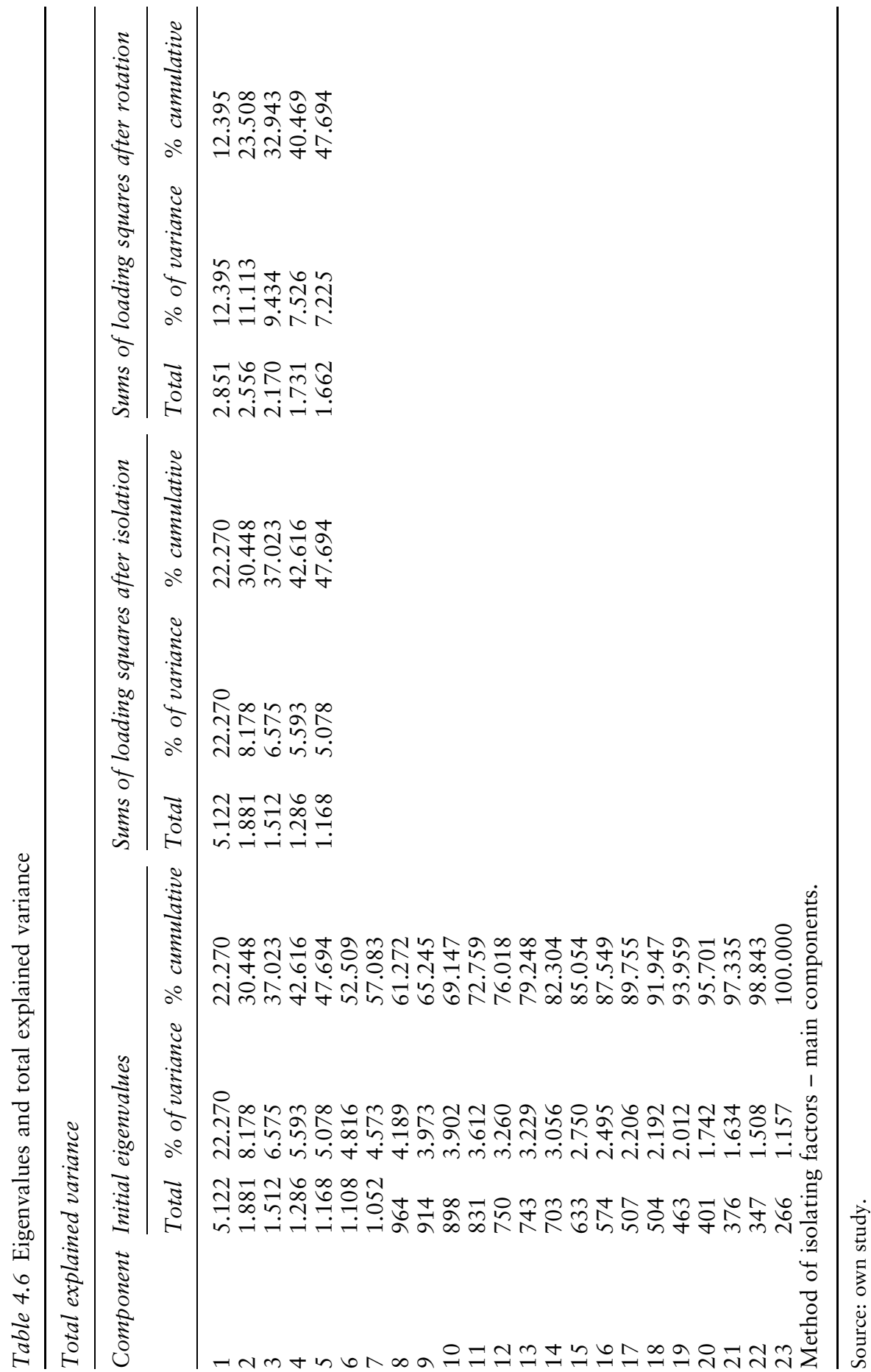


Table 4.7 Rotated component matrix (varimax rotation)

Rotated component matrix

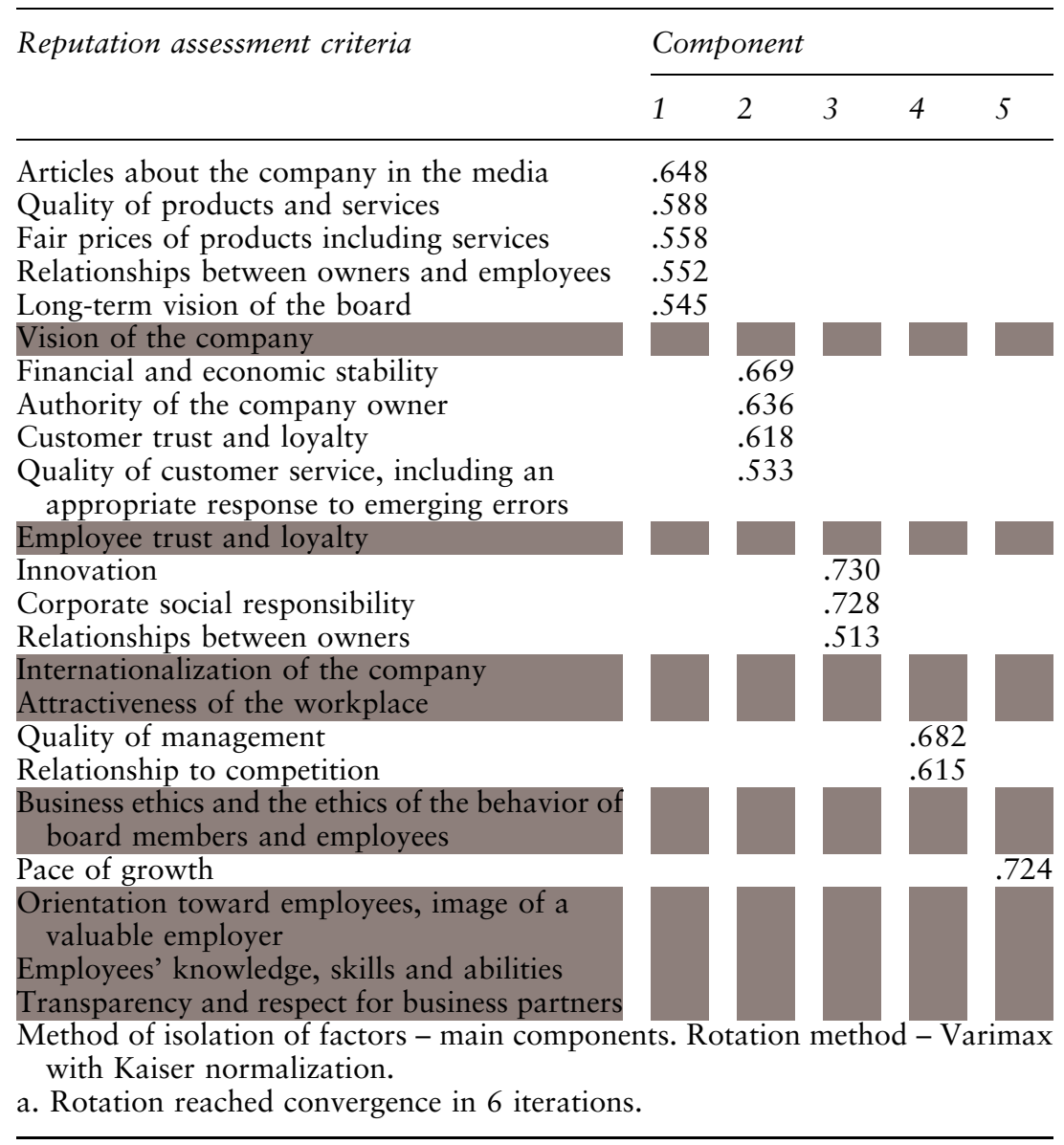

Source: own study.

The results in Tables 4.6 and 4.7 indicate that five factors explain approximately $48 \%$ of the variability of the input data set.

After the elimination of variables poorly correlated with factors, a set of 12 variables was obtained for which factor analysis was performed. The four factors created explain nearly $56 \%$ of the variability of the input data set (Tables 4.8 and 4.9).

The data in Table 4.9 indicate that, in terms of substantive similarity, assessment criteria for reputation are generated by the following factors:

1. related to the development of intra-organization stability, which is the basis for ensuring long-term functioning; 


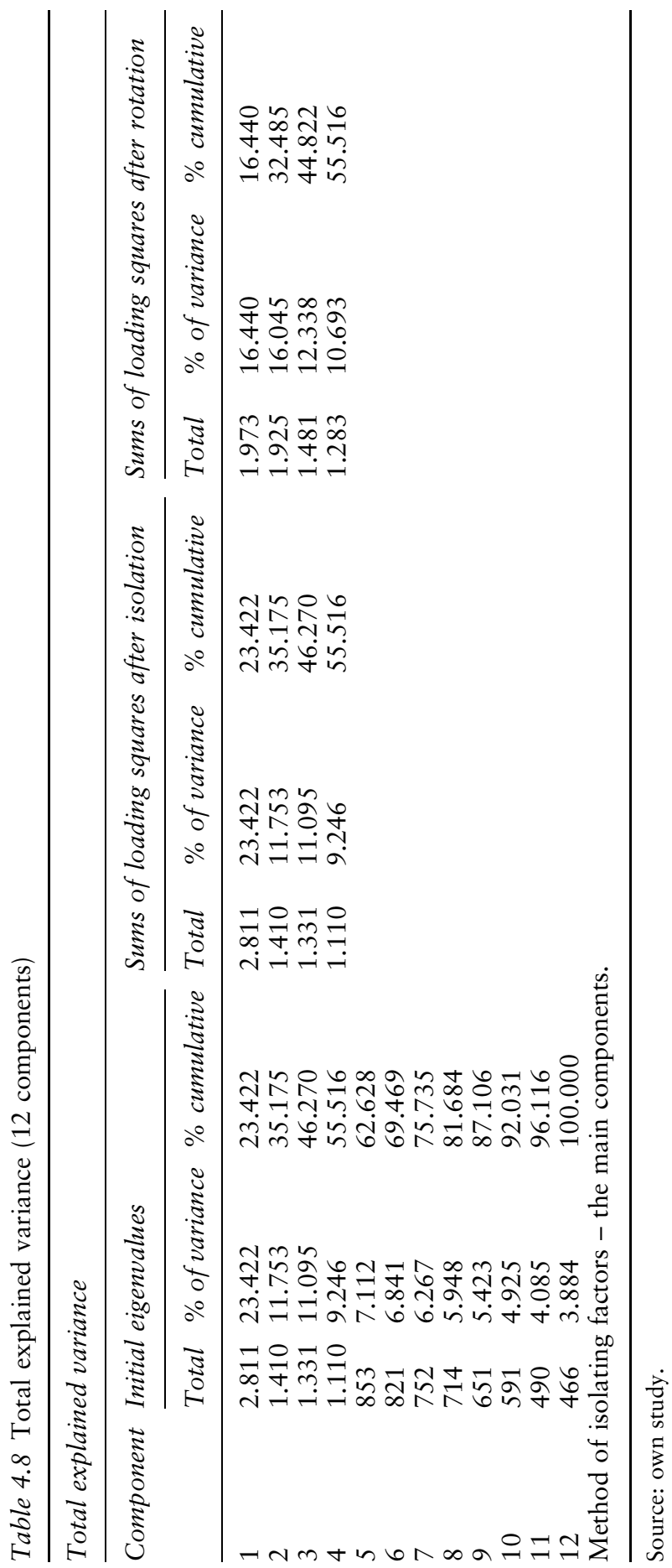


Table 4.9 Rotated component matrix (varimax rotation)

Rotated component matrix

\begin{tabular}{|c|c|c|c|c|}
\hline \multirow[t]{2}{*}{ Reputation assessment criteria } & \multicolumn{4}{|c|}{ Component } \\
\hline & 1 & 2 & 3 & 4 \\
\hline Authority of the company owner & .717 & & & \\
\hline Financial and economic stability & .678 & & & \\
\hline $\begin{array}{l}\text { Quality of customer service, including an appropriate } \\
\text { response to emerging errors }\end{array}$ & .643 & & & \\
\hline Employee trust and loyalty & .618 & & & \\
\hline Long-term vision of the board & & .716 & & \\
\hline Articles about the company in the media & & .704 & & \\
\hline Relationships between owners and employees & & .595 & & \\
\hline Fair prices of products and services & & .581 & & \\
\hline Innovation & & & .769 & \\
\hline Corporate social responsibility & & & .764 & \\
\hline Relationship to competition & & & & .759 \\
\hline Quality of management & & & & .674 \\
\hline $\begin{array}{l}\text { Method of isolating factors - main components. Rot } \\
\text { with Kaiser normalization. }\end{array}$ & tion & ethod & & \\
\hline
\end{tabular}

Source: own study.

2. related to building relationships with individual stakeholder groups;

3. related to the company going beyond established patterns, demonstrating the openness and willingness to develop the company;

4. related to the improvement of the company's functioning.

\subsubsection{Knowledge of Factors which Influence Reputation}

The concept of corporate reputation is presented in literature and interpreted in different ways. In the course of the research, representatives of family businesses were asked how to define the concept of "corporate reputation". The results obtained are presented in Table 4.10.

The respondents agreed with all the terms proposed during the study all definitions presented to them were accepted by a minimum of $90.0 \%$ of the respondents. In the opinion of the respondents, the essence of corporate reputation is the term "source of competitive advantage" (average score of 6.02). Terms such as: "the essence, crystallization of what a company is, how it functions and how it communicates with its stakeholders", "the way the company is perceived and assessed by stakeholders that can attract loyal customers" and "intangible assets" of a company were almost commonly accepted by the representatives of family businesses who took part in the survey (above 95.0\%). The 


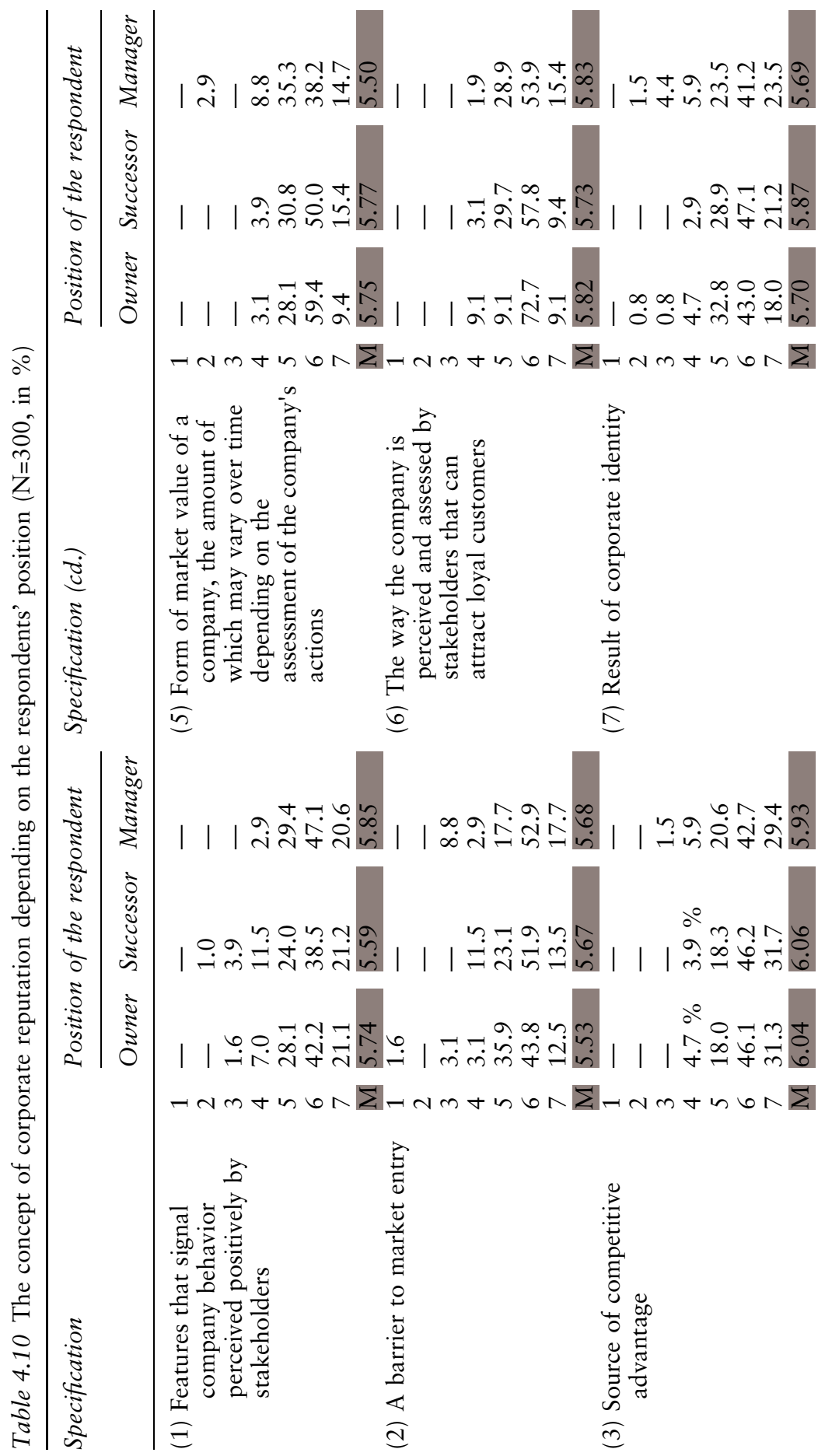



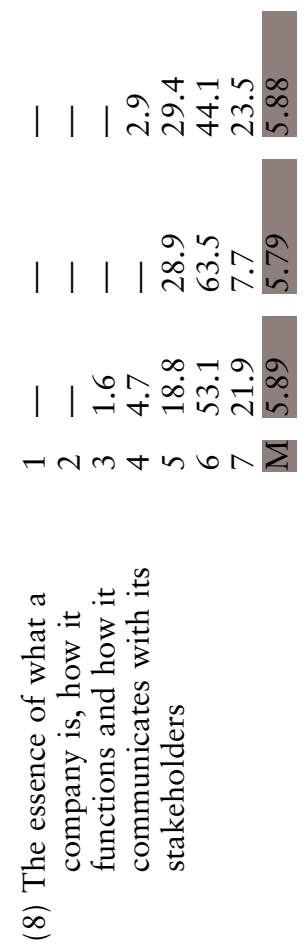

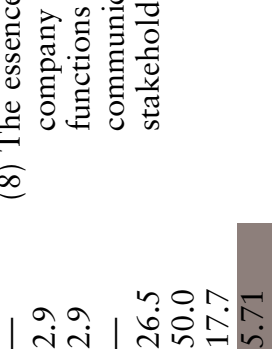

$$
\text { | }
$$

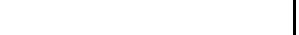

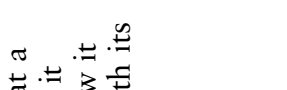

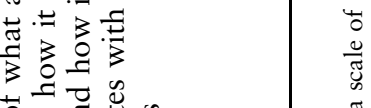
. की

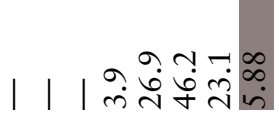




\section{Family Business Reputation Management}

Table 4.11 Factors which influence the strengthening of the reputation of a family business - respondents' opinions ( $\mathrm{N}=300$, in \%)

\begin{tabular}{|c|c|c|c|c|c|c|c|c|c|c|}
\hline Specification & 1 & 2 & 3 & 4 & 5 & 6 & 7 & $\begin{array}{l}\text { It has no } \\
\text { positive } \\
\text { influence }\end{array}$ & $\begin{array}{l}\text { It has a } \\
\text { positive } \\
\text { influence }\end{array}$ & $M$ \\
\hline $\begin{array}{l}\text { Positive } \\
\text { relation- } \\
\text { ships } \\
\text { between } \\
\text { owners }\end{array}$ & - & - & 0.3 & 1.0 & 20.0 & 48.7 & 30.0 & 0.3 & 98.7 & 6.07 \\
\hline $\begin{array}{l}\text { Customer } \\
\text { trust and } \\
\text { loyalty }\end{array}$ & - & - & 0.3 & 3.7 & 18.3 & 45.7 & 32.0 & 0.3 & 96.0 & 6.05 \\
\hline $\begin{array}{l}\text { Relationships } \\
\text { between } \\
\text { employees } \\
\text { and owners } \\
\text { affecting the } \\
\text { atmosphere } \\
\text { at work }\end{array}$ & - & - & - & 1.3 & 22.7 & 47.3 & 28.7 & - & 98.7 & 6.03 \\
\hline $\begin{array}{l}\text { Quality of } \\
\text { customer } \\
\text { service, } \\
\text { including an } \\
\text { appropriate } \\
\text { response to } \\
\text { emerging } \\
\text { errors }\end{array}$ & - & - & - & - & 22.0 & 53.3 & 24.7 & - & 100.0 & 6.03 \\
\hline $\begin{array}{l}\text { Quality of } \\
\text { products or } \\
\text { services }\end{array}$ & - & - & - & 2.0 & 20.7 & 58.7 & 18.7 & - & 98.0 & 5.94 \\
\hline $\begin{array}{l}\text { Employee } \\
\text { trust and } \\
\text { loyalty }\end{array}$ & - & - & 0.7 & 2.7 & 20.7 & 60.0 & 16.0 & 0.7 & 96.7 & 5.88 \\
\hline $\begin{array}{l}\text { Transparency } \\
\text { and } \\
\text { coherence of } \\
\text { action }\end{array}$ & - & - & 0.3 & 5.7 & 25.0 & 44.0 & 25.0 & 0.3 & 94.0 & 5.88 \\
\hline $\begin{array}{l}\text { Values specific } \\
\text { to the family } \\
\text { business }\end{array}$ & - & - & - & 2.7 & 22.0 & 60.7 & 14.7 & - & 97.3 & 5.87 \\
\hline $\begin{array}{l}\text { Uniqueness of } \\
\text { the products } \\
\text { and services } \\
\text { offered, and } \\
\text { the difficulty } \\
\text { which } \\
\text { competitors } \\
\text { have to } \\
\text { copy them }\end{array}$ & - & - & 0.7 & 4.7 & 23.3 & 54.7 & 16.7 & 0.7 & 94.7 & 5.82 \\
\hline
\end{tabular}


Table 4.11 (Continued)

\begin{tabular}{lllllllllll} 
Specification & 1 & 2 & 3 & 4 & 5 & 6 & 7 & $\begin{array}{l}\text { It has no } \\
\text { positive has a } \\
\text { influence }\end{array}$ & $\begin{array}{l}\text { It influence } \\
\text { insive }\end{array}$ \\
\hline $\begin{array}{l}\text { A business } \\
\text { strategy } \\
\text { understood } \\
\text { by } \\
\text { stakeholders }\end{array}$ & - & - & - & 6.7 & 24.7 & 54.0 & 14.7 & - & 93.3 & 5.77 \\
\hline
\end{tabular}

Source: own study.

Where 1 means "has no influence on reputation" and 7 "has a great influence on reputation"; M the arithmetic mean on a scale of 1-7. The category "does not have a positive impact" is a result of the sum of the percentage of indications of the lowest three points of the scale (1-3). The category "has a positive impact" is the result of the sum of the percentage of indications of the highest three points of the scale (5-7).

relatively lowest level of acceptance of the respondents (90.0\%) was given to the term defining corporate reputation as a "barrier to market entry". The type of market in which the company operates, the business profile and the size of the company do not significantly differentiate the responses. Table 4.10 show the different views of owners and successors - convergence or differentiation of opinions may indicate the (un)sustainability of long-term reputation-building activities. In this case, the statistical relationship is insignificant.

In corporate reputation management, not only the level of reputation itself is important, but also all the factors that can have a positive impact on it. Ten such factors were assessed by the respondents, and the results obtained are shown in Table 4.11.

Among the factors that have the most positive impact on strengthening the reputation of a family business, the respondents listed positive relationships between owners, customer trust and loyalty, positive relationships between employees and owners and a high level of customer service. All of these factors achieved an average rating above 6.0 on a seven-point scale. For the last of these factors, all 300 respondents agreed that it was a positive factor which strengthened the reputation of a family business (Table 4.11). The results presented thus confirm the results of previous analyses of the hierarchy of family business stakeholders. Customers and employees are the most important stakeholder groups of a family business, and the relationships between them and the owners are among the factors that have the strongest impact on the reputation of a family business.

The first of these factors is particularly emphasized by microentrepreneurs $(90 \%)$, i.e. the smallest type of economic entity, where relationships between the owner and employees are usually particularly intense. They are often small teams where owners perform daily duties together with people they employ, which promotes frequent contacts and 


\section{Family Business Reputation Management}

close relationships. This view is broadly shared by representatives of the management of the companies surveyed who are not owners or successors $(85 \%)$.

The high quality of service (including the response to undesirable situations) is the most important factor in reputation building according to the representatives of service companies $(87 \%)$, which is not surprising, given that they are the most dependent on high levels of customer satisfaction with the quality of service. Services or products offered on the market can often remain similar (at least from the customer's perspective); quality of service is thus a source of competitive advantage and at the same time a decisive success factor in the conditions of strong economic competition.

\subsubsection{Communication with Stakeholders}

Each organization strives to shape a suitable image and positive reputation for itself. They should foster the development of organizations and, above all, be fully coherent and in line with the strategy adopted. A powerful increase in the assimilation of information compared to the speed of their transmission increases the need for bilateral communication. Respondents declare the choice of different communication activities to build and strengthen the reputation of a family business (Table 4.12).

The data distribution in Table 4.13 shows that projects in the field of advertising, PR and image creation are the most common, followed by educational activities and sponsorship of sporting events or (more rarely) cultural events, and subsequently charitable actions, while the various forms of cooperation with the non-governmental sector or social economy entities are the rarest. It is worth mentioning that the above results correspond to the results of other measurements on nationwide samples of Polish economic entities. It turns out that, for example, corporate social responsibility activities are usually conducted using simple, uncomplicated tools such as sponsoring or a traditional charitable model, while more advanced forms of cooperation, such as the outsourcing of services and building subcontracting relationships with social economy entities or third sector organizations, as well as the creation of joint, cross-sectoral socio-economic ventures, are not widespread. It should be noted that companies individualize the choices of marketing communication methods and tools, and each company adapts their choice to their own specificity, product or service specificity, as well as to customers. The entities surveyed most often engage in media advertising campaigns - especially in the case of medium-sized companies $(78 \%)$; production companies $(79 \%)$. They are active on social media and this activity is conducted more often than others $(70 \%)$ by service companies. They also conduct training of employees, participate in industry conferences and others (respondents could list any number of responses, so the results presented do not add up to $100 \%$ ). These results 


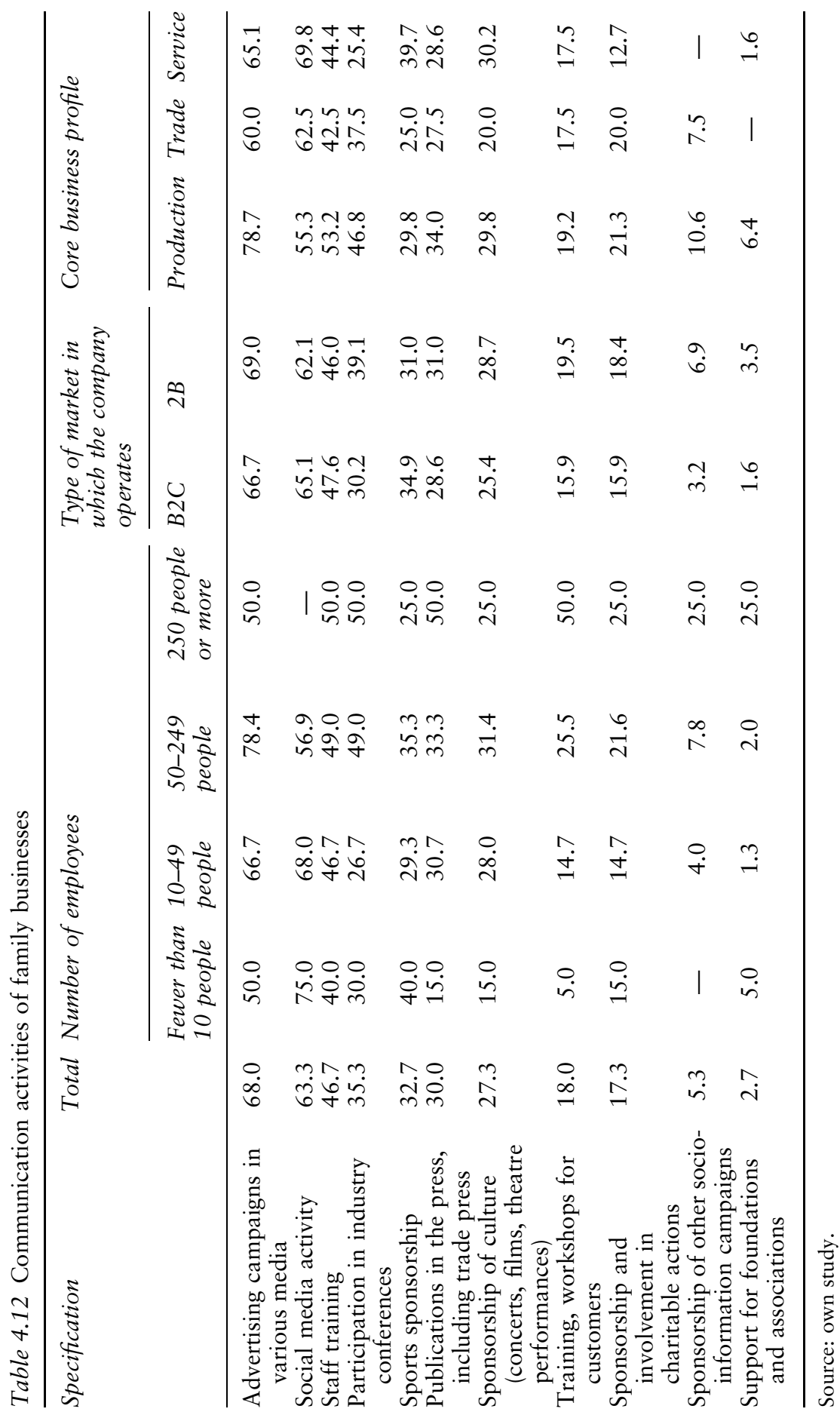




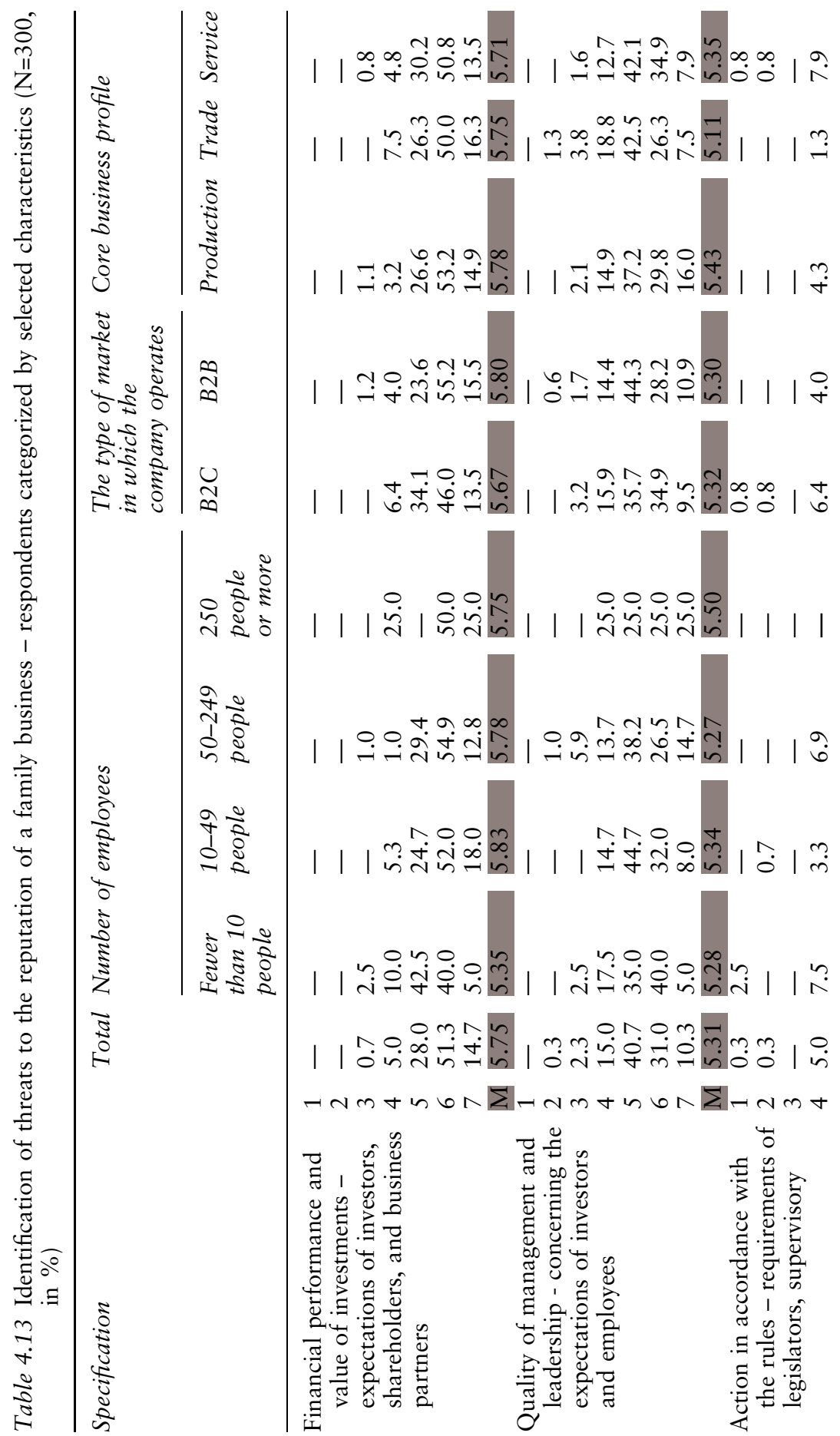


กุe

$0+\infty \hat{\imath}$

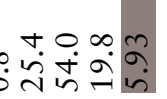

กุำ

4tงin| |

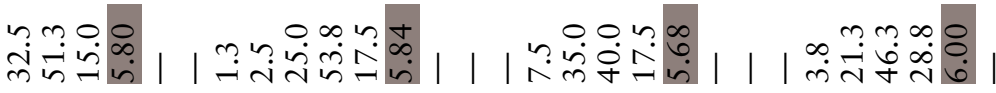

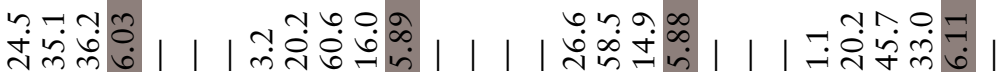

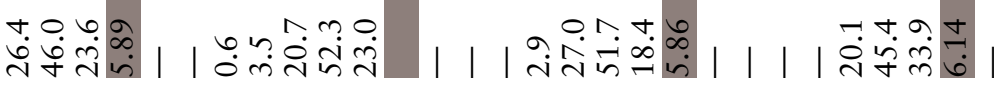

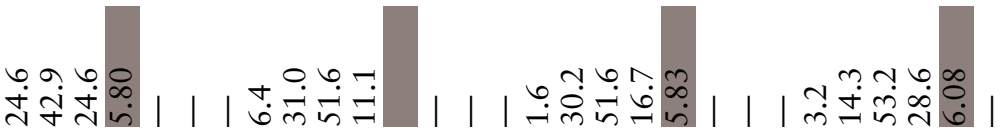

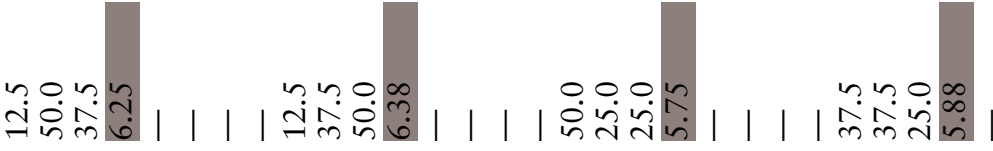

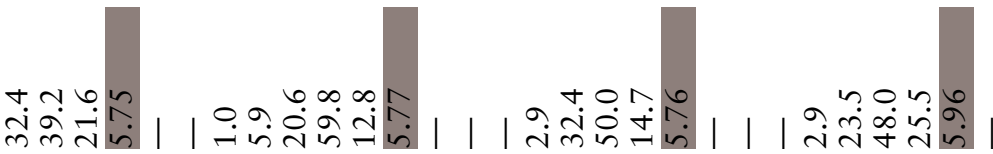

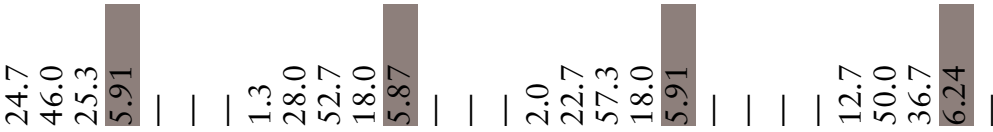

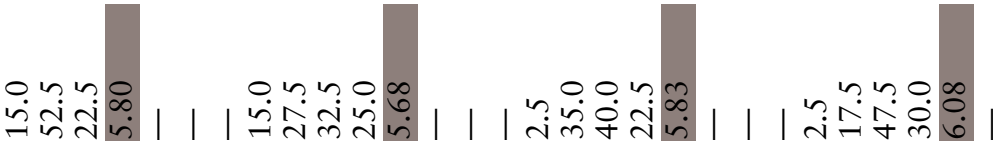

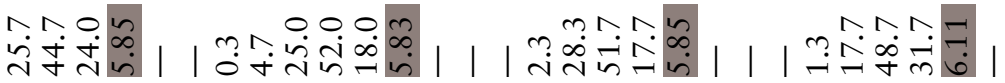
n 6 N

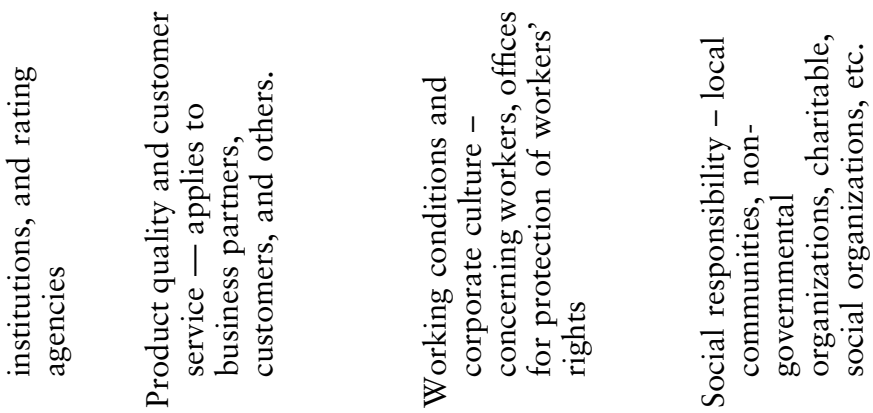




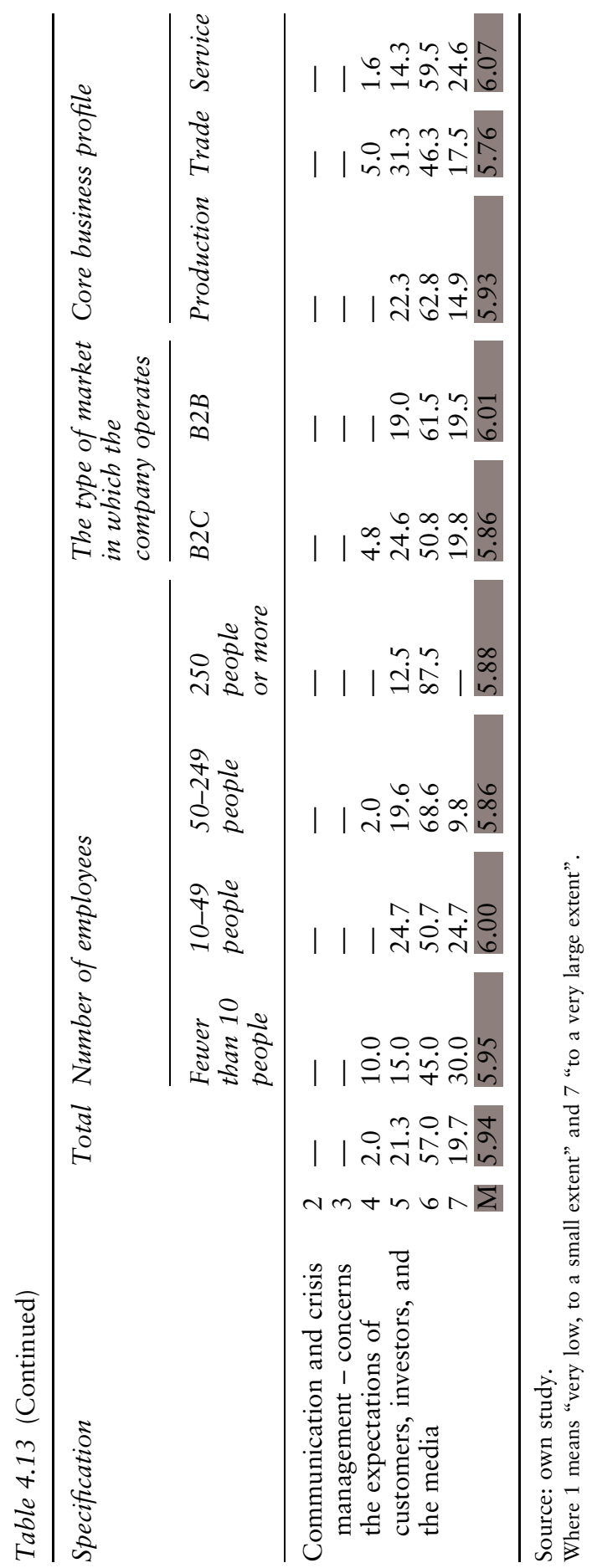


confirm the assumption made in sub-hypothesis 5 that the differentiation of communication channels affects the individualization of reaching different stakeholder groups.

Building a good reputation is a long-term process, but it is easy to damage in a short time. The respondents were asked to indicate the actions to be taken in family businesses to counter the loss of corporate reputation. When analyzing the records of the respondents' statements on their proposed actions to eliminate the risk of loss of reputation, it can be noted that they are primarily targeted at:

- providing customers with high-quality products and services, care for customer satisfaction and care for good relationships with customers;

- honesty, the observance of ethical principles of running a business and reliability;

- transparent rules and high transparency;

- preventing and resolving conflicts.

Offering high-quality products and services is, in the opinion of the respondents, the best action to counteract the loss of corporate reputation. A satisfied customer guarantees a good corporate reputation. The high quality of products offered at a fair price contributes to this. Both customers and other stakeholder groups value honest conduct, transparent company activities and the ethical principles of conduct highly. These activities are closely linked to another important action which respondents pay attention to, namely conflict prevention or a rapid response to irregularities that have already arisen.

Depending on the type of family business, i.e. its profile, size or the type of customer serviced, there may be differences in the first place in the ranking of actions which eliminate the risk of the loss of reputation. Therefore, in the case of family businesses with a production profile and those operating on the $\mathrm{B} 2 \mathrm{~B}$ market, it is essential to take action to prevent and combat conflicts in order not to jeopardize corporate reputation. On the other hand, in the case of companies with commercial and service profiles and operating on the B2C market, first of all, their business should be conducted in a fair manner. Looking at the selfassessment of the economic situation of the family businesses surveyed, family businesses that are in a very good economic situation, first of all, recommend offering high-quality products and services to counteract the loss of reputation. For companies that are in a good situation it is honesty in business which is most highly recommended; for those in a satisfactory situation - actions to prevent conflicts; and for those in a difficult situation - honesty, similarly to those in a good situation. For family businesses in a very difficult situation, the best solution to prevent the loss of reputation is to respond quickly to and prevent the occurrence of irregularities. 


\subsubsection{Reputation-building Strategy}

Reputation management requires controlling "node points" - places where good or bad opinions are created, and the number of points that influence the emergence of opinions are increasing. Reputation is born (and dies) in a highly dispersed environment. The Internet has shifted the centre of power over information which is crucial to organizations and companies from the company to other centres. The Internet and social networks allow bad information to spread, regardless of whether it is true or not, in a very short time. The Internet can equally be a source of reliable and untrue information that bears a striking resemblance to true information. The challenge today is, therefore, not only the question of safeguarding/caring for one's reputation, but also the prevention of the associated risks, which have increased and become more complex. A functional strategy may be a tool for reputation management.

Fewer than four out of ten representatives of the entities surveyed declare that their companies have a well-thought-out and planned reputation management policy. $4 \%$ of companies which participated in the survey have a written strategic document which regulates this problem area - these are medium-sized enterprises, employing between 50 and 249 employees $(8 \%)$, production companies $(11 \%)$ and companies which operate on the B2B market $(4.5 \%)$

Some companies have a reputation management strategy that has not been codified in a separate document, but functions as one of the core principles in the company $(15 \%)$. This is most common in production companies $(23 \%)$, as well as in companies employing 250 or more people $(50 \%)$ and operating on the B2C market $(17.7 \%)$.

In the case of $19 \%$ of the respondents, the elements of the reputation management strategy are scattered, i.e. they are found in other documents covering different areas of the company's operation. These are most often customer service standards, documents which regulate core values, ethical principles in the company, such as an anti-corruption policy, the principles of transparency in behaviour, functional strategies, or principles of cooperation with business partners. They are usually entities which operate on the B2B market, i.e. provide services to other companies $(23 \%) .62 \%$ of the companies surveyed do not take this kind of action. It is clear that the size of the company has a significant impact on the importance of policies to planning reputation-building activities the more employees an economic entity has, the more likely it is to engage in this activity. In the case of micro-enterprises, $90 \%$ do not have a reputation management strategy or elements that are scattered in other documents, while among small and medium-sized enterprises, the percentage is $64 \%$ and $53 \%$ respectively. Similar activities are usually not undertaken by entities in which $91-100 \%$ of shares are in the hands of the owner or his/her family $(65 \%)$. 
It takes many years to build a good reputation, but it can be destroyed by one sudden incident. Therefore, reputation management - as well as the management of risk relating to the loss of one's reputation - is of strategic importance to the company. An element of managing the risk of the loss of reputation is the identification of emerging risks that can directly and strategically affect the implementation of business strategies. Everything that can affect the expectations of stakeholders is a threat to the reputation of a family business. These are "critical/node points" where good or bad opinions are created. The respondents were asked to assess the extent to which different factors may affect the risk of damaging the reputation of a family business, using a seven-point scale. The results obtained indicate that all these factors may be associated with a risk of loss of reputation by a family business. The average ratings obtained on a scale of 1-7 are located in the range of 5.31-6.11. In turn, the acceptance rate of individual risk factors ranges from $41 \%$ to $80 \%$ (cumulative responses 6 and 7), while negative responses ( $1 \& 2$ ) were very rare - Table 4.13 . It is worth noting, however, that the most frequently mentioned risk factors affecting the loss of reputation are those which have a direct impact on the main stakeholder groups of family businesses, i.e. customers and employees. This aspect is mainly highlighted by the representatives of small entities $(87 \%)$, followed by issues pertaining to communication and management in crisis situations, which is a particularly important issue with regard to the expectations of customers, investors or the media. The highest results were obtained among persons who represent service companies $(84 \%)$, as well as companies operating on the B2B market $(81 \%)$.

According to various sources, it is estimated that reputation can account for between $20 \%$ and $90 \%$ of a company's market value. Therefore, one of the objectives of the research was to try to determine what percentage of family business value could be attributed to its reputation. The question was open-ended and the respondents were asked to define the value of reputation understood as "a part of the surplus market value that can be attributed to the perception of a company as a responsible national and global organizational citizen". The results obtained are summarised in Table 4.14. According to representatives of family businesses, the reputation of a family business can account for $46.5 \%$ of its market value on average. However, nearly six out of ten respondents believe that reputation can represent $40-50 \%$ of the market value, while nearly three out of ten believe that this share may exceed half of the company's value. An analysis of the research results shows that, regardless of the number of employees, the respondents believe that reputation accounts for a moderate percentage of the company's value (Table 4.14). The percentage of the respondents who show that this percentage is low is also significant. In the group of the respondents employing at least 250 people, the percentage of the respondents 
Table 4.14 Percentage of the market value of the family business which may be attributed to corporate reputation - assessments of the respondents $(\mathrm{N}=300$, in $\%)$

\begin{tabular}{|c|c|c|c|c|c|}
\hline \multirow[t]{2}{*}{ Specification } & \multicolumn{5}{|c|}{ Range of values } \\
\hline & $0-20 \%$ & $20-40 \%$ & $40-60 \%$ & $60-80 \%$ & $80-100 \%$ \\
\hline \multicolumn{6}{|l|}{ Number of employees } \\
\hline Fewer than 10 people & - & 35.0 & 57.5 & 7.5 & - \\
\hline $\begin{array}{l}\text { Between } 10 \text { and } 49 \\
\text { people }\end{array}$ & 6.7 & 40.7 & 45.3 & 7.3 & - \\
\hline $\begin{array}{l}\text { Between } 50 \text { and } 249 \\
\text { people }\end{array}$ & 2.0 & 36.3 & 57.8 & 3.9 & - \\
\hline 250 or more people & 25.0 & 25.0 & 37.5 & 12.5 & - \\
\hline \multicolumn{6}{|c|}{ Type of market in which the company operates (predominant market) } \\
\hline $\begin{array}{l}\text { B2C market } \\
\text { (cooperation with } \\
\text { individual } \\
\text { customers) }\end{array}$ & 4.8 & 43.7 & 49.2 & 2.4 & - \\
\hline $\begin{array}{l}\text { B2B market } \\
\text { (cooperation with } \\
\text { other companies) }\end{array}$ & 4.6 & 33.9 & 52.3 & 9.2 & - \\
\hline \multicolumn{6}{|c|}{ Core business profile (predominant profile) } \\
\hline Production & 5.3 & 44.7 & 44.7 & 5.3 & - \\
\hline Trade & 7.5 & 48.8 & 41.3 & 2.5 & - \\
\hline Service & 4.7 & 26.2 & 61.9 & 9.5 & - \\
\hline \multicolumn{6}{|l|}{ Ownership structure } \\
\hline $\begin{array}{l}91 \% \text { to } 100 \% \text { in the } \\
\text { hands of the owner } \\
\text { or his/her family }\end{array}$ & 4.0 & 38.2 & 52.6 & 5.1 & - \\
\hline $\begin{array}{l}76 \% \text { to } 90 \% \text { in the } \\
\text { hands of the owner } \\
\text { or his/her family }\end{array}$ & - & 25.0 & 56.3 & 18.8 & - \\
\hline $\begin{array}{l}51 \% \text { to } 75 \% \text { in the } \\
\text { hands of the owner } \\
\text { or his/her family }\end{array}$ & 37.5 & 25.0 & 12.5 & 25.0 & - \\
\hline \multicolumn{6}{|c|}{ Overall assessment of the economic situation of the family business } \\
\hline Very good & - & 20.0 & 60.0 & 20.0 & - \\
\hline Good & 2.7 & 31.8 & 58.6 & 6.8 & - \\
\hline Satisfactory & 10.9 & 59.4 & 26.6 & 3.1 & - \\
\hline Difficult & - & 75.0 & 25.0 & - & - \\
\hline Very difficult & 50.1 & 50.0 & - & - & - \\
\hline \multicolumn{6}{|c|}{ Year in which the company was established } \\
\hline 2011 and later & 5.8 & 38.6 & 48.7 & 6.9 & - \\
\hline $2000-2010$ & 3.2 & 36.8 & 54.7 & 5.3 & - \\
\hline 1989-1999 & - & 40.0 & 50.0 & 10.0 & - \\
\hline $1945-1988$ & - & 25.0 & 75.0 & - & - \\
\hline Before 1945 & - & 50.0 & 50.0 & - & - \\
\hline
\end{tabular}

Source: own study.

Where: $0-20 \%$ means a very low percentage, $20-40 \%$ low, $40-60 \%$ moderate, $60-80 \%$ high, $80-100 \%$ very high. 
indicating that reputation accounts for a very low percentage of company value is also important. ${ }^{4}$

The results of the analysis also show that, regardless of the age of companies, the respondents believe that reputation accounts for a moderate or low percentage of the company's total value.

A similar situation can be observed on the market in which the company operates. Regardless of whether it pertains to the B2B or the B2C market, the respondents believe that their reputation accounts for a low or moderate percentage of the company value, whereas among the respondents who indicate that their company is active on the B2B market, the largest number are of the opinion that a moderate percentage of the value of a company is attributable to reputation.

The analysis of the results by the predominant business profile indicates that the respondents who represented family businesses with a production or trade profile believe that reputation accounts for a low or moderate percentage of the company value. On the other hand, the respondents speaking on behalf of service family businesses believe that reputation accounts for a moderate percentage of the company value. The results of the analysis show that there is no link between the ownership structure and the assessment of the share of reputation in company value. Among respondents with an ownership share of between $76 \%$ and $100 \%$, the contribution of reputation to the company value is assessed as moderate or low, while among those with ownership of $51-75 \%$ of a company, the share of company value attributed to reputation is very low. In addition, the results of the analysis show that in the group of the respondents who assess the economic situation of their family business as very difficult, the share of reputation in company value is rated as low or very low. The respondents who assess their economic situation as difficult or satisfactory indicate that the share of reputation in company value is low. On the other hand, the respondents who assess the economic situation as good or very good think that reputation accounts for a moderate percentage of company value (Table 4.15).

Companies will take actions related to reputation management if they are convinced that a good reputation brings a specific benefit. A notable benefit for the company, which translates from having a good reputation, was most often indicated as the increased level of sales of the products or services offered. This belief is most widespread among representatives of trade companies $(85 \%)$ as well as managers in the companies surveyed, but not their owners, nor successors $(82 \%)$. The second most frequently mentioned benefit is the impact on reducing the costs of widely defined marketing activities - in this case the highest results were among the representatives of managerial staff who are not owners or successors $(79 \%)$. The respondents could list any number of indications, so these percentages do not add up to $100 \%$. 


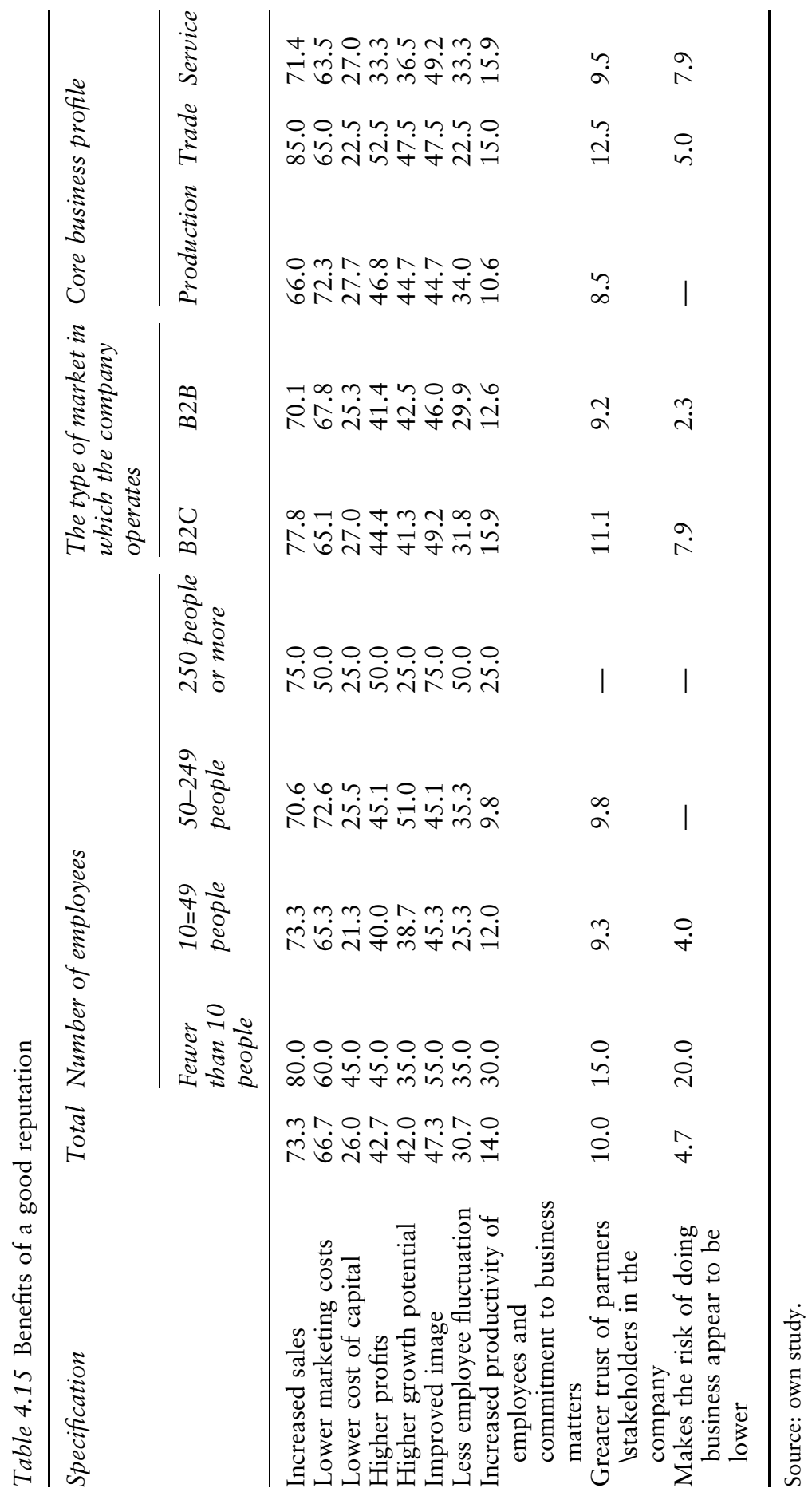




\subsection{The Sustainability of Reputation Management in the Context of Intergenerational Change in the Opinion of Respondents}

Ensuring the sustainability of the reputation of a family business in a situation of intergenerational change is undoubtedly both a major challenge for the owner and a test for his/her successor. It is crucial in the management process of this extremely valuable intangible asset when the owner and successor have a similar family system and business values, a similar understanding of the nature of the reputation or its importance to the operation of the entire company. The managers of a family business shape the culture of the entire organization, set the direction of its development and motivate the team to work more efficiently. The creation of value-based reputation that determines the stability of the team is therefore one of the key competencies that the outgoing owner should delegate to his/her successor. Successors who act prudently, introducing changes in the company gradually and without any haste, are able to continue and develop the family business while maintaining their reputation. Certainly, the outgoing owner (often a parent) will never be sure that the successor will maintain his/her reputation for many years. However, having a successor to the owner/founder who is guided by the same or similar values in both his/her private and professional lives significantly increases the chance of success.

A similar understanding of the nature of reputation itself or the importance of reputation in the management of a family business is therefore crucial in reputation management. The greater the convergence of views in this respect between the owner and the successor, the greater the likelihood that the entire transfer of ownership and power will proceed smoothly and without further damage to the reputation of the family business.

Research conducted in family businesses shows that both owners and successors have a similar understanding of the importance of reputation, which bodes well for such businesses for the future, including the sustainability of their reputation. There were no significant differences in the responses of both the first and second groups of respondents. In the opinion of both owners and successors, reputation is primarily one of the intangible assets of the family business which ensures it a competitive advantage on the market (Figure 4.1). The benefits of a good reputation, according to owners and successors, are shown in Figure 4.2.

The data presented in Figure 4.2 indicate that the members of the ownership family (owner and successor) have similar opinions on the benefits of a good reputation, despite the generation gap. Interestingly, differences are revealed in the opinions of managers who are not members of the ownership family.

Looking at family and business values expressed by the owners and successors of the organizations surveyed, it can be noted that there are no 


\section{Family Business Reputation Management}

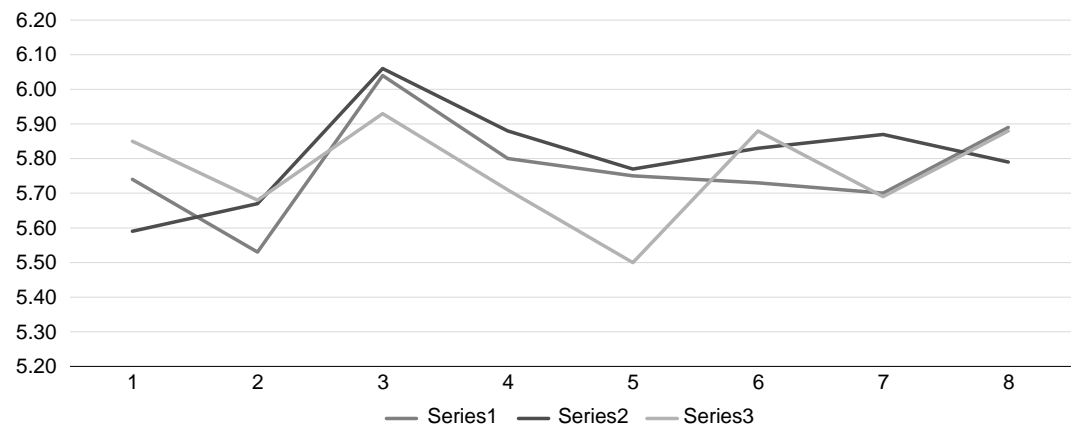

Figure 4.1 The essence of reputation in the opinion of owners and successors

Where: Series 1 - Owner, Series 2 - Successor, Series 3 - Another person (director/manager); (1) characteristics that signal behaviour perceived positively by stakeholders, (2) barriers to market entry, (3) the source of competitive advantage, (4) intangible assets, (5) the form of market value of a company, the amount of which may be subject to changes over time depending on the assessment of the company's activities, (6) the way the business is perceived and evaluated by stakeholders who can attract loyal customers, (7) the result of corporate identity, (8) the essence of what the company is, how it operates and communicates with its stakeholders

Source: own study

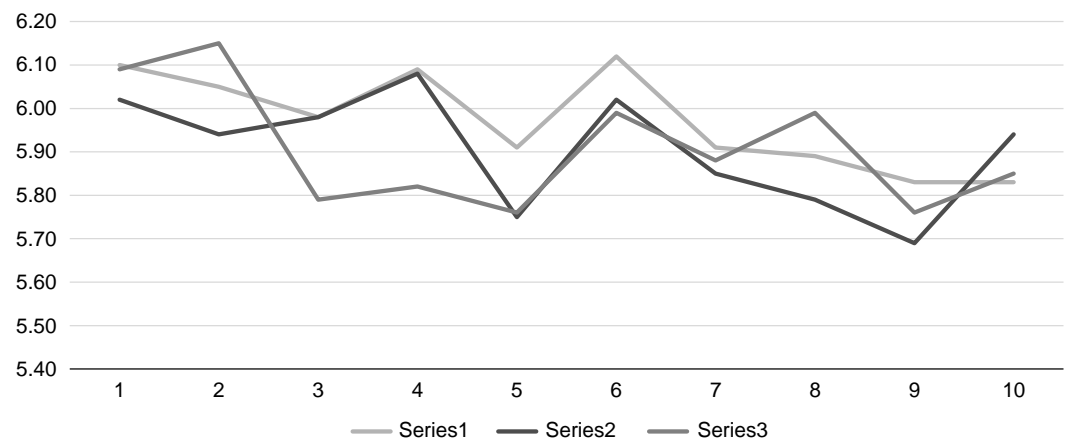

Figure 4.2 The benefits of good reputation - according to owners and successors

Where: Series 1 - Owner, Series 2 - Successor, Series 3 - Another person (director/manager); (1) positive relationships between owners or conflicts occurring, (2) relationships between employees and owners which affect the atmosphere at work, (3) quality of products or services, (4) quality of customer service, including appropriate responses to emerging errors, (5) uniqueness of products and services offered and the difficulty competitors have in copying them, (6) customer trust and loyalty, (7) employees trust and loyalty, (8) transparency and consistency in action, (9) business-specific strategy, (10) values characteristic of a family business

Source: own study 


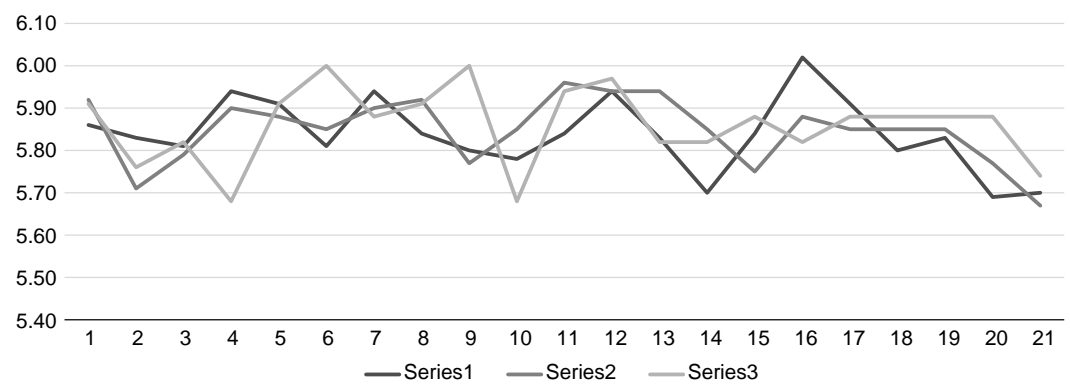

Figure 4.3 Family business value - declarations of owners and successors

Where Series 1 - Owner, Series 2 - Successor, Series 3 - Another person (director/manager); (1) Respect, (2) Loyalty, (3) Entrepreneurship, (4) Experience, (5) Responsibility, (6) Good atmosphere, (7) Reliability, (8) Good relationships between family members, (9) Stability, (10) Heritage and sustainability, (11) Profit, (12) Common objectives, (13) Trust, (14) Family reputation, (15) Honor of the company, (16) Integrity towards stakeholders, (17) Transparency in action, (18) Coherent image, (19) Education, knowledge, (20) The welfare of employees who are not members of the owner's family

Source: own study.

significant differences between the two groups. Small discrepancies can be observed in relation to values such as loyalty, stability or the honour of a company. For $97 \%$ of successors, loyalty is the most important value in the company which is conducive to building the reputation of family businesses, while at the same time $90 \%$ of the owners surveyed indicated such a response. Stabilization was important for $98 \%$ of successors and $94 \%$ of owners, while honour was the most important value for $98 \%$ of owners and $94 \%$ of successors (Figure 4.3 ). The absence of significant differences in this respect may imply that the succession process in the companies surveyed will proceed smoothly and without further damage to the reputation of the family business.

According to the owners and successors surveyed, the reputation of a family business is strengthened mainly by factors such as the quality of customer service, including an appropriate response to emerging errors (in the case of owners and successors, the highest responses - from 5 to 7 - each received $100 \%$ ). The biggest difference was seen in the case of a reputation-strengthening factor, i.e. "business strategy understood by stakeholders". Only $8 \%$ of successors considered this a factor that has a very high impact on the reputation of the family business, unlike the owners surveyed - for $20 \%$ of owners this factor is very important.

In the opinion of the vast majority of the owners $(81 \%)$ and successors $(79 \%)$ surveyed, the reputation of the family business has an impact, first of all, on building the position of a valuable employer. It also plays an 
important role in building and strengthening customer loyalty. In the opinion of nearly half of the owners surveyed $(47 \%)$, a good reputation attracts positive investors and facilitates cooperation with the best customers $(47 \%)$. However, the responses of successors in this respect differed significantly - indicated by $21 \%$ and $29 \%$ of successors respectively. This probably results from a lack of experience between the transferring owner and the successor who takes over. According to both groups, a positive reputation translates primarily into higher sales and lower marketing costs.

The research shows very clearly that both the owners and successors who participated in the survey have a very similar approach to the issue of reputation and, importantly, they follow similar values in business. As a result, intergenerational change is likely to proceed without further damage to corporate reputation. The research also shows that the intergenerational change will be geared towards four organizational trends:

- the need to improve quality and customer orientation;

- the need for professional autonomy and responsibility;

- the need for evolution from bosses to leaders;

- the need for a flatter and more agile organizational structure.

In this chapter, the various elements of the proposed reputation management concept have been subjected to empirical verification. In view of the multiplicity of approaches to reputation and the management thereof, it was important to determine how the concept functions in the awareness of respondents.

For the vast majority of the respondents, regardless of the company's profile, age, size and respondent, reputation is understood as a source of competitive advantage. The respondents (almost to a man) believe that internal and external factors have a positive impact on its level. Both the functioning of the organization itself (interpersonal relations, values, quality of products and services and business strategy) and market perception (trust, clear signals, transparency in action) are important to them.

According to the respondents, the most important stakeholders with an impact on reputation are customers, and to a lesser extent employees, as well as investors and business partners.

The natural consequence of further investigations was to determine what values are most appreciated by the most important stakeholder groups. In the opinion of family business owners, stakeholders differ in terms of their expectations as to the significance of important values. According to the respondents, the most important values for customers are the price, quality of products and services and the level of service. Employees point to the ethics of the board members, care for employees 
and profitability, while investors appreciate profitability and ethical and good management. Respect for competition, the ethical behaviour of all employees, as well as transparency and openness are important to business partners. All these elements deserve recognition and play a major role in building reputation, so they should be lasting components of reputation management that contribute to the company's success.

An attempt was also made to determine what criteria were taken into account by the representatives of family businesses when formulating their opinion on the company. The indication of all determinants and the perception of them as important confirm previous assumptions that reputation is complex, elusive and extremely difficult to capture in a specific management framework.

Family business managers attempt to solicit the interests of stakeholders in different ways. They communicate with them directly and indirectly through training, media activity, conferences or sponsorship. In order to prevent the loss of reputation, they take action in accordance with the values previously indicated, namely care for customer satisfaction, adherence to ethical principles and transparency in action and conflict solution. The fact that the characteristics of the company studied do not significantly differentiate the opinions on reputation, and even that there are no significant differences in the views of owners, successors and managers of the company, reinforces, in a sense, the truthfulness, relevance and importance of reputation components. It gives rise to recognizing them as important and treating them as the foundation of the reputation management model.

A strategy is an inseparable foundation for management; thus, it can be assumed that reputation management is also based on strategy. Research results did not confirm this assumption; most of the companies surveyed do not have a strategy pertaining to this issue. However, if we define a strategy as an organization's response to its environment, which is an acceptable procedure included in the textbooks, each organization has a strategy, even if it has never been clearly formulated. Additionally, a great number of family businesses have elements of a reputation management strategy embedded in the organization's overall strategy.

In addition to building reputation, managers of a family business must be aware of the dangers of losing their reputation. In their opinion, any element that creates reputation that is neglected or underestimated gives rise to uncertainty and a sense of danger. A poor assessment of the impact of the local environment on the level of reputation is not confirmed in the anticipation of risks. According to the respondents, the risk of the loss of reputation most often involves social responsibility towards the expectations of local communities or NGOs.

The awareness of the importance of reputation in family businesses is confirmed by the estimation of its share in the market value of the companies. Nearly half of all categories of the companies surveyed assess 


\section{Family Business Reputation Management}

the importance of reputation at the level of $40-50 \%$ of the company value, while the companies that are longer on the market and better assess their financial condition rate the contribution of reputation to company value as higher than others. The same is true of the ownership structure: the higher the percentage in the hands of the owner, the greater the importance of reputation. The question, therefore, arises as to whether the importance of reputation in family businesses translates into specific benefits. The answer is clear: in all categories of family businesses, a high share (over $70 \%$ ) in the growth of sales and reduction of the broadly defined marketing activity is attributed to reputation.

At the same time, it can be concluded that the sustainability of reputation is emphasized in family businesses. Thus, through management based on the same unchanging and universal values, these entities will be able to count on attracting the best and the most talented employees, increasing the profitability of the company, increasing engagement, loyalty and identification of employees with the company, spreading ethical behaviour, increasing efficiency and implementing other management practices, which will result in long-term success in these organizations.

\section{Notes}

1 In the cluster analysis method, it is necessary to determine how to measure the distance between objects in the multidimensional space of characteristics and the way of combining objects into a cluster. The distance is usually measured by Euclidean distance, Euclidean squared distance or Manhattan distance. The most common method, which gives the most effective results of cluster assignments, is Ward's method, which is based on the assumption of variance analysis, which states that the variable variance consists of two components: intergroup variance and intragroup variance. In Ward's method, intragroup variance (equivalent to a high object similarity approach) should be minimized and the intergroup variance maximized (which is equivalent to the approach of a small cluster similarity). The result of cluster analysis is a hierarchical tree called a dendrogram, which illustrates the final results of clustering.

2 Principal component analysis (PCA) is popularly used in practice, mainly because it does not require that the assumption of distribution normality for input variables is met (which in practice is virtually impossible, especially for data on weaker measurement scales).

3 Factor loadings created as a result of the analysis show how closely a given input variable is correlated with a given factor. Factor loadings have exactly the same interpretation as a correlation coefficient. Since factor analysis requires that a variable explains a factor as well as possible, high values of these correlations are expected. The analysis also evaluates the correlation matrix between input variables. Two measures are used: KMO and Bartlett's test of sphericity. The first measure shows whether the sample is suitable for factor analysis. The minimum value of the KMO measure is assumed as 0.7. Bartlett's test of sphericity evaluates the singularity of the correlation matrix between variables. It is expected that the singularity hypothesis will be rejected in favour of the opposite hypothesis that the matrix is not singular. If the 
correlation matrix between variables is not singular, it can be expected that there is a hidden factor structure over the analyzed data set.

4 Unless otherwise stated, the differences between the groups of the respondents are statistically significant at the level of confidence of 0.95 .

\section{References}

Kaczmarczyk, S. (2003). Badania marketingowe. Metody i techniki [Marketing research. Methods and techniques]. Warszawa: Polskie Wydawnictwo Ekonomiczne.

Kędzior, Z. and Karcz, K. (2007). Badania marketingowe w praktyce [Marketing research in practice]. Warszawa: Polskie Wydawnictwo Ekonomiczne. 


\section{Evaluation, Conclusions and Recommendations for Family Business Reputation management}

\subsection{Assessment of Family Business Reputation Management}

\section{The Importance of Family Business Value for Reputation Management}

A broad review of the literature allows for the assumption that the distinguishing feature of family businesses and the starting point for family business reputation management are its values. As already established in earlier parts of the work, it is values and corporate culture rather than structural features that distinguish family businesses from non-family businesses. There is a consensus among researchers and practitioners that values in family businesses are closely related to different areas of the company's operation; they are a "background" for organizational culture, they determine strategic planning, goal setting and the model of business management, determine the way of making decisions, implementing strategies, strategic alliances, inspire the development and the achievement of best results and are part of the recruitment and retention of employees.

It was assumed that the company is oriented towards stakeholders if it defines and ranks their groups, taking the real impact on the company's functioning and performance into account, and is aware of their expectations. It was also assumed that family business values have a positive impact on the company's focus on stakeholders, are shared with the stakeholders (Table 5.1), and thus affect the knowledge of factors which determine reputation (Table 5.2 and 5.3) and have a positive impact on communication with the environment.

The results of Spearman's rank correlation analysis indicate that there are positive correlations in the assumed areas. In the opinions of the respondents who indicated the most important stakeholders from their perspective, a statistically significant relationship was observed:

1. in the group of customers for values such as family reputation, trust, responsibility and integrity towards stakeholders;

DOI: $10.4324 / 9781003226215-5$ 


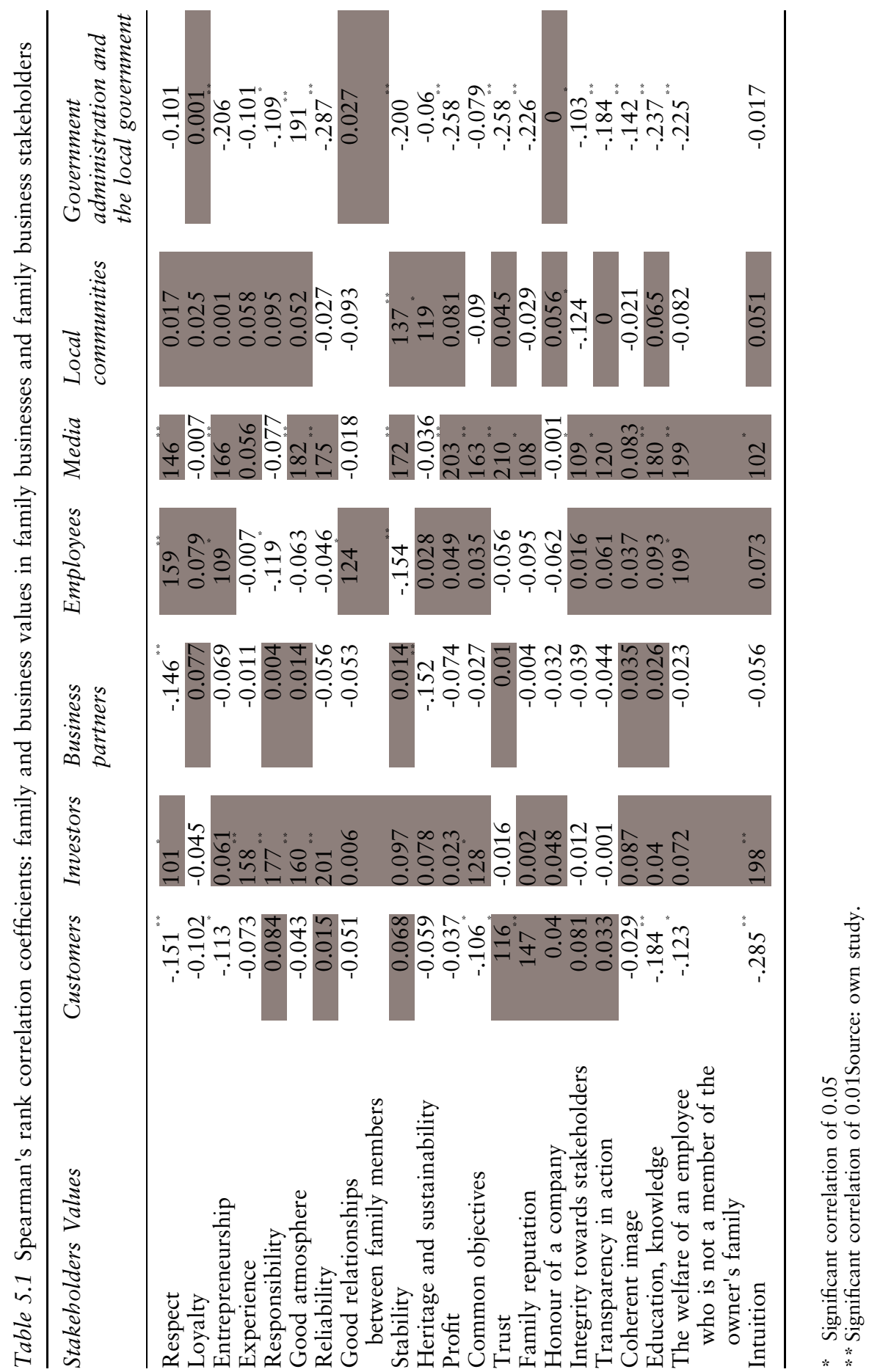




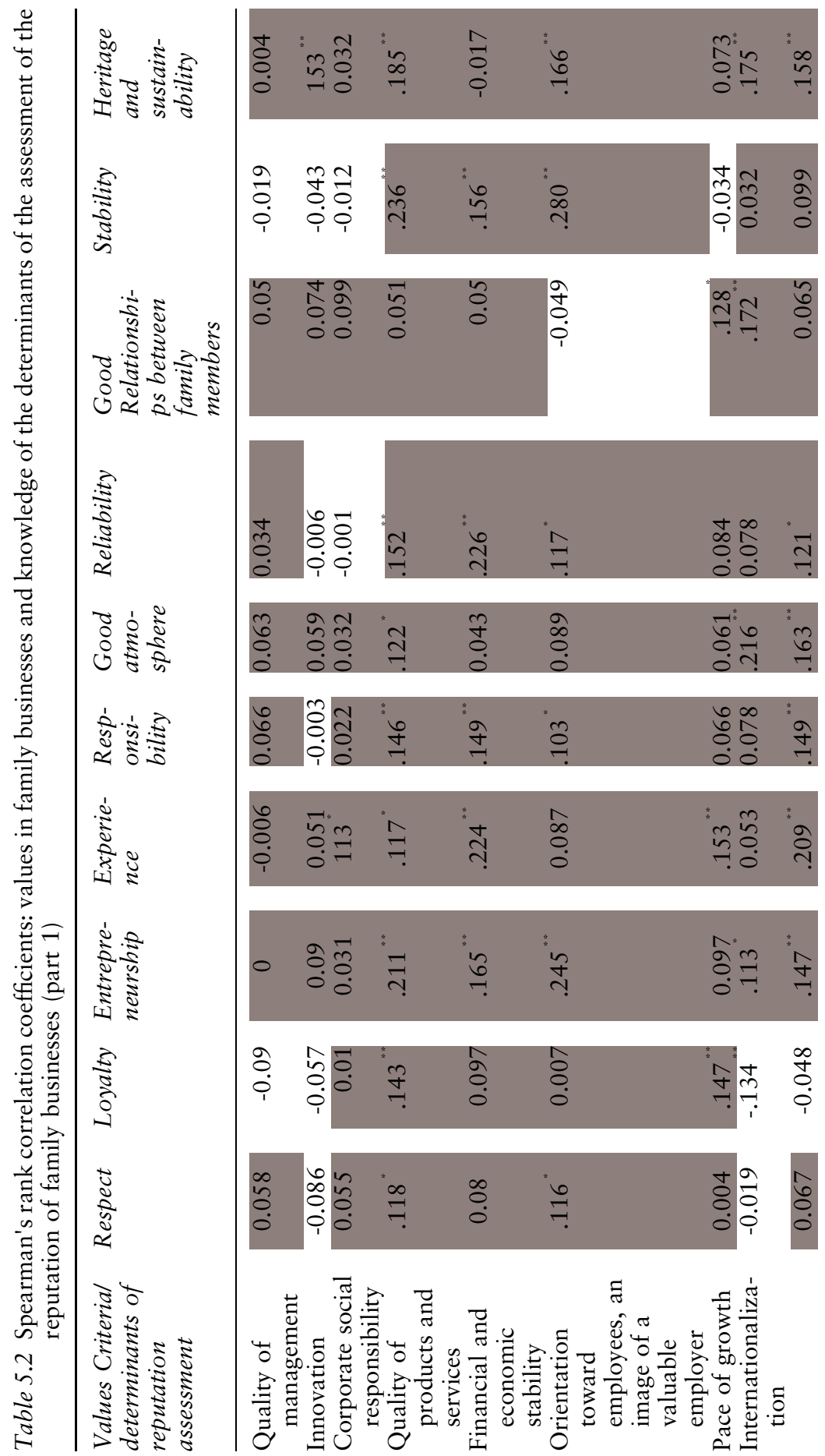



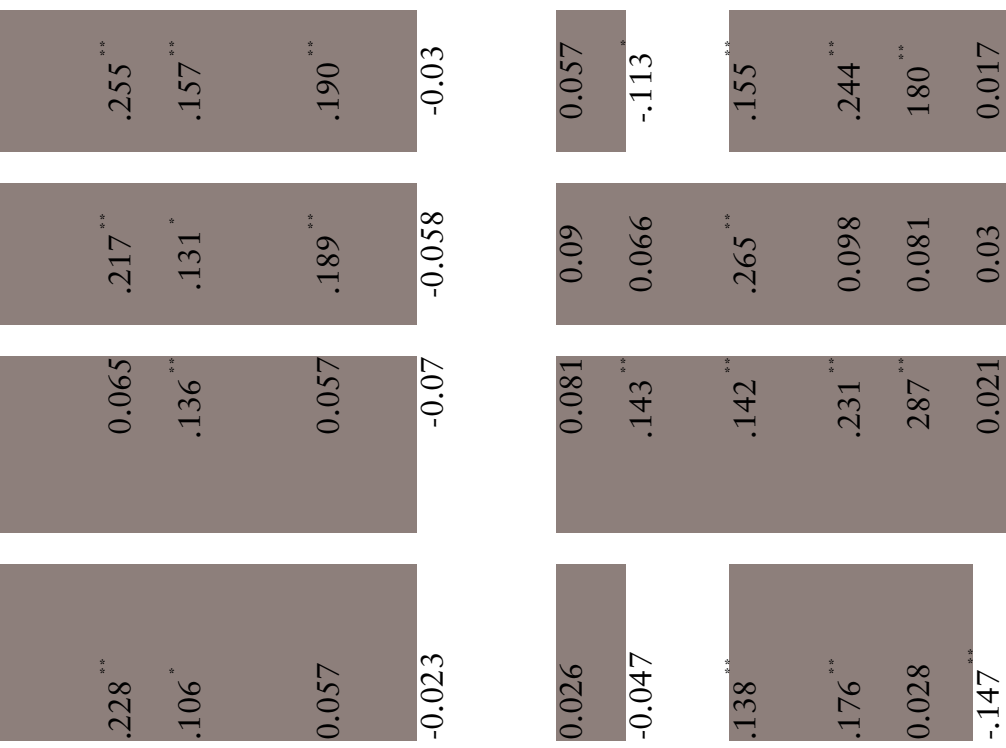

구

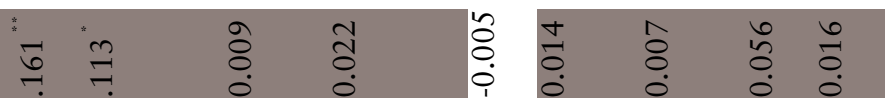

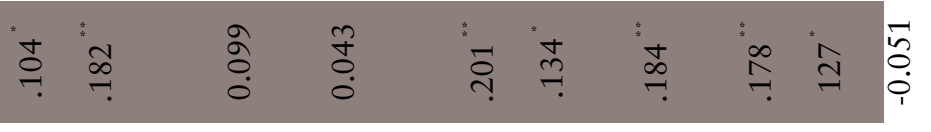

" * * "

\begin{tabular}{|c|c|c|c|c|c|c|c|c|}
\hline$\underset{F}{ }$ & $\hat{0}$ & m & $\frac{\infty}{0}$ & $\frac{a}{\dot{0}}$ & 官 & $\stackrel{+}{\sim}$ & 6 & $\begin{array}{l}\infty \\
0 \\
0\end{array}$ \\
\hline
\end{tabular}

\section{๖ั}

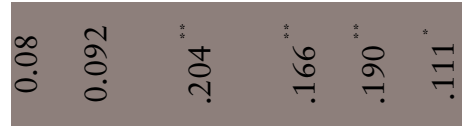

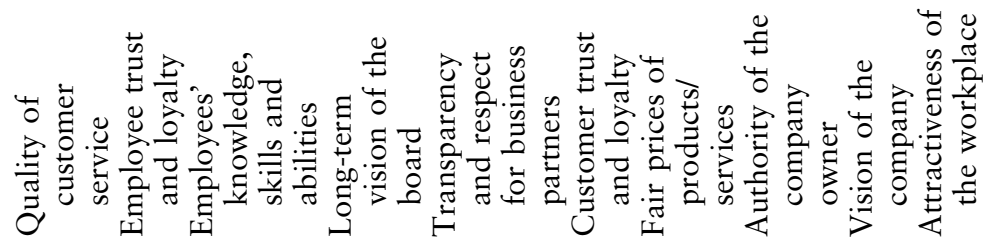




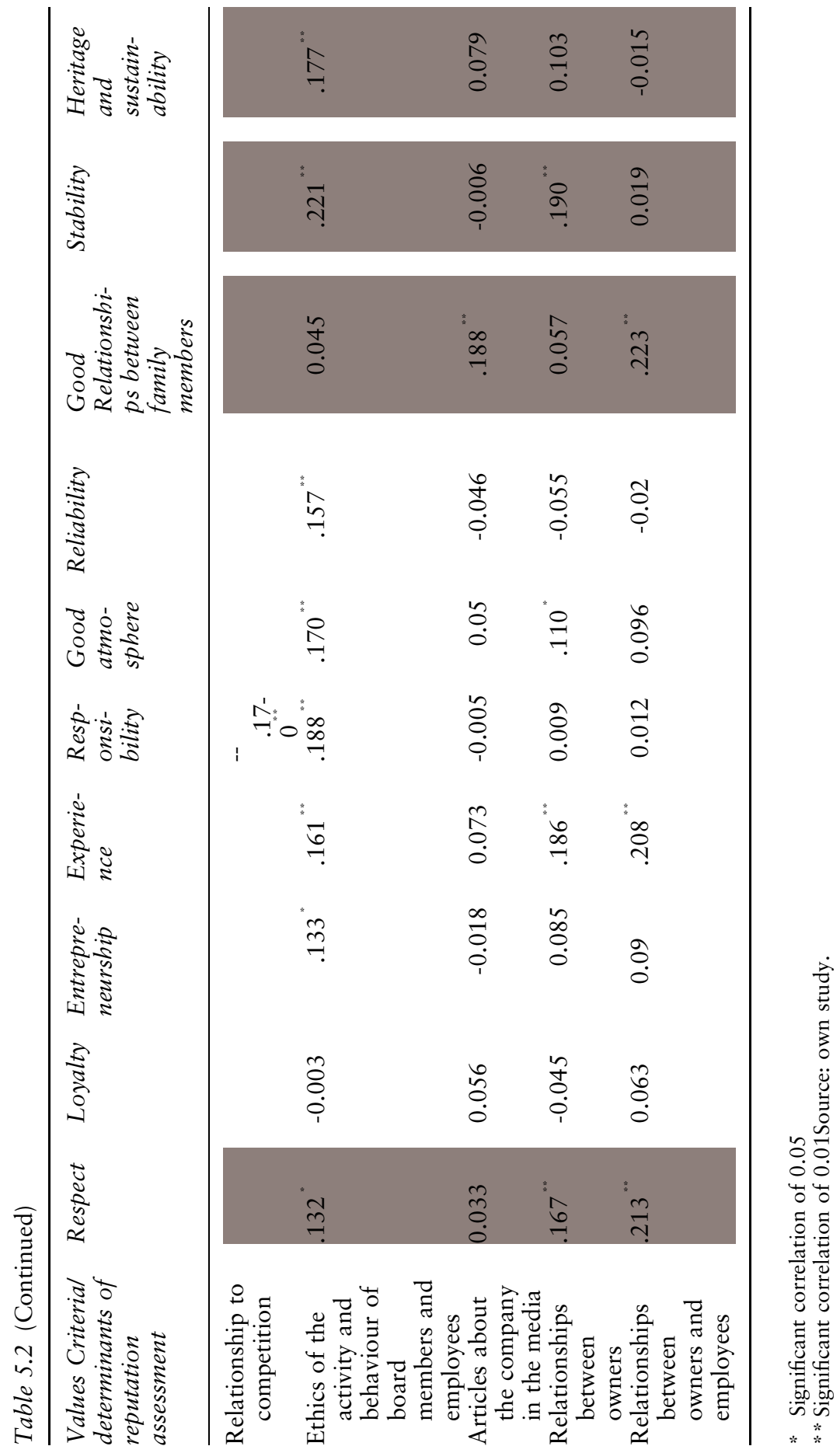




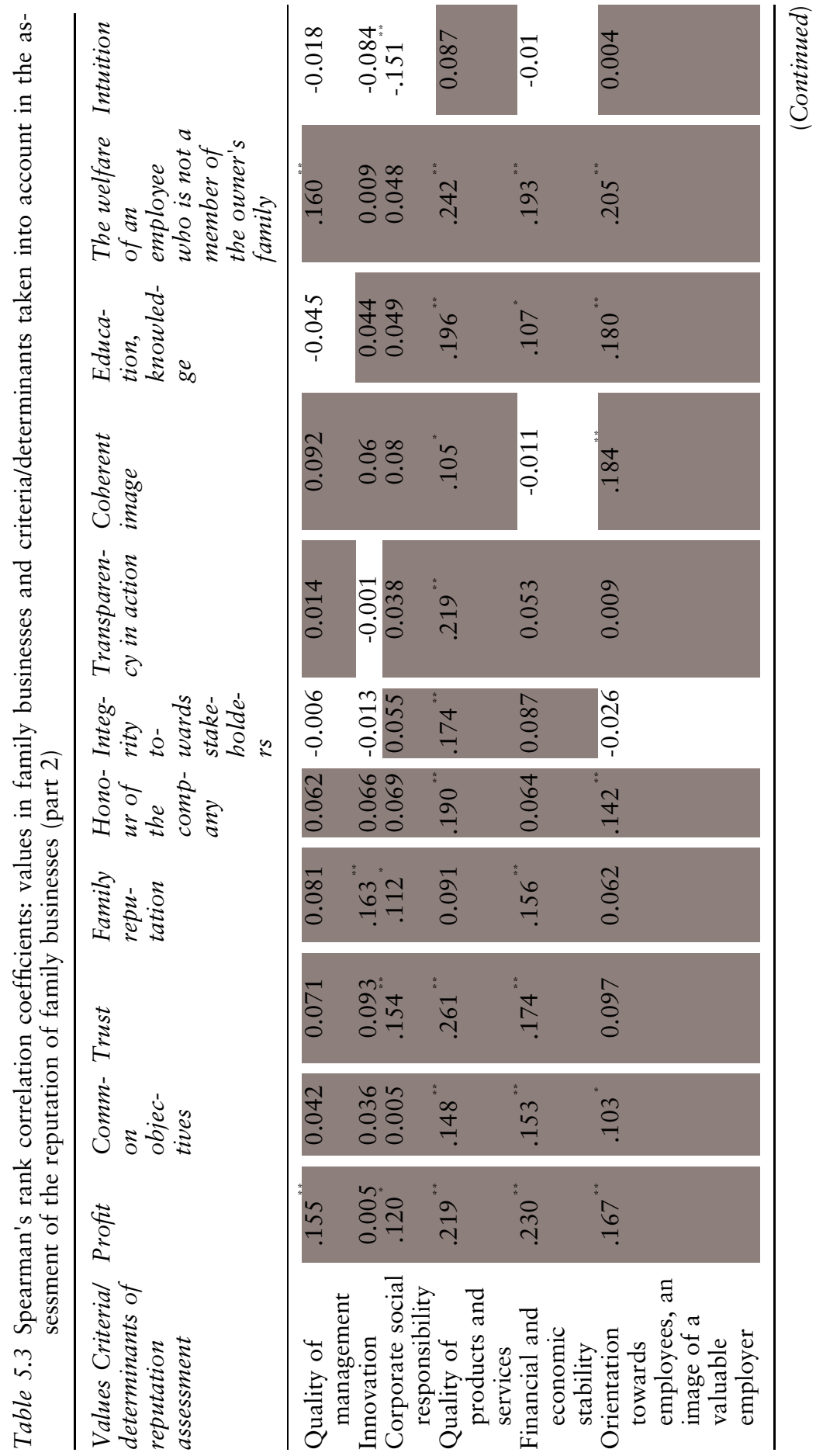




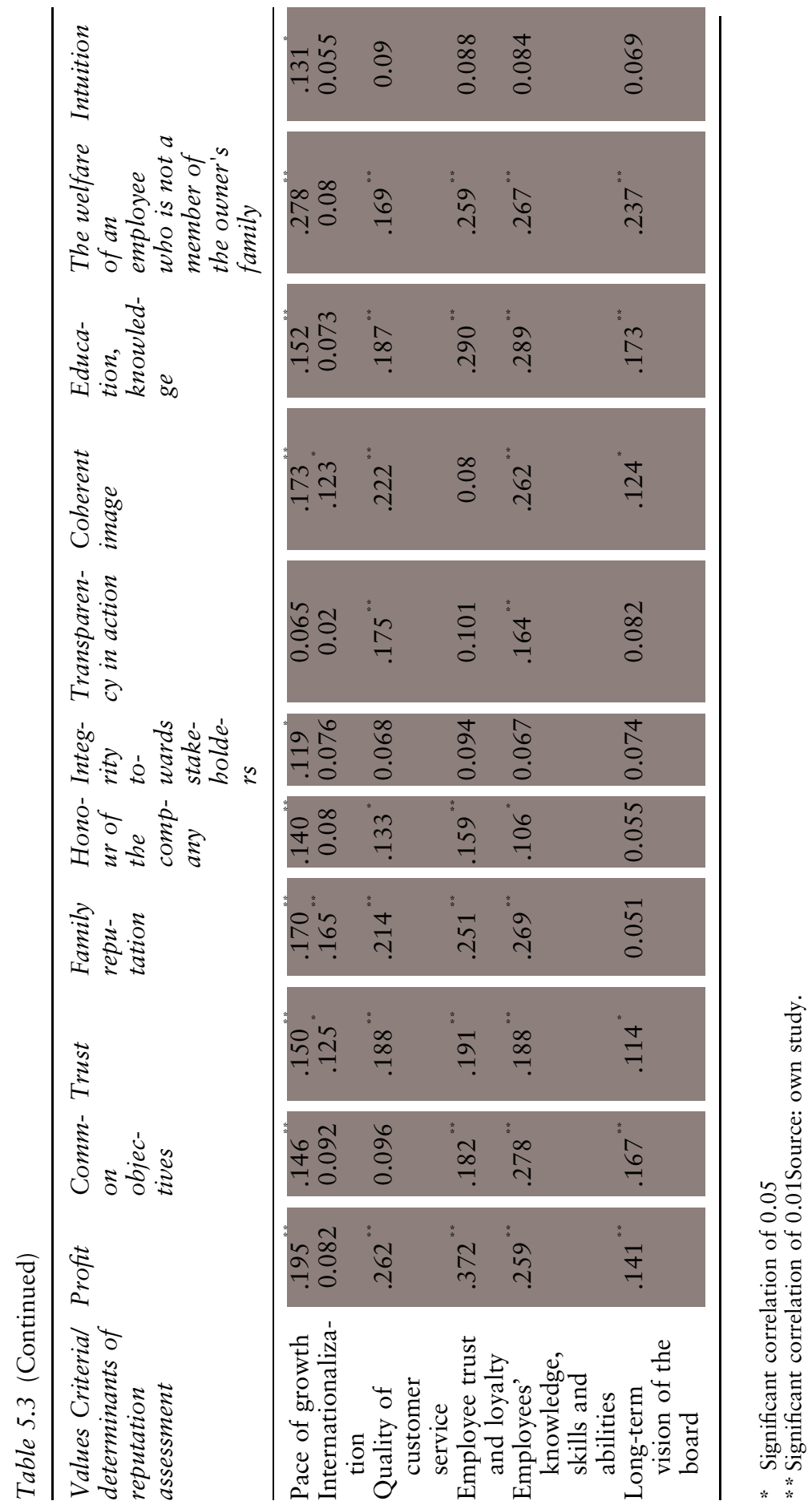


2. in the group of investors for values such as reliability, intuition, responsibility, a good atmosphere and experience;

3 . in the group of employees: respect, good relationships between family members and the welfare of an employee who is not a member of the owner's family;

4. the media: trust, profit, well-being of an employee who is not a member of the owner's family, good atmosphere, education and knowledge;

5. business partners: respect;

6. local communities: stability.

In the case of the correlation of values with a group of customers, business partners, employees and government and local government, negative correlations prevail.

The results of further analysis of the correlation between family and business values and knowledge of stakeholders' expectations are presented in Tables 5.2 and 5.3.

The results of Spearman's rank correlation analysis show that there are positive correlations between values which are important for family businesses and areas of the assessment of the reputation of family businesses (stakeholder expectations). The results show that the relationships between defined areas are positive.

The most important values for the respondents included common goals, integrity towards stakeholders, profit, reliability and responsibility. If the company is committed to achieving common goals, it will appreciate the knowledge, skills and abilities of employees; if the value is profit, it will be related to employee trust and loyalty, the quality of customer service, including the appropriate response to errors occurring, and the authority of the business owner; reliability is related to the trust and loyalty of employees, and responsibility to the ethics of the activities conducted and the ethics of the behaviour of board members and employees. Good relationships between family members are associated with the vision of the company and the attractiveness of the workplace; and respect is linked with the long-term vision of the management board. If the value of the company is trust - customer trust and loyalty are important, as are the relationships between owners, their business ethics and the ethics of the behaviour of board members and employees. There was also a relationship between the authority of the company owner and values such as stability, profit and respect. Financial and economic stability is strongly correlated with profit, reliability and experience. In addition, there is a relationship between employees' knowledge, abilities and skills and family and business values such as entrepreneurship and profit.

It can be concluded that there is a positive relationship between family business values and the company's stakeholder orientation. 


\section{Evaluation, Conclusions \& Recommendations}

Furthermore, it is assumed that there is a relationship between the company values and the knowledge of factors that affect its reputation. This area is expressed by the way of defining reputation (Table 5.4) and the knowledge of the factors that affect the reputation of the family business.

The results in Table 5.4 show that the vast majority of relationships are positive. Among the options for defining the essence of reputation, a response which identified reputation as "a way in which the company is perceived and evaluated by stakeholders capable of attracting loyal customers" was most often indicated. This term shows a connection with values such as a coherent image, education and knowledge, family reputation and trust. The strongest correlation was observed for the following statement: "reputation is a form of market value of a company, the amount of which be subject to changes in time depending on the assessment of the company's activities" and the value of heritage and sustainability, as well as the relationship with the family's reputation and the honour of a company. There is also a correlation between values such as a coherent image, education, knowledge and a family's reputation for understanding corporate reputation as a way of perceiving and evaluating a company by stakeholders which can attract loyal customers. The definition of reputation as an intangible asset is influenced by the following family and business values: the honour of a company and a coherent image. Furthermore, it was observed that a value such as profit affects the definition of reputation as barriers to market entry.

It was also assumed that there is a relationship between the values of a company and the characteristics of the company, which can strengthen reputation (Table 5.5). The data in Table 5.5 show that the strongest relationship was observed for the following features: the quality of customer service, including an appropriate response to emerging errors, and values such as profit. There is also a relationship between this feature and values such as experience, trust, care for the welfare of an employee who is not a member of the owner's family, and family reputation. There is a relationship between employees and owners that influences the atmosphere at work and values such as profit, trust and family reputation. The uniqueness of the products and services offered, as well as the difficulty competitors have to copy them, is correlated with heritage and sustainability, a good atmosphere and profit. There is also a correlation between profit and the following factors which affect reputation: relationships between employees and owners, which affect the atmosphere at work, the business strategy understood by stakeholders, and values characteristic of the family business. Moreover, a correlation between heritage and sustainability and factors such as the uniqueness of the products and services offered, the difficulty which competitors have to copy them, and a business strategy understood by stakeholders have been identified. 


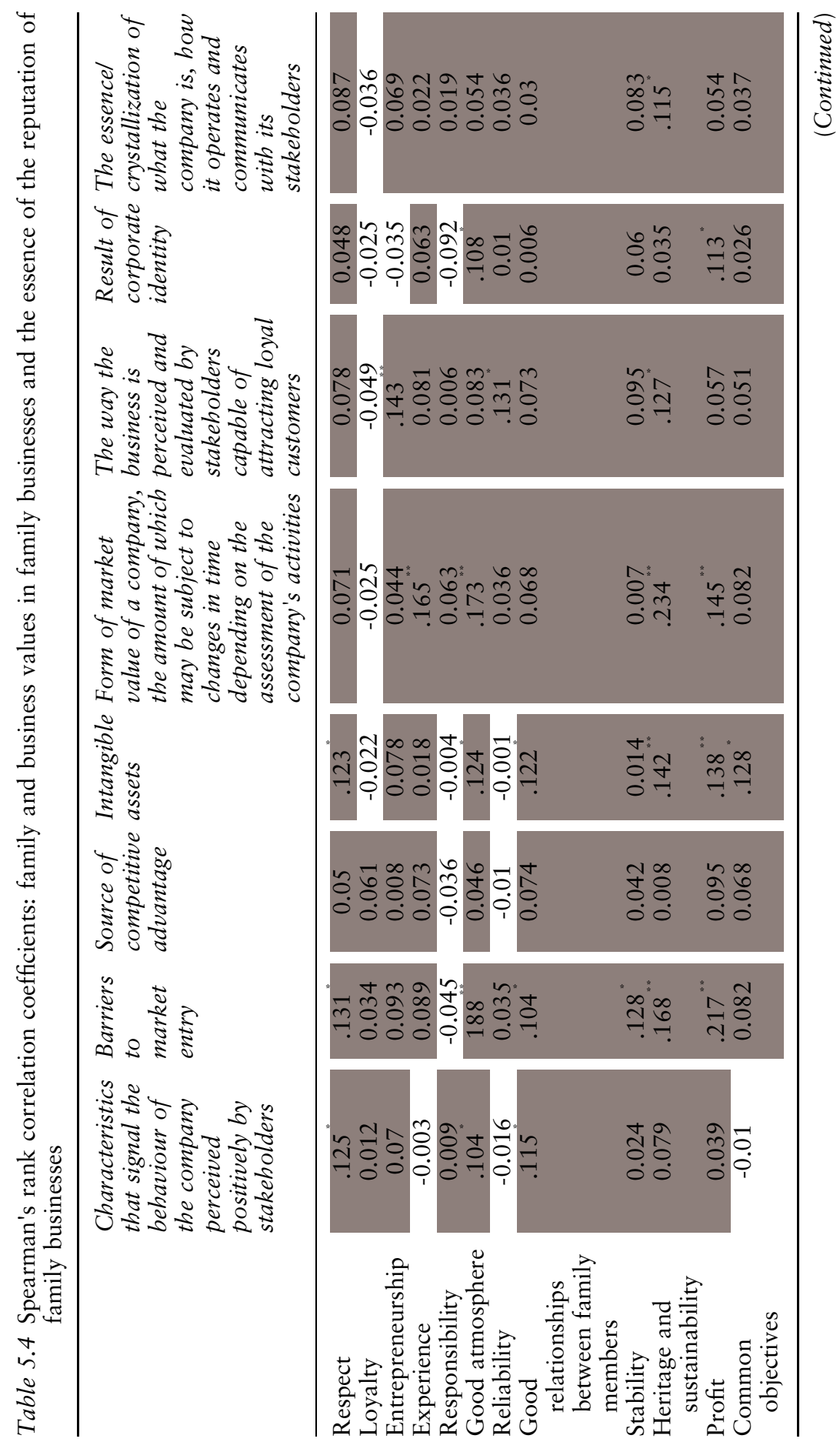




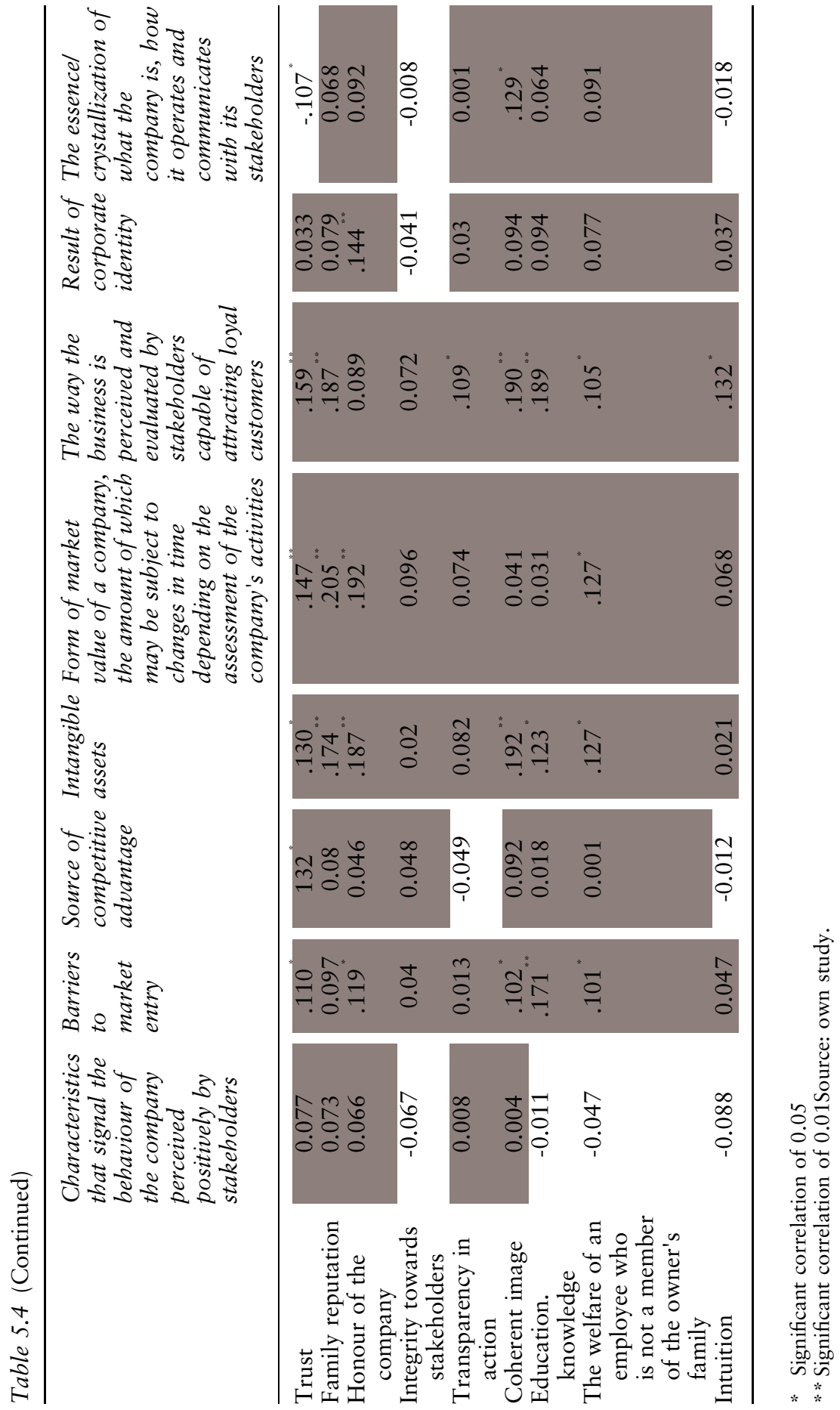




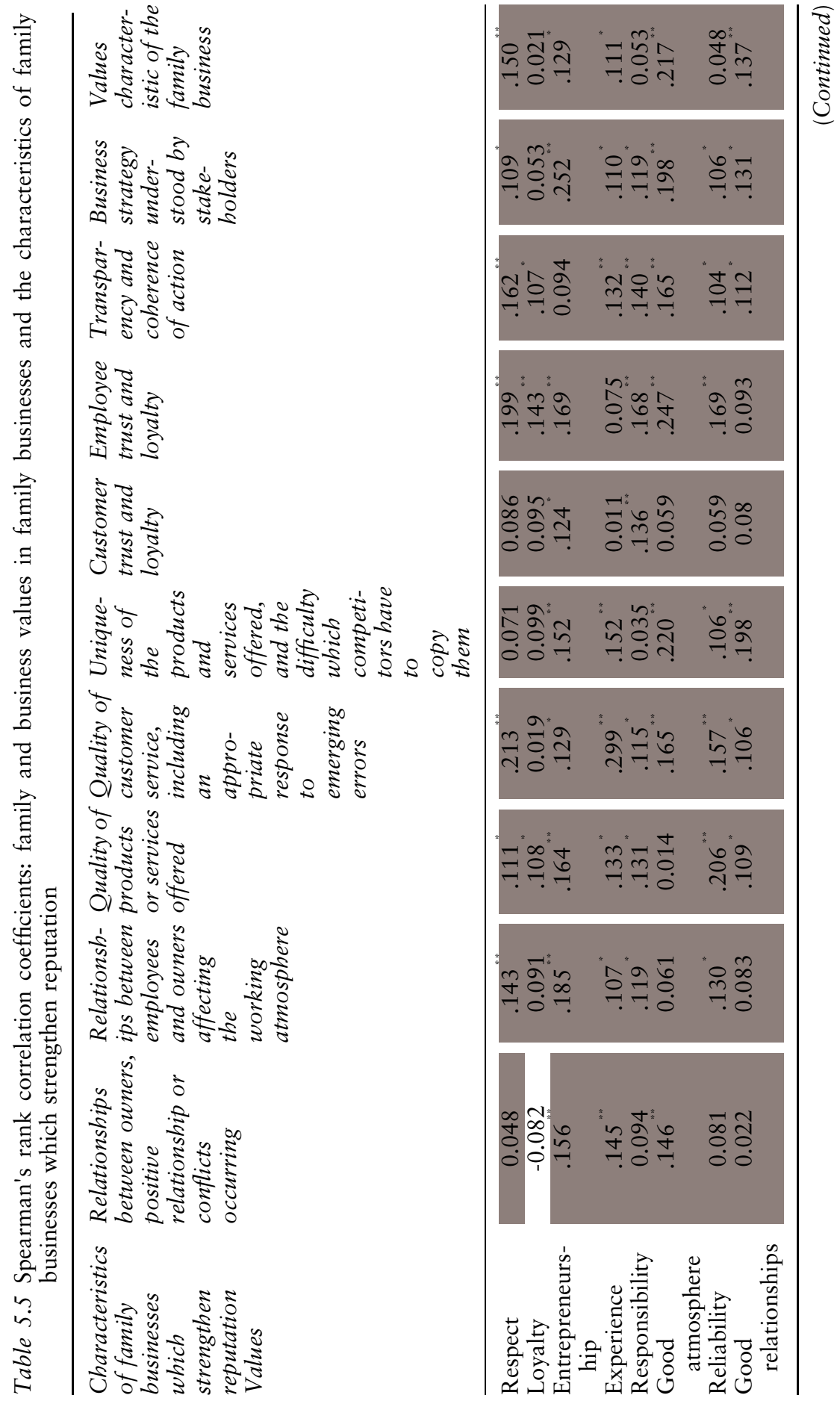




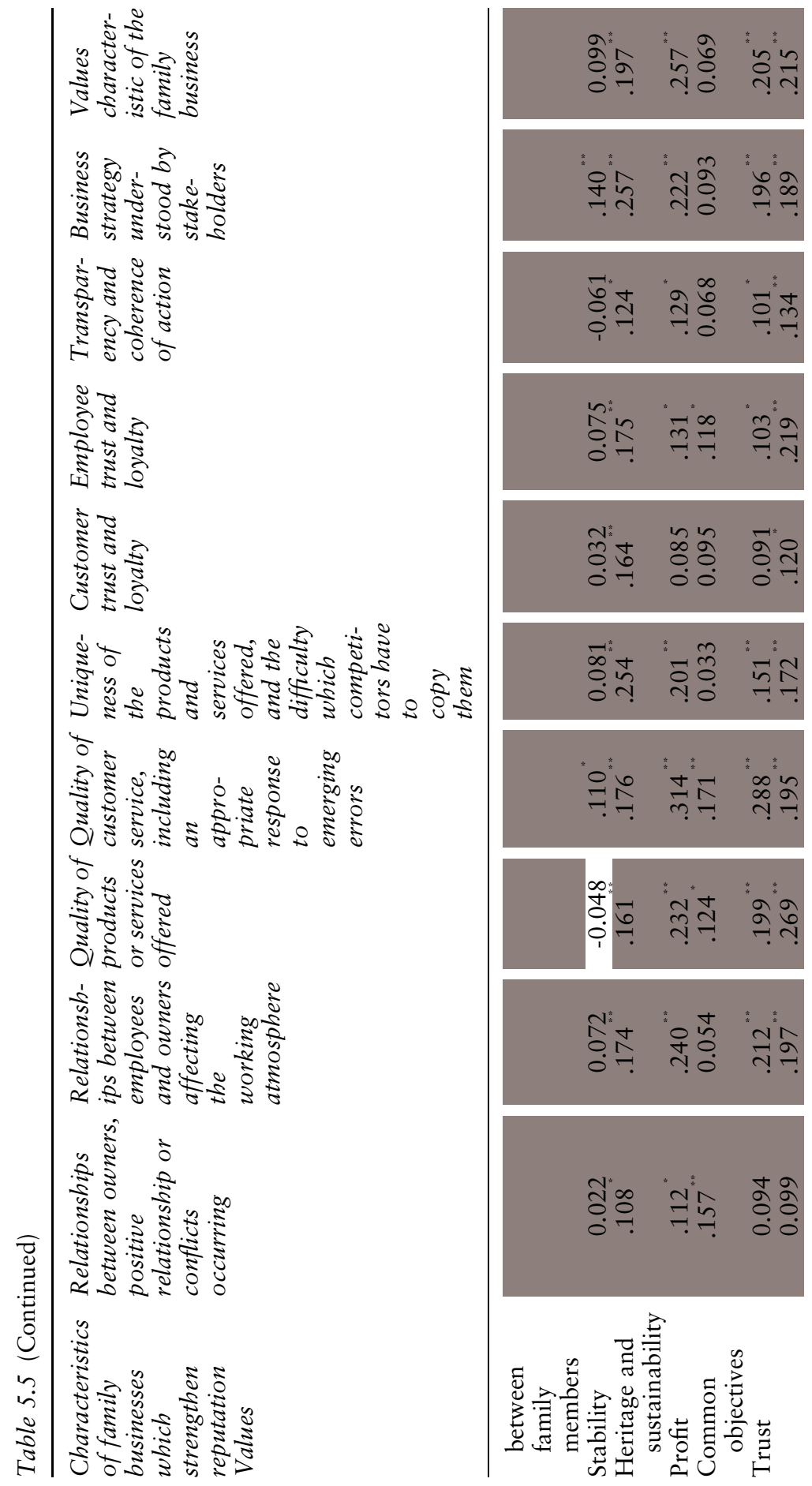



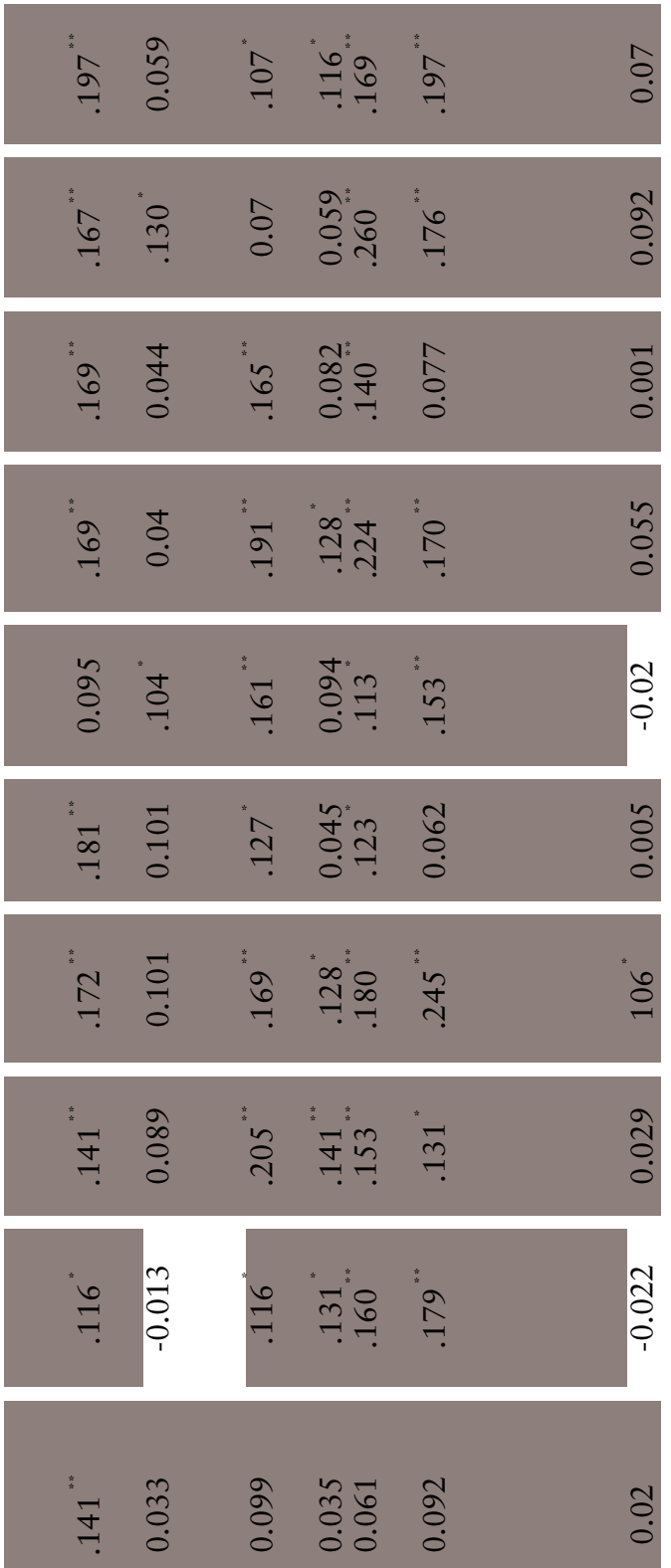

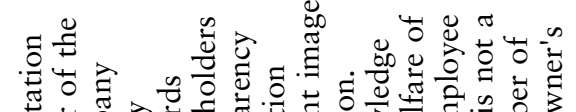

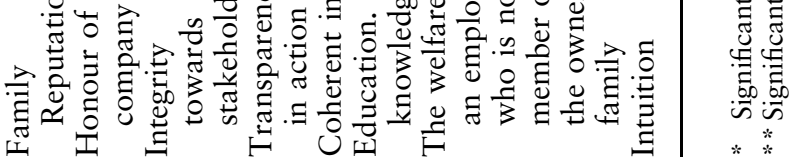




\section{Evaluation, Conclusions \& Recommendations}

Table 5.6 Determinants of the value of reputation (Spearman's rank correlation coefficients)

Spearman's rank correlation coefficients: Percentage of goodwill which is attributable to reputation

How to define reputation and value of reputation

Characteristics that signal the behaviour of the company perceived 0.043 positively by stakeholders

Barriers to market entry

Source of competitive advantage

.143

Intangible assets

Form of market value of a company, the amount of which may be subject to changes in time depending on the assessment of the company's activities

The way the company is perceived and evaluated by stakeholders capable of attracting loyal customers

Result of corporate identity

The essence/crystallization of what a company is, how it operates and how it communicates with its stakeholders

Knowledge of the factors affecting the reputation of the family business which strengthen it and value of reputation

Relationships between owners, positive relationships or conflicts 0.059 occurring

Relationships between employees and owners affecting the 0.068 working atmosphere

Quality of products or services offered

Quality of customer service, including an appropriate response to emerging errors

Uniqueness of the products and services offered, and the difficulty which competitors have to copy them

Customer trust and loyalty

$-0.015$

Employee trust and loyalty

0,036

Transparency and coherence of action

Business strategy understood by stakeholders

.192

Values characteristic of the family business

.162

Knowledge of the key company stakeholders and the value of reputation

Customers

.340

Investors

0.042

Business partners

$-0.08$

Employees

$-.226$

The media

0.019

Local communities

$-0.023$

Government and local government administration

$-0.049$

Knowledge of stakeholder expectations and their criteria for assessing reputation and the value of the reputation of the family business

Quality of management

.152

Innovation

Corporate social responsibility

0,085

Quality of products and services

.144

$.199^{*}$

Financial and economic stability

.115

Orientation toward employees, image of a valuable employer 
Table 5.6 (Continued)

Spearman's rank correlation coefficients: Percentage of goodwill which is attributable to reputation

Pace of growth .120

Internationalization 0.067

Quality of customer service, including an appropriate .105 response to emerging errors

Employee trust and loyalty 0.07

Employees' knowledge, skills and abilities

Long-term vision of the board $-0.03$

Transparency and respect for business partners

0.06

Customer trust and loyalty .217

$\begin{array}{ll}\text { Fair prices of products and services } & 0.077\end{array}$

Authority of the company owner $\quad 0.034$

$\begin{array}{ll}\text { Vision of the company } & 0.079\end{array}$

Attractiveness of the workplace $\quad 0.046$

Relationship to competition

Ethics of the activity and the behaviour of board members and employees

Articles about the company in the media

Relationships between owners

Relationship between owners and employees

* Significant correlation of 0.05

* Significant correlation of 0.01 Source: own study.

The results show that there is usually a positive correlation between the assumed areas. Detailed results are shown in Table 5.5. The results show that the vast majority of relationships are positive. The above analyses show that assumption about the impact of family business values on the company's stakeholder orientation and the knowledge of factors affecting reputation is confirmed.

\section{Factors Affecting Family Business Value}

In the course of the research process, the assumption of determinants of the value of reputation was verified (Table 5.6). It was assumed that this value was influenced by stakeholder orientation and the identification of factors affecting reputation.

Although the assumption seems obvious, it is worth confirming it with empirical data. The way the company managers define and understand the concept of reputation will probably determine their behaviour in terms of building or maintaining a certain level of reputation. If a company does not regard reputation as values and assets, their investment in reputation-enhancing activities will be lower. The results show 
that there are positive correlations between the value of reputation and the assessment levels for terms pertaining to factors affecting reputation. The more the respondent agrees with the term, the greater the percentage of goodwill represented by reputation.

The results in Table 5.6 also show that there are usually positive correlations between the value of reputation and the levels of factors affecting reputation. The higher the factor, the greater the percentage of goodwill represented by reputation. The strongest relationship was observed for the factor of the business strategy as understood by stakeholders and, importantly from the point of view of this work, the presence of values characteristic of the family business. This is confirmed by the assumption that the specificity of family businesses is the foundation for building their reputation. It can be concluded that the assumption pertaining to the impact of stakeholder orientation on the value of corporate reputation is confirmed.

Later, the relationship between the company's stakeholder orientation and the value of reputation was verified. There are various correlations between the value of reputation and the hierarchy of stakeholders. When customers, investors and media are recognized as the most important stakeholders, the higher assessments of the impact strength are associated with a higher proportion of goodwill which is attributable to reputation. This relationship can be interpreted as the importance of individual stakeholder groups to the company and their impact on reputation building. Stakeholders most closely linked to the company (through business profile, market type, industry, market segment, product specificity, owner, company activities and even emotions caused by certain behaviours) offer a stronger response to the company's activities in the form of increased interest, positive feedback on social media, loyalty, more frequent purchases, etc.

The results of the analysis show that there is a positive correlation between the value of reputation and the knowledge of stakeholders' expectations. A positive correlation means that increasing the value of one variable increases the value of the other variable. The highest value of correlation was observed for customer trust and loyalty and the quality of products and services. Given the above, it can be concluded that assumption on the impact of knowledge of factors affecting the value of reputation has been confirmed.

\section{Strategy for Building a Family Business}

A further part of the research was devoted to the verification of the components of reputation-building strategy. It is assumed that the reputation-building strategy is based on the company's stakeholder orientation and the knowledge of factors affecting reputation. The results of the correlation between stakeholder orientation and knowledge of the 


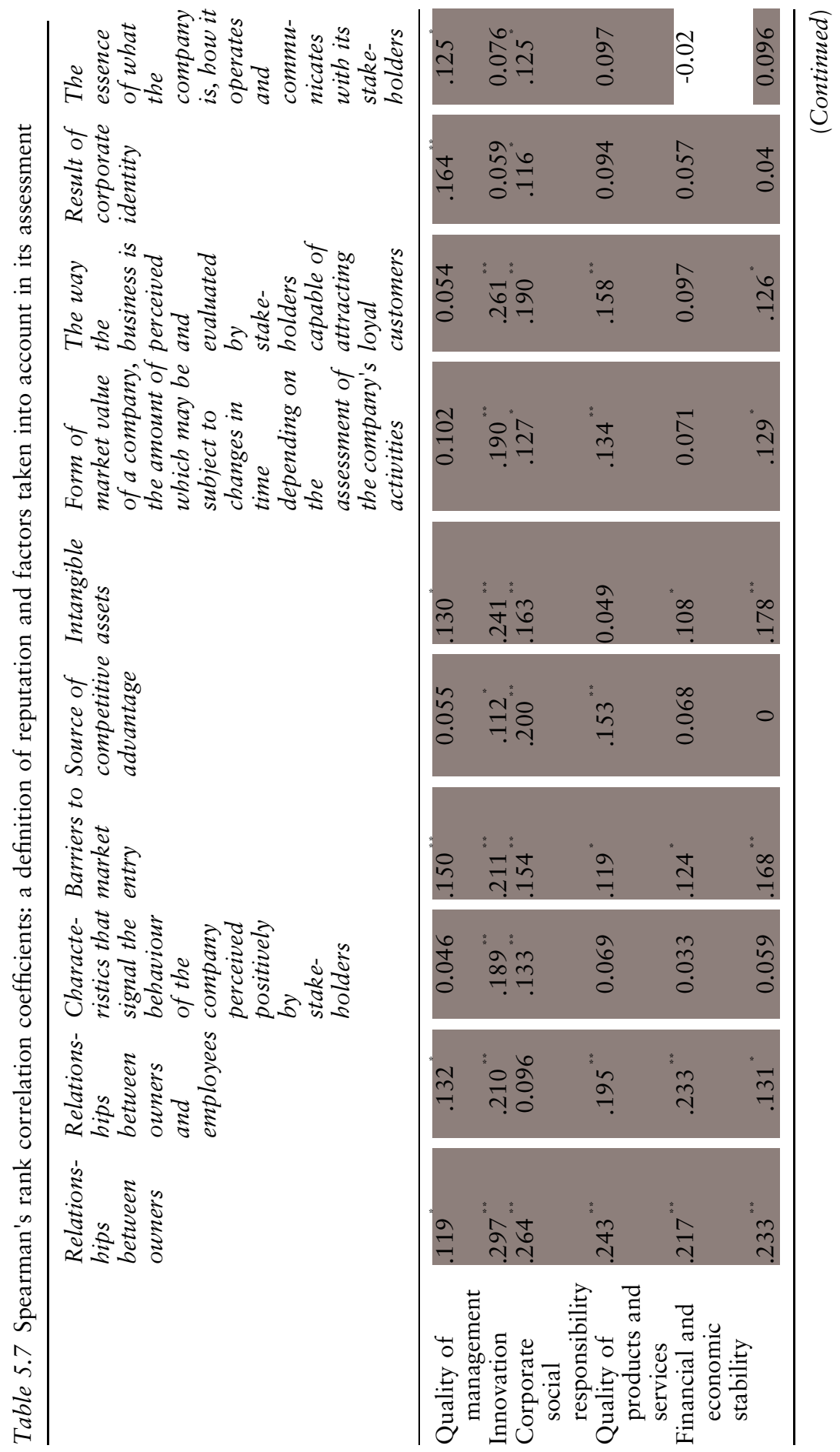


192 Evaluation, Conclusions \& Recommendations

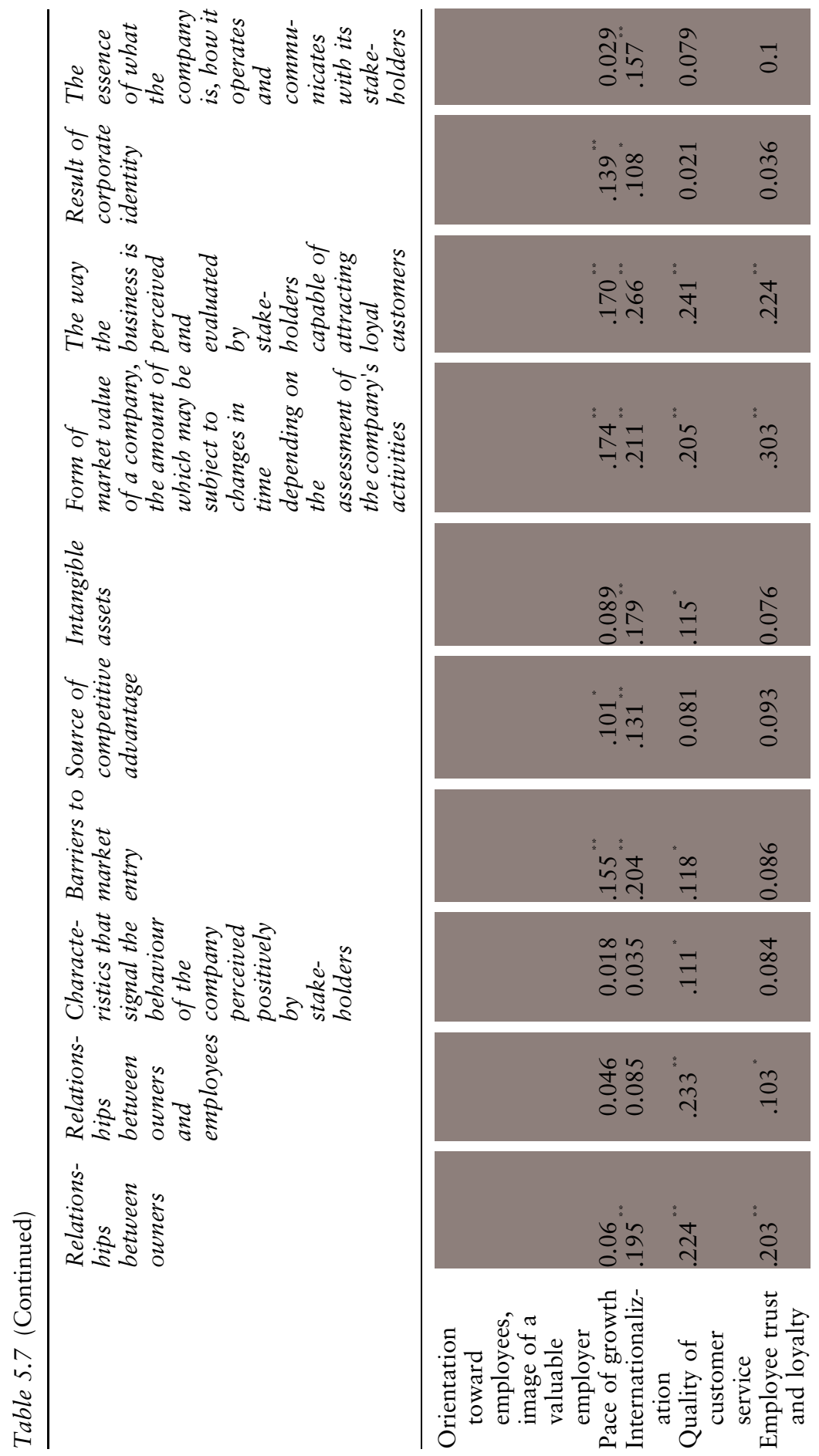




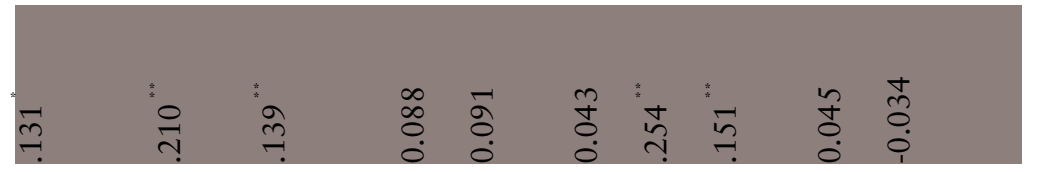

\begin{tabular}{|c|c|c|c|c|c|c|c|c|c|}
\hline $\begin{array}{l}\infty \\
\dot{0} \\
0 \\
0\end{array}$ & $\stackrel{1}{\circ}$ & 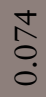 & $\begin{array}{l}\hat{N} \\
\hat{0} \\
\stackrel{0}{0}\end{array}$ & $\begin{array}{l}\mathfrak{n} \\
0 \\
0\end{array}$ & 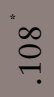 & $\begin{array}{l}\text { Uै } \\
\stackrel{1}{0} \\
\stackrel{0}{0}\end{array}$ & $\begin{array}{l}\infty \\
8 \\
0 \\
0\end{array}$ & $\begin{array}{l}0 \\
0 \\
0\end{array}$ & $\begin{array}{l}+ \\
\infty \\
0 \\
0\end{array}$ \\
\hline
\end{tabular}

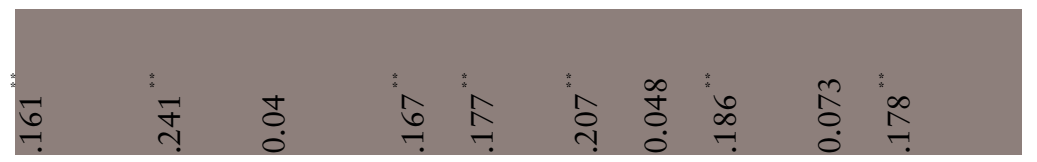

\begin{tabular}{|c|c|c|c|c|c|c|c|c|c|}
\hline $\begin{array}{l}n \\
\hat{0} \\
0\end{array}$ & $\begin{array}{l}m \\
0 \\
0 \\
0\end{array}$ & $\begin{array}{l}\widehat{N} \\
\text { ô. } \\
\text {. }\end{array}$ & F & $\tilde{0}$ & ㄱ. & $\begin{array}{l}6 \\
0 \\
0 \\
0\end{array}$ & $\begin{array}{l}0 \\
\stackrel{0}{0} \\
0\end{array}$ & 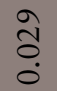 & $\begin{array}{l}2 \\
0 \\
0\end{array}$ \\
\hline
\end{tabular}

\begin{tabular}{|c|c|c|c|c|c|c|c|c|c|}
\hline ণิ & $\begin{array}{l}\infty \\
\text { సิ }\end{array}$ & $\stackrel{n}{\circ}$ & $\stackrel{\infty}{\circ} \underset{?}{?}$ & $\stackrel{\infty}{\stackrel{\infty}{\Upsilon}}$ & $\stackrel{+}{\longrightarrow}$ & ๙ & $\begin{array}{l}\text { I } \\
\text { t. }\end{array}$ & $\stackrel{n}{?}$ & ָָ \\
\hline
\end{tabular}

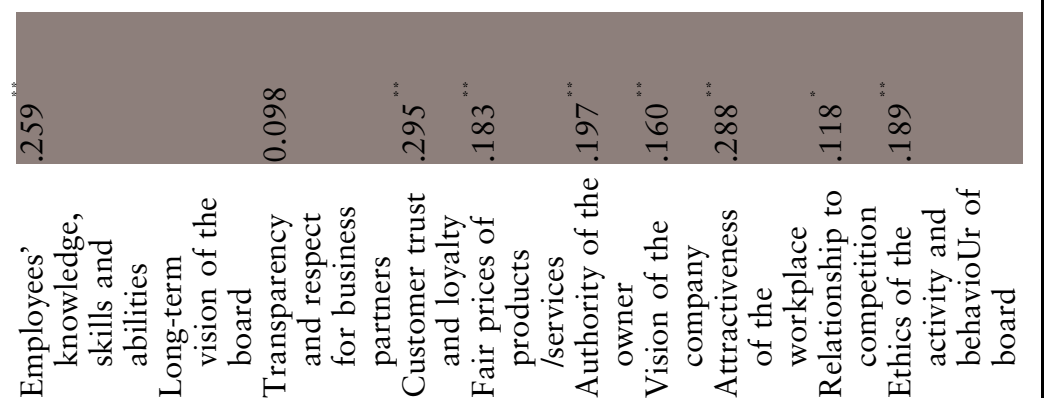




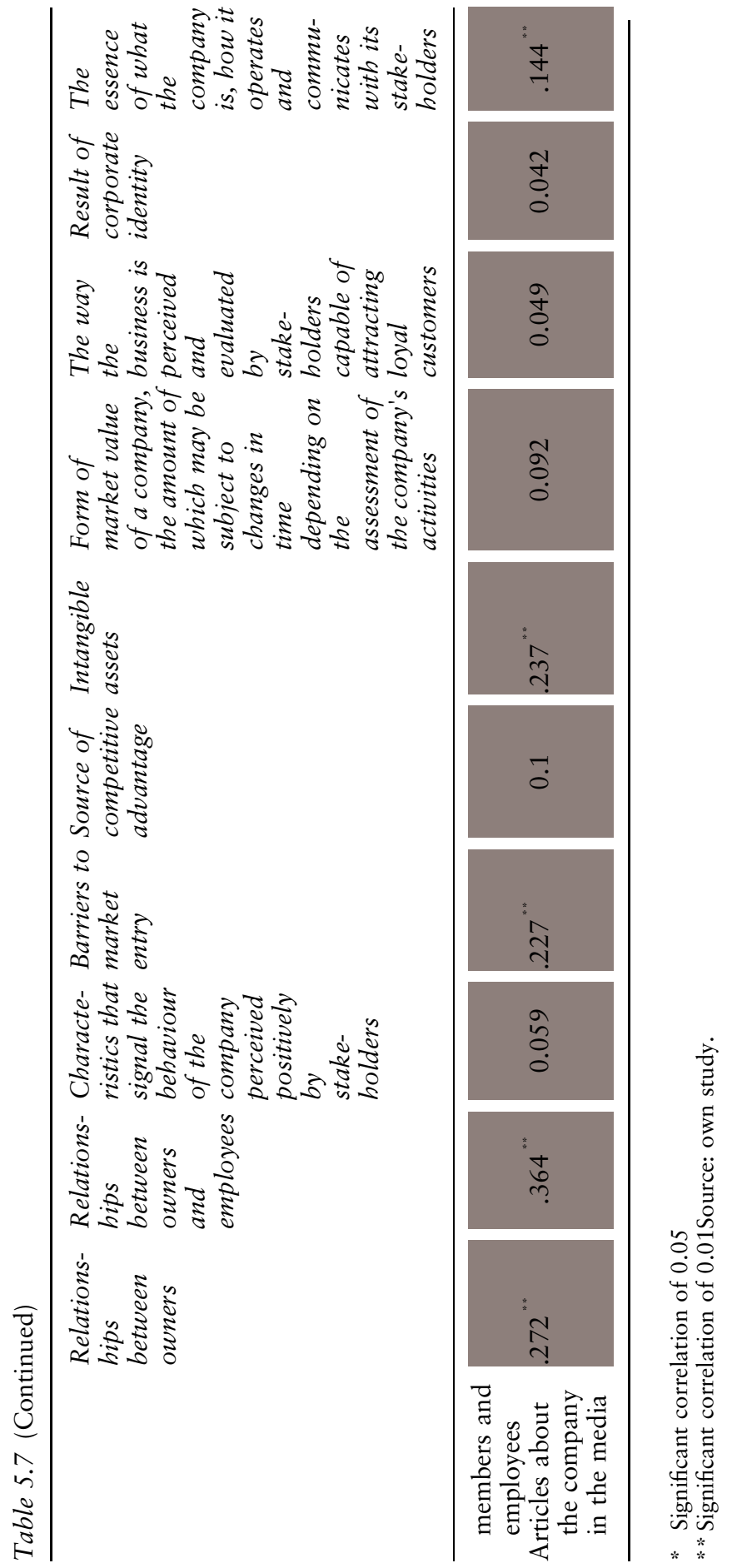




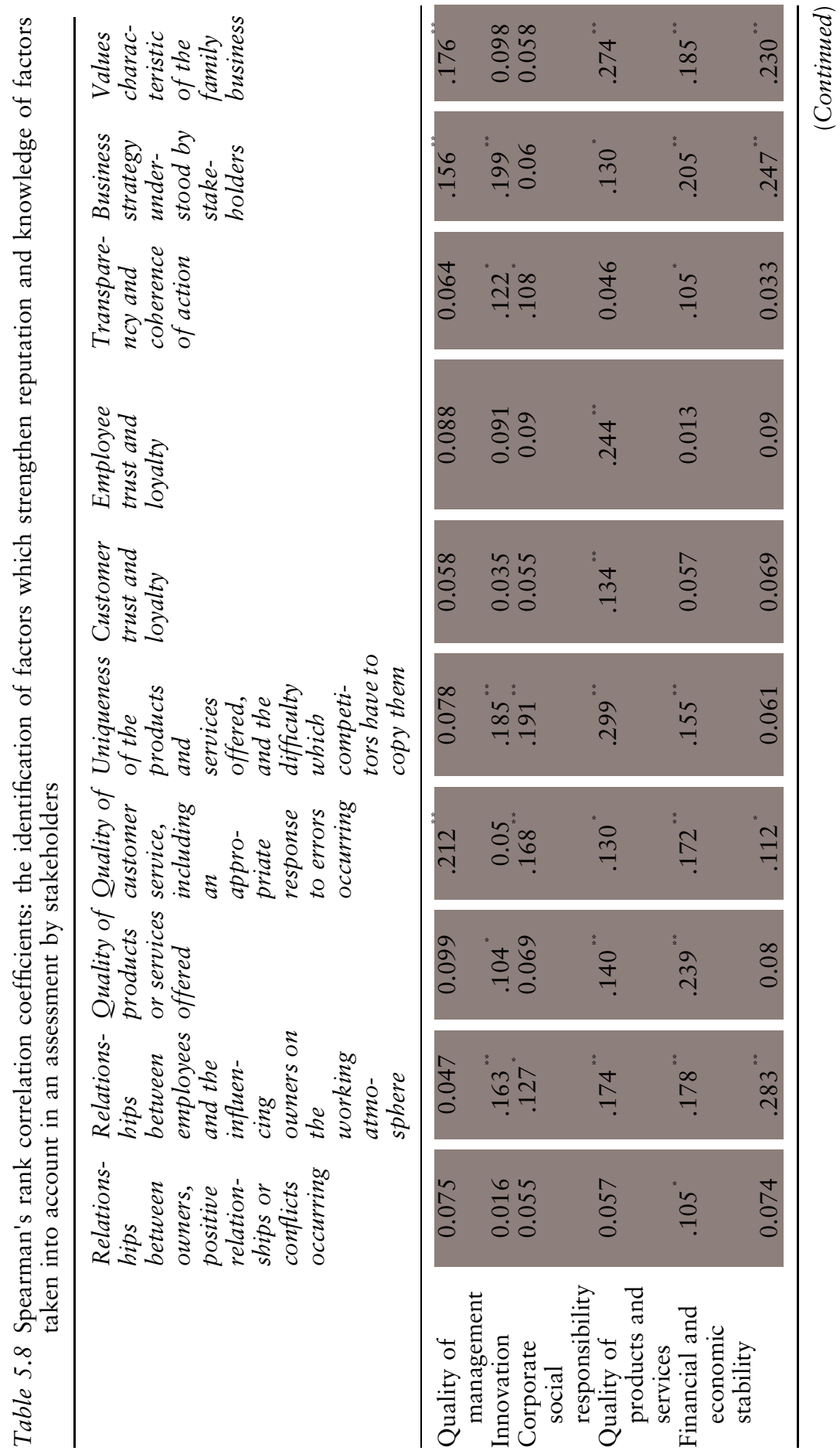




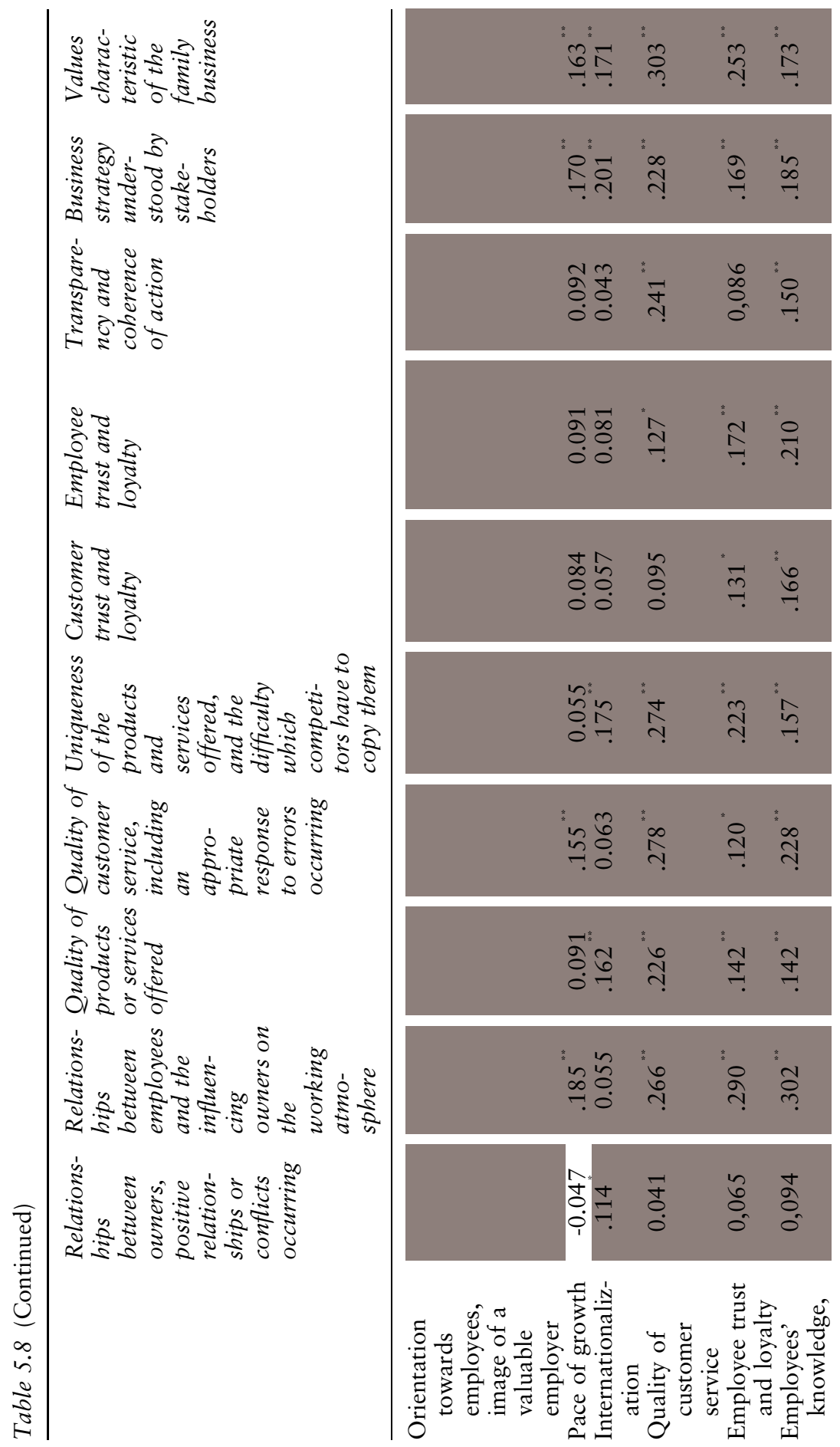




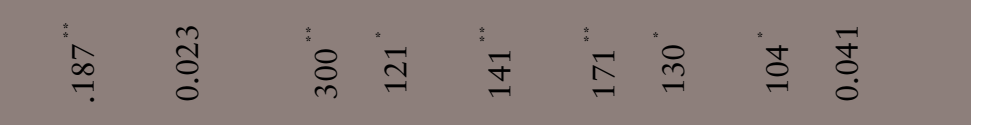

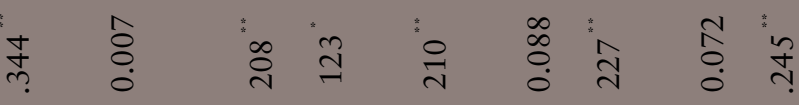

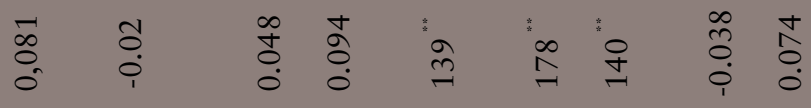

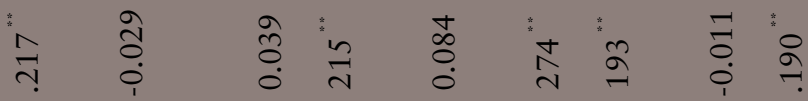

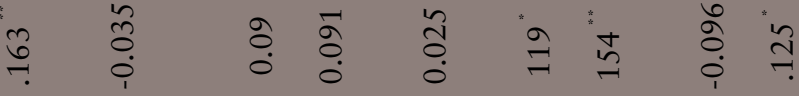

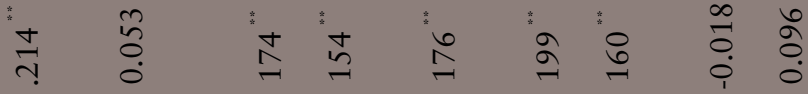

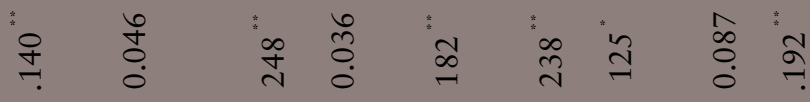

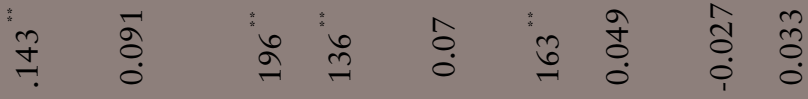

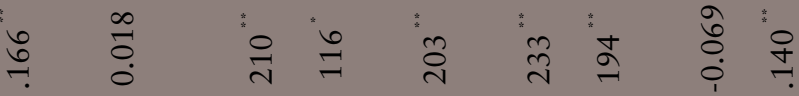

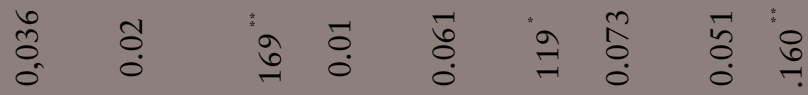

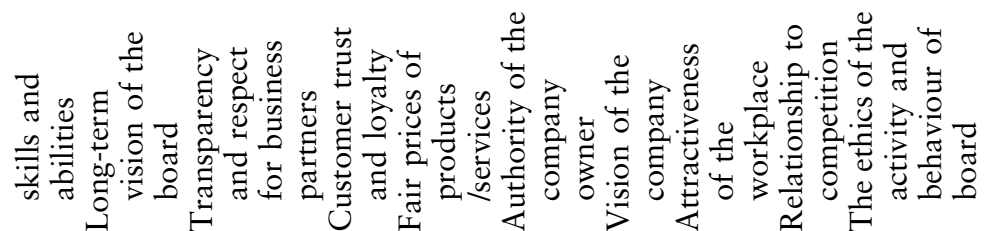




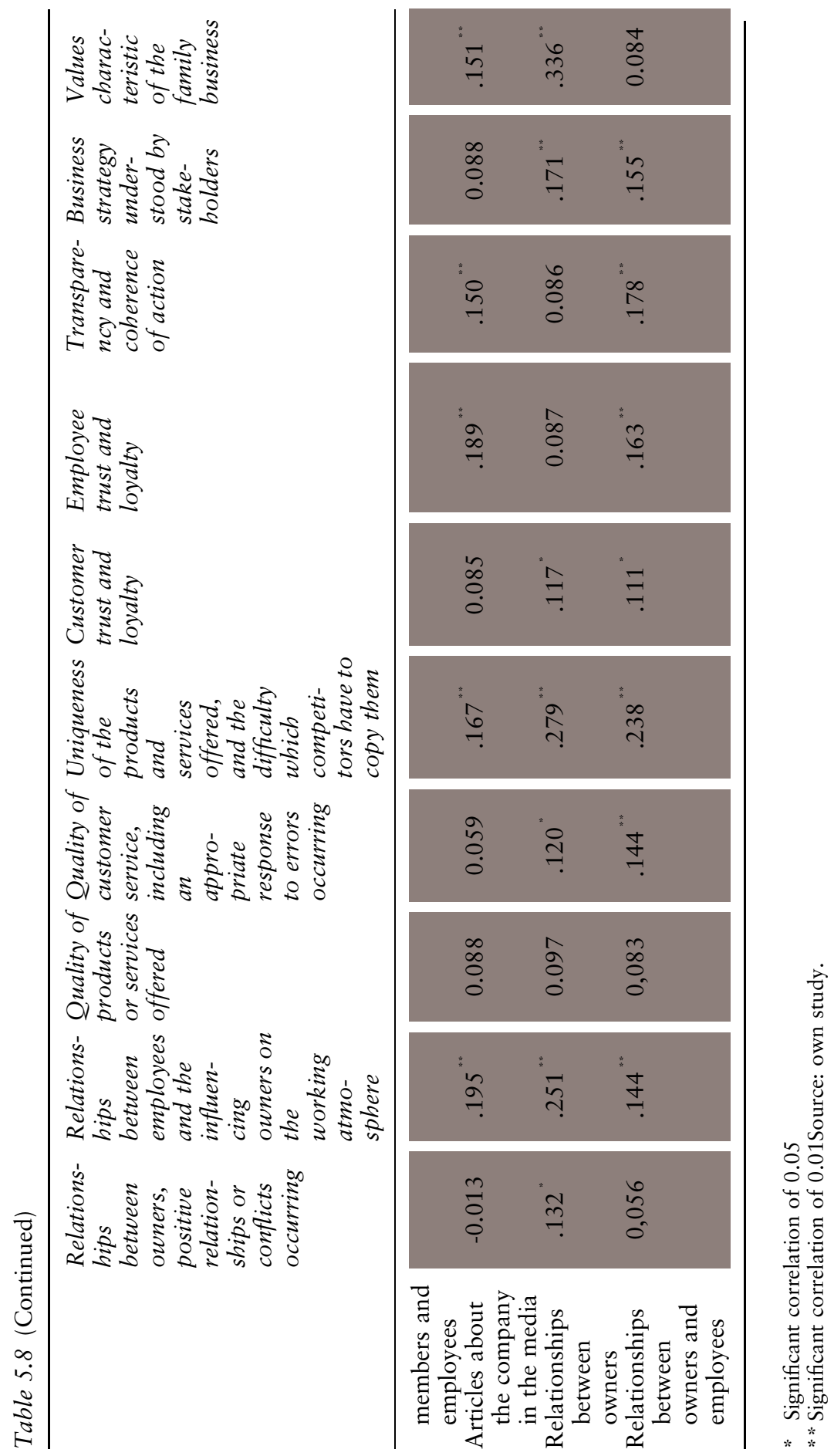


factors taken into account in the assessment of reputation are presented in Tables 5.7 and 5.8.

The data presented in Table 5.7 indicate that the definition of reputation as a relationship between owners is significantly influenced by the following reputation assessment criteria: innovation, corporate social responsibility, employees' knowledge, skills and abilities, long-term management vision, customer trust and loyalty and articles about the company in the media. Reputation assessment criteria such as the longterm vision of the board, the attractiveness of the workplace and articles about the company in the media affect the definition of reputation as the relationship between owners and employees. The definition of reputation as a way the business is perceived and evaluated by stakeholders, capable of attracting loyal customers, depends on reputation assessment criteria such as innovation and the internationalization of the company. In addition, it has been observed that employee trust and loyalty determines the definition of reputation as a form of market value of a company, the amount of which is subject to changes over time depending on the assessment of the company's activities. The perception of reputation as the essence/crystallization of what the company is, how it operates and communicates with its stakeholders is strongly linked to the long-term vision of the board. The results show that there is a positive relationship between the way reputation is defined and its assessment criteria.

The results in Table 5.8 show that there is a positive correlation between reputation assessment criteria and factors affecting reputation. The strongest link has been observed between the quality of customer service, including an appropriate response to emerging errors, and almost all factors affecting reputation. In addition, a strong link can be identified between characteristics such as relationships between owners and factors affecting reputation such as the relationship between employees and owners affecting the working atmosphere, the uniqueness of products and services offered, the difficulty which competitors have to copy them, and the values characteristic of the family business. There is also a link between the quality of products and services and factors such as the uniqueness of products and services offered, the difficulty which competitors have to copy them, employee trust and loyalty and values characteristic of the family business.

Identification of the risk of loss of reputation is the second area of action which it is necessary to take into account in reputation management (Table 5.9).

The data presented in Table 5.9 show that the strongest relationship has been observed between corporate social responsibility and - in terms of factors in the loss of reputation of a family business - working conditions and corporate culture. There is also a relationship between this reputation assessment criterion and communication and crisis management. The relationship between reputation assessment criteria such as 


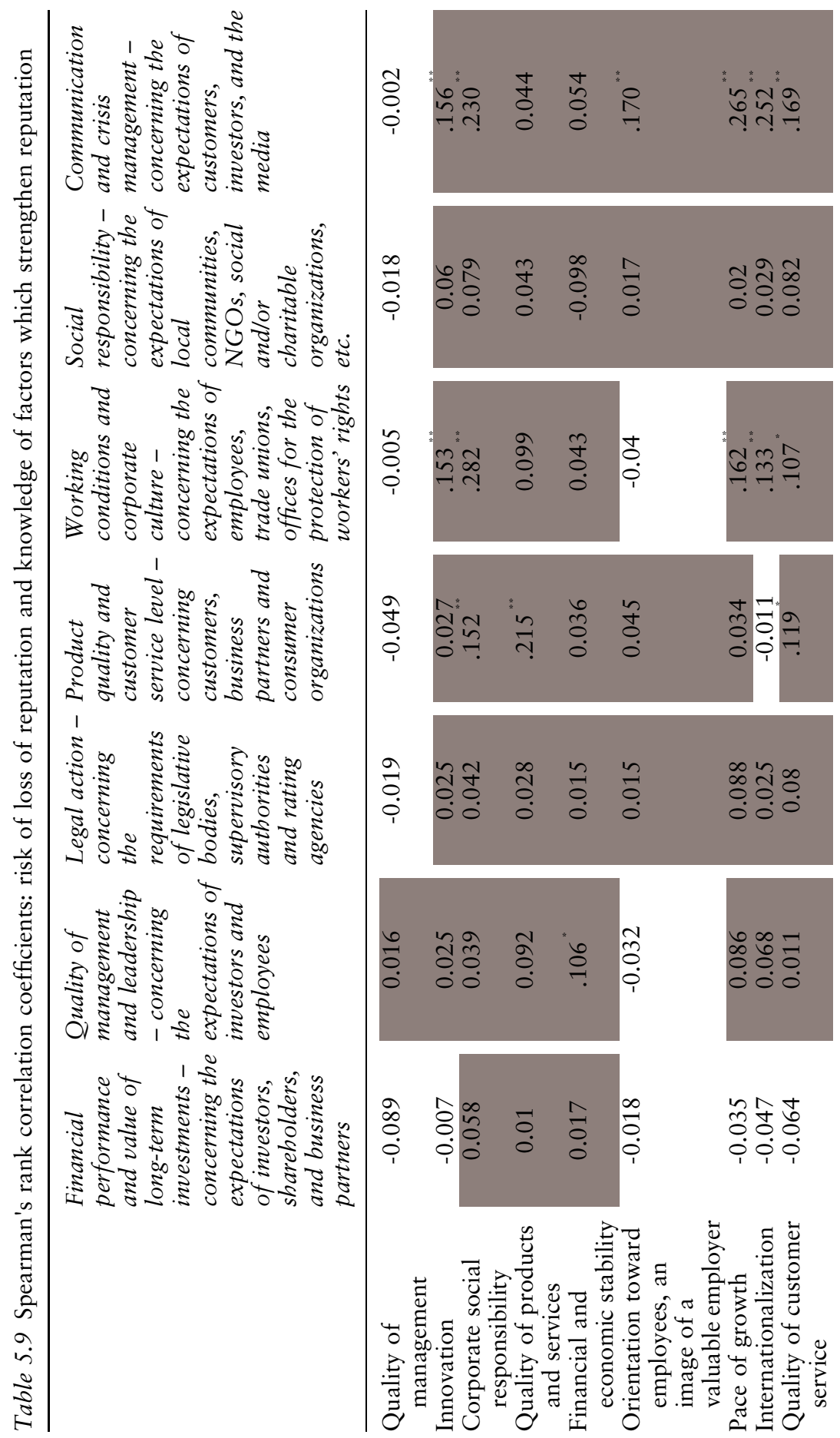



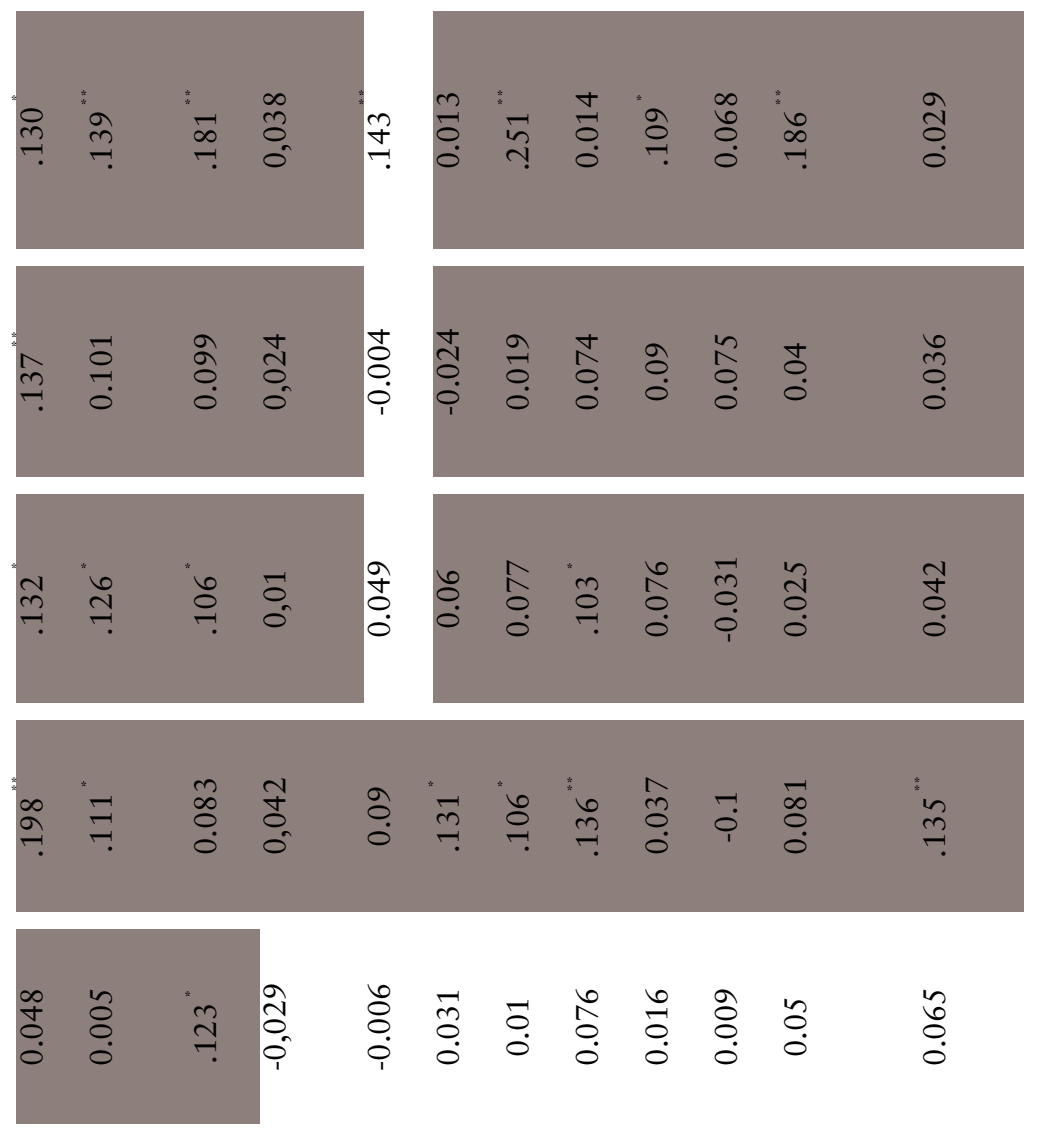

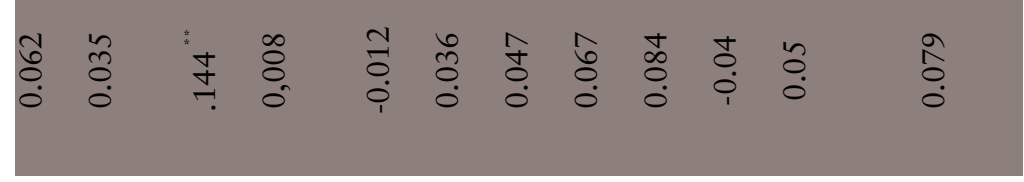
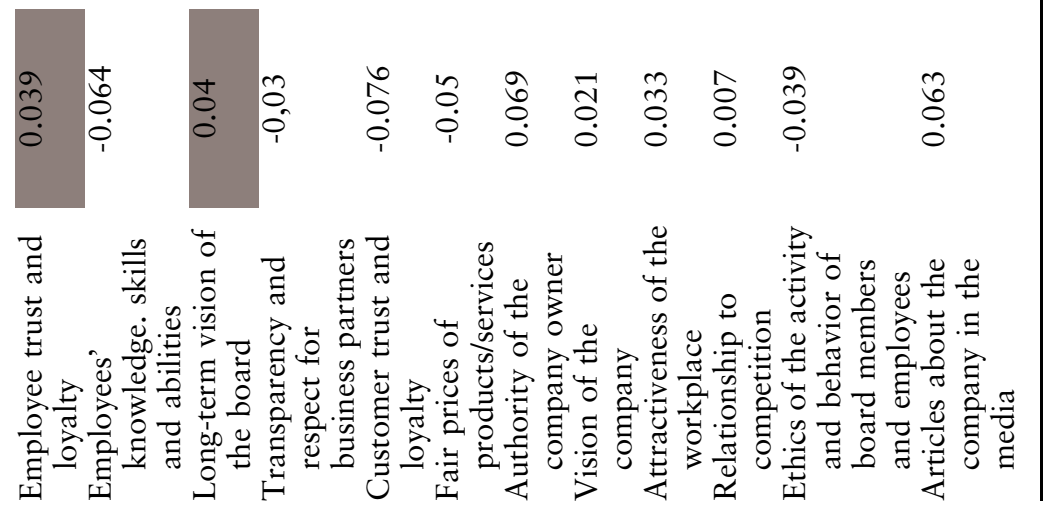


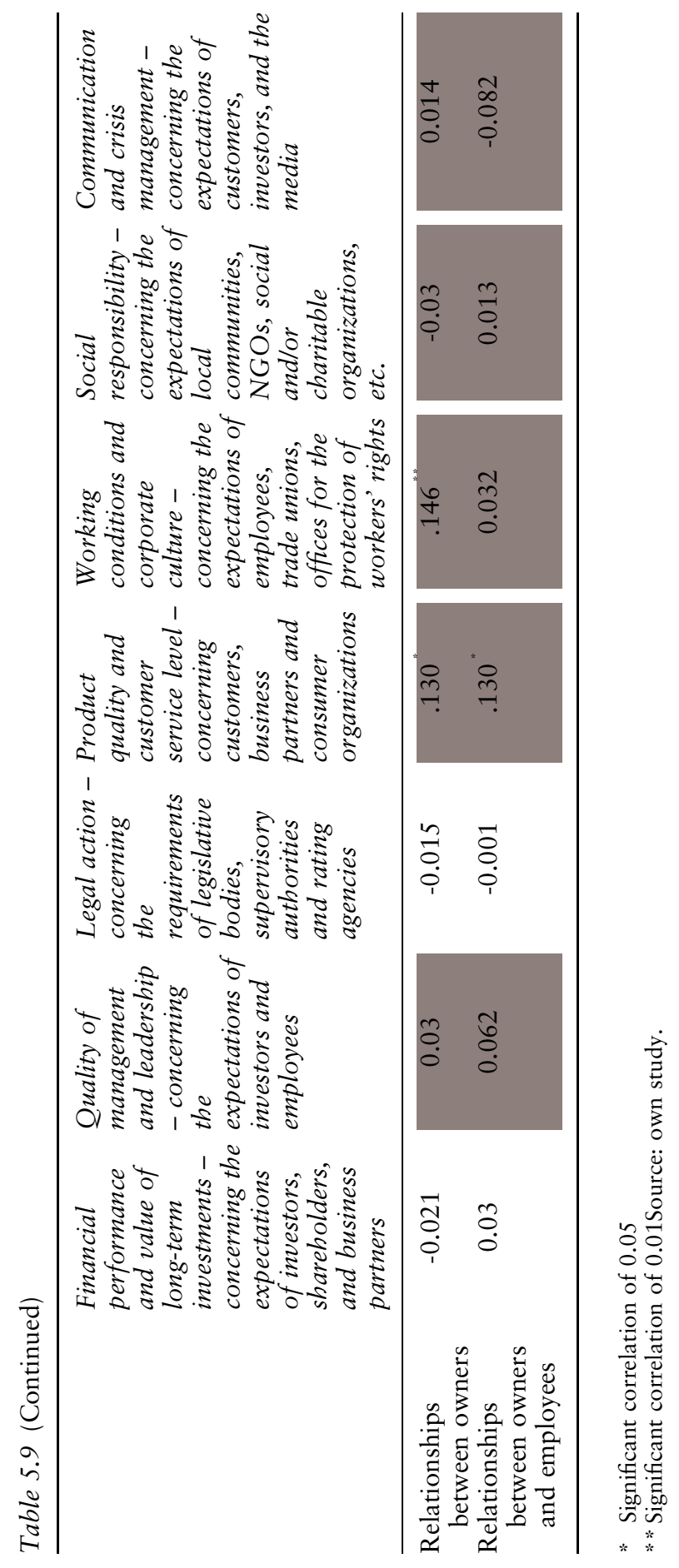


the rate of growth, the internationalization of the company and the authority of the business owner and the factor of communication and crisis management was also identified. The results show that there is usually a positive correlation between the areas. There are few negative correlations, and if they are, they are statistically irrelevant.

In view of the above, it can be concluded that the assumption that the reputation-building strategies possessed and implemented are diversified and result from the company's stakeholder orientation, the knowledge of factors affecting reputation and knowledge of factors affecting the loss of reputation has been confirmed.

Almost $40 \%$ of companies possess a reputation-building strategy in various forms. Only a very few companies participating in the survey $(4 \%)$ have a written strategic document which regulates this area - these are medium-sized enterprises, employing between 50 and 249 people $(8 \%)$, production companies $(11 \%)$ and entities which operate on the B2B market $(4.5 \%)$ - Table 5.10.

The research shows that some companies have a reputation management strategy that has not been written as a separate document, but functions as one of the core principles in the company $(15 \%)$. This type of situation is most common in production companies (23\%), as well as in companies employing 250 or more people $(50 \%)$ and operating on the B2C market (17.7\%).

The reputation-building strategy should take into account the specificity of family businesses, among which values are identified as particularly important. The impact of family business value on the value of reputation is presented in Table 5.11.

The correlation between the value of the family business and the value of its reputation as presented in Table 5.10 indicates a positive relationship. The strongest value of the correlation was observed for the value of trust, the honour of the company, profit and family reputation. The value of reputation is also strengthened by the level of care for employees who are not members of the owner's family. This observation coincides with the results presented earlier showing that employees are a key group of stakeholders of the family business. The long-term value of the company is built based on their loyalty.

\subsection{Theoretical Conclusions}

The literature review identified a variety of ways to define corporate reputation, based on aspects such as the state of consciousness, assessment and resources of significant value to the company. Representatives of science dealing with corporate reputation have repeatedly stressed that reputation is shaped by many interdependent values such as reliability, credibility, accountability, solidity, security and trust. When considering reputation, it is extremely important to determine the 
Table 5.10 A reputation-building strategy in the family businesses $(\mathrm{N}=300$, in $\%$ )

Specification

Range of values

(1) (2) (3)

(4)

Total

$\mathrm{N}=300$

Number of employees

Fewer than 10 people

Between 10 and 49 people

Between 50 and 249 people

$\begin{array}{llll}4.0 & 15.3 & 18.7 & 62.0\end{array}$

$\begin{array}{llll}- & 5.0 & 5.0 & 90.0\end{array}$

$\begin{array}{llll}2.7 & 13.3 & 20.0 & 64.0\end{array}$

$\begin{array}{llll}7.8 & 19.6 & 19.6 & 52.9\end{array}$

250 people or more

- $\quad 50.0 \quad 50.0 \quad-$

Type of market in which the company operates (predominant market)

$\begin{array}{lllll}\text { B2C market (cooperation with individual customers) } & 3.2 & 17.5 & 12.7 & 66.7\end{array}$

B2B market (cooperation with other companies) $\quad \begin{array}{lllll}4.6 & 13.8 & 23.0 & 58.6\end{array}$

Core business profile (predominant profile)

Production

Trade

$\begin{array}{llll}10.6 & 23.4 & 14.9 & 51.1\end{array}$

Service

$\begin{array}{llll}2.5 & 12.5 & 20.0 & 65.0\end{array}$

Ownership structure

$91 \%$ to $100 \%$ in the hands of the owner or his/her $\quad \begin{array}{lllll}3.7 & 15.4 & 16.2 & 64.7\end{array}$ family

$76 \%$ to $90 \%$ in the hands of the owner or his/her $\quad-\quad \begin{array}{lll}25.0 & 50.0 & 25.0\end{array}$ family

$51 \%$ to $75 \%$ in the hands of the owner or his/her $\quad$ - $\quad 50.0 \quad 50.0$ family

Overall assessment of the economic situation of the family business

$\begin{array}{lllll}\text { Good or very good } & 3.5 & 15.7 & 18.3 & 62.6\end{array}$

$\begin{array}{lllll}\text { Satisfactory } & 3.1 & 15.6 & 18.8 & 62.5\end{array}$

Difficult or very difficult $\quad 33.3 \quad-\quad 33.3 \quad 33.3$

Source: own study.

Where: (1) - Yes, we have such a strategy which is written as a separate document; (2) - Yes, we have developed such a strategy - although it has not been written as a document, it functions as one of the core principles in the company; (3) No, but the elements of such a strategy are contained in other strategic documents, customer service standards or other similar documents; (4) We do not have such a strategy and its elements are not contained in other company documents.

interrelationship between this category and image and identity, as numerous researchers emphasize that the success of the organization depends on the coherence of these three categories. The identification of the relationship between these concepts allows the organization to take a comprehensive approach to the process of image and reputation management. The literature review identified a variety of characteristics of corporate reputation. These factors include those that build a good reputation and those that create a bad reputation or result in reputational damage. As the authors point out, the awareness of these factors is crucial in terms of corporate reputation management, which should be an integral part of the organization's functioning. The analysis of the 
Table 5.11 Spearman's rank correlation coefficients: the value of a family business and the value of reputation

\section{Values}

Percentage of goodwill which is attributable to reputation

\begin{tabular}{lc}
\hline Respect & -0.04 \\
Loyalty & -0.046 \\
Entrepreneurship & -0.025 \\
Experience & 0.043 \\
Responsibility & 0.031 \\
Good atmosphere & -0.004 \\
Reliability & -0.004 \\
Good relationships between family & 0.053 \\
$\quad$ members & 0.051 \\
Stability & -0.003 \\
Heritage and sustainability & .130 \\
Profit & 0.043 \\
Common objectives & .223 \\
Trust & .113 \\
Family reputation & .142 \\
Honour of the company & 0.012 \\
Integrity towards stakeholders & 0.095 \\
Transparency in action & 0.041 \\
Coherent image & 0.021 \\
Education, knowledge & .107 \\
The welfare of an employee who is not a & \\
$\quad$ member of the owner's family & 0.047 \\
Intuition & \\
\hline
\end{tabular}

* Significant correlation of 0.05

** Significant correlation of 0.01 Source: own study.

relevant literature allowed for the positive verification of the hypothesis that the definition of the concept of reputation and its role in building company value, the definition of reputation determinants, as well as the relationship to concepts of identity and image determine the description of reputation which fulfils the requirements of a modern organization.

The analysis of the relevant domestic and foreign literature enabled the identification of key areas for building the reputation of a family business, including family business values, the company's orientation towards stakeholders, knowledge of factors affecting reputation, communication and reputation-building strategy. Publications on the management of family businesses emphasize that these organizations are characterized by exceptional specificity pertaining to the long-term internal and external stakeholder orientation, the identification of the family with the company and the formation of a unique image and building a good reputation. Researchers who deal with this issue emphasize that family values in a company are an element which integrates 
structures, processes and strategies to achieve maximum value, and that a coherent system of company value is one key company success factor. Therefore, the assumption related to the identification of key areas for building the reputation of a family company was positively verified.

When identifying the elements and determinants of the family business reputation management process on the basis of research aimed at solving the scientific problem, the following should be highlighted:

- the concept of reputation - the critical relevant literature review identified a variety of ways to define corporate reputation, based on aspects such as the state of consciousness, assessment and resources of significant value to the company. Reputation is shaped by a great number of interdependent values such as reliability, credibility, accountability, solidity, security and trust. When analyzing the available definitions and based on empirical research, it can be assumed that reputation will be understood as the essence of what a company is, revealed by the company, how it functions and how it communicates with its stakeholders - in the perception of its stakeholders. Such an approach implies the active participation of two parties in building reputation: on the one hand, a company that consciously defines its identity and tries to communicate it to stakeholders (both through their activities, "testimony", and using marketing communication tools), and on the other - stakeholders who engage in dialogue with the company. It is a tool for gaining a competitive advantage and creates intangible assets for the company. The type of market in which the company operates, its business profile and size do not significantly differentiate respondents' responses. The opinions of owners and successors are also convergent - such a convergence, or conversely a differentiation of opinion, can indicate the (un)sustainability of reputation-building activities over a long period of time;

- factors affecting reputation - in corporate reputation management, it is not only the level of reputation itself which is important, but also all the factors that may have a positive impact on it. Factors that have the greatest positive impact on strengthening the reputation of a family business include positive relationships between owners (a rating of 6.07 on a seven-point scale), customer trust and loyalty (6.05), positive relationships between employees and owners (6.03) and a high level of customer service (6.03). The importance of positive relationships between owners is particularly emphasized by micro-entrepreneurs $(90 \%)$. In micro and small enterprises, the relationship between owner and employee is usually particularly intense. They are often small teams in which owners perform their daily duties together with the people they employ, which is conducive to frequent contacts and close relationships. The high 
quality of service (including the response to undesirable situations) is the most important factor in reputation building by the representatives of service companies $(87 \%)$, which is not surprising, given that they are the most dependent on the high level of customer satisfaction with the quality of service. Services or products offered on the market can often remain similar (at least from the customer's perspective) and this quality of service is a source of competitive advantage and at the same time a decisive success factor in conditions of strong economic competition;

- in addition to factors that have a positive impact on reputation, those that pose a threat to the reputation of the family business are significant. These are "critical/node points" where good or bad opinions are created. Areas that generate a risk of loss of reputation are issues related to social responsibility (concerning the expectations of local communities or non-governmental organizations) this aspect is mainly addressed by the representatives of small entities who took part in the survey; issues related to communication and management in crisis situations (which is a particularly important issue with regard to the expectations of customers, investors, or the media) are important to those representing service providers (84\%), as well as companies active in the B2B market $(81 \%)$; working conditions and corporate culture (concerning employees, offices of protection of workers' rights) are important to service companies and small enterprises (10-49 employees);

- stakeholders - discussing corporate reputation means focusing one's attention on the company's behaviour towards stakeholders; it is highlighted that stakeholders are crucial to reputation-building; in view of the contradiction of expectations of individual groups of companies, effective reputation management requires the identification and prioritization of key stakeholder groups. The most important stakeholder groups from the point of view of family businesses include customers (average rating of 1.47 on a seven-point scale, where 1 stands for the highest rating), employees (2.33), investors (3.12) and business partners (3.65). Customers are listed as the most important group by more than $75 \%$ - most often representatives of service companies $(87.3 \%)$, while people representing production companies make such an observation relatively less frequently $(63.8 \%)$, showing that there may be a completely different relationship with the end users of their products. High results were also recorded among the representatives of micro-family businesses and B2B companies ( $80.0 \%$ and $79.3 \%$ respectively). Employees are more often identified as an important group of stakeholders by the representatives of production companies (27.7\%), family businesses operating on the B2B market, as well as the representatives of large family businesses employing 250 or more people; 
Divergent expectations of individual groups of stakeholders of family businesses were also confirmed; the respondents identify these expectations as follows: in their opinion, customers expect fairness in pricing, high-quality products and services and a high level of customer service; employees expect ethical behaviour of board members and employees, care for employees, and profitability; investors expect profitability, business ethics, and high-quality management and economy; for business partners, the following are important: respect for competition, transparency and openness and the ethical behaviour of board members and employees;

- reputation assessment criteria - in corporate reputation management, it is necessary to consider criteria/determinants that are taken into account by stakeholders when assessing the company and thus affecting the level of the company's assessment. This issue was very important to the respondents representing family businesses. All the determinants presented for assessment reached an average of more than 5.50 on a seven-point scale. Moreover, except for one determinant defined as "internationalization of the company", none of the 300 respondents indicated two lowest values on the scale while assessing other determinants. The distance between the highest and the lowest rated determinant is only 0.38 , which means that, in the opinion of the respondents, all these factors should be taken into account in actions taken to ensure good corporate reputation, and are almost equally important. The highest-rated determinants are the quality of products and services, corporate social responsibility, customer trust and loyalty, the relationship to competition, financial and economic stability, transparency and respect for business partners, fair product prices, including services;

Cluster analysis showed that, in terms of substantive similarities, the following factors generate reputation assessments determinants: 1) related to building intra-organizational stability, which is the basis for ensuring long-term functioning, 2) related to building relationships with individual stakeholder groups, 3) changing the company's past patterns of behaviour by demonstrating an openness and willingness to develop the company, 4) related to the improvement of the company's functioning;

- communication with stakeholders - each company aims to shape its own image and positive reputation. They should be conducive to the development of the company and, above all, be fully coherent and in line with the strategy adopted. In family businesses, the following are most widespread: advertising, PR and image creation projects, followed by educational activities and sponsorship of sporting or cultural events (the latter is rarer than the former), then charitable actions, while the various forms of cooperation with the non- 
governmental sector or social economy entities are the rarest. Advertising campaigns are primarily conducted by medium-sized companies $(78 \%)$, production companies $(79 \%)$, while service companies undertake social media activity more often than others $(70 \%)$;

Advertising and PR campaigns should be complementary among reputation-building activities. These are based on a firm foundation of the company's real activities. The activities of family businesses which build reputation and eliminate the risk of loss of reputation are primarily aimed at offering customers high-quality products and services, care for customer satisfaction, care for good relationships with customers, integrity, adherence to ethical principles of running a business, reliability, transparent rules and high levels of transparency, conflict prevention and resolution. The company profile, size and the type of customer supported vary respondents' answers slightly;

- reputation-building strategy - reputation management requires controlling "node points" - places where good or bad opinions are created. Fewer than four out of ten companies have a planned reputation management policy. Some have a reputation management strategy that has not been written in a separate document but functions as one of the fundamental principles in the company $(15 \%)$. This is most common in production companies $(23 \%)$, as well as in companies employing 250 or more people $(50 \%)$ and operating on the $\mathrm{B} 2 \mathrm{C}$ market $(17.7 \%)$. In the case of $19 \%$ of the respondents, the components of the reputation management strategy are fragmented, i.e. they are found in other documents covering different areas of the company's operation. These are most often customer service standards, as well as documents which regulate core values or ethical principles in the company, such as anticorruption policy, transparency of behaviour, functional strategies, and principles of cooperation with business partners. They are usually entities operating on the B2B market, i.e. providing services to other companies (23\%). $62 \%$ of the companies surveyed do not take this kind of action. It is clear that the size of the company influences the pursuit of a policy of planning reputation-building activities - the higher the number of employees, the more often economic entities do so;

- The importance of family business values in building reputation - an extensive review of the relevant literature shows that the distinguishing feature of family businesses and the starting point for family business reputation management are its values. The most important values of a family business when it comes to building a good reputation are trust (a rating of 5.95 on a seven-point scale, where 7 means the highest rating), integrity towards stakeholders 
(5.93), reliability (5.91), profit (5.91), accountability (5.90) and good relationships between family members (5.89). There is a relationship between a company's values and its objectives: if the company is committed to achieving common goals, it will appreciate employees' knowledge, skills and abilities; if the value is profit, it will be linked to employee trust and loyalty, the quality of customer service, including the appropriate response to errors occurring, and the authority of the company owner; reliability is linked to employee trust and loyalty, and responsibility to the ethics of the activities and the behaviour of board members and employees. Good relationships between family members are linked to the vision of the company and the attractiveness of the workplace, as well as respect for the longterm vision of the board. If trust is a key value of a company, it is important to inspire the trust and loyalty of customers, the relationship between owners, the ethics of their business and the ethical behaviour of board members and employees;

The values followed in the company also determine the way of understanding reputation: the identification of reputation with "the way a company is perceived and evaluated by stakeholders capable of attracting loyal customers" shows a link with values such as coherent image, education and knowledge, family reputation and trust. The strongest correlation was observed for the following determinants: "reputation is a form of market value of a company, the amount of which can be subject to change in time depending on the assessment of the company's activities" and the value of heritage and sustainability, as well as the relationship with family reputation and the honour of the company. There is also a correlation between values such as coherent image, education, knowledge and family reputation and the understanding of corporate reputation as a way for stakeholders, capable of attracting loyal customers, to perceive and evaluate the company. The following family and business values influence the definition of reputation as an intangible asset: the honour of the company and coherent image. Furthermore, it has been observed that a value such as profit affects the definition of reputation as a barrier to market entry;

Values are also linked to the characteristics of family businesses that strengthen their reputation. The strongest relationship was observed for the quality of customer service, including an appropriate response to emerging errors and profit. There is also a relationship between this feature and experience, trust, care for the welfare of an employee who is not a member of the owner's family, and family reputation. A correlation also occurs between relationships between employees and owners affecting the work environment and profit, trust and family reputation. The uniqueness of the products and services offered, as well as the difficulty competitors 
have to copy them, is correlated with heritage and sustainability, a good atmosphere and profit. There is also a correlation between profit and the following factors affecting reputation: relationships between employees and owners affecting the work environment, the business strategy understood by stakeholders, and values characteristic of the family business;

- succession and sustainability of reputation management - in the family businesses which were the subjects of this research, the sustainability of reputation is emphasized. It is crucial in terms of the management of this valuable intangible asset that the owner and successor have a similar family and business value system, and a similar understanding of the essence of reputation or its importance for the operation of the entire company. Both owners and successors have a similar understanding of the essence of reputation (which bodes well for these companies for the future, including the sustainability of their reputation); they also have similar opinions about the benefits of good reputation, despite their generational differences. Looking at family and business values professed by the owners and successors of the organizations surveyed, it can be noted that there are no significant differences between their opinions, either;

- the value of the reputation of the family business - according to various sources, it is estimated that reputation can account for between $20 \%$ and $90 \%$ of the company's market value. According to the representatives of family businesses who took part in this survey, the reputation of a family company can account for $46.5 \%$ of its market value on average. However, nearly six out of ten respondents believe that reputation can account for $40-50 \%$ of the market value, and nearly three out of ten believe that this share may exceed half of the market value.

In the opinion of family businesses, the most important benefits of having a good reputation include more sales, lower marketing costs, higher profits, higher growth potential and improved image.

In the discussion on family business reputation management, the following principles of reputation management were analyzed: focus, distinction, coherence, identity, transparency, signal filtering and response. Compliance with these rules allows managers to effectively build and manage the reputation of their family businesses.

The analysis of the relevant literature gives rise to the conclusion that there is no single universal standard for corporate reputation management. However, its core components can be identified, namely constitutional relations (defining stakeholder groups, identifying their behaviour, developing standards according to which companies design their practices towards stakeholders), practices in building reputation (business strategies and systems used to build reputation and 


\section{Evaluation, Conclusions \& Recommendations}

relationships with key stakeholder groups), organizational issues (methods by which companies undertake reputation management, and having a "reputation-building strategy"). It also includes the following processes: defining identity and identifying the need to externalize it through actions targeted at individual stakeholder groups, actions targeted at individual stakeholder groups which reflect the obligation to exceed standards at work and outside work, actions that companies take to convey their identity to key stakeholders and influence their perception, and constantly listening to determine whether its message has been accepted and to reduce the gap between the perception of stakeholders and the perception of a corporate identity. As highlighted, reputation is a concept that, in order to be implemented in the long term, must be linked to the company's fundamental strategies and objectives, with its mission, values and vision.

On the basis of the relevant literature, it is assumed that reputation management is a process in time covering the following stages: the assessment of the baseline situation, the anticipation of potential risks, the measurement of the likelihood of an event likely to affect reputation, the determination of the organization's response to risk and the monitoring and simulation of events affecting reputation. Taking into account the identification of key components of family business reputation management, methodological assumptions that determine the solution to the scientific problem (induction method and the method of grounded theory), as well as the previously discussed proposals to manage reputation and the structure of the reputation management process, an original concept of family business management was developed. This concept takes into account areas such as family business values, a company's stakeholder orientation, knowledge of factors affecting reputation, communication and reputation-building strategies. The literature review and theoretical discussion have therefore allowed for a positive verification of the assumption about the areas to be covered by the concept of family business reputation management.

\subsection{Practical Recommendations for the Use of the Concept of Family Business Reputation Management}

The research results showed that key stakeholders who have the greatest impact on the functioning of the family business include customers, family business employees, investors and business partners. Therefore, family business managers should focus on these stakeholder groups and their needs. The research also shows that customers and employees are the most important stakeholder groups in the family business, and the relationship between them and owners is one of the most important factors affecting the reputation of the family business. According to empirical research, the least important stakeholder groups for family 
businesses are local communities, media and public administration at different central, regional or local levels. It is worth remembering, however, that these groups should not be ignored in the management process of a family business, since they can contribute to building a positive corporate reputation, albeit to a lesser extent than key stakeholders.

In order to build long-term relationships with key stakeholders, family businesses should respond as much as possible to their expectations. Knowledge of the expectations of key stakeholders can significantly improve the quality of their relationship with a family business. According to the respondents, family business customers expect them first of all to be fair in setting prices, to offer high-quality products and services, as well as high-quality customer service, while employees expect family businesses to be profitable in the first place, followed by concern for employees and the ethical behaviour of board members and employees. According to the founding families and managers, the expectations of investors are similar to those of employees, namely profitability, financial and economic stability, and the ethics of their activity. In turn, the expectations of business partners include respect for competition, transparency and openness, as well as the ethics of board members and family business employees.

A crucial aspect of family business reputation management is the knowledge of factors affecting the assessment of corporate reputation. As research shows, the assessment of the reputation of a family business is influenced by factors related to building intra-organizational stability, which underlies the long-term functioning, building relationships with individual stakeholder groups, changing the company's past patterns of behaviour, demonstrating openness and a willingness to develop the company, related to the improvement of the company's functioning. When developing and pursuing their strategy, family business managers should take these factors into consideration.

In the process of family business reputation management, taking the principles of social responsibility into account in business activities should also be important. The research shows that the main risk factor for loss of reputation is social responsibility issues related to the expectations of local communities or non-governmental organizations. At the same time, these results indicate that the risk of loss of reputation can be eliminated by taking measures such as offering customers high-quality products and services, care for customer satisfaction, ensuring good relationships with customers, integrity, adherence to ethical business rules, reliability, transparent rules and a high level of transparency and conflict prevention and resolution.

A key success factor for a family business may be the pursuit of a wellthought-out and planned reputation management policy. According to research results, only a small percentage of family businesses have a 


\section{Evaluation, Conclusions \& Recommendations}

written strategic document regulating reputation management, which can constitute a distinguishing feature and source of competitive advantage in the market. It can be profitable for a family business to develop such a strategy, since the reputation of a family business can account for almost half of its market value on average.

Involvement in the process of implementing the concept of reputation management can bring a number of tangible benefits to the family business, which can primarily include an increased level of sales and reduced costs of broadly defined marketing activities. In addition, the reputation of a family business primarily affects the building of a position of a valuable employer, building and strengthening customer loyalty, and easier cooperation with investors and recipients.

As the research shows, values professed by organization members are a vital component in the process of family business management, which should be based on values such as loyalty, stability, and honour. Cultivating these values can contribute to building a positive corporate reputation, which, as research shows, is a source of competitive advantage of a family business.

Effective family business reputation management requires suitable communication activities addressed to its key stakeholders. Research shows that family businesses are most likely to use media advertising campaigns and social media for this purpose. Therefore, the use of these channels can have a positive impact on the quality of communication between the family business and its key stakeholders. 


\section{Conclusion}

Professionalization is one of the essential requirements facing modern organizations (Drucker, 2009; Koźmiński, 2008; Nogalski, Śniadecki, 2001). Management seeks answers to the following questions in its research and theories: what does the success of the organization depend on? How to effectively organize and use the company's resources? How does the organization respond to changes in its environment, e.g. changes in buyers' preferences or technological development? Intangible assets, such as corporate culture, brand, identity, image and reputation and customer relationship capital, if properly designed and managed, should be considered vital to strengthening the competitive position of the company and thus increasing its value. Reputation defines the state of trust in a company or the lack thereof, and as a result, it is the sum of opinions of different recipients and affects the creation of market value.

The issues of reputation, its essence, shaping, determinants, reputation management and influence on the various areas of the organization's functioning are very interesting, broad and particularly important in the context of changes taking place in modern organizations. The importance of the issue of reputation management in management sciences arises from the fact that, as both theorists and management practitioners have observed, it is important in terms of gaining long-term competitive advantage and building company value. They, therefore, point to the need to build, maintain and protect a positive reputation, i.e. the need to manage reputation, which, due to its complex and multidimensional nature, is a serious and difficult challenge.

This work attempted to identify and determine the importance of family business reputation management. By placing both issues (i.e. reputation and the specific character of family businesses connecting the family and business environments) in a broader organizational context, an attempt was made to verify this relationship. The scope of the presented issue and the adopted research concept are a response to the research gap indicated in the introduction to this work. The literature review confirms that the issue of family business reputation management is relatively poorly recognized. While a great deal of attention in research

DOI: $10.4324 / 9781003226215-102$ 


\section{Conclusion}

has already been paid to reputation and the issue of family business management in many aspects has already been recognized, the relationships between these different aspects have received less attention. Interest in this subject also results from the conviction of its importance, both in theoretical and practical terms. All the research objectives have been achieved. The aim of both the theoretical and empirical research was to develop a concept of family business reputation management. It was assumed that adopting the concept of reputation management in a family business in a more or less formal way enhances the level of corporate reputation and affects the areas of the family business. The reputation management strategy (in the form of a study/document, or less formally as a concept present in the company, which summarizes certain strategic company objectives in this area), which a family business creates and implements to manage tangible and intangible assets and relationships in the business environment, is a tool for enhancing competitive advantage. The scientific exploration of the issue included in particular:

- the review, systematization and synthesis of views on the understanding of the concept of reputation and its role in building company value, the determinants of reputation, as well as its relationship to related concepts such as identity and image in light of the relevant literature, different approaches and research trends;

- the identification of the characteristics and distinguishing features of family businesses, reputation-building areas and resources involved in the processes of building the reputation of a family business, as well as key context pertaining to internal and external factors which strengthen/limit the reputation of a family business;

- the description of determinants, components and processes in the field of corporate reputation management, and the identification of key links between them;

- the identification of crucial components of the concept of family business reputation management and relationships between them;

- the development of theoretical conclusions and practical recommendations for using the concept of reputation management to improve the functioning of family businesses.

The identified research gap and the specific research objectives outlined above gave rise to the development of the conceptual model, followed by the research model and the formulation of research hypotheses. The analysis of literature and methods of quantitative analysis were used to verify them.

A resource-based view assumes that organizational success is based on a specific configuration of resources and skills. Reputation management, due to its amorphous, delicate and elusive nature and the involvement of 
the attention of individual groups in the business environment, places particular demands on owners and managers of family businesses, as well as their employees, whose working environment is determined by family and business values, strong family influence and problems related to succession. The research confirmed the importance of reputation management in the development of a family business. Various concepts of reputation were exhaustively presented in the book, while paying attention to the areas of application in research on reputation. In the course of the analysis, classic and contemporary approaches to reputation were presented. The rich achievements of the relevant domestic and foreign literature on the issue of reputation combine it with the subjects of identity and image, as well as trust. The starting point for further analyses was the adoption of a definition of reputation. The diversity of the views presented in literature grouped them into three basic approaches: reputation as (a) "awareness", (b) "assessment" and (c) an "asset component".

Based on statements from the literature review, looking for further relationships, empirical research was conducted for the key areas of family business reputation management. When analyzing the available definitions and based on empirical research, it can be assumed that reputation will be understood as: the essence of what a company is, revealed by the company, how it functions and how it communicates with its stakeholders from their perspective. Such an approach implies the active participation of two parties in building reputation: on the one hand, a company that consciously defines its identity and tries to communicate it to stakeholders (through their activities, "testimony", and using marketing communication tools), and on the other - stakeholders who engage in dialogue with the company. It is a tool for gaining a competitive advantage and creates intangible assets for the company.

Stakeholders are an indispensable participant in the process of building reputation. Reputation cannot be discussed without referring to the perception of stakeholders.

Corporate reputation consists primarily of opinions, views and judgements of the external environment. The author adds that these are objective opinions, but whenever an interaction occurs, it is difficult to avoid the subjectivity of judgment, opinion, or view. It is important to note, however, that reputation depends on credible actions, responsibility, the fulfilment of promises, as well as ethical and open behaviour, which should minimize this subjectivity of assessment. Reputation determines the state of trust or mistrust in a company and as a result is the sum of opinions of different recipients, which affect the creation of company value.

Family businesses combine business activities with the family sphere. Due to today's management conditions, family business managers face a number of strategic and operational management problems, as well as 


\section{Conclusion}

specific challenges arising from the circumstances and rules of family business. Problems related, inter alia, to the development of corporate strategy, corporate culture and corporate social responsibility are linked to the issues of succession, values and management by means of said values and social family capital. The specificity of family businesses is that the owner's family shapes the company in a way that family members cannot do in non-family-owned businesses.

One of the characteristic features of the functioning of family businesses is orientation towards different groups in the environment, which include company customers and employees, who have the greatest influence on the functioning of the family business. Other stakeholder groups identified by the respondents are investors and business partners.

It is also important for family businesses to follow values which are important to stakeholders in their business. According to the respondents, the most important stakeholder group, i.e. customers, expects first of all fairness in pricing, high-quality products and services, and high-quality customer service. In turn, employees expect profitability, care and the ethical behaviour of board members and employees. In addition to profitability, investors also paid attention to financial and economic stability and the ethics of the activity. Family business partners pay attention to respect for competition, transparency and openness, and the ethics of board members and employees of family businesses.

In assessing the company, stakeholders take four factors affecting the level of this assessment into account. These include factors related to building intra-organizational stability, which are the basis for ensuring long-term functioning, elements related to building relationships with individual stakeholder groups, and factors related to changing the company's past patterns of behaviour by demonstrating an openness and willingness to develop the company, as well as factors related to the improvement of the company's functioning.

According to company owners, a very important element of the functioning of family businesses is the knowledge of factors affecting its reputation. In terms of the effective management of the company's reputation, it is not only the level of reputation itself, but also all those factors that affect this reputation. The factors which are crucial to the positive reinforcement of the reputation of the family business were positive relationships between owners, customer trust and loyalty, positive relationships between employees and owners and a high level of customer service. The indication of these factors is confirmed by the previous conclusion - customers and employees are the most important stakeholder groups of the family business, and the relationship between them and the owners are among the factors that have the strongest impact on the reputation of the family business. In addition to shaping the right image and positive reputation, it is very important for family businesses to communicate this image to the environment, and this 
communication has to be consistent with the strategy adopted. Actions that family businesses should use to counteract the loss of reputation by the company include offering customers high-quality products and services, care for customer satisfaction, care for good relationships with customers, integrity, adherence to ethical principles of running a business, reliability, transparent rules and high levels of transparency and conflict prevention and resolution.

Taking care of one's reputation is one of the challenges which family businesses face. The prevention of reputation-related risks that have increased and become more complex is equally important. A reputation management tool can be a functional strategy. According to the research, a small number of companies participating in the survey have a written strategic document regulating the area of reputation management. Some companies have a reputation management strategy that has not been written in a separate document, but functions as one of the fundamental principles in the company. For some companies, the components of the reputation management strategy are fragmented, which means that they are found in other documents that describe the different areas of the company's operation. Most of the companies surveyed do not take actions related to strategic reputation management. Building a strategy depends on the number of people employed - the more employees there are, the more the organization engages in this area. In addition, there are a number of risks that may jeopardize corporate reputation. The most frequently identified issues include social responsibility, the expectations of local communities or NGOs and issues related to communication and management in crisis situations, which is a particularly important issue with regard to the expectations of customers, investors or the media.

The succession process, which should be conducted efficiently and be closely linked to the organizational strategic objectives, is also significant in family business reputation management. This process can have both a positive and negative impact on corporate reputation and the company's continued functioning. Since family businesses are characterized by a particular attachment to tradition, it is very important to transfer the values of the existing owners to the successor. Successors very often face a dilemma of further cultivating values and the need to respond to changes in the environment. Successors must identify and maintain the values that created the company's own essence, while also defining values that allow innovation and the anticipation of market changes.

This monograph is based on the latest relevant literature and the author's own research and experience. It contributes to enriching knowledge of family business management. The author is aware that the content contained in this work does not fully exhaust the issue at hand. However, given the up-to-date nature of the problem, it should contribute to further research. 


\section{Future Research Directions And Limitations}

The issue addressed in the study needs further research. From the cognitive perspective, future empirical research should include an in-depth analysis pertaining to both the different types of organizations, including company size, type (production/service) and the industries in which they operate, while taking into account the impact of external factors on the reputation-building processes and corporate reputation management. It would be valuable to conduct them on larger samples, especially among the best companies in terms of reputation. In light of globalization processes, international comparisons in this area should also be taken into consideration. It is also worth extending the research by involving individual stakeholder groups of family businesses.

Reputation is often associated with only the opinions of stakeholders, external perceptions of the company - something independent of the company. People's roles and capabilities and psychological limitations are still underestimated in terms of organizational processes. This is a fragmentary approach. The dynamics of the reputation-building process surprises managers, revealing a lack of understanding of its processes in the organization, including factors that positively stimulate them. To date there has been no integrated research into problems arising from the need for multi-level reputation management, while the process of reputation building and management is conducted in the social system of an organization that has specific conditions both at the organizational (including corporate culture or structure), group (including leadership style) and individual (including creativity, knowledge, competence, personality and learning) levels. Therefore, in future research it would be worth taking into account the possible diversity of relationships between components examined at individual, group and organizational levels, including them in integrated studies of multi-level conditions for reputation management in the organization.

An important direction for future research is the impact of the environment on the effects of individual dimensions of the family business operation. Decentralization is becoming increasingly important in a dynamic environment, and the need for differentiation is increasing. Given the diversity of the organization's environment, including the types of markets, different environments may have a different impact on family business reputation management. The impact of communication technologies on building opinions about the company is also significant.

Survey and interview methods are not insusceptible to the process of respondents' self-presentation and creation (Kożusznik, 1994). The specificity of managers is vast social experience, knowledge of games and social "rituals" used to make the desired impression. It is characteristic of respondents to give the "right" answers, i.e. those that say how it should be. Managers know (e.g. from their participation in MBA 
programs, training and conferences) what the right answers are and respond as such instead of expressing opinions in line with their behaviour and attitudes. Therefore, in future research it would be interesting to supplement it with other "non-straightforward" research methods, projection techniques or observation during the performance of tasks; this is an important aspect of studying characteristics - attributes contained in the model of managerial competencies.

The limitations of this work are primarily related to the direct research method. Despite numerous advantages, the interview method has certain inherent disadvantages, which largely determine the quality of the results obtained. First of all, the information collected is based on respondents' declarations rather than on the observation of their actual behaviour. In addition, the truthfulness of responses may have been influenced by interviewer error and by the variable of public approval. The limitations also include the problem of complete literature reviews. The increasing number of studies on both reputation and family business management makes it very difficult to conduct systematic literature reviews, which would undoubtedly increase the value of the work. Finally, the companies surveyed were at different stages of development, and their reputation could be due to potential as much as reality in some cases. In addition, managers have diverse experiences, which change the perception of reputation in the ranking of the importance of problems in family business management. All this leads to a conclusion of the necessary cautions with regard to research findings, which require the continuous verification in a rapidly changing reality and a "volatile economy".

\section{References}

Drucker, P. (2009). Menedzer skuteczny [An effective manager]. Warszawa: MT Biznes, pp. 13.

Koźmiński, A.K. (2008). Koniec świata menedżerów [The end of the world of managers]. Warszawa: Wydawnictwa Akademickie i Profesjonalne.

Kożusznik, B., ed. (1994). Psychologia w pracy menedżera [Psychology for managers]. Katowice: Wydawnictwo Uniwersytetu Śląskiego.

Nogalski, B. and Śniadecki, J. (2001). Umiejętności menedżerskie w zarządzaniu przedsiębiorstwem [Managerial skills in enterprise management]. Bydgoszcz: Oficyna Wydawnicza Ośrodka Postępu Organizacyjnego. 


\section{Index}

Note: Italicized page numbers refer to figures, bold page numbers refer to tables

A.J. Blikle 56

AA 1000 Accountability Principles Standard (AA1000APS) 117

AA 1000 Assurance Standard (AA1000AS) 117

AC2ID model 30

AC3ID model 30

AC4ID model 30

accounting goodwill 122

Acedo, F.J 80

ACID model 30

actors 112

Adamczyk, J. 73, 113

Adams, J.S. 74

Adamus-Matuszynska, A. 3, 67, 114 advertising 4, 36, 40, 99, 156, 208-209

advertising campaigns 214

Albert, S. 24

Alessandri, S.W. 23

Ali, Z.A. 57

allies 96

Alsop, R. 38

Altkorn, J. 33

American Reputation Institute 2, 39

assessment of reputation 2, 176-180, 200-203, 217; business values in family businesses $\mathbf{1 7 5}-\mathbf{1 8 0}$, 183-187; characteristics of family businesses 185-187; criteria 208; definition of reputation 191-194; determinants of 176-180; determinants of value of reputation 188-189; factors affecting family business values 189-190; factors in 191-194, 219; family business- building strategies 190-203; in family businesses 145-148; family values in family businesses 183-187; reputation-building strategies 190-203; risk of loss of reputation 200-202; stakeholder assessments 195-198

Astrachan, M.C. 55

Auchan 56

awareness 2, 17, 19, 35, 170-171, 217; of CEO 72; collective 67, 71; of family businesses 73 ; moral 67 ; of values 108

B2B companies 140, 161

B2C companies 161

bad reputation 40-41, 96, 204

Baden-Fuller, C. 17

Balmer, J.M.T. 17, 30, 36, 114

Banco Santander 56

Barnett, M. 19, 121

Bazzichi, O. 114

Bechtel 56

Benetton 56

Berrone, P. 74

Bjuggren, P.O. 76

Blajer-Golebiewska, A. 121

Blikle, A. 57

Blikle, A.J. 56

Boguszewicz-Kreft, M. 77

Bojanczyk, M. 2

Bosch, Peter 56

Botin, Emilio 56

Bowd, L. 121

Bowd, R. 121

Bowen 114 
Brammer, S. 121

brand(s) 1, 56, 104; building 34; buyers' choice of 32 ; capital 15 ; concepts 22 ; creation of 36 ; depreciation 63; family businesses 59-60; financial and non-financial dimensions 34-35; Polish 56; recognition 20; reputationstrengthening factors 195-198; strong 40

Bratnicki, M. 27-28

Brooks, C. 121

Brown, M.B. 76

Budzyuski 33

business partners $40,82,96,111,120$, 140, 141-142, 144, 145, 162, 170-171, 175, 181, 208, 209, 212, 212-213, 213, 218

business values $63,167,174-189$, 175-180, 181-182, 183-187; factor affecting 189-190

\section{Cargill 56}

Carrefour 56

Carroll, C.E. 97, 114

Casillas, J.C. 80

character, reputation of 118

charismatic leadership theory 68-69

Chelpa, S. 106

Chernatony, L. 31

chief executive officers (CEOs):

charisma of $68-72,70$; and

reputation of family

businesses 67-68

chi-square test of independence 139

Chmiel, J. 15

Chodynski, A. 19

Chrisman, J.J. 74

Chua, J.H. 74

Clarkson, M.B.F. 114

cluster analysis 138-139

Cochran, P.I. 114

ComArch 56

communication with stakeholders 114-119, 156-161, 157, 208-209, 217

companies with family identity 53 company valuation $122,123,124$ competence, reputation of 20,118 competitors 29, 36; and business values 182; and charisma of CEO 69; expectations and values of 115-116; horizontal relationships
112; reputation assessment criteria 199; and reputational paradox 41; and stakeholders 103

conflicts 102

consistency principle 97, 99

constitutional relationships 102

co-operators, expectations and values of 115

Corley, K.G. 41

corporate culture 27; anthropological approach 27-28; capital 15

corporate identity 22-23; components of 30; concepts 22-23; definitions of 24-27, 26; factor shaping 28; functionalist terms 27 ; interpretative-symbolical terms 27; management models 30-31; in management process 24-30

corporate identity management 36 corporate image 22-23; definition of 23; financial and non-financial dimensions 34-35; functions of 32; influences on 35 ; integrated 35 ; intended 36

corporate reputation 4; assessment and 2; asset components 4; awareness and 2; concepts 22-23; criteria 37-42, 39; determinants of 37-42, 39; financial and nonfinancial dimensions 34-35; stakeholders 3; trends in 32 corporate social responsibility (CSR) $3,6,37,38,72-75,80,95,117$, 156, 199, 208, 218

COSO-ERM model 103

crisis management 96, 120

critical/node points $162-163,207$

Cruz, C. 72,74

customer(s) 58, 96, 141-142, 145, 175, 190, 207; expectations and values of 115,218 ; relationship capital 15 ; relationships $1,15,215$; support 40, 209

Dabrowski, T. 2, 37

data analysis 138-139

Davies, G. 96, 101

De Massis, A. 74

decentralization 220

digital economy 15

distinction 22, 23, 26, 29, 79, 124, 211

distinction primciple 98 


\section{Index}

distinctiveness principle 97

Dow Jones 56

Dowling, G.R. 33, 96-97

Dr Irena Eris 56

Drucker, P.F. 114

Dworak, F. 20

economic goodwill 122

economic value added (EVA) indicator 27

Edelman Trust Barometer 39

Elsbach, K. 41

emotional influence 101

emotional motifs 98

employees 96, 138, 145, 175, 212-213; expectations and values of $\mathbf{1 1 5}$

enterprise management 38, 57;

reputation and 15-24

environmental impact 220

essence of reputation 183-184

European Commission 78

experts, relationships with 112

Faber-Castell 85

Fakro 56

family business managers $3,68,80$, $81,212,213,217,217-218$, 220-221

Family Business Network 78

family business reputation 149

family business reputation management 134-172; assessment of 174-203; assumptions in 109; basic approaches 217; concept of 105-110, 107; core processes 108; essence of reputation 183-184; factors influencing reputation 151-156, 154-155; family business value and 174-189, 175-180, 183-187; future research 220-221; identification of reputationdetermining areas 112-113; operationalization of 100-105; overview 134-138;

recommendations 212-214; reputation measurement 121-125; reputation-building strategies 162-166; reputation-building strategy 119-120; scientific exploration of 216; stages of 110-125; stakeholder communication and 156-161, 157; stakeholders 140-151, 145-148; sustainability of 167-172; tasks for 134-135; value's importance in 110-111

family business values $8,64,107,174$; factors affecting 189-190

family businesses 3-4, 55; brands 59-60; classification of 53-55; core characteristics 137; definitions of 52 , 54, 55; employees 138; features of 55-59; image of 5-6; image of family 5; model 58; nature of 52-62; number of employees 138; overview 52-53; relational capital 66-72; reputation management 4 ; reputation of 5-6; stakeholders 112-114; statistical tools for data analysis 138-139; survey 138 ; values in $4,60,62-66,205$; on the verge of succession 53; weaknesses and limitations of $61-62$

family values 63, 181-182

Far Eastern Economic Review 39

Feldbaure-Durstmuller, B. 75

Fernandez, M. 64, 77

Fernandez, Z. 80

Fernandez-Gamez, M. 121

Fiat 56

Fiegener, M.K. 76

Fill, C. 31

financial institutions, expectations and values of $\mathbf{1 1 6}$

Fleming, Q. 57

focus/concentration principle 97, 99

Foltyn, D. 29

Fombrun, C.J. 2, 17, 21, 25, 38, 97, 98, 121

Forbes 56

Ford 56

Fortune AMAC2 ranking 121

Fortune magazine 39

Foss, C.B. 98

Freeman, R.E. 113

Frishkoff, P.A. 74

future research 220-221

Gallo, M.A. 80

GAP 81

Garberg, N 38

Garcia-Alvarez, E. 77

Gioia, D.A. 41

Glaser, B.G. 106

Gluszek, E. 38, 41 
Golata, K. 23

Gomez-Mejia, L.R. 74

good reputation 1, 2-3; benefits of 100 , 136, 165, 166, 168, 170, 211; building 5, 17, 40-41, 59, 65, 104, 161, 163, 209; capital and 68; and charisma of CEO 69, 71; communication activities 7 ; and company valuation 122 ; and competence 20 ; and crisis management 96; and customer satisfaction 96-97; determinants of 37 ; features of 40 ; influence of family business owner/ leader 104; in internatonal market 81; negative consequences 41 ; positive impact of 108; and staff recruitment 40; in stakeholders 36 ; threats to 101 ; values and 63, 66

goodwill 1, 20, 33, 122, 124,

188-189, 190, 205

Gornik-Durose, M. 72

Gotsi, M. 31

government, expectations and values of 116

Grant, R.M. 103

Gray, E.R. 17, 36

Griffin, J. 17

grounded theory 8, 106

group values 63

Grucza, B. 113

Grycan, Z. 56

Grzeszczyk, T. 113

Haidt, J. 67

Halikias, L. 31

Harris-Fombrun reputation quotient 39, 121

Hayward, M.L.A. 41

Heineken 56

Hewlett-Packard 56

hierarchical relations 112

Hilton 56

Hofstede, G. 29

Honey, G. 101

horizontal relationships 112

Howorth, C. 57

human capital 15, 35

IBM SPSS Statistics 24 software 138 identity 2, 22-23; definitions of 26; management 31,36 ; principle 97 , 99; reputation and 21-23

IKEA 56

image 2, 21, 22-23; of family businesses 5-6; as intangible asset

34 ; reputation and $31-37$

image management 36

individual values 63

intangible asset 34

intangible assets 1, 15, 20, 103-104

Intel Inside campaign 98

intellectual capital 15, 20, 122

intended image 36

interest groups 1,112

interested groups 112

interested parties 112

internationalization of family business 80-85, 83-84

interpretative-symbolical paradigm 27

investors $1,3,17,20,34,58,67,68$, 75, 113, 141-142, 145, 163, 170, 175, 190, 207, 212-213, 218, 219; and corporate reputation 114,121 , 170 ; expectations and values of 120 , 218; external 77

IS0 26000 standard 117

Jermier, J. 19, 121

Jeronimo Martins 81

Jezak 55

Jezak, J. 64

Joseph, C. 67

journalists 96

Kaiser-Mayer-Olkin test 146

Kalafut, P. 4

Kalafut, P.C. 40

Kaluzna, H. 75

Karaosmangolu, E. 27

Kets de Vries, M. 78

Kimhi, A. 78

Klimek, J. 62, 76

knowledge-based economy 15, 20, 33

Konecki, K. 106

Koral 56

Kos 121

Kotlar, J. 74

Kouzes, J. 17

Kovoor-Misra, S. 41

Kramer, R. 41

Kroeber-Riel, W. 32

Krys, R. 27-28

Kuttner, M. 75

Lafferty, B. 19, 121

leadership 98

Lego 56 


\section{Index}

Leroy Merlin 56

Levi Strauss 56

Levis 81

Lewandowska, A. 53, 77

life cycle of family businesss $57-58$

local and government administration $17,58,66,140,141,144,175$

local communities 58, 66, 96, 140, $144,175,181$; expectations and values of 116

Long, R.G. 74

Low, J. 4, 40

Lussier, R.L. 76

Mahon 96

Majchrzak, K. 2, 102, 107

management sciences 8

Manager IMagazine 39

market value 163,164

market value added (MVA) 122

Markwick, N. 31

Marriott 56

Marrynluk, O. 62

Mars 56

Mathews, K.M. 74

Mazur-Wierzbicka 74

McGuire 114

media 17, 36, 38, 41, 58, 66, 68-69, 71-72, 124, 140, 141-142, 144, 163, 175, 190, 207, 219

Melewar, T.C 27

Michelin 56

micro-family businesses 140

Mikula, B. 15

Miles, L. 96, 101

Miller, D. 78

Mokate 56

Moris, M.H. 76

multidimensional attitude 32

multigenerational family businesses 55

Nag, R. 41

neopositive-functionalist-system paradigm 27

network economy 15

new economy 15

Niehm, L.S. 72

Nieto, M.J. 80

node points 162-163, 207, 209

Nogalski, B. 29

one-person managementg model 102 organization 36 organizational culture 29

organizational identity 24

organizational issues 102

organizational success 216

owner, image of the owner $66-72$

owner-managers 71

owners: benefits of good reputation

168; declarations of 169, 169-170;

essence of reputation 168

paradox of family business 57

partners see business partners

Partnoya, F. 41

Pavelin, S. 121

Peksyk, M. 121

Penc, J. 33

personal relationships 112

personal values 63

Pfarrer, M.D 41

Pietruszka-Ortyl, A. 15

Piotr and Pawel 56

Polish Family Business Initiative 78

Pollock, T.G. 41

polymorphic model of corporate identity 31

Pont, C.G. 80

Popczyk, W. 64, 67

Poplawski 75

Porsche 56

Posner, B. 17

Post, J. 17

postmodernism 27

potentially family businesses 53

Potocka, A. 15

pressure groups 96

professionalization 215

public relations 4, 36, 40, 99, 104, 156, 208

public relations campaigns 209

rating agencies $71-72$

Ravazzolo, F. 17

Reger, R.K. 41

regional communities, expectations and values of 116

regulators 96

Reid, R.S. 74

relative design 101

reputation 1, 1-2, 22-23; assessment and 2 ; asset components 4 ; attributes of 19; awareness and 2; concept of 206; and corporate social responsibility 72-75; definitions of 
17-21, 18; enterprise management and 15-24; essence of 168; factors affecting 206-207, 218-219; in family businesses 4 ; of family businesses 5-6, 62-66, 72-75; identity and 2, 21-23; image and 2, 31-37; overview 15-16;

stakeholders 3 ; threats to $158-160$; trends 16-17; value of 211

reputation assessment criteria 208 reputation management 36 ; definition of 4; elements of 5; principles of 95-100 reputation measurement 121-125 reputation of family business:

internationalization and 80-85, 83-84; sucession issue and 75-80; threats to 101-102

reputational paradox 41

reputation-building 104, 190-212; barriers to 75 ; corporate social responsibility and 72-75; of family businesses 72-75; tasks for 98 reputation-building strategies $5,7-8$, 102, 119-120, 162-166, 190-203, 204, 209

reputation-determining areas, identification of 112-113

Reyes, F. 114

Rindova, T.G. 41

risks 219; financial 38, 98; identification of 163,212 ; prevention 162, 219; reputation loss 8, 101, 120, 200-202; and reputation-building strategies 162 ; response to 103; successors 77

Roleski 56

Rose, C. 121

rotated component matrix 149

Rydzak, W. 2

Safin, K. 66

Samsung 56, 85

Schreiber, E. 104

Schweizer, T. 17

scientism 106

self-presentation 220-221

sequence of events 101

services 98

Sever, J. 38

Shanker, M.C. 55

Shapiro, D. 41

shareholders 96; expectations and values of $\mathbf{1 1 5}$
Sharma, P. 76

signal filtering 100

single-generation family businesses 53

small- and medium-sized enterprises

(SMEs) 71

Smith, J. 80

Smith, K.T. 121

Smith, M. 121

social institutions, expectations and values of $\mathbf{1 1 6}$

social media 124,156

social partners 112

social responsibility 98

Soenen, G.B. 30

Solaris Bus 56

Somers' D. 139

Somervill, I. 97

Sonfield, M.C. 76

Spearman's rank correlation coefficient 139

Stachowicz, D. 27-28

stakeholder theory 74

stakeholders 3, 67, 79, 102, 207-208; communication with 114-119, 156-161, 157, 208-209, 217; dialogues with 114-119; expectations and values of $\mathbf{1 1 5}, \mathbf{2 1 8}$; external 71; in family businesses 112-114, 140-151; focusing on 112-114

Stanczak-Strumillo, K. 62

Stradomski, M. 76

strategic actors 112

strategic identity management models 31

Strauss, A.L. 106

Stuart, H. 31

succession 53, 63, 211, 219; and reputation of family businesses 75-80

successors: benefits of good reputation 168; declarations of $169,169-170$; essence of reputation 168

Sulkowski, L. 27, 53, 106

Sund, L.G. 76

suppliers 96; expectations and values of $\mathbf{1 1 5}$

sustainability of reputation 167-172, 211

Suvatjis, J. 31

Sveen, J. 80

Swinth, R.L. 81

Szczepanska-Woszczyna, K. 64 


\section{Index}

Sznajder, A. 32

Szwajca, D. 20, 102

Tapies, J. 64, 77

Thomsen, S. 121

threats to reputation 101-102

to be good 17

to be known 17

transparency principle 97, 99

unintended consequences of reputation 101

uniqueness of reputation 101

valuation 122,123

values: in family business reputation management 110-111; in family businesses 4 , 60, 62-66; of family businesses 205; of reputation 205; and reputation of family businesses 62-66, 209-211; reputationbuilding 66-72

Van Dijk, T.A 71

Van Riel, C. 17, 25, 67, 97

vertical relationships 112

Vinton, K.L. 81 vision 98

Walker, K. 19

Wal-Mart Stores 56

Wang, K. 121

Ward, A. 80

Wartick, S.L 96, 114

Wegrzyn, G. 20

Wesolowski, W.J 106

Whetten, D.A. 24

Wiecek-Janka, E. 53

Wilson, A.M. 31

Winnicka-Popczyk, A. 64

Wojcik, K. 124

Wood, E. 97

work environment 98

Z. Grycan 56

Zahra, S.A. 80

Zaleski, Z. 72

Zarebska, A. 27

Zavyalova, A. 41

Zbiegien-Maciag, L. 29

Ziaja 56

Zlotowska, G. 77 